
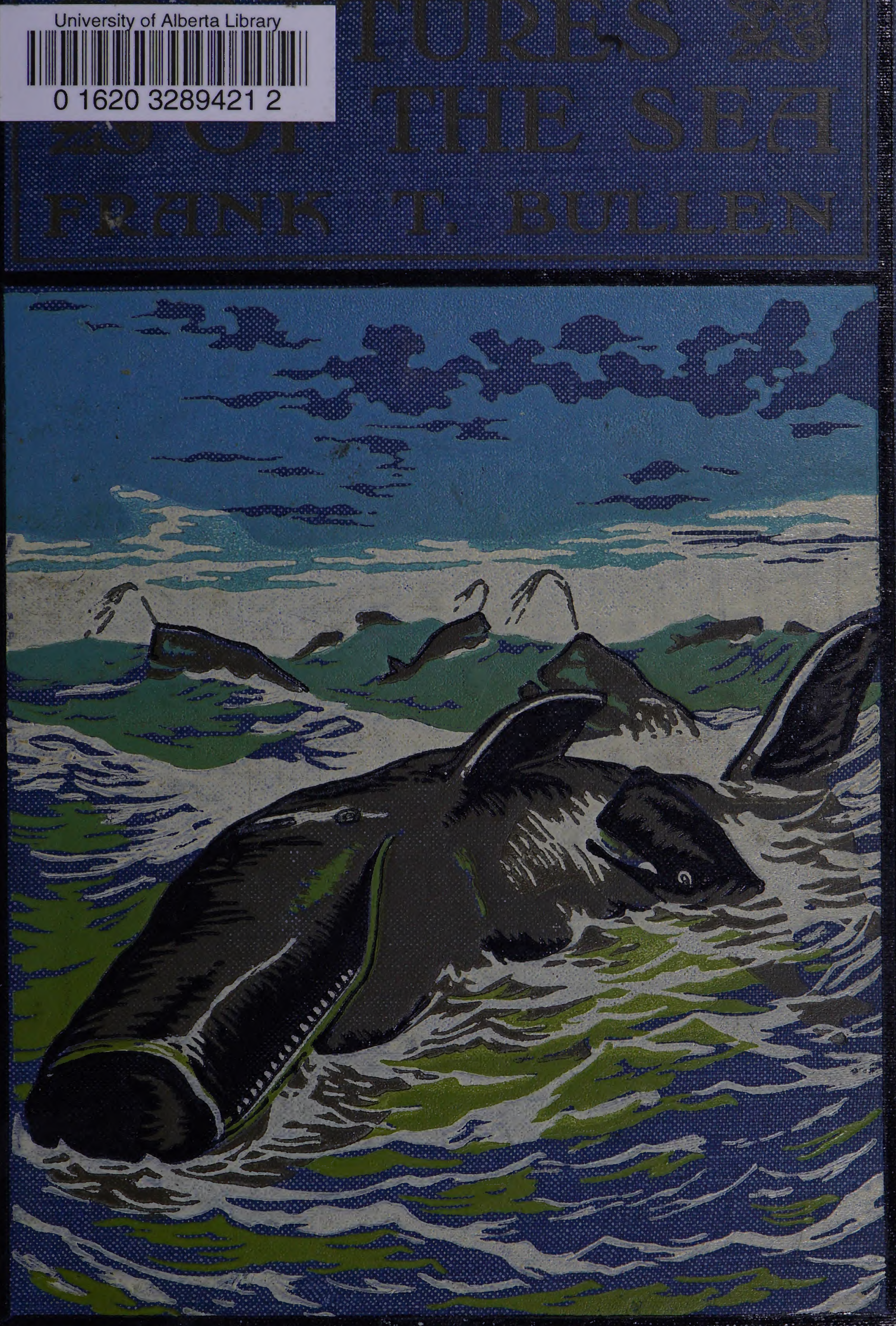


CREATURES OF THE SEA 

.46. 


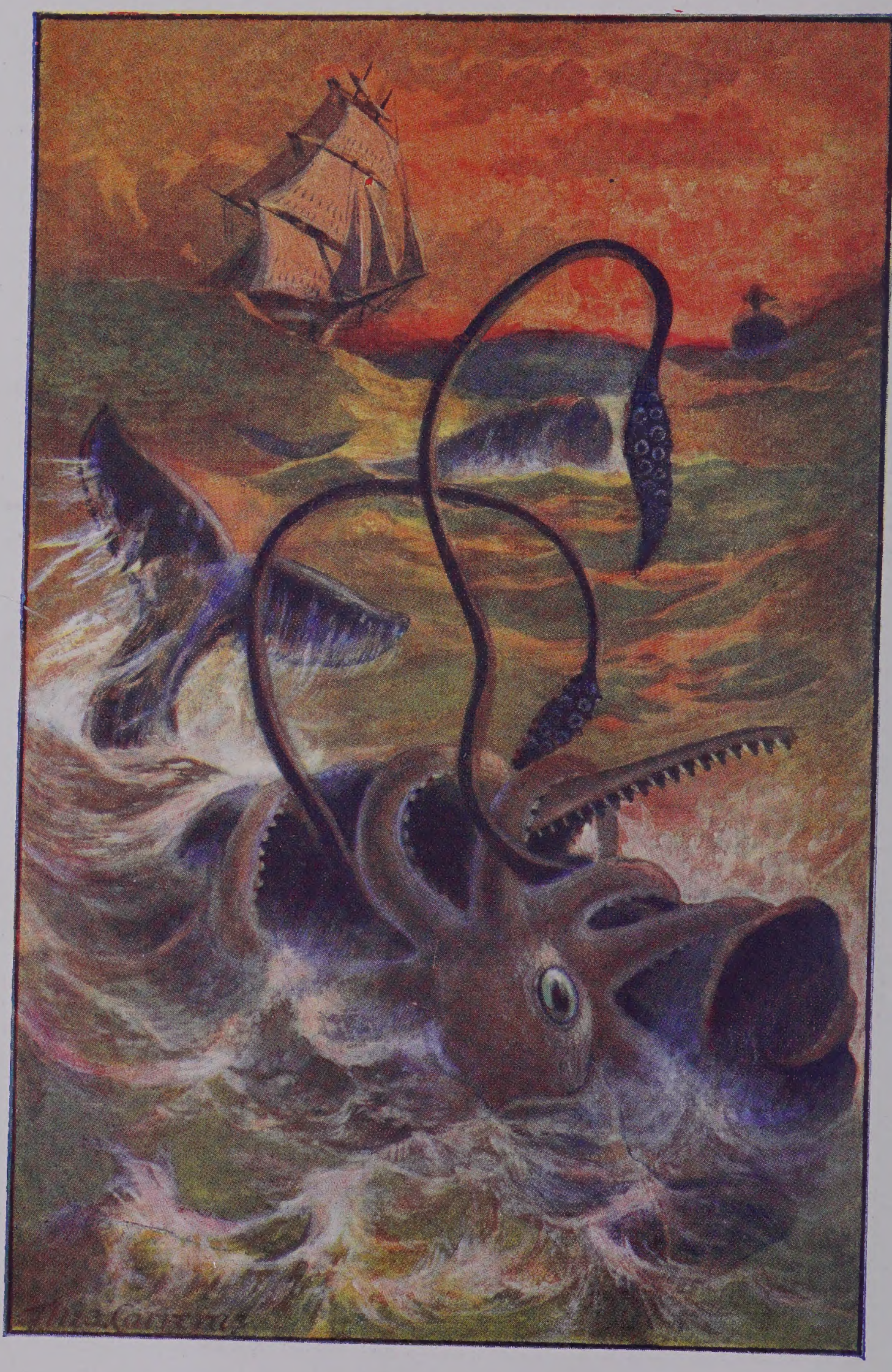

FIGHT BETWEEN A SPERM WHALE AND A GIANT SQUID. 


\section{CREATURES OF THE SEA}

BEING THE LIFE STORIES OF SOIME SEA BIRDS, BEASTS, AND FISHES

\section{By' \\ FRANK 'T. BULLEN, F.R.G.S.}

AUTHOR OF "THE CRUISE OF THE "CACHALOT," "WITH CHRIS'T AT SEA,' 'A SAILOR APOSTIE,' ETC. • .

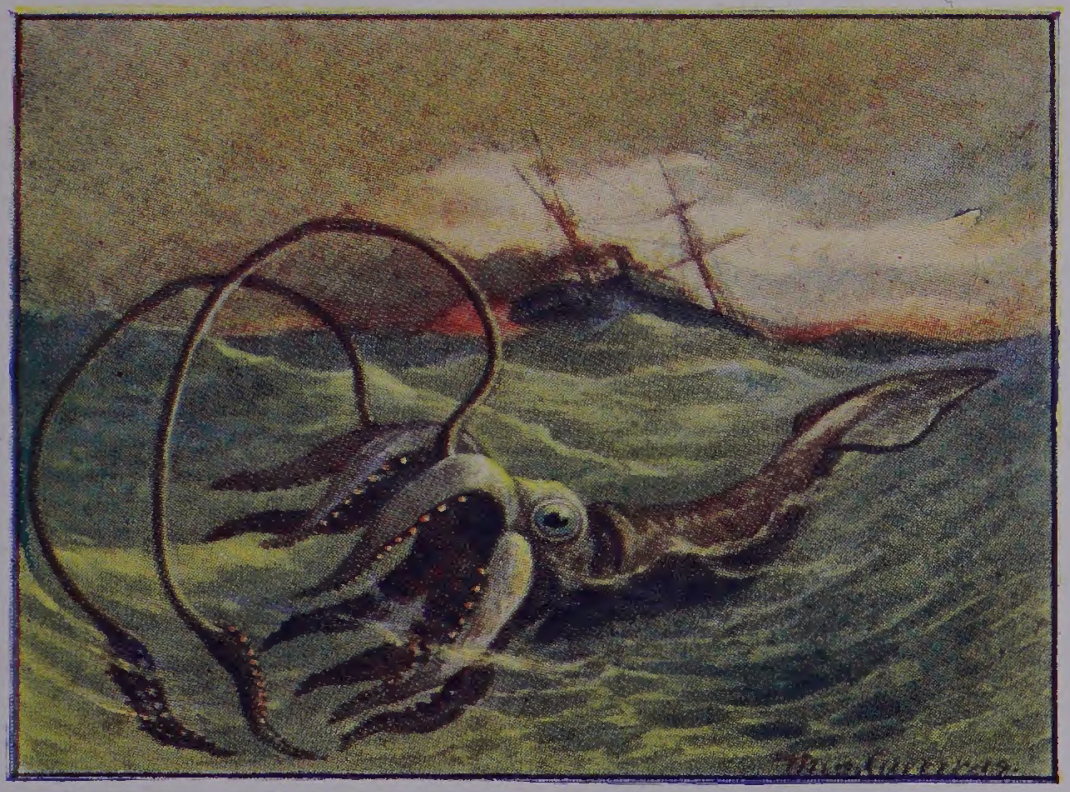

R.T.S., 4, Bouverie Street, London, E.C.4. 


\section{PREFACE}

$\bigcup^{\text {HETHER any book needs a Preface as well }}$ as an Introduction is a question that may fairly be debated. But I have ever had a kindness for Prefaces, have, from my earliest acquaintance with books, always read them carefully; and so, although the first part of this book that was written was the Introduction, when all else was finished I felt that I could not let it go forth to the world without a Preface as well.

There were several reasons why I should write a Preface, not the least of which was that I could now see how far my execution of a pleasant task had corresponded with my desires. Alas! Upon rereading that Introduction $I$ feel that $I$ have indeed fallen short of my ideal-that I have done very much less than bare justice to my marine friends, far less than I had hoped. But still, I do feel that in many instances I have been enabled to bring before my readers some first-hand glimpses into that intimate life of the sea which is so little known, and accounts of which may be sought for in vain in natural 
histories. Here I have great hopes that some measure of success has attended my sincere efforts to depict life in and upon the ocean as it has been personally known to me.

Another reason for writing this short Preface is that it enables me to call attention to the artistic and sympathetic work of Mr. Theo. Carreras, my artist coadjutor. The liberality of the Religious Tract Society has enabled us to give no less than forty of these really beautiful illustrations, and I cannot feel too grateful to them for having thus assisted me. For the making of those drawings has been a labour of love, Mr. Carreras having brought all his artistic knowledge to back up and reproduce my recollections of the attitudes of the various creatures, and the result is to me most gratifying. I feel confident that it will not be less so to my readers.

And so I leave my book in your hands, friendly reader, with pleasant remembrances of your kindness to me to buttress my hopes that this latest effort will meet with the same appreciation.

FRANK T. BULLEN. 


\section{CONTENTS}

CHAP.

PAGE

I. INTRODUCTION

1I. THE AUTOBIOGRAPHY OF A SPERM WHALE I 3

III. THE MYSTICETUS, OR RIGHT WHALE - 39

IV. THE HUMPBACK WHALE . . . . 5 I

V. THE RORQUALS • . . . . . 59

VI. SIRENIA $\quad . \quad . \quad . \quad 73$

VII. THE WALRUS, MORSE, OR SEA-HORSE - 77

VIII. THE SEA ELEPHANT • . . . . 83

IX. SEALS . . . . . . . 90

X. THE SHARK . • . . . . . 97

XI. THE TURTLE • . . . . . I I4

XII. THE CUTTLE-FISH OR SQUID • • . I27

XIII. DEEP-SEA CHIMARAS • . . . . I46

XIV. SEA-SERPENTS . . . . . . I65

XV. THE ALBACORE . . . . . . 182

XVI. THE BONITO . . . . . . 204 
4

\section{Contents}

CHAT.

XVII. THE FLYING-FISH $-\cdot 221$

XVIII. THE DOLPHIN . . . . . . 238

XIX. THE MACKEREL . . . . . 256

$\mathrm{XX}, \mathrm{COD} \cdot \quad . \quad . \quad . \quad . \quad 274$

XXI. THE HERRING . . . . . . $29 I$

XXII. THE BARRACOUTA . . . . . 3IO

XXII. THE ALBATROSS . . . . . 33 I

XXIV. CAPE PIGEONS AND WHALE BIRDS • 350

XXV. THE PETRELS . . . . . . 368

XXVI. BOOBIES AND PENGUINS . , , 386

XXVII. THE FRIGATE BIRD . : . . . 403

XXVIII. SEAWEED • . . . . . . 417 


\section{LIST OF ILLUSTRATIONS}

Fight between a Sperm Whale and a Giant SQuid Frontispices

A Sperm Whale Baby

SPERM Whales at DiNner . . . . . . . 20

The Cachalot's Fight for Power . . . . . 25

The Cachalot's Death Struggle . • . • . 35

A Right Whale and its Foes . . . . . . 44

A Mother Whale pursued by Sharks • • • . 52

HARPOONING BLACKFISH • • • • • • 7 I

The Haunts of The Walrus . . . . . . 80

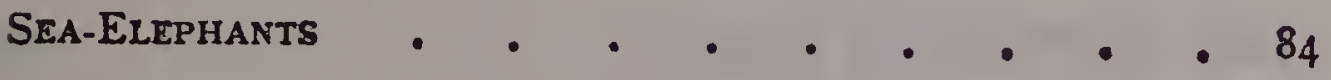

A Fur Seal Rookery . . . . . . . . 93

SOME Typical Sharks • • . . • • • 97

Harpooning a Slefping TURTLE. • • • . $~ I I 7$

AWaIting The TURTLE • . . • . . . 124

A Deep Sea Beast of Prey (Giant Cuttle-fish • 129 
Giant Souid and Common Loligo

Deep Sea Nightmares . . . . . . . . I6I

The 'Daedalus' Sea-Serpent, and its most probable Explanation . . . . . . . . . . 176

The Albacore's Narrow Escape. . . . • . Igo

Breeding Place of the Albacore . * . . . 202

A School of Bonito . . . . : . . . 208

A School of Flying-Fish attacked by Albacore • • 225

A Shark seizing a Dolphin . . . . . . 24I

Netting Mackerel. . . . . . . . 256

HoRSE MACKEREL AND GARFISH . . . . . . 273

Line Fishing for COD ON THE 'BAnks' . . . . 288

POLLOCK FEEDING ON THEIR YOUNG . . . . . 290

In the Herring Curing House . , , . , , 3OI

How the Whiting is Caught . . , . , . 305

BARRACOUTA • . . . . • . , , , 320

The Albatross • • • . . . . , 340

LEFT tO HIS OWN ReSOURCES • • • • • 349

WHALEBIRDS • • • • • • • • • 353

Strange Companions . . . . . . . 357 


\section{List of Illustrations}

Cape Pigeons

The Fulmar Petrel (Stinker) • • . . • 368

Stormy Petrel teaching ITS Young to FLy • • • 373

Stormy Petrels . . . . . . . . $\quad$ - 380

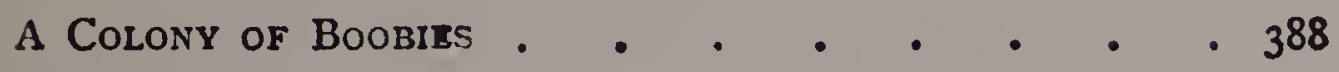

Penguins $\quad \cdot \quad \cdot \quad \cdot \quad \cdot \quad \cdot \quad \cdot \quad \cdot \quad \cdot \quad \cdot \quad \cdot 397$

The Frigate Bird at Work . . . • . . 410 




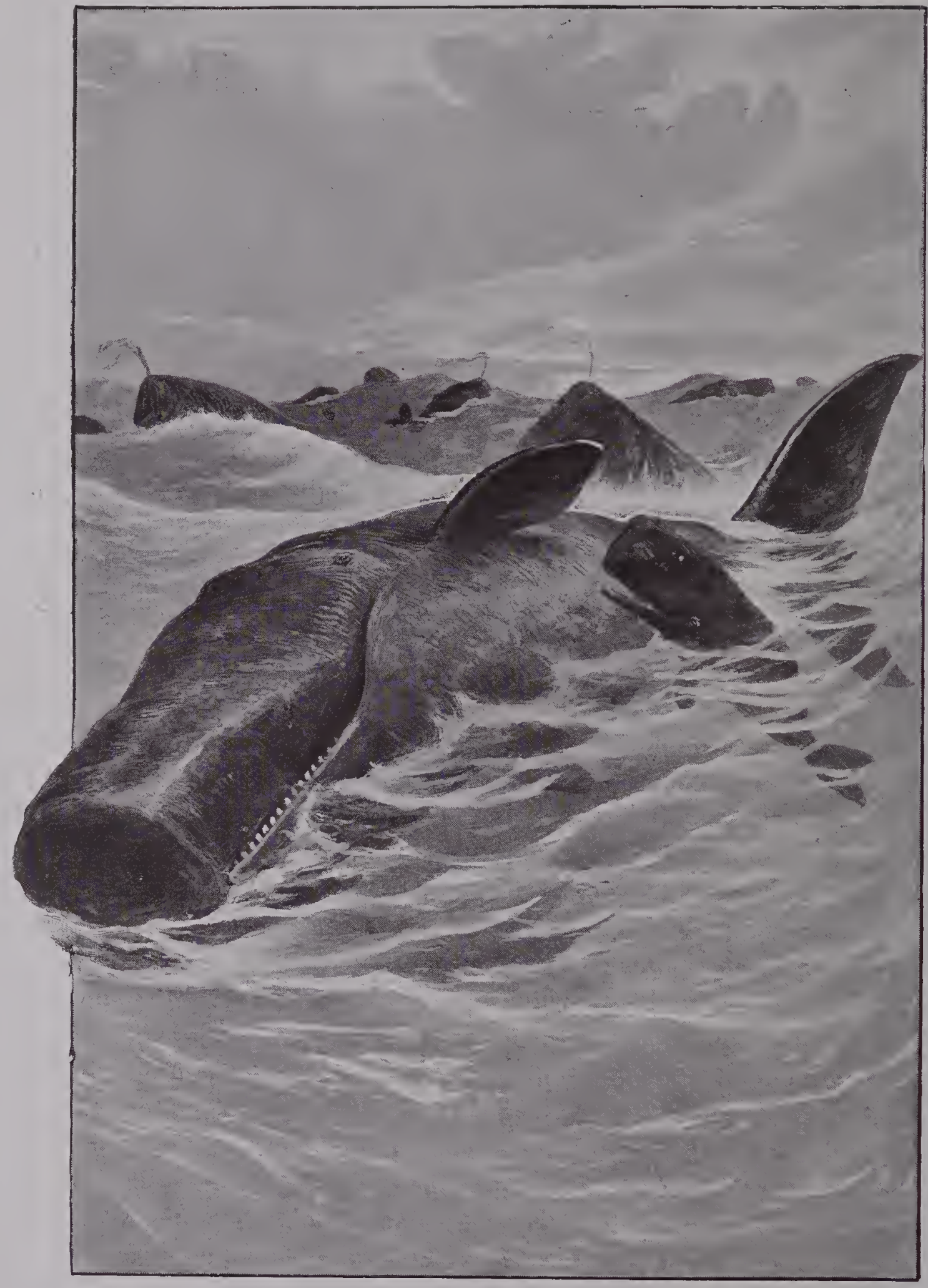

A SPERM WHALE BABY.

[To face $p .9$. 


\section{CREATURES OF THE SEA}

\section{CHAPTER I}

\section{INTRODUCTION}

7 HERE has of recent years grown up a very pleasant practice with certain writers, notably the lamented Richard Jefferies, the inimitable Kipling, and Ernest Thompson-Seton, not to go further in cataloguing names, of supplementing the standard works on Natural History with intimate personal details of the every-day lives of wild animals from the highest to the lowest, not excluding insects. I said pleasant practice, but would add profitable to the reader of whatever age, for I think no one except some dry-as-dust, blear-eyed professor, groping amid the dry bones of his museum all his life, would fail to agree that a story like Kipling's White Seal, for instance, must convey to the average reader, whether young or old, more retainable knowledge of the creatures it treats of than a whole weighty volume of dry facts, mostly in dead languages, even supposing it was read. Of course, the desideratum is that the information presented in this narrative form shall be correct, that where the imagination is called in to supply the 
absence of exact data it shall not be allowed to commit indefensible extravagances, and that the stories as a whole shall, if not stamped with the same hall-mark of genius as the White Seal, at least endeavour to be as readable in their degree.

With this object before my eyes, I now essay a series of lives of the Deep-Sea People based very largely upon personal observation, buttressed by scientific facts and decorated by imagination. I well know how ambitious the task is, but I feel that I have some small qualifications for the work, and I know too how much room there is for a book of the kind. A minor difficulty confronts me at the outset. In justice the place of honour at the commencement should-I felt, must-be given to the undoubted Monarch of the Deep, the stupendous Whale. But I have written so much, so exhaustively about him (as a ship is 'she' to sailors, so a whale is 'he' to whalers), that it must be impossible to avoid some repetition (for which I trust I shall be forgiven) of what I have published before. And it would naturally appear as if I had deliberately chosen to place the Whales first because of my personal predilection for their gigantic company, and more extended acquaintance with them as regards their every-day life. But that is not so. I would gladly put a much smaller denizen of the deep sea forward first if I might with propriety do so. However, I feel that to be out of the question, so the Whale comes first.

Again, I beg to observe that this series of lifehistories will possess no orderly sequence of species or genera. I intend to keep mammals, fish, and birds, each in a section of their own, but apart from that, I wish to keep the work as unlike an orthodox natural history as it is possible to make it. Of necessity, 
these will be selected lives, since there are so many species of Deep-Sea Folk of which man, by reason of his limitations, can know practically nothing. But I do hope to include all the fauna of the sea likely to make interesting and popular studies-no, not studies. I want to dissociate the idea of study from the book altogether. If it smells of the lamp I shall be greatly disappointed, and so will my readers. It should read like a series of intimate biographies of tried and trusted friends, whose lives, though passed on a different plane from ours, are no less full of interest.

A high and solid wall of division separates us from the full fellowship with the lower animals which many of us feel would add a new zest to life. Now and then it gets low and thin, as in the case of the dog, the horse, the elephant, the cat; but even with these domestic friends there always meets us the baffling barrier, preventing the contact of our minds with what fills the same function in the animal. And if this is so in regard to those closely associated creatures, how much more is it in regard to the wild ones, and how immeasurably greater in the case of those interesting beings of whom we only catch fleeting glimpses as it were. Here imagination aided by experience is the only interpreter. It may mistranslate, it may fail to understand many things at all, but on the other hand it may-it has, it often does-hit upon the exact truth as to the inner lives of its subjects, at any rate, in far greater measure than any statistical compilation can ever do.

To conclude this brief introduction, let me say that in some cases I feel it will be preferable to make the sketch an apparent autobiography as it were-to let the creature written about tell his own story in our language, but from his point of view. This, I feel, would hardly be appropriate to all the life-histories 
of the sea-folk, but in some cases it will be peculiarly so. Notably among the mammalia and other amphibia. And now I feel that it would be injudicious on my part, as well as somewhat priggish, to spend more time in saying what I intend to do. Far better go ahead and do it. 


\section{CHAPTER II}

\section{THE AUTOBIOGRAPHY OF A SPERM WHALE}

$M^{\mathrm{Y}}$

earliest recollections are rather hazy, but principally centre themselves around pleasant sensations. I was born, as nearly as I can remember, at high noon in the Indian Ocean near the Equator. You must excuse me from being more exact, for while we whales know the oceans down to a depth of five hundred fathoms from North to South within the frigid zones, and all the watery world around, we do not pretend to the scrupulous accuracy with regard to exact position that humans do. Why should we? We always know where we are, we never miss one another, and although we keep no log-books we never forget anything that we ought to remember.

So to come back to my birthplace, it was, as I have said, in the Indian Ocean near the Line, and my first feeling was, 'How pleasant everything is!' The sea was like warm milk, the softest, most delicious cradle that ever babe was rocked in. Overhead, the glorious sun like a globe of molten fire that was bursting its bounds on every part of its rim, poured down a flood of life-giving heat. Not a cloud in the stainless blue, not a fleck of foam on the peaceful waters, only great 


\section{I4 Autobiography of a Sperm Whale}

glowing breadths of colour ever changing in obedience to some mysterious law. I lay, happiest of the happy, by my mother's side, my blunt nose protruding from the water about a foot, the teat in the angle of my jaw, in which the immature teeth were just sprouting, and the rich milk streaming sweetly down my throat quite unmixed with any sea-water. You see, we have a most exquisite contrivance in our gullets, which without any effort on our parts, takes in the food and shuts out the sea, even at enormous depths. But just how it does it I cannot explain, nor do I think that anybody can. I looked a queer little creature, with my head, the biggest part of me, like a tarlpole's, and my long thin lower jaw sticking out in rront of me almost as if a big splinter had run into my face and remained there. But my mother did not think so; she was very proud of me, and we both lay upon our beautiful couch, supremely happy.

All around us lay the rest of the school, thirty or forty cows, eight or ten young bulls, and father. Ah, never shall I forget when I saw him first. He was going round the family to see that all was well, as he did some six times a day, and he passed quite close to where I nestled at my mother's side. He was one of the mightiest of our mighty race, with a head like a promontory and a length of over seventy feet. And as he surged slowly up behind me on the surface of the quiet sea, I saw the whole of him clearly and trembled. (You must understand that we can only see behind us owing to the position of our eyes, which are placed a little below where the shoulders are in a man and almost in the middle of the body's breadth.) He just glanced at me as he glided by, a glance as it seemed to me of perfect satisfaction. My mother quivered with delight, as, sheering in towards her, he touched his forehead to 


\section{Pleasant Days at Home I5}

hers, graciously, as became a monarch towards his adoring consort, with whom he was well pleased.

For many days we remained in this mid-ocean solitude, chosen by our wise ruler as being where none of the hateful monsters of man's making ever came, a place not too far from rich plateaux not too deep, whose intricacies swarmed with our proper food, where the sea-streams ran warmly and the sun rose and set continually with never a cloud, a place where we alone of all the sea-folk had no foes to fear. This proud pre-eminence above all our fellows had not long been ours. In our hasteless chronology it seemed but a short time past since in every part of the sea we were liable to pursuit, harassing wounds, and death at the hands of men. Alone among the tribes of earth and air and sea we feared them, for we knew by bitter experience that our utmost rage, strength, and courage availed nothing against these feeble ones, who nevertheless were so wise that they were bound to overcome us. True, we did them terrible damage on occasions, and some of our warriors, notably the head of my family, had invariably come out of conflicts with the earthpeople without deadly injury, although bearing all over their vast body-surfaces wide white scars where the cruel wounds dealt them by men had healed. And each of them had a long roll of victories to his credit. Yet this did not make them tyrannous or over-bearing, it but added to their wisdom and ability to command the younger generations.

Now I am not so arrogant as to suggest that all this knowledge was mine as soon as I was born, I do but tell you these things as a sort of introduction to my family, of which I am mightily proud, yet not more so I think than they deserve. No, like all young creatures, for the early days of my life I was content 


\section{I6 Autobiography of a Sperm Whale}

to be alive and full of joy. Everything was new, everything was entirely delightful. I was very soon weaned, for among our people, the Sperm Whales, there does not exist that intensity of maternal affection which characterises the other kinds of whale, with only one exception. We really do not need it, for food is easy to obtain, and of a nature entirely fitted for a mere baby to eat. So that when I was less than a month old I had taken my place in the school as one of its ordinary members, and my early relations with my mother were entirely forgotten-in fact I knew no difference between her and any other member of the school or family. But during all that period I had been learning by closest imitation, as well as by yielding to my strange inward promptings impelling me to do that which I had never done before, in emulation of the feats I saw being performed by those around me, and when I became independent I was, although quite an insignificant member of the school, fully capable of doing all that they did in respect of swimming, diving and obtaining food.

I am now getting old, the waves and storms of half a century have rolled and thundered over my head, but vividly as on that first day do I remember when by my mother's side closely following her every movement I sank into the cool, translucent, and darkling depths for the first time. I shrank closely in to my mother's bosom as we left the warm sunshine in which we had been basking. I noticed with youthful wonder and admiration the stately graceful way in which my mother arched her back, lowered her head and elevated the broad fans of her tail into the air as she descended, and then all else was swallowed up in amazement. Slowly we sank through the increasing coolness of the sea, dimmer and dimmer grew the light from above, until, 


\section{Earn Experience}

after what seemed a day, but could only have been a few minutes, we stopped our descent and began to move horizontally.

At first I was dreadfully distressed. I felt as if I was being squeezed flat, I wanted to breathe, but I found that my nostril was as securely sealed as if it was never to be opened again, certainly I could not open it. My lower jaw hung down, leaving my mouth wide open, and presently a delicious quivering morsel went gliding down my throat, giving me a most exquisite feeling of satisfaction. The gloom which had so troubled me at first gave way to a tender, greenish light shed abroad by myriads of shining things that glowed and faded as they floated about apparently without any will of their own. The cold, too, which at first had felt unbearable, chilling my blood and making it feel as if it was thickening so much that it could not flow, became less unpleasant. And presently, tiny as I was, I realised that this was my proper realm, that here our people were supreme, and that of all the myriads of diverse creatures in the sea we were the undoubted heads and leaders. All other sea-citizens but ourselves pre" ed upon and were preyed upon by other denizens of the deep, we alone took toll where we would, ourselves secure from all assault by any of the sea-folk. It was a high and elevating thought to feel oneself a lineal descendant of such a mighty and ancient line of ocean royalty.

All around me glided in utter silence amid the varying gleams, like vast shadows, the members of the school. Occasionally in hasteless, dignified fashion one would rise perpendicularly with some palely glowing mass between his jaws, and reversing his position, let the great saw of his lower mandible divide whatever it was he held into sizeable fragments 


\section{I8 Autobiography of a Sperm Whale}

for swallowing. These pieces were upon the same colossal scale as himself, and slipped down his gullet with an easy celerity that was pleasant to see. No one was selfish. The prey of one was the prey of all, and a certain gigantic courtesy prevented any individual from appropriating more than his actual share. But suddenly into the midst of these mysterious delights there thrust itself an imperative command to seek air. We can and do remain in the depths for as much as one hour, according to our size, but the length of time we stay down is always carefully calculated according to the need of the youngest member of the party. Ah! the swift rush upward, impelled seemingly by the whole weight of the ocean beneath. Ah! the blissful emergence into brightness most dazzling, and the simultaneous opening of all spiracles. Oh! the sweet rush of heaven's air through the quivering nostril into the labouring lungs. Indeed, it is good to endure privation of air for a season if only to realise how lavish of His choicest gifts is the Power that sways us all.

Then to lie basking again, feeling that sweet breath, the true essence of life, coursing through every artery, tingling in every muscle, making one feel as if nothing but action, swift, tremendous, exhausting, could satisfy the exuberant needs of the body. Oh! the delight of just being alive. Is it any wonder that even our majestic chief, yielding to the overmastering needs of such an influx of life, suddenly forgot his dignity, rushed like a tidal wave along the glowing surface of the ocean, and hurled his whole vast bulk towards the sky by the exercise of a force beyond calculation. After that one stupendous exhibition of power all lay in almost utter quiet, content so to lie. The sun went down, the moon rose up and the pleasant 
stars peeped out from the purple curtain of the night. No ripple of wave or querulous wail of wind disturbed the mid-sea quiet. Even the deep sigh of a waking whale but punctuated the soft stillness of the restful scene. All Nature was at ease around us, and above as below there was perfect peace.

The foregoing was just a typical evening as I remember it during my babyhood. But one morning there was communicated to all the family by that subtle interchange of thought, independent of speech, which we possess, the chief's order to proceed northward, following him. No one so much as thought of questioning his authority. $\mathrm{He}$ was our law and its only exponent. As well have questioned our ability to obey as his right to command. So as the great sun flooded the horizon with golden flame as if overflowing, we formed into ranks, and at a uniform speed of about six miles an hour, departed from that spot of ocean where I first knew life. I had no sentimental regrets, the whole wide sea was my home. Nay, more; I felt an absorbing desire to know more of this apparently illimitable realm of waters which had given me a place of birth in one of its tiniest eddies. So I gambolled gaily along in the wake of the young bulls of the school, restraining with difficulty my desire to leap after the manner of the chief, and revelling in the cool depths to which we periodically descended in search of food. When I come to think of it with the calmness that befits my age, I feel impelled to assert that in those days I had but two overmastering desires, the desire to eat, and the desire to dissipate the abundant strength that my eating gave me. But withal, I knew how to obey, or rather shall I say, I knew not how to disobey the guidance of my leader. Like all young things I felt independent 


\section{Autobiography of a Sperm Whale}

promptings to strike out a way of my own, but one glance at him quenched all such aspirations and made me feel how good it was to be permitted to follow so great a guide.

Very pleasantly passed a space of six days and then a whole wide area of new pleasures met my delighted senses. Whither we were bound I did not know, but now I can tell you that we made the Bab-elMandeb, no gate of tears to me, but a veritable portal of joy. During that short passage, so rich in life are the tepid Indian Seas, even my small body had become quite encrusted with parasitical growths, barnacles and moss and tiny limpets. They worried my tender skin, they fretted me beyond bearing, and so, when I saw the jagged surfaces of coral at the gate of the Red Sea, I rushed, as did my fellows, to chafe my irritated body along those gratefully corrugated summits of the edifices below. Ah! another joy ; to drag oneself luxuriously over those myriad needlepoints of coral, every touch sending a thrill of delight from fluke-edge to spiracle-yes, indeed, it was worth all the miserable days of annoyance preceding it to know the sweetness of the relief.

And then the food. Here was found in fullest abundance all that the sea had to offer us. Massy shoals of lazy fish that, needing no inducement, just swam serenely down the gaping caverns of our jaws, cuttles of medium size but soft and sapid, that without any attempt at resistance allowed themselves to drift gelatinously into the warm haven of our stomachs. Ah! the Red Sea is a good place. Yet one serious drawback we all found. By reason of our bulk (I may say 'our' now I have attained perhaps the maximum size allotted to the Sperm Whale) we were often compelled to give the shallow shores a wide berth. But 


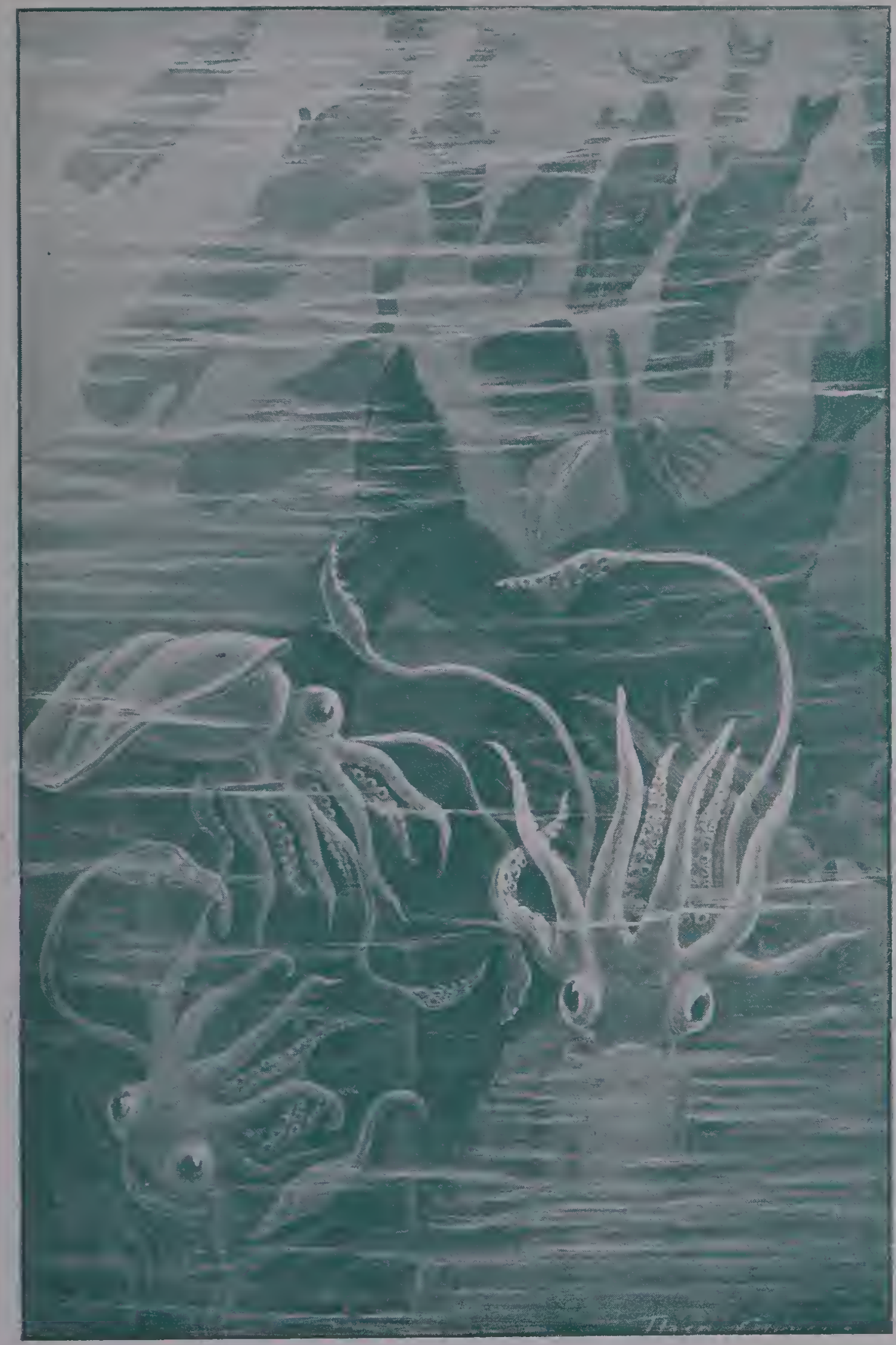





\section{Happy Days}

in the mid-sea there was no peace. From the incessant churning up and befouling of the water there was no escape. Methinks that all the land-driven monsters using the sea as their highway did concentrate there. And when I saw one of them strike the black scarp of Jebel Zukur and fall apart in shards I was gravely content. Why should all the sea be given up to the business or pleasure of those who rule all the land ? thought I, nor did I give one jot of mental effort to the problem of why it was that we, the seed-royal of the sea, were now no longer hunted by men. Like most of my fellows, I was all-content to take the good as it came, never to anticipate evil unless compelled by instinctive prescience, but to live and enjoy the passing day, taking no thought for what might be coming.

Here in this pleasant sea we remained for many months. Nought of harm, of annoyance came near us so long as we kept to east or west of a well-defined line drawn down the middle of the sea. We lay and luxuriated in the rich sea-pastures within the sheltering reef-barriers, fearing nothing and fattening upon the never-failing stores of rich food around us. We had but to lie still, open wide our mouths and let them fill. What wonder that we all grew fat and slothful, all, that is, who had attained their full growth. The other youngsters and myself grew amazingly, for not only did we eat all that we felt inclined to, but like all young things, rejoicing in our perfect life and full freedom, we gambolled, we raced, and did all that the abundant vitality within us prompted us to do, and there were none to say us nay. And so the happy days passed, none taking count of them, all too intent upon enjoyment of the present to think of the future, until one morning our great chief gave the gathering signal, 


\section{Autobiography of a Sperm Whale}

and was instantly obeyed. For with us there is no half-hearted or unwilling obedience. We choose our chiefs for their ruling qualities, and having chosen them it never occurs to us to disobey them or grumble at their orders. We know that they are fit to rule us, and we delight to obey. And when they are, by reason of advancing age or sickness or any infirmity, unfit to maintain their proud position any longer, we depose them unhesitatingly. We know we must be led, must have a chief, but we know that he must be best of the very best. Nor can he hold his position one day after he has fallen from our high standard.

In a close compact body, we left the pleasant purlieus of the Red Sea, and without deviating from our direct course, except to clear Sokotra, we made our way southward. Now I began to feel the benefit of our long stay in the abundant waters we had just quitted. Because here there was almost nothing for us to eat. True, as we passed through the blue depths in stately ranks an occasional shoal of fish would swim down our gaping throats, or a passing school of porpoises find permanent shelter in the vast maws of our elders. But these were incidental only. Nothing like the rich banqueting day after day, which had been our lot in the teeming sea behind us. But if we could feast when occasion offered, we could also fast when need arose. And need was laid upon us now. None but our chief knew whither we went, yet we followed him unfalteringly through those almost barren seas; barren, that is, so far as we were concerned.

Without haste, yet resting not day nor night, we pursued our journey southward through the mighty silences of the sea. Once, and only once, did we see anything to give us pause, and that was, as the water 


\section{Meet Man}

began to chill, when we met one of those mighty fabrics made by men and driven by fire across the ocean. We had been so long immune from pursuit, or indeed interference of any kind, that we took little heed of her except just to avoid her great onward rush, and the deadly swirl of her tail. Full of curiosity to see what this wonderful surface-monster might be, I rose behind it, and putting forth all my vigour swam after it to get a good view of it, when suddenly I heard a curious noise almost like the sound we make on a calm day when, lying upon the surface, we strike the water with our tails, and immediately I felt a burning, stinging pain run through me. I swerved in my course, and sought my companions, all of whom as I joined them put on their utmost speed in our original direction. For a time it seemed as if they avoided me, but, gradually, as the healing of the sea exercised its benignant effect upon the place in my side where I felt the pain, they closed in upon me again and I was no longer shunned.

Later, as we slowed down, our great chief deigned to halt near me and tell me what had really happened. He said that idle men and women (how I wondered what they were!) on board of these land-monsters or ships, possessing deadly things able to kill a long way off, did not hesitate to try and deprive of life, just for amusement, any of the sea-folk they saw. At which I wondered very much; for the earliest knowledge I absorbed was, never to kill but for food, and the news that there were creatures who killed for amusementfor pleasure-was very terrible to me.

However, although the memory of that encounter has never left me, my wound healed so rapidly that I never once faltered in our southward rush, feeling stronger and more fit every day, as the good sea gave 


\section{Autobiography of a Sperm Whale}

me of its strength, and the long feasting in the Red Sea came to its predestined and proper effect. The waters around me cooled and brought hunger-fierce, gnawing hunger. Yet there was little or nothing to eat. Our speed increased; without faltering or straggling we held steadily on, until one day, following our chief, we settled down, down, down. Deeper than ever I had dreamed of we went until, skirting the black bases of a mighty mountain range, we found our prey. Hundreds upon hundreds of enormous cuttle-fish, helplessly, slimily crawling about on the rocky floor or clinging with their myriad tentacles to the pillars of the earth, as with their huge eyes they saw us approaching. There was no escape for them. Alone among the inhabitants of the deep seas, we were their masters and they our legitimate prey.

We fell upon them in a body, and tore them limb from limb, feeling exquisite satistaction as the quivering succulent morsels glided down into our craving stomachs. I had devoured one huge fellow whose head had been bitten off by a big bull close to me, and was almost satisfied. Not quite, though; and with fresh ardour I flung myself into the fray, seizing a vast cuttle by the middle. He writhed round and enwrapped me with his far-reaching arms so that I could not get my mouth open. But my tail was free, and exerting all my strength I rose through the murky water dragging him with me. Fortunately, he had not had time to anchor himself to one of the rock bases. We reached the surface in a welter of foam, and there by my side was the chief, who, ranging up closely, seized some outlying tentacles of my prize, causing him to unclasp those that bound my jaw, and next moment the strong salt air of the sky was sending thrills of renewed life through my body. 


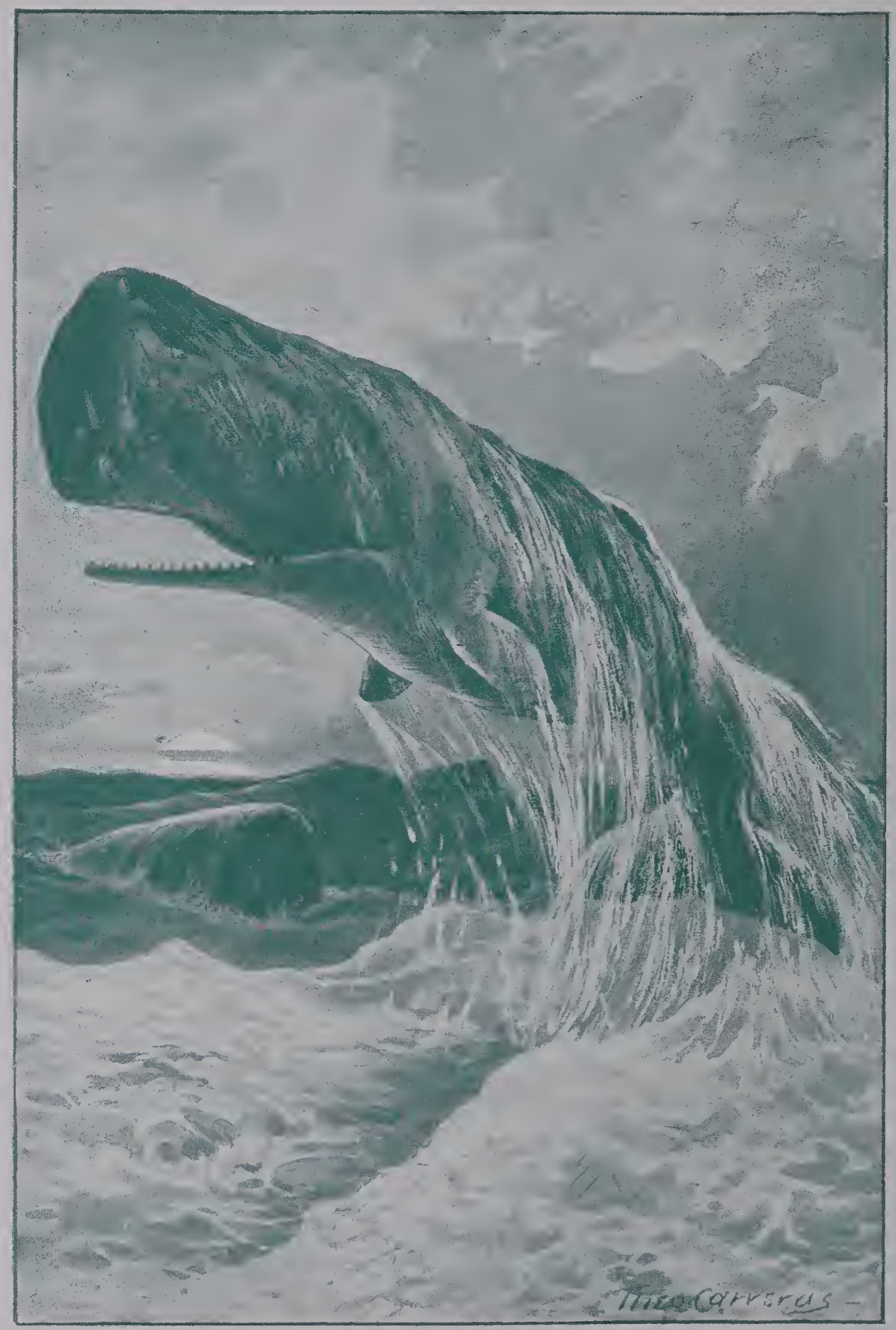

THE CACHALOT'S FIGHT FOR POIVER.

[To face p. 25. 


\section{Feeling Power}

Many dangerous crises have been encountered by me since then, but in none of them have I felt so near my end as on that occasion. Had it not been for my chief, I must have been drowned. I, the child of the deep sea, born to sport with the wild waves in their utmost fury, or sink far beneath them into the darksome profundities of ocean caverns-I should have been drowned! But I was not, and when in the sweet moonlight all our company foregathered on the surface, full fed, to lie in peace, lulled by the gentle rocking of the wavelets, I no longer regretted the peaceful tepid waters of the Red Sea. I had learned the delights of struggle and conquest. And I had been noticed by the chief !

Thenceforward I grew with amazing rapidity. I felt the gigantic power twisting the cable-like sinews of my flukes, knitting the columnar masses of my vertebræ, and piling up the cushions of muscle around my bones. A great joy filled me. I needed an outlet for it. To show what I could do, to hurl myself vengefully into the closely packed mass of advancing enemies, to lead the ranks of my fellows. ... Why, oh why, was all the accumulated wisdom of my thousands of ancestors surging in my brain, but to impel me to great deeds? And here, frantically, I hurled myself out of the sea thirty feet into the air, unable longer to control the raging forces within. When I fell back into the foaming vortex beneath, I was relieved, yet still with that sense of superiority over all living things surging within me. Perhaps it was the bracing effect of that chill sea. For we were now well south, on the outskirts of the beautiful isles of New Zealand, and every nerve in our bodies was strung tense with the springing of new life. Day broke and showed us the towering precipices of the South Island, against which 


\section{Autobiography of a Sperm Whale}

the monstrous rollers of the Southern Ocean hurled themselves vainly, retiring sullenly in clouds of spray and leagues of foam. It was a place of strife farthest removed from the languorous peace of our last restingplace that one could possibly imagine, yet inexpressibly grateful to me, who felt in all my members the need for vigorous action. This stern sea, those chill winds that howled over the whitening expanse of waters, sent the life bounding through my arteries, and I felt myself growing with abnormal rapidity, longing to test my strength, eager to fight.

Up out of the boiling foam there sprang a mighty mountain top, a pinnacle of rock that, reaching down into the darkening depths of that stern ocean, soared into the air as far again. And around it we circled feeding, for here food was even more abundant than within the Bab-el-Mandeb, my only standard of comparison. The storm raged higher and higher, the great waves hurled themselves headlong from their worldencircling journey against the mountain base and whitened its summit with spray, but still, all unheeding their strife, we made our rounds feeding, ever feeding. For we had only to sink a few yards to be in profoundest peace, no tumult of wind and sea affected us, except favourably, in that the agitation of the whole oceanic mass in these comparatively shallow waters stirred up the creatures upon which we fed and made them easier to obtain. Gradually it dawned upon me that our ranks were being augmented by many strangers. Whales I had certainly never seen before rubbed shoulders with me, but communicated no sign. Until when the next morning broke bleakly and cheerless over the foaming surface of the straits there were hundreds of our kind gathered, as if at some prearranged rendezyous for some definite purpose. I 


\section{Mystery and Added Prowess 27}

felt a great pride at being one of this mighty concourse, this assemblage of the mightiest creatures living, and I had some dim idea that maybe I might distinguish myself in some manner among them ; for I was now getting well grown, though far behind our noble chief in his gigantic majesty.

It was a premonition full of truth, for on the third day after our arrival while in company with some hundreds of my fellows I lay basking in the clear sunshine, the warning signal passed through me, telling of terrible danger very near. How it is communicated I cannot tell you ; neither by speech nor sound of any kind are we apprised of the presence of an enemy, but in every fibre of our bodies we suddenly feel that danger is near. Only we do not know from whence it is coming. We are intensely on the alert, but that is all. I lay like most of my fellows upon the shining sea surface, my columnar head half out of the water, my body slightly arched and my tail quiveringly playing from side to side as if seeking to test the vibrations of the water. Suddenly an unfamiliar tremor ran through me (I heard nothing because with us hearing is almost a lost sense) and immediately I felt a sharp stinging pain shoot through my right side. Filled with rage as well as alarm, I sprang forward, feeling as I did a drag at the wound in my side. Instinctively I dived, turning a somersault beneath the water, and coming up with a furious rush about twenty yards astern of my former position. As I did so, I caught a glimpse of a strange white monster, long and narrow, with two slender legs on each side, and throwing my tail high, delivered a blow at it with all my force. I felt my stroke take effect, saw as I came to the surface again a quantity of strange fragments floating, but beyond all I felt the smarting, 


\section{Autobiography of a Sperm Whale}

burn11.g pain of my wound, and without seeking further revenge, sank down, down, into the cool depths where I knew no enemy could ever come.

My fellows were all scattered far and wide; all cohesion or discipline seemed to have ended. What, then, could this dreadful calamity mean ? Was there an enemy before which even our splendid leader trembled and fled ? And I felt full of fear and wonder as the dread possibilities of a supremely powerful foe having overtaken us surged through my brain. I remained down to the full limit of my endurance, seeing nothing of any of my companions during the time. But when I reached the surface again, I felt the rallying signal vibrating through my body, and hurrying in the indicated direction soon rejoined the school. Then I learned that the strange monster I had destroyed was a boat with men in it, who were armed with terrible weapons, compared to which our jaws and flukes were but clumsy and almost useless. They had wantonly attacked us for some reason of their own, and had succeeded in slaying two of our number, who, paralysed with alarm at the sudden onslaught, had made but a poor defence, and had fallen comparatively easy victims. Me the great chief singled out for high honours. He told me that I had begun well; that having once realised my own power, and been successful in repelling this savage attack, I should be far more formidable to man than any whale could be who had never been assailed. For my wound was after all but a trifle, only a long trailing thing behind it made it gall me. My chief, however, advised me to take no heed of it. It would soon cease to annoy me, for either the tooth imbedded in my blubber would be dragged out by the trailing weight behind, or the weight would drop off and leave 


\section{A Land of Ice}

the weapon buried in my body, when the healing sea would soon close up the wound.

Then, feeling that such a neighbourhood was unpleasant to remain in, our chief led us farther south, to where a group of mountains just raised their heads from the tremendous depths to a little above the surface. Here, he said, he had never known man come even in the days when few haunts of our people were secure. Yet here we had almost all lost our lives through a singular misfortune which befell us. We had entered a little bay scooped out of one of the mountain-sides, with a very narrow neck, not much larger than would admit one of us at a time. At the entrance it was shallow, but within it widened and deepened so much that it was an ideal place to rest in, while from the surface on either side the steep walls of cliff rose sheer for a great height. And it was literally crawling with huge cuttles, our natural and greatly-loved food.

Here we were feeding in perfect content, and I had almost forgotten my recent adventure, when suddenly a chill struck through my very marrow; I felt as if my vital forces were about to cease their duties. We all felt it at the same time-that dread cold which is the horror of the Sperm Whale, and makes him avoid, as if it were a plague-spot, the vicinity of ice. But, the first shock of alarm over, we sought the cause, and found to our dismay that the narrow entrance was entirely blocked by a monstrous iceberg, which had drifted in there and become jammed between the jaws of the pass. So were we all prisoners, and at the mercy of the cold, nor could our instincts tell us how great the danger was or what were our chances of escape. My first impulse was to dash wildly at that great white wall that blocked the way to liberty; but, fortunately, 


\section{Autobiography of a Sperm Whale}

I restrained myself, and following the example of my chief, went on feeding, instinctively realising that much food was needed to keep out the effects of the cold.

So for several days and nights we remained in this prison, eating throughout every waking hour. I kept returning to the icy barrier, much as I hated and feared it, and even forced myself to try and wriggle beneath it. And at last, as I was burrowing like a sand-groper, I felt a sudden trembling of the whole vast mass above me, and with a crash as if of an earthquake I was hurled forward full twenty times my own length and lay stunned, bleeding, and helpless. I slowly rose to the surface without any volition of my own, and feebly spouting, felt my senses coming back to me. I was presently joined by my companions, whose admiration of me now was greatly increased, for they attributed their deliverance to me. But I had been so sadly ill-used by that tremendous blow that, had it not been for the stored-up energy of all the food I had been so plentifully devouring lately, and an exceptionally powerful physique, I should certainly have been unable to keep up with the school, and should probably have died quietly or been slain by order of the chief. Our mighty race tolerates no weaklings or cripples. Putting forth all my powers, I accompanied the school to the Crozets, where another rich feedingground awaited us, and by the time we quitted there I was not only fully restored to my usual vigour, but was rapidly approaching the dimensions of our leader.

Now in a community like ours there are just three ruling motives, each causing us to exercise all our powers. First, the desire for food. Instinct assisted by training teaches us whales to find it, and to that 


\section{Pride of Race}

search everything is subordinated. Our vast bodies require so much nourishment, and that of a certain kind, that we must place this need before all others. Moreover, we are, as compared with the smaller denizens of the sea, upon many of which we might feed were it possible to catch them, very slow and clumsy in our movements. The gigantic cuttle-fish alone, which hides its mighty gelatinous bulk in the submarine caves at the roots of the mountains is capable of satisfying our enormous appetites and of being fairly easily obtained. Creatures of smaller bulk and lesser prowess than ours it does not fear. They become its comparatively easy prey. But we are invincible, invulnerable; against our onslaught no cuttle-fish can defend itself when we are full grown.

This then is our primal need, as indeed it is of most creatures that live, although many are able to subordinate it to other needs for long periods at a time, notably the seals. Next comes the love motive, the intense over-mastering desire to have wives and children, and coupled with it, really a consequence of it, the desire for supremacy over our fellows. These two last only apply to the males; our females are almost like beings of another race, so inferior to us are they in size, in agility, in ferocity. The full-grown Sperm Whale cow never exceeds in size half the dimensions of the full-grown bull, and is, moreover, a gentle, timid creature whose one object is to keep near her lord, to obey his lightest sign, and who will cheerfully remain by his side and die with him if he be in danger of death. As I have before hinted they are not fond mothers, taking the earliest possible opportunity of shaking off the yoke of maternal cares, but they endeavour to make up for this by their absolute devotion to the head of the family.

The young bulls are in an anomalous position. For 


\section{Autobiography of a Sperm Whale}

a long time they are mere nobodies. They are of the family, but have nothing to do with it but obey the lead of the chief. All the privileges of his leadership are theirs, also the lore which he has accumulated gradually passes to them as they follow him about the oceans of the world. They cannot help learning, for imitation is one of the primary laws of their being, which they can no more disobey than they can help feeling hungry. And all they have to do is to eat and grow ; love affairs do not trouble them until they are fullgrown. Then, when instinct compels them to cast amorous glances upon the young cows of about their own age, another instinct warns them that before love must come war. And so it comes to pass that at a certain period in the life of the school there are furious battles between the young bulls, battles that sometimes result in the death of one or both of the combatants, and sometimes in that terrible disablement and disfigurement known as twisted jaw, where the bone of the long mandible-like lower jaw is wrenched to one side, at right angles to the line of the body. Then the sufferer is thrust out of the school, never again to know the fellowship of his kind, but to wander unsatisfied and lonely until his lif:'s end. The victor in the battle, upon which the great chief of the school looks gravely and with perfect impartiality, may then form a school of his own. He proudly selects for himself wives from among the young cows and departs to use for himself the wisdom he has learned during his adolescence.

So the making of new families goes on until finally there arises a young bull who, seeing that the leader is not so fierce or so agile as of old, feels called upon to put his headship to the test and haply succeed in driving him from his place and filling the same himself more efficiently. Then a tremendous fight ensues, lasting 


\section{My Ambitions}

sometimes from the rising to the setting of the sun. And the outcome is often that the old king is beaten, deposed, and driven forth to wander solitary, it may be for many years, through the wide oceans where once he ranged as an ocean monarch, leader of a great family, but now doomed to finish his journey alone.

Now in this long digression I have sought to show the customs of our people as regards family life, for the reason that to me was rapidly approaching the time when I must needs do battle with my peers for the right to lead. I had no choice, nor did I desire any. I felt keenly eager to fight, the more so because my two exploits had already brought me fame, as it is understood by us, and also because there were several winsome cows who looked lovingly upon me. They kept near me in the school when we were on our passages, in spite of the jealous efforts made by the other young bulls to edge between us. Many attempts were made to provoke me to fight, but I disregarded them all. Mine was a loftier aim, a higher ambition. I aspired to leadership of the school, although there was no sign visible that our chief was growing too old to lead. All the more glory I felt, for me, if I could overcome him and take his place.

Consequently battle after battle took place among my young fellow-bulls, and several new families were founded and led away, as we journeyed about the oceans of the world. One battle royal took place in the Indian Ocean, near where I was born, and a contemporary of my own, born three days after me, led off four young cows triumphantly. Another founded a new family on the coast of Japan, another off the Sandwich Islands, another in the North Atlantic, where a great ship-full of men and women paused to view the fight and held their breath to see how fiercely strove the monarchs 


\section{Autobiography of a Sperm Whale}

of the deep, though knowing nothing of the cause of quarrel or of the prize of victory.

Still I bided my time, to the wonder of my companions, until a younger generation was fast approaching the time when it too would attain to full whalehood and free citizenship of the ocean. Meanwhile, I always kept close to the chief, watching his every movement, noting all his wise ways, and absorbing all that he had to teach, until at last, as we fed around the bases of that lonely rock in mid South Atlantic, Inaccessible Island, while the furious southern storm raged around us and lifted its vast waves towards the sky, I calmly challenged his supremacy. He had given the signal to depart northwards in consequence of the inclemency of the sea. And I questioned his wisdom. I pointed out that here was abundant food, that the storms did not affect us, that all were well content to remain here but he, and that it appeared as if the leadership of such a school as we were was becoming a task beyond his powers. Other family matters I touched upon which need not be enlarged about here, such as the dwindling numbers of our new calves, quite insufficient to supply the waste of departures. And I concluded by offering to contest the headship with him at once.

During all this time the rest of the school lay in a wide circle of which we two were the centre, their huge black bodies almost motionless, like wave-beaten rocks protruding above the surface of the foaming sea. He and I lay nearly head on to each other without movement, not seeing each other, but that mysterious sense of ours, which I have before mentioned, in full activity. Well was it for me that I had waited so long, and had rehearsed to myself all possibilities of his behaviour when I should challenge him. For suddenly, as if hurled by a stupendous wave, he launched himself at 


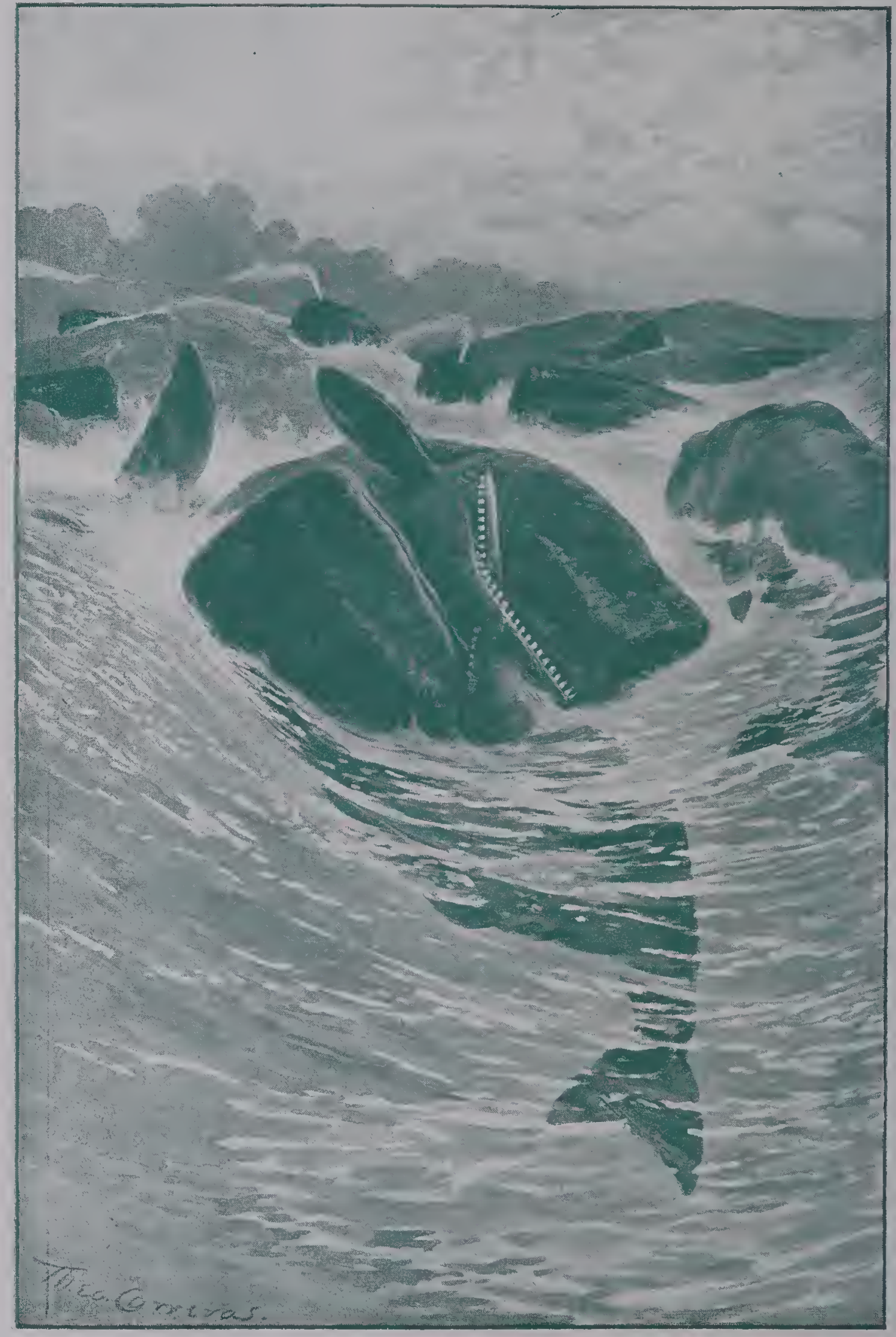

THE CACHALOT'S DEATII STRUGGLE.

[To face p. 35 . 


\section{Win the Headship}

nie-and missed me by a yard, for I had felt him coming and given one tremendous sweep with my flukes that had carried me forward and downward withal. Keeping just beneath the surface I felt for him cautiously, every sinew tense for the blow I meant to deal when I should touch him. But I had for an adversary one of the wiliest as well as mightiest of Sperm Whales, and my only hope of victory, apart from the chances of accident, was to copy his tactics with that rapidity of learning which is our birthright, and trust to my superior youth and consequent vigour to put them into practice for his defeat.

So we circled around each other warily, he occasionally making one of his awful rushes either under or above water, according to our position at the time, for while life remains to us we must obey the irresistible call of our lungs, and rise or sink in accordance therewith. I kept strictly on the defensive, husbanding my strength for the first sign of my old ruler's weakening, and so, without harm done to either, the long fierce day rolled slowly on. Then I noticed that his rushes were not so vigorous, he was losing his caution, and also his temper, for every silent taunt that we know so well how to convey without making a sound, he was now using profusely.

Suddenly I saw my opportunity; he was lying in such a position that he could not see me, and his vast lower mandible hung down temptingly, a gleaming white bar against the deep blue of the sea. Without making a ripple $I$ arched my body nearly double, then releasing the tension sprang forward at him, turning withal and gripping his jaw in mine. The ocean boiled with our efforts, he to free himself and I to hold on. At last came a rending crack, I felt the jaw give in mine, and knew that I was victor. Releasing my hold $\mathbf{J}$ 


\section{Autobiography of a Sperm Whale}

sprang to the surface and awaited his coming. As soon as he appeared I rained blows upon him with my tail until all motion on his part ceased, and he lay, except for the gentle wash of the waves about his limp body, quite supine. I immediately mustered the school, gave the signal of command, and in a compact body we all sped away, leaving our late chief to enter into a new sphere of usefulness in the bodies of the myriad scavengers of the sea already hastening to the enormous banquet I had spread for them.

Thenceforward I led the school triumphantly through the various oceans for many years. But I never allowed a young bull to linger when it was time that he should go. If he refused the combat I would drive him out ; I would have no one wait for me as I did for my chief, although I had little to fear, for I had become even a mightier monarch than he, and wiser by far, I knew. Yet never did I get an opportunity to show my wisdom's ripest fruitage until one day off the old Solander again, where I first felt the touch of that horrible barbed weapon: I knew that there were enemies about. I ordered all my tribe to make full speed to the westward, while I remained to guard their retreat; and wonderfully they obeyed me. In the space of three spouts they had disappeared, gliding along beneath the sea at top speed. I lay as if asleep, but by an almost imperceptible motion of my flukes gradually turning, turning, so that when three of the white monsters I remembered so well rushed upon me, I, seeing them coming, suddenly turned a full somersault and fell among them. One was crushed to fragments, the other two strove to escape, but I hurled myself after them, as the dolphin after the flying-fish, and presently they had both fallen into morsels under my furious blows. Then, calming down at once, I followed 


\section{My Serene Adolescence}

in the wake of my family, sedately satisfied, but resolved never to tempt my fortune and that of those dear to me, by venturing on the Solander Ground again.

And now I think I must conclude my story. I am still in the full-tide of vigorous life, not yet more than half a century old, and probably destined to lead the school for another quarter of a century. Then it may be my fate to be ousted by one of my family and roam solitary for many seasons more. But I hope not. I would fain end my splendid career in battle at the jaws and flukes of one of my sons, who should be a worthy successor. Very pleasant my life has been to me, the few really dangerous meetings I have had with enemies having only served to heighten the delight of living. I have been, and am, fondly loved; I have always been hungry, and always found food in abundance. I have traversed every sea, and been respectfully greeted by every form of sea-folk-they have even saluted me when about to enter the vast cavern of my stomach. My thick coating of creamy fat, the huge reservoir of oil I carry in my head, has grown richer and richor, until now I am wealthiest of my people: never have I seen one of them that would dare measure his might against mine.

I inherit the pride of my splendid race. I know that we are the oldest of living created things, as well as the mightiest, and I rejoice to know that the persecution we once endured at the hands of the big-brained insects of the land is over now, or practically so. Every hour of my life is a delight. The swift, irresistible rush along the raging sea, or the soft gliding through balmy waters lit up by mellow sunshine, the sudden chango as we sink into the cool, translucent depths, and the thrill as we seize the musky mollusc in his lair and, dragging him upwards, tear and devour his juicy, succulent flesh. 


\section{Autobiography of a Sperm Whale}

The long, steady journey of thousands of miles, straight as the dolphin leaps, without molestation, with only the happy company of our own people, and the long, pleasant days when, free from the necessity of watchfulness, we take our fill of love, of food, and of sportive gambols : ah! these are the things that make our life in the deep, the beautiful sea, thrice happy.

There be many things about us that none can ever know but ourselves; our sickness, which produces matter treasured by the greedy earthmen; our length of days; our small brains, but great intelligence-these are of the deep-sea secrets that pigmy man shall never understand. But to you, my friend, because you have loved us and striven to do us justice, I have revealed thus much, in the hope that the knowledge may bring you joy. And so, farewell! 


\section{CHAPTER III}

\section{THE MYSTICETUS, OR RIGHT WHALE}

$\mathrm{P}$

ARTLY because my acquaintance with him is so much less, and partly because I know that his intelligence is of a much lower order than that of the sperm whale, I shall not permit this huge creature to tell his own story. Indeed, I could not; for there is a secret connected with this particular whale which has never yet been revealed, nor, although it is a bold thing to say, does there seem any prospect that it will be. Briefly, it is, what does he do with himself during the long night of the Arctic regions, when open water, absolutely necessary to him as to other sea-mammals, is not obtainable, all the Polar Seas being locked under many feet of ice? Nothing can well be more certain than that he does not come south. He has never been seen in temperate waters, not though the enterprising whale-fishers, driven south by the encroaching ice at the approach of winter have sought him with infinite care. Where, then, does he spend the long months of the Arctic winter, utterly dark but for the Northern Lights (Aurora Borealis), utterly unnavigable by any ice-breaker known?

Some have formulated a theory of an open Polar Sea, whither birds and mammals retire during this bitter time, but the idea is chimerical, untenable for a moment. If there is anything firmly settled concerning the Arctic regions it is that, whether ariy 


\section{The Mysticetus, or Right Whale}

explorer reaches the Pole or not, we know exactly the conditions which obtain there. In any case, only six hundred miles or so separate the farthest north of the explorer from that apex of the earth known as the North Pole, which when it is reached will certainly be just the same dreary dismal expanse of hummocky ice or frozen snow-covered land that we already know so well.

Where, then, does the Right Whale go in the winter? We do not know, but an easy and plausible assumption is that he hybernates beneath the ice as does the alligator in the mud, the bear in his hollow tree, the marmot, and the dormouse, not to speak of other hybernators or winter sleepers. As an assumption this must pass until we know, which does not seem at all a likely thing to happen.

The Right Whale of the Arctic Seas, Bowhead of the North Pacific, is probably, individual for individual, the largest of all God's creatures. But there is some little doubt as to his being larger than the sperm whale, because whalemen calculate the sizes of their gigantic victims by the number of barrels of oil they yield. Now the sperm whale, ranging temperate and tropical seas, does not need, and therefore does not carry, a great thickness of blubber over his flesh. True, the reservoir of spermaceti in his head does something to equalise this, but not enough. The greatest yield of oil and spermaceti from any sperm whale that I have been able to obtain any information about was sixteen tons, while I have heard of several cases of Bowhead in the Behring Sea trying out nearly twenty-five, blubber alone, since they have no spermaceti. Yet I feel sure, judging by experience, that the sixteen-ton sperm whale would be bulkier than the more thickly clad Bowhead. However, let it go, it's a moot point, 


\section{The Easeful Whale}

and whalers generally seem to be agreed that there is not much to choose between these monsters in point of size. That is as regards one sex, but the females of the Mysticetae are, as a rule, larger than the males, while, as I have before said, the sperm whale cow never exceeds half the size of the bull.

Their lives, by a curious contrast with the spermwhale, are spent in slow-going, easy fashion. In spite of their terrific surroundings of crashing ice-bergs, ice-fields heaving under the tremendous pressure of the storm wave, and bitter blighting winds laden with death to any alien intruder into that stern domain, the Right Whales are placid, quiet, peaceful; with an appearance of great content with their surroundings. The Almighty has ordained that these vast denizens of the frozen Northern Seas shall be at no pains to secure an abundant supply of food, and by one of those paradoxes that Nature seems to delight in, that food for the supply of the largest of created things is made up of the accumulated myriads of ocean's smallest denizens, that is, of those actually visible. From the crow's-nest of a whale-ship on a clear day the watcher may see the ocean lined out in parti-coloured bands of red and blue, strangely regular and extending to the horizon's verge. A draw-bucket plunged into one of the red bands a hundred feet in breadth will bring up a motley collection of minute shell-fish, a crawling, clinging mass of life that has its basis of subsistence in the unseen fauna of the fecund sea.

These tiny crustacea in their myriads await the advent of the Right Whale, who ranging lengthwise along the red bands, inhales his food without an effort until the enormous cavity of his mouth is filled with untold thousands of tiny shell-fish quite unconscious of their transition. Then the wonderful apparatus 


\section{The Mysticetus, or Right Whale}

developed by this great cetacean comes into play. He bears dependent from his upper jaw a series of broad plates of gristly substance, the "whalel one" of commerce (though nothing could be less like bone). These blades, like those of a scythe, depend by their broad ends from the upper jaw, leaving their taper extremities swinging free in the great scoop of the lower jaw. Their outer edges, like the back of the scythe-blade, are thickish, their inner edges are fringed, hair-like; and interlacing each other, they form together a perfect natural sieve. Between their rows at the bottom of the lower jaw lies an immense mass of fat of nearly two tons weight in the full-grown subject, the tongue. And, the mouth being full, this great tongue slowly rises and forces out the water through the sieve, until there remains only a heap of tiny creatures out of their element and sliding gradually down a pipe of one and a half inches in diameter, the gullet of the Right Whale, which has led to so many strange errors as to the swallowing capacity of whales in general.

As the Right Whale, alone of all the sea-mammals, feeds in this marvellous way, so he alone of all whales has this strangely constricted gullet, a curious contrast again with the sperm whale, who can swallow morsels of truly heroic size, at least six feet cube in the adult. One point more in this connexion; it used to be supposed that the Right Whale, having filled his mouth with food, pumped the water out through his spiracles or blow-holes, until it was discovered that the breathing apparatus of all sea-mammals is entirely unconnected with their mouths, and that it is an absolute impossibility while they live for any water to gain access to their breathing channels. The real process is as I have described. 


\section{The Killer Whale}

As with the sperm whales, so among the Right Whales the school or family obtains, but in far smaller numbers, and, indeed, it is not uncommon to see a bull, two cows, and two calves comprising the whole family. Moreover, there is none of that fierce competition for the headship of the school so characteristic of the great mammal of the tropical seas. Fights between Right Whale bulls are unknown, at least to man ; indeed, they seem far too ponderous and sluggish in their movements to indulge in such violent exercise as fighting. Placid, timorous, and slothful are their lives, and even while being done to death by whalehunters they seem incapable of retaliation or even escape, unless indeed some friendly floe is near, some ice-field beneath which they may dive, and haply through carelessness on the part of their aggressors, drag the latter after them to a swift but horrible end beneath that frozen covering. This sluggishness or helplessness is partly due to their shape and immense hampering of fat, in many cases two feet in thickness over the greater part of their bodies. But it may be more reasonably referred to their food costing them no effort to obtain it, and so abundant that they are never found, except in extreme old age or sickness, suffering from any lack of fatness.

A typical instance of this may be found in the ease with which the fierce Orca gladiator, or killer whale, attacks and overcomes them. $\mathrm{He}$ is rarely onehundredth of their vast bulk, but he has enterprise, and teeth in both jaws. So he, with half-a-dozen companions, will fall upon a huge Mysticetus, and in a few minutes reduce him to a helpless island of flesh with drooping lower jaw. Through that vast opening of his mouth the pirates enter fearlessly and devour the succulent tongue, disturbing for the first time a 


\section{The Mysticetus, or Right Whale}

whole tribe of suckers (Remora) who have up till then had free warren in the roof of the whale's mouth, true parasites, without aught to strive for or a need unsatisfied. Then the vast victim, his agile slayers gone, becomes the prey of ocean's tribes of scavengers, ever ready anywhere in that mighty so-called waste of water to attend to their duty of keeping ocean sweet. Birds above and fish below labour furiously at the task of ridding the sea of its incubus, and in a very short time they succeed, the immense framework of bone slowly disintegrating and sinking into those silent, unknown depths.

Nor is the Orca the only sea foe, as distinguished from man, that the Mysticetus has to fear. The swordfish (Xiphias), a huge species of mackerel, with a short sturdy shaft of bone protruding from his upper jaw, which is capable of penetrating six inches of solid oak when the two to six-hundred-pound body behind it gathers its full momentum, attacks the Mysticetus with almost maniacal fury, although it cannot do an adult much harm except by way of worry. For the shortness of the sword (lance it ought really to be called from its shape) does not admit of its penetrating beyond the blubber of an adult Mysticetus, except in non-vital parts. Still, the swordfish is a valuable ally to the killer, with whom he often joins forces, while to the young calves he is destruction itself. It is a sight not easily to be forgotten: the long lithe body of the swordfish gliding through the sea with incredible swiftness, like a streak of light of deeper blue than the surrounding sea, and, meeting the body of a threemonths calf, enter it as if it were thin air. A dexterous twist of the broad tail and the weapon is withdrawn. A gush of blood stains the water brown, and amid the murky surroundings the repeated stabs of the lance, 


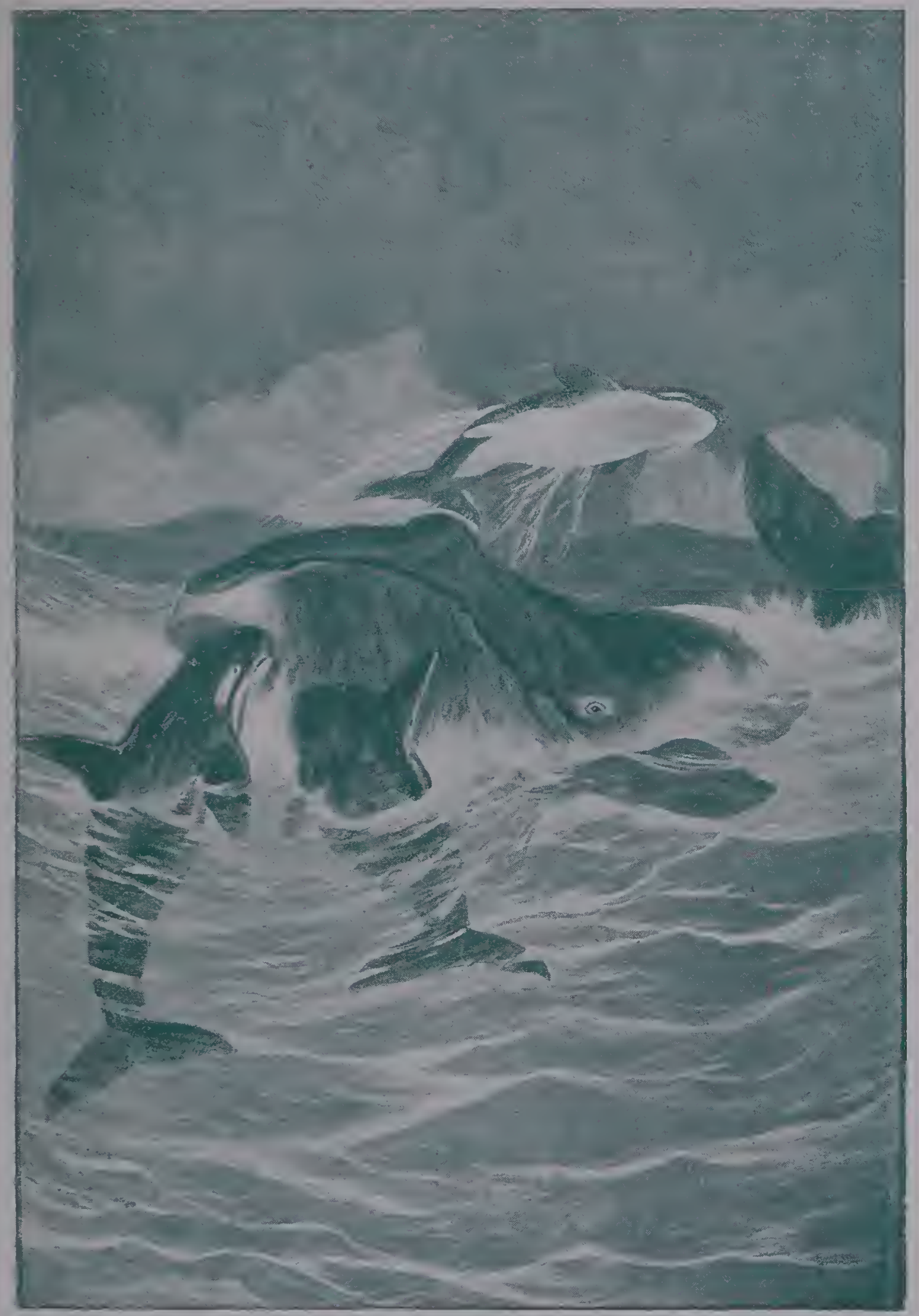

A RIGIT WHALE AND ITS FOES.

[To face $p .44$. 



\section{A Huge Victim}

the writhings of the victim, and the frantic tearing of masses of flesh from its body, are hidden, or only revealed by a few hurried glimpses.

Yet another enemy has the unfortunate Right Whale; really unfortunate, since it does not prey upon its fellow-citizens, except in the same sense in which we prey upon the animalculæ in our drinkingwater-the 'thresher' shark (Alopecias vulpes). Here I am aware that I am upon highly controversial ground, since very eminent professors of natural history deny that the thresher does attack the whale. They say, with what warrant I fail to understand at all, that what the sailor has mistaken for the attack of the thresher on the whale has been the antics or gambols of the hump-backed whale, which has long arms (fifteen feet or so), and is fond of waving them in the air and bringing them down upon the water with a loud smack. They are entirely wrong. The hump-backed whale I have watched very many times at his play, and though he does wave his arms he does not smack the water with them but with his tail. Also, I have seen the thresher shark attacking the whale at close quarters, so close indeed that every movement of the shark and his victim was plainly visible, and I can hardly imagine any one mistaking the gambols of the whale for this curious attack. The shark appears to balance himself upon his head in the water, with the whole of his enormous flail-like flukes in the air at the moment of striking; then, when the blow has been delivered there is a quick descent and return, like the lashing of a gigantic whip, while the blows are audible for two miles on a calm day. So heavy are they that strips of blubber are cut by them from the back of the hapless whale four to six inches wide, and two to five feet in length. Here, again, it is the worry 


\section{The Mysticetus, or Right Whale}

that kills, not the wounds, which are quite superficial and probably cause little actual pain. In fact, the death of the whale is seldom compassed by thresher or swordfish alone, but nearly always in active association with a group of killers.

Seeing, then, how he is begirt with enemies, and how for his valuable spoil men have always hunted him into the farthest navigaivie recesses of his habitat, it appears almost miraculous how he has survived until the present day. Yes, and it is even more marvellous when one remembers that, as compared with all the other species of whales, his range is exceedingly limited. The Arctic seas when freest from ice form but a very small portion of the watery surface of the globe. Small, that is, comparatively; yet large enough to admit of these gentle monsters eluding their many enemies sufficiently to perpetuate the race, even through the fierce war made upon them all through the last two centuries, when ships from all the Northern European nations frequented the Arctic seas in search of them. Here, probably, came in the saving power of that mysterious winter disappearance. For at least six months of each year the Mysticetae enjoyed a close season that man, at any rate, was unable to break into, and it is highly probable that their other enemies also departed south. Be that as it may, we are confronted with the remarkable fact that, incapable of effective flight or of self-defence, eagerly sought after by man and agile sea enemies, confined to one little corner of the earth periodically frozen solid, the vast Right Whale still exists, and as recently as the year Igoo was so numerous that ships in the Pacific actually took but the baleen of the whales they caught and let the blubber go, since they had so many fish they could not possibly flench them. 


\section{The Whale's Early Days}

Like the sperm whale, the Right Whale is an indifferent parent, and the young one learns as soon after birth as possible to attend to its own requirements. It grows with great rapidity, absorbing a prodigious quantity of milk from the mountainous breasts of its mother, milk as thick as the richest cream and yellowish in colour. At this period of its life the young whale is slender and almost graceful in shape, agile and full of play as all young creatures are ; but it soon settles down into the ponderous stately movements of the elder whales, and becomes like them a snug abidingplace for hosts of external parasites, such as barnacles, limpets, and whale-lice-creatures somewhat like the garden wood-louse, but larger, and with tenacious barbed claws, whereby to hold on to the slippery body of their huge host. One of the greatest pleasures in life for them is to chafe their bodies-irritated, one would think, unbearably-against the rugged sides of some mass of ice. Occasionally they may be seen doing this beneath an icefloe; then, when the need comes upon them for breathing, they calmly rise and break a hole with the crown of their heads where the double openings of the spiracles or blowholes are situated. They remain under water for as long as an hour and a half, and must remain above for a corresponding time, no matter how great their peril-from man, for instance. A certain number of breathings is an imperative necessity to all whales, and no irregularity or lessening of their number can be endured, no matter what the circumstances may be, while life lasts.

In these days the life of a Right Whale is fairly placid and uneventful. True, there are a few, but a very few, ships that still enter the icy seas each year and catch some Right Whales; but compared with a 


\section{The Mysticetus, or Right Whale}

century and a half ago, when hundreds of vessels eagerly searched every nook of those otherwise lonely northern seas, and populous wooden towns sprang up where the blubber of the whale was boiled down, for transshipment by vessels chartered for the purpose, the Arctic regions are now deserted. Soon, very soon, they will revert to their primitive condition before whaling became an industry at all, and the great Greenland Whale will peacefully roam his quiet waters unmolested by any save his natural enemies.

Closely akin to the Right Whale of Greenland is the Southern Right Whale, or Balaena australis. There are a few unimportant differences as regards outline, the Southern Whale being somewhat slenderer, slightly more 'clipper built,' as sailors say. Structurally the two are almost identical, but as regards habitat exceedingly different. Unlike his northern congener, the Southern Right Whale not only does not stick closely to the vicinity of the ice, and to all appearance hide beneath it all the winter, but he really seems to prefer the waters outside of the Antarctic Circle, and is found in large numbers as far north as the Cape of Good Hope. His best-loved region would appear to be, roughly, the vast stretch of ocean between $30^{\circ}$ and $65^{\circ} \mathrm{S}$. He is especially fond of the vicinity of land, and half a century ago, in addition to a goodly fleet of vessels, mostly French, cruising in those regions in search of him, there were many shore whaling stations, established at some point where there was good harbourage and facility for dealing with the gigantic prizes. The crews of these stations were usually a motley, hard-bitten crowd, co-partners, fierce, and careless of risk to life or limb. They chased the whale from shore in their boats, and having killed him had a herculean task to tow him back. The work both of 


\section{The Unobservant Sailor}

hunting and realising the spoil was terrific, and it alternated with long spells of absolute idleness, when whales came near enough to be attacked, or for some reason none were seen at all. Yet there was a savage freedom about it which appealed to those rough representatives of many lands, and apparently it pleased them well, in spite of its appalling dangers, terrible hardships, and scanty rewards.

A singular circumstance connected with the haunts of the Southern Right Whale is noteworthy, as showing how little of a naturalist or observer the sailor is. During the Antarctic expedition of the eighteenth century, all the log-keepers, with the exception of Captain Weddell, who was a whale-fisher, were enthusiastic in their reports of the enormous number of valuable whales (Right and Sperm Whales are repeatedly mentioned) in those tormented seas during the southern summer. Now the fact is, as one or two whaling expeditions have discovered to their cost, that the sperm whale is never found south of the Antarctic Circle, and the Right Whale hardly ever. These two species, practically the only ones commercially valuable enough to warrant the outfitting of ships for an ocean voyage in order to catch them, prefer to avoid those stern regions, and the whales seen and repeatedly logged by the crews of the 'Erebus ' and 'Terror' were of a totally different and almost valueless species, such as no ships are sent long voyages after. It would seem as if life in those tremendous regions adjacent to the eternal barrier of Antarctic ice, and the great southern continent, was altogether too strenuous for a leisurely monster like a Right Whale, even though the southern Mysticetus is so much smarter both in appearance and agility than his great northern congener. There, where the awful sea of the south, unhindered in its world- 


\section{The Mysticetus, or Right Whale}

engirdling sweep, makes the ice-islands toss and whirl like chips in a mill-race-where, even in summer, the weather is more severe than in our worst winters, and gale follows gale with a monotony of fury that is amazing - there is no place for either men or animals except those fully equipped for, and indifferent to, the hardest weather on our planet.

Little more remains to be said of the Mysticetus. In greater measure than his brother of the north, the Southern Right Whale is unmolested; indeed, it is doubtful whether a dozen individuals are taken in the course of a year, and those more by accident than design. Consequently their numbers are increasing rapidly, and as their favourite haunts are becoming less and less disturbed by the passage of ships they are gradually, after two hundred years of terror, reverting to their primitive condition of peaceful seclusion from all foes except the three natural ones already mentioned, so that in a few years it will be possible to sail, if yachtsmen are venturous enough, into great silent spaces of sea embracing many thousands of square miles that are never furrowed by any ship's keel, where the great mammals of the deep sea roam in immense herds fearlessly, because all unused to molestation, and live their ordered, happy lives out to their full extent without any interference from man whatever. 


\section{CHAPTER IV}

\section{THE HUMPBACK WHALE}

DEAUTIFUL beyond the power of description, the islands of the Tonga group lay set in a sapphire sea under an azure sky flooded with golden sun-

light; a little breeze blew, just sufficient to raise tiny wavelets fringed with snowy foam and sparkling as if set with millions of diamonds. Over the fringing coral barriers they curdled with a drowsy hum as of infinite content, as if they knew they were perfectly beautiful and perfectly fulfilling their appointed way. Only where the prevailing swell came thundering shoreward, fretting at finding its three-thousand-mile course hindered, was there any sign of the stress of elemental forces. There, with every recurring billow as it reached the coral barrier, rose a long thundering roll of breakers twerty feet high, dazzling white in striking contrast to their bases of deepest blue, and looking as if they would overwhelm the whole group of islands. Higher and higher they rose until, drooping, dejected, they owned their limitations and recoiled hissing, to make way for the next arrival.

Towards this fierce barrier there hurried nervously a mother Humpback Whale. She was of moderate size, about forty-five feet long by thirty in girth, with flattened head and mouth fringed with scanty whalebone. On her back she bore a dorsal erection like a dumpy fin, whence the trivial name 'Humpback.' 


\section{The Humpback Whale}

But her chief visible peculiarity differentiating her from sperm and right whales, was the length of her arms. Unlike the almost rudimentary pectoral appendages of the cachalot and Mysticetus, her arms were nearly onethird of her length, justifying the Greek title bestowed upon her kind of 'great wings' (megaptera). A close observer, had any such been at hand, would have noted that, as she swam straight for the reefs, she kept one of these long arms tightly pressed to her side, as if holding something of value. Stay, there were close observers, hungry denizens of the deep sea following her and watching with ravenous eyes. They knew the nature and value of her treasure, and, given but the slightest opportunity, would have despoiled her of it. But she well knew both of their unwelcome presence and their sinister designs, and sought a haven of safety where they dared not come.

Close to her side she hugged her newly born son, a slender dolphin-like creature about nine feet in length, full of vigour and impatience of restraint, who struggled fiercely to get free. Since his birth she had not known a peaceful moment, for the Creator had endowed her with so large a proportion of maternal love that the mere feeling of ought happening to her offspring was agony almost unbearable to her, while at the same time instinct warned her that the surrounding sea simply swarmed with hidden enemies, ready at any moment to deprive her of the joy of her life could they but find her momentarily unwatchful. Therefore had she forgotten her lord and leader, her fellow mothers, herself, all her being was centred upon the young one by her side and how to protect it from death.

Closely escorted by at least half-a-dozen immense sharks, she reached the Barrier Reef, sounded, and swam along its base until she came to an opening wide 


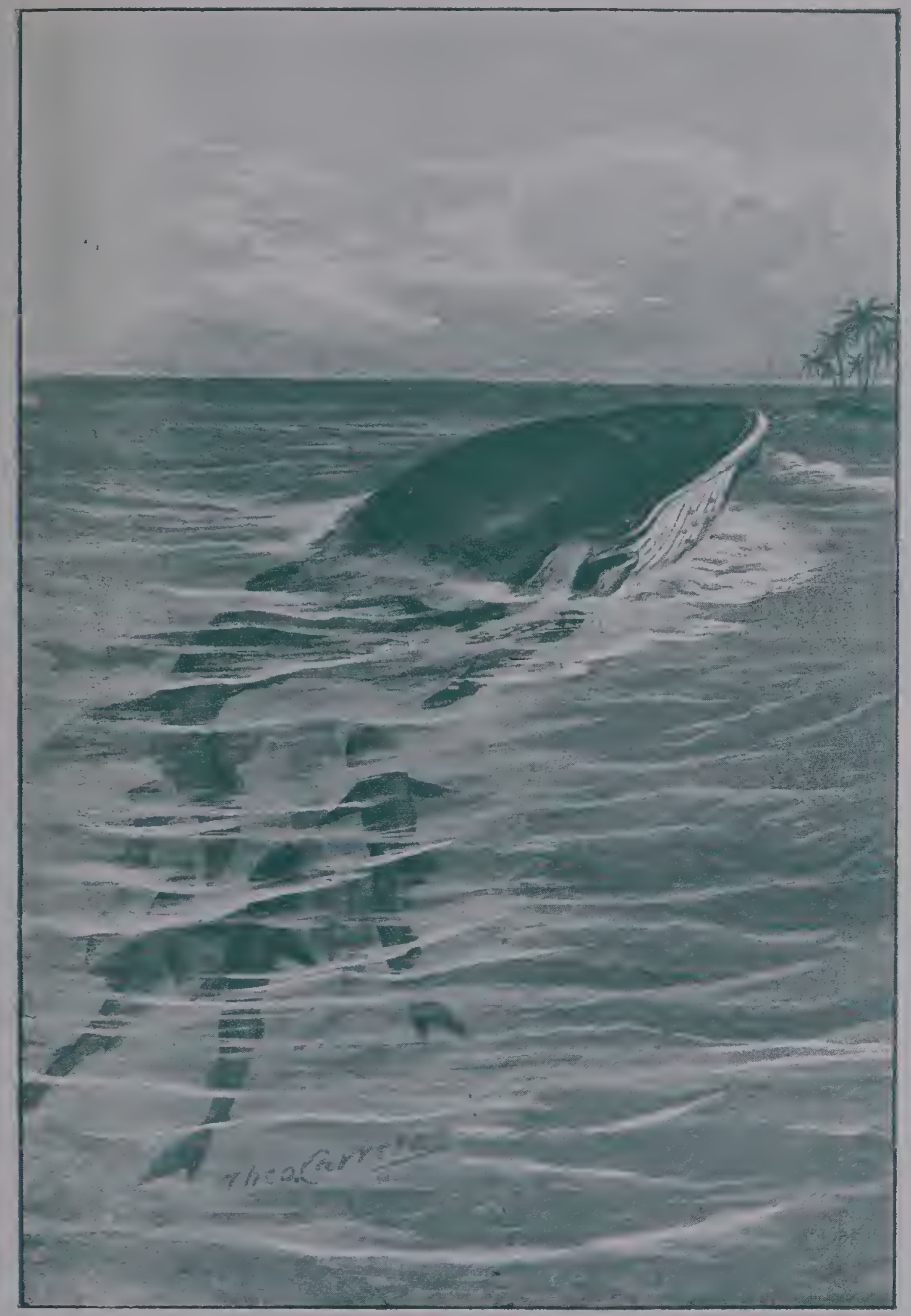

A MOTHER WHALL IYRSLED BY SIARKS.

[T1) face p. 52. 



\section{Delights of Motherhood}

enough to admit her. She dashed through and wound her way among the mazy interstices of the scattered reefs inside in the smooth placid lagoon until she reached a sort of natural little dock, where, with just sufficient water to float them, she and her baby might lie in perfect peace and security beyond the reach of those blood-thirsty creatures who had never left her since her little one came. Sweet, passing sweet it was to lie and bask in the full sun-glare, to feel the joyous gambolling of the youngling all around her, varied by an occasional tugging at her bounteous breast, to exhale lazy spoutings and watch the pretty tuft of vapour from the spiracle of her offspring, to lie, in short, so perfectly at peace as to forget that ever a danger existed.

One drawback there was which she hardly felt-the lack of food. To feed it was necessary for her to go into deeper waters and that she dared not do yet. But this want, in spite of her enormous bulk, troubled her scarcely at all, she was quite content to starve awhile for the sake of her young one, who she knew would gain so rapidly in vigour every day spent in that calm retreat as to be able, before her supply of milk ran short through lack of nourishment, to accompany her far enough to find food in safety, to cruise among the islands and between the reefs where in deep water she could obtain the necessaries of life. All that, however, was matter that did not immediately concern her. For the time she was supremely happy in the consciousness of safety for her young one, in the knowledge that she was where none of her enemies could ever come.

Poor thing, the limitations of her instinctive apprehension of danger did not, could not warn her against man, the universal destroyer, man, whose skilful hand, active brain, and unscrupulous ferocity when directed against the lower animals, makes him their most terrible 


\section{The Humpback Whale}

foe. So it came about that on the second day, just as the pearly dawn was breaking and a faint blush was tinging the summits of the sombre green hills, she lay as usual peacefully giving suck to her youngling, while the cool dimples of the water softly laved the happy pair. Suddenly she became conscious of the close proximity of danger, stiffened all her muscles while her tail vibrated slowly and her long arms reached out in agitated fashion to draw the young one into her side for shelter. Too late; a glittering harpoon flew over her back, aimed at her, but missing its mark and transfixing the calf, which instantly died.

By some strange process of deduction, quick as thought, she knew the full extent of the calamity which had befallen her, and raising her mighty tail on high made sea and shore resound with the thunder of her blows. So sudden was her transition from utter peace to the intensest fury of revenge, that the crew of the boat which had stolen up behind her through the narrow reef channel had no time to retreat. Bewildered by the rapidity and violence of the blows, and blinded by the spray, they leapt overboard and climbed with torn hands and feet up the jagged surface of the reef, only about two feet under water. There they were safe from the whale, but in imminent danger should the sea rise of being dashed to fragments upon those myriad needlepoints of coral. Fearfully they beheld their infuriated victim frantically dashing their devoted boat into minute fragments, pausing momentarily at short intervals as if to listen for their whereabouts, if haply she might by any means compass their destruction also.

Finally, after an exhibition of power and ferocity amazing to witness in one habitually so gentle, one also who would suffer her last drop of blood to be drained rather than retaliate while her calf was alive, in case 


\section{Retribution}

she should accidentally do it any injury, she slowly milled round and headed seaward, stopping every few yards as if most reluctant to quit the scene of her loss, and manifesting in every movement the acutest grief at her great bereavement. At last, with accelerated speed, she left the reef and made for the open sea, where she speedily rejoined the school she had left and communicated to them the fact of her great sorrow and its attendant circumstances. I cannot actually say that she received their condolences, but I am absolutely certain that all took solemn warning by her calamity, and as the best preventive against any similar accident to themselves all the prospective mothers determined to avoid the Tonga group as a place of refuge. But as it was a splendid feeding ground, they remained in its immediate vicinity, sometimes cruising among the reefs and between the islands for the shoals of small fish and molluscs abundant there.

One day the youngest bull of the party was suddenly attacked in the same mysterious manner as the hapless mother had been. But it was where the steep shores of the main island shelved away abruptly into a depth of a thousand fathoms, and that young bull, as soon as he felt the goad, inverted his body and plunged for the depths at a most terrific pace. The men in the boat above, realising too late that their victim was of the wrong sex and, moreover, was in the wrong place for them, just held themselves clear of the hissing line, which in two minutes had run out the whole length of its three hundred fathoms and disappeared with a snap like a stockman's whip.

The youngster, galled unbearably, and unable to tell what had happened to him, went at top speed as deep as a whale may, that is, to about five hundred fathoms, then essayed to rise to the surface once more. 


\section{$5^{6}$ The Humpback Whale}

But spent with his tremendous downward rush, and held down by the great weight of the rope he was dragging against the water, his struggles became fainter and feebler, until at last, with a sudden collapse of his great heart, his struggles ceased, and turning over he slowly sank, already the prey of innumerable seascavengers, attracted to the spot by their infallible instinct warning them of the presence of their particular form of food. So died this promising young bull needlessly, since he could not by any possibility have been caught in those deep waters, and should never have been attacked.

But perhaps it is wrong of me to give these two sad misfortunes forward first, as if they were typical of the daily life of the Humpback. Nothing could well be more untrue than such a suggestion. There be few creatures in earth, air, or sea, that lead a happier life, or enjoy it with a greater zest than the Humpback. In the pleasant waters where they roam, that is to say, practically all round the world between $20^{\circ} \mathrm{N}$. and $40^{\circ} \mathrm{S}$., wherever there is sea to swim in there is almost always abundant food. They are not so restricted either in their dietary as their cousins, the right whales. Quite sizeable fish, and cuttles of all kinds up to eight or ten pounds in weight, form their staple support. They are fond, too, of showing their joy in life, like the porpoise. They indulge in titanic gambols which fill the spectator with amazement, as he watches them roll and leap and prance about the sea-surface as if they only weighed as many ounces as they do tons. There are few more interesting and pretty sights than to watch a family of Humpbacks, bull, cows, and calves, all engaged in their play, the great leader vying with his youngest consort or her tiny calf in his efforts to show by his sportiveness how very happy he is. 


\section{The Drawbacks of Ease}

True, their enemies, which are practically the same as those of the right whale, do occasionally overtake and destroy them; but unlike their gigantic cousins, they have great speed and agility, and consequently are far better able to defend themselves, to do so, in fact, most successfully in numbers of cases. Like the right whales, too, like all whales, in fact, they are grievously afflicted by many parasites, and it has even been suggested that their almost frantic gambols are indulged in in the hope of ridding their skins of these irritating hangers-on. But that I do not believe. When the Humpback finds his load of barnacles, limpets, and slimy sea-grass unbearable, he hies him to the nearest rocky bottom of coral reef, and there drags his vast body slowly to and fro over the spiky surface, chafing off a great number of his unwelcome guests and no doubt experiencing many a delicious thrill from that superlative scratching while doing so.

In one particular, however, he is handicapped in getting rid of his parasites. His belly blubber is divided into longitudinal folds, or rugæ, lying closely and tightly together, and with a depth in these grooves of over a couple of inches. Limpets breed in these snug places, and there, secure from dislodgment, since the folds cling so tightly together that the hand can hardly be forced between them, they reach a size unknown elsewhere. I have repeatedly seen limpets as large as a horse's hoof in the rugosities of a Humpback's belly. But these, after all, are minor evils, not for one moment to be weighed against the many joys of the Humpback's life. Amiable, fondest of parents, content to play about the beautiful shores of the most beautiful islands in the world, and immune from the attack of man everywhere, except among the shallow reefs, when the mothers seek them for protection. Even that 


\section{The Humpback Whale}

danger is now almost non-existent, for reasons given before.

So that the joyous Humpback is practically free to enjoy his life, to eat and love and play in the vastest playground given by God. Even those ills to which he is inevitably subject trouble him not at all beforehand; like the rest of the humbler creation, although he knows fear, he knows not anticipation. For him the immediate present is his all, whether it be of pain or pleasure ; and it is pleasant to remember that his pleasures outnumber his pains by at least a thousand to one. In concluding this brief sketch of the Humpback's life, I would explain that where any apparently essential details are omitted, it may be understood that they are substantially the same for the Humpback as for the right whale, previously described; the important differences of habit have, I think, all been fully dealt with. 


\section{CHAPTER V}

\section{THE RORQUALS}

$\mathrm{T}$

HIS enormous class of whales, embracing many varieties, is often held by whalemen to include all whales that are unfit for merchant's purposes by reason of their scantiness of blubber or overcoating of fat, the absence of marketable baleen or whalebone, and lastly their exceeding speed and agility, rendering them practically uncatchable. This distinction has the merit of being entirely unscientific, yet near enough to the truth to be easily understanded of the people to whom the cumbrously minute, yet entirely necessary, definitions of science are so repugnant.

The study of whales, or cetology, is a most fascinating one, as indeed, I think, is all study dealing with the fauna of the deep sea, but in the very nature of the things is so difficult to attain to any degree of accuracy in, that it is simply pedantic, in writing on it for popular reading, to speak in terms of an exact knowledge concerning a creature of whom we can only see passing glimpses during life, and who when dead becomes corrupt so quickly, and to so great an extent, that he is an intolerable and pestilential nuisance at once.

In the three great classes of which I have already spoken, there is some approach on the part of those who have hunted them, like myself, to actual knowledge of their mode of life, their habits and customs ; 
but in the Rorquals this advantage disappears almost entirely. For, except in certain places and under certain conditions, such as obtained on the coasts of Newfoundland, Labrador, and Norway, the Rorqual is not, cannot be, hunted successfully. And so there are proportionately less opportunities for observing these clippers of the whale tribe, which are to be found in some of their varieties in every sea beneath the sky. Nevertheless, owing to the fact that instinct has taught the Rorqual that he has nothing to fear from ships, it is possible occasionally for a patient observer on board a sailing ship to have a fairly long opportunity of noting the behaviour of Rorquals.

One thing is exceedingly noticeable about them, their solitary proclivities. During my wanderings over all the seas, I have never seen more than two Rorquals together, and that on only three occasions. Nearly always it is one that comes from out of the great void, and, as if feeling his loneliness, makes friends with the becalmed ship and remains constantly attendant upon her, until an upspringing breeze hurries her away. I well remember the awe and fascination that one of these monsters bred in me during my first East Indian voyage. It was in the Indian Ocean, near the Equator, and on one lovely but moonless night I was lolling over the rail during a stark calm, gazing into the inscrutable depths below, where occasional flashes of green light made the surrounding darkness more impressive. Dimly I wondered what those lights were, and why they shone, when presently I became aware of a great glare far down, which was slowly brightening as it neared the surface. As it rose higher and higher I saw that the centre of this brilliancy was a long black oval growing larger and larger. And presently, paralysing me with fright, the rising mass broke the 


\section{A Mighty Visitor}

surface, there was a sound like a million sighs rolled into one, and a column of vapour rose in ghostly fashion against the deep violet of the sky. Then, though my heart still thumped violently, I recognised a whale and was somewhat comforted.

Still I had my doubts of his intentions; he was far too near, about four feet from our side, to be pleasant company. What if he should suddenly object to our presence there and assault us furiously? And I thought, with the cold fear curdling my young blood, of the awful depths beneath us, separated from us only by two or three inches of soft pine plank. I did not know then how sociable and good-natured is the 'Finback,' one of the best known of the great Rorqual family, one also who, like the sperm whale, but with even a greater range, may be found in nearly all the navigable seas of the world. For some few minutes after rising he lay leisurely by the ship's side apparently considering her appearance and occasionally spouting softly. Then he slowly settled down, and presently the whole ship vibrated as if grating over rocks, but with far less violence. And peering over one side from the main yard-arm I saw the halo round our visitor glowing beneath our keel, and realised that he was rubbing himself against us, as cattle rub against a fence. The calm lasted with brief intervals of light airs from all quarters for four days, during the whole of which our visitor never left us. Fasting too, as far as we could see, although it is hardly safe to say that nothing entered that capacious throat of his, because we could not see it. But we had splendid opportunity for observing his every movement, the exercise of all his powers, as closely as if he had been cased in an aquarium and we just standing peering through the glass. 


\section{The Rorquals}

Many times since I have had opportunities of watching, not only the Finback, but other Rorquals in all parts of the world from this well-known habit of theirs of consorting with becalmed vessels, but never better than on that early and well-remembered occasion. Yet, strange to say, I have never seen a Rorqual calf, nor have I ever met a whaleman who has. Whether some deep maternal instinct warns the Rorqual cow that at such a time she cannot exercise her normal powers of flight in case of aggression, or what it is, I do not know. But I believe that she does have an instinctive desire to hide herself during the time of nursing, and succeeds in so doing.

Fortunately for the Rorquals they are far less valuable commercially than any other whale. Their blubber is very thin, their baleen very scanty, and as I have before noted, their strength and agility are such that, except under such conditions as obtain in the fishery of the places I have mentioned, it is almost impossible to kill and secure them. I couple the two terms because the Rorquals almost invariably sink as soon as dead, and in deep water such a habit is fatal to any chance of securing them. A sinking whale cannot be stopped from doing so by any means known or available to whale-fishers. Not only have they these commercial drawbacks, but living advantages, for the resultant oil is exceedingly poor in quality and low in price.

Yet the thrifty, hard-bitten Norwegians, able to wrench a living from their iron-bound shores where men of lesser endurance, strength, and perseverance must inevitably starve, have devised a way of capturing and making commercial use of the Rorqual. It is brutal and utterly unsportsmanlike, but one cannot consider the claims of sport where hungry mouths are 


\section{Whaling for Bread}

clamouring for bread. Briefly, small steamers, like the 'jackal' tug-boats of the Thames, of full power and good sea-endurance, are fitted out. In the bows they carry a cannon designed to fire a massive harpoon instead of a shot or shell. To the harpoon is attached a stout rope, far stouter than ordinary whale-line, which is one and a half inches in girth. A powerful steam windlass is fitted in the bows also. When the signal comes from the watchers on the hills that whales are near, the steamer slips her moorings, where she has been lying with banked fires, and puts out to sea, guided by certain flag directions from the headland where the look-out is stationed. Presently coming up with the whale, who is quietly gulping down a multitude of cod and other succulent dainties of a fishy nature, the gun is fired, the great harpoon buries itself in the quivering body of the monster, sometimes indeed with a small bomb in its head. He plunges seaward, dragging the steamer after him and severely testing the value of harpoon and line. But, as a rule, with scarcely any exception, once the harpoon has found its mark the fate of that Rorqual is sealed. The wound is so deep, the strain is so great, that in a short time he succumbs and sinks dead.

The water is not very deep, so, although he must needs be allowed to sink while he is sinking, he is no sooner at the bottom than the windlass is started and the great body begins to rise again. As soon as it is at the surface, measures are taken to secure it by the head for towing, and off goes the steamer harbourwards, dragging her giant quarry. Arriving at her station, the huge carcase is handed over to eager butchers and boilers, who not only strip off the blubber, rip out the scanty baleen, and tear every vestige of fat from within to swell the tale of oil barrels, but even chop up the 


\section{The Rorquals}

bones and stack them after boiling for transportation as manure. The living thus gained is precarious and poor, subject to frightful perils and no recognition, but it is not quite so bad as the similar industry carried on across the Atlantic, by the tremendously handicapped citizens of Newfoundland and Labrador. However, enough of this fishery, which I have only briefly alluded to, to show the one way in which the Rorqual is molested by man.

One species of Rorqual (Balaenoptera sibbaldii sulphureous) has the distinction of being the longest of all species of whale. The whalemen call it the 'Sulphur Bottom,' all the underpart of the body being of a bright yellow. It is a harmless, amiable monster, following the usual custom among giants, notable as being always more docile than lesser folk. But its terrific capabilities in the way of speed cause it to be left severely alone by whale fishers, and consequently it is fairly plentiful and attains its extraordinary length of sometimes one hundred and fifty feet. It has another peculiarity differentiating it from all other whales-the height of its spout. Optical illusion and the angle of vision may possibly vitiate my statement, but I feel sure I have seen a Sulphur Bottom spout as high as our main yard, forty feet. These are the free lances of the sea. None molest them; even from the spiteful attack of the grampus or Orca they are free-no Orca would dare attempt an attack upon so swift an animal.

But the chief characteristic of these great seamammals (the Rorquals generally) is their omnivorousness with regard to fish. As long as they confine their attentions to such wonderful deep-water nurseries of edible fish for man as the Newfoundland Banks, the Agulhas Banks (off the Cape of Good Hope) and the Rockall Bank. fishermen only feel slightly aggrieved. 


\section{The All-Devouring Rorqual 65}

They know that the harvest of the sea is so abundant, so entirely fitted for all the varied needs of its population, that the surplus which man may dip into without any fear of diminishing the supply by one scale is always there, that no danger of exhaustion is ever likely to arise at sea, whatever may be the case ashore. Yet their complacency receives a severe shock when Rorquals are found haunting the Channel of Old England, and th' Irish and North Seas during the herring and mackerel seasons, relays of fish-devouring giants whose appetite is insatiable, whose digestion is that of a flour mill. Then do the fishermen wail. Is it to be wondered at?

Patrolling with perfect ease those prolific coasts, the Rorqual calmly swims through thousands of pounds' worth of nets, shovelling down into his vast maw boatloads of herrings or mackerel at each gulp. The gossamer of the nets he does not heed, they do not even annoy him, so slight and trivial are they. So, his appetite growing by what it feeds upon, this mighty denizen of the deep sea comfortably wallows in the shallows near our shores, feeding, ever feeding, upon the countless myriads of fish which should have been awaiting the fishermen, but are, by reason of this awful visitation among them, driven into deeper waters and smaller companies to avoid him. Meanwhile he, the subject of our interest, enjoys himself, all unknowing and unheeding of the maledictions of the fishermen and the panic of the fish, devouring continually, always hungry and always eating, until change of season sends the herring or mackerel to sea again, and he must needs follow or pursue some new line of food-procuring ; they are all well known to this deep-sea denizen.

It would be a comparatively easy task, but I feel one that would not be received with any enthusiasm, 
to prolong this section almost indefinitely, for really there are so many kinds of whales, each with welldefined peculiarities, and methods of living that are interesting to note, that a very big book might be written about them alone.

But I have to remember that there are very many other deep-sea people claiming notice, and consequently must be as brief as I can in dealing with those I have left to the tail of this Rorqual section. The smaller Rorquals, such as the Bottle Nose (how is it, I wonder, that so many landsmen seem to have a nodding acquaintance with the Bottle Nose Whale? Perhaps because captains generally, upon a whale being sighted, and a passenger asking its name, usually reply nonchalantly, 'Oh, that's a Bottle Nose'), the curious Beluga or white whale which furnishes our 'porpoise' hide boots and boot-laces, the ca-aing whale, the porpoises, the dolphins (Delphinidae), each and every one of these has a family history of its own, very interesting to read; but one may have too much of cetology, if so undignified a chat as mine about them can be dignified by so stately a title. Therefore I will only make a few references to some of the smaller whales by way of amends to them for devoting so much time to their gigantic relatives, before passing on to another great division of the population of the sea.

Who that has ever been a sea passage, however short, and kept his eyes open to his surroundings, has not seen a Dolphin, or more likely many of these interesting little whales, which in some branch of their enormous family have the widest sea range of any of the cetacea? And not only sea-range, but in spite of the fact that they are true denizens of salt water, are continually found far inland preying upon the finny population of rivers, and in a few cases presenting us 


\section{The 'Happy' Whales}

with the only vegetarian examples that we have among the sea-folk except some turtles and that strange monster the sea-cow. But few people outside the ranks of scientific naturalists have any idea of the great number of varieties there are among the Dolphin. It is probable that in their zeal for minute classifications, naturalists have named many as distinct species which were really the same but having slight variations in form, colour. or even structure, due merely to Nature's abhorrence to turn out two exact copies of the same creature.

When due allowance is made for this, however, it remains certain that there are at least forty different species of Dolphin, subdivided from nineteen genera, ranging from the Orca, or grampus, of twenty feet long down to the little porpoises of the Eastern seas, with a maximum length of four feet, and rejoicing in a scientific designation of extraordinary proportions. Most of them, however, are known to seafarers by the generic name of Porpoises, with the certain exceptions of the killers, the white whales (Beluga), narwhals, and Black Fish. For the seafarer has a curious rooted exception to calling what he considers a Porpoise a Dolphin, many generations of use having fastened the latter name upon the beautiful Coryphona, of whom much by-and-by.

These diminutive whales are decidedly of intense interest to naturalists, as it is possible to keep them in captivity and study their habits. Moreover, in a slow-going ship one may spend many a pleasant hour watching them as they gambol about the bows keeping her strict company. Their motions are probably more graceful than that of any living thing, while their activity is astounding. No other creature would seem to have so much superabundant vitality to throw off 


\section{8}

\section{The Rorquals}

or to be so filled to overflowing with the sheer delight of living. Rest seems impossible to them, and therefore, while a swift steamer of say fourteen to sixteen knots will soon lose their company, a vessel going only four or five will not keep it long, the one because it is impossible for them to continue playing their pranks around and about her at that speed for more than a few minutes, the other because she does not permit them to get as much exercise as they need. A speed of six to ten knots suits them very well, and I know of few prettier sights than, when going at that speed on a clear moonless night, is afforded by a troop of these agile cetacea gambolling under the bows in mazy whirls of glowing green light, or spreading out fan-wise in broad bands of lambent flame as they rush towards the horizon and in a minute or two converge upon the ship again like a series of blazing torpedoes bent upon her destruction.

They seem, more perhaps than any other of the sea-folk, to have a wonderful prescience as to the weather. This peculiarity is noticed in Shakespeare (Pericles, Act ii., Scene I).

3rd Fishermam: 'Nay, master, said I not as much, when I saw the Porpus how he bounced and tumbled? They say they are half-fish, half-flesh; a plague on them ! they ne'er come but I look to be washed.'

All seamen realise that the abnormal activity of a creature always extraordinarily active presages a storm ; indeed, it would be impossible to pass the matter without notice. To see a school of Porpoises some thousands strong rushing at amazing speed across the foaming sea with a roar like that of billows breaking upon a reef during a landward gale, and to notice that, even in that mad and apparently objectless race, individuals are here and there hurling their quivering 


\section{Amenities of Porpoise Life 69}

bodies twenty feet into the air, as if it were impossible for them to be violent enough in their exercise, is to feel, no matter how dull one may be, that something out of the common must be going to happen. The theory of some great enemy being in pursuit is untenable, for these stupendous stampedes are always succeeded after a few minutes by a like period of steady easy-going, except that here and there some excited member of the family will be seen indulging in a solitary leap or so. Then there will be another race, and so on.

Life is pleasant for the Dolphin in all his varieties. The amazing fecundity of the sea supplies abundant food-fish of many sorts and the smaller cuttle-fish being obtainable in vast numbers wherever the Dolphin frequent, from Antarctica to Jan Mayen. Enemies they have, of course ; as we descend the scale of size we find the struggle of life grows fiercer, but they are far better off than the Mysticetae. For their vicious relative the grampus must put on top speed to catch them, as must also the sword-fish, except in the case of cow porpoises with young. Like the humpbacks and Rorquals generally, they are devoted parents, taking the utmost care of their young, and defending them at cost of their own lives. The young are very docilemany times it has been only by the closest observation that I have detected the tiny calf, looking not much bigger than a large trout, apparently glued on to the side of its mother, so closely did it follow her every movement, however rapid and erratic.

One habit obtains among the smaller Dolphins which is not practised by any other of the cetacea. It is the cannibalistic one of immediately tearing in pieces and devouring any one of their number which happens to get wounded. Many a time have I seen one slip off the harpoon, with a great rent in his side from which 


\section{The Rorquals}

the blood was spirting in jets. Immediately the whole school would close in upon him, rending him with their keenly armed jaws until in a few moments there was no trace of him to be seen; the disrobed skeleton had sunk, to be finally polished by the minute scavengers of the sea ere its deposit on the silent mysterious floor of the ocean.

They are of little value commercially, owing to the small amount of blubber they carry, although there is a legend among whalemen of the oil from the Porpoise's jaw being worth a guinea an ounce for watchmakers' use. But I do not know how far this is justified-I should say it was just a yarn. They used to be valued as food, but now I do not think anybody but sailors would eat them, and sailors only in the absence of anything more palatable. Their flesh is like very dark, fine-grained beef with a strong flavour of fish.

The strangest member of the Dolphin family is undoubtedly the Narwhal, that curious cetacean which has one or two teeth so abnormally developed that they have been utilised for bedposts ; most people have seen pictures of this bizarre-looking whale, with the long twisted yellow horn of ivory sticking straight out from his nose. There is very good reason to suppose that the idea of the unicorn as shown in our royal arms may have been taken from this extraordinary Dolphin; much more reasonable one would think than that it should have been taken from the ungainly rhinoceros. It is restricted in its habitat to the Arctic regions, and is supposed by a great many of the natives to be the male of the Beluga, or white whale, a supposition which is worthy of some credit, owing to the similarity of structure, other than the horn, between them. Only the Beluga does not confine itself to feeding in the sea, but on the Alaskan coast pursues the salmon far up 


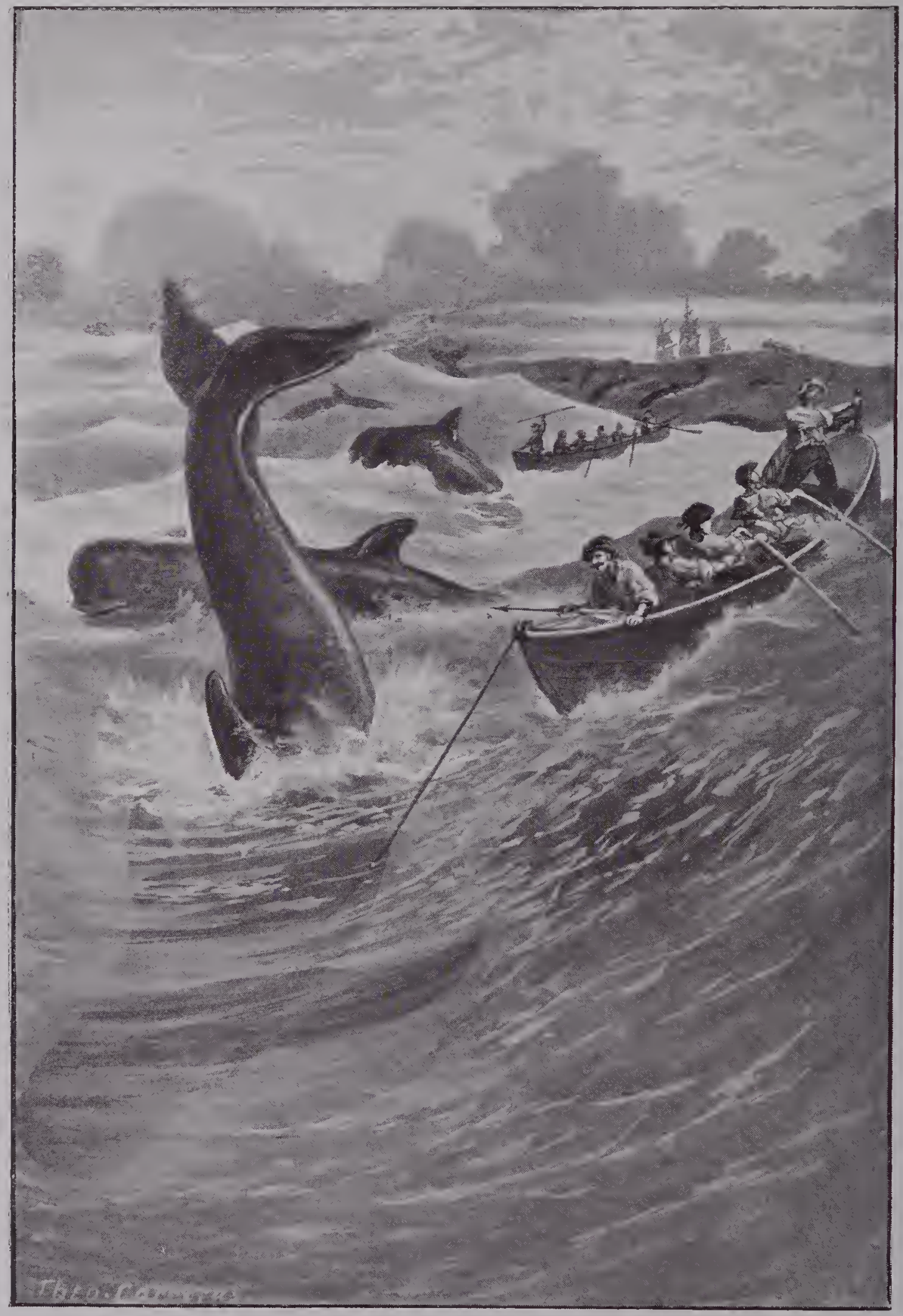

IIARPOONING BLACKFISH.

[To face p. 7. 


\section{The Confiding 'Black Fish' $7 \mathrm{I}$}

the rivers, a feat which the Narwhal has never been known to perform. He contents himself with groping in the muddy or sandy bottoms of shallow Arctic waters, stirring up sluggish fish, and transfixing them with his horn prior to pushing them off and swallowing them. This may sound fantastic, far-fetched; yet it was the opinion of so good a man and close observer as Captain William Scoresby ; and after all it is precisely what the sword-fish does, on the evidence of many observers, myself among the number. And what the sword-fish does I am sure the Narwhal can do, being quite as agile and certainly more intelligent.

The Black Fish (Globicephalus) is a miniature sperm whale to all appearance, having a huge square head, and much spermaceti in it. It feeds in the same regions as does the cachalot, but sometimes in enormous numbers. It is one of the largest of the Dolphins, for I have seen individuals weighing over six tons, and yielding three to four barrels of excellent oil. While not nearly so sociable as the Porpoise, using the word in its sailor sense, it is a confiding beast, permitting a boat to approach closely enough to harpoon it without manifesting any alarm. And when one of the school is harpooned the other boats may pull up and harpoon as many as they list, for an insatiable curiosity seems to seize upon all the family to see whatever had befallen their friends. I have often seen as many as a dozen of these bulky creatures secured by four boats at one lowering, and the utmost difficulty experienced in getting through the assembled crowd of survivors, which, however, made no attempt to avenge their slain comrades.

Like the rest of the dolphins, the Black Fish appears to be very happy. Since the decline of the whale fishery to its present exceedingly low ebb it would seem 


\section{The Rorquals}

as if the worst of his enemies are removed, for he is too agile to be caught, and too large to be gobbled up if caught, by his fierce cousin the Orca. If one could judge of the mental condition of animals by their facial expression, it would be quite natural to suppose that the Black Fish was a creature of sunny disposition and one whose lines had fallen in pleasant places, for he has an innocent smiling expression, owing to the peculiar shape of the mouth and the profile that is almost ludicrous to see. But I confess that when first I saw it I did not think it ludicrous, I rather felt that it was a shame that such a jolly-looking animal should be chased and killed for the sake of getting a few gallons of oil out of him. 


\section{CHAPTER VI}

\section{SIRENIA}

I $\mathrm{T}$ seems meet to close these observations on whales generally by a few remarks upon what is really the connecting link between the whales and the seals, between those mammals who spend all their time in the water-cannot live out of it-and those who, while living entirely on the produce of the sea and perfectly at home there, can yet make shift to live ashore for a while, settle their love affairs there, and produce their families. Such a link is found in the strange creature called trivially the Sea Cow, but scientifically the Manatee and Halicore. They are both riverine and coastal mammals, feeding upon algae at the bottom, perfectly harmless and almost helpless creatures, almost unable, in spite of their great size, to keep from becoming extinct. In fact, one species (Rhytina), once plentiful on the shores of Behring Straits, has become extinct-its enemies had little difficulty in removing it from the list of extant animals.

Most readers of Kipling's fascinating sea idyll, The White Seal, will remember Kotick's meeting with Sea Cow, and his following them to the wonderful beaches where man never came. Like all the work of this great writer, his description of the Dugong and Halicore is marked by scientific accuracy, and points out clearly the remarkable structure of this connecting link 
between land and sea animals. In every way they are a compromise ; but a study of them is of the utmost value as showing how the transition from land to sea of all the whales took place. A careful examination of them shows various characteristics almost identical with those of seals, such as nostril-shaped blowholes, large, expressive eyes, and whiskers on the muzzle, while scattered about the body are many bristly hairs, evidently a survival of the hairy covering of a land animal being replaced as the sea-life is taken to by a coating of blubber beneath the skin.

But the grand peculiarity about the Sirenia is their vegetarianism. Some of the Delphinidae do eat algae, those, that is, whose habitat is some great river like the Amazon or Ganges, but even with them it is certain that they are not exclusively vegetarian, from the contents of their stomachs, and there is even a doubt in some minds whether the presence of vegetable matter in their stomachs is not a matter of accident rather than preference. But the Manatee and Halicore are, undoubtedly, exclusively vegetable-feeders, which at once places them upon a plane apart from all their fellows in a rigidly carnivorous community. Is it any wonder that one species (Rhytina) has become extinct? They are too gentle for their stern world; as much out of place in it as a herd of antelopes in a jungle peopled with tigers.

The first sight of the Dugong as it lifts its queer head above the surface is startling. Although upon a close examination it would be impossible to trace any resemblance whatever to the human form divine, yet, from the pose of the head and remembering the suddenness with which it pops up, perhaps on a brilliantly moonlit night, one can find some excuse for its scientific generic name, Sircnia, some justification for the old seafarers 


\section{The Faithful Sirenia}

who, from its appearance, wove their fabulae concerning mermen and mermaids. Only, like all the whales, not even excepting the Beluga, it has no voice. Any sound it makes, or any whale makes, is due to the rushing of the air through the spiracle or spouthole, and not to any laryngeal exercise. The Manatee and Dugong, moreover, have an aditional claim upon our notice, and a proof of their close connexion with the higher land intelligence, in that they have been tamed.

The late lamented superintendent of the London Zoological Gardens once trained, or, rather, took over the training, of a young Manatee in Surinam, which would come to him as he waded into its pond and permit him to hold it in his knees while he gave it suck from a feeding-bottle. And there is a record of one of these strange anomalies being kept as a pet by a Spanish South American governor for twenty-six years, during which it behaved itself quite as sensibly as any exclusively land animal could have done, even to the extent of allowing the boys of the household to ride it round its lake.

After this, it is not surprising to learn that its fondness for its young is as strong as that possessed by any of the cetacea, not excepting the humpback, although its power of defending its offspring is exceedingly limited, for the Manatee has a tail like a beaver and not at all like a whale, which member, though useful enough to swim with, is of scarcely any value as a weapon.

Another marked feature of this strange animal's life is its conjugal love. It has one mate, to which it faithfully clings, nor will it leave its spouse even under the extremest pressure of fear, preferring death to separation. Thereby it is at once lifted on to a plane in our estimation far above that of any other sea- 


\section{Sirenia}

mammal or amphibious creature, all of which have very elastic habits as regards their connubial associations. I leave the Sirenia with regret as being at once one of the most interesting and one of the strangest of all the denizens of the Deep Sea. 


\section{CHAPTER VII}

\section{THE WALRUS, MORSE, OR SEA-HORSE}

ROM the Sirenia to the Walrus is one of the easiest steps, for Sea Vitch, as Kipling calls the latter, is ugly and uncouth enough to be one of the very same family as the dugong, although in truth he is nothing of the sort. But at the outset I feel impelled to enter a stern protest against the gross libel upon that beautiful animal the horse, perpetrated by calling the Walrus a sea-horse and the hippopotamus a river-horse. What, in the name of common-sense, have either of these most ungainly brutes in common with one of the most elegant and beautiful of all known animals ? Not that I would rashly call any of the Creator's wonderful designs ugly -I do but speak after the manner of men. But there does appear to me to be such an utter lack of appreciation of similarity in the conferring of titles like the foregoing. Nor is the manatee any more like a cow ; still, there is not quite the same jar to our sensibilities in the comparison, since the cow is not what one would truthfully describe as graceful, either in outline or movement.

Perhaps of all land-walking animals, not even the Myrmecophagus, none can compete with the Walrus for clumsiness. He has a gigantic body-in the fullestgrown adult about a ton in weight-and about as unsymmetrical as a leathern bag of oil or the body of a hippopotamus. It is covered with a tough gnarled 


\section{The Walrus, Morse, or Sea-Horse}

hide, scantily clothed with coarse brown hair, very patchy, in fact not at all unlike one of those old hair trunks we used to see occasionally. The fore flippers are very short, and the hand-like members are planted flat at almost right angles to the body, while the hind flippers have no legs to them, being apparently just an ornamental appendage to the body in lieu of a tail. Consequently he who can watch the progress of a Walrus over land or ice and not laugh must be quite devoid of humour or any sense thereof, for it is certainly one of the most droll-looking methods of progression conceivable.

But, as Dr. Johnson is reported to have said of the dancing dog, the wonder is not that he should perform so strangely, but that he should perform at all. For the body in an adult will weigh about a ton, and the road over which the creature ordinarily travels is one of the most rugged or slippery imaginable : a floe with a surface like a mirror, or a mass of rough hummocks where the ice has been broken up by the sea, and, coming together again, has conglomerated and congealed in the most fantastic shapes. At the upper extremity of this oblong mass of flesh is the head, ludicrously small as compared with the body. It looks almost as if the body had suddenly tapered to a slightly elongated point. And where one naturally looks for the brain, at the top of the skull, there is apparently no room for one, only a flat solid-looking mass of bone. The skull, however, is abnormally powerful, as it need be, for depending from it at right angles are the characteristic tusks, like a pair of pickaxes. With these the Walrus, suddenly rising from the bottom, hooks on to an ice-floe, and with an almost incredible exhibition of strength hauls himself up out of the water and into the berth he has selected for his sun-bath or doze. With the same 


\section{The Gentle Walrus}

tusks, too, he digs in the sea-bed for his food, which is principally shell-fish, although he does not disdain the offal of a dead whale, or indeed anything else of an animal nature, so long as it does not involve the chase of the object.

Pursuit is not at all in the programme of the Walrus, except under certain circumstances to be alluded to presently. The stomach of a Walrus that I once examined (caught on a floe in Behring Straits) looked like the contents of an oyster-dredge just hauled up. Curious shellfish of many kinds and in several cases alive ; stones, sand, mud, shrimps, worms, and other things; it was a queer collection. Yet it seemed-if such was his regular diet, and I have no reason to suppose that it was not-to have suited the Walrus very well indeed, for he was so fat that out of his wounds exuded almost as much oil as blood.

As might be supposed from the nature of its food, the Walrus is a gentle and inoffensive creature. Here, again, a sense of extreme incongruity is aroused in one at the sight of a Morse suddenly popping up from under the sea. Its appearance is savage in the extreme; no painted Indian ever succeeded in making himself look more terror-striking than the Walrus, and his bristling whiskers, each hair almost as thick as a porcupine quill and completely hiding the setting of the tusks, serves excellently to heighten his appearance of ferocity. Yet, generally speaking, at the sight of man he will flee as fast as he can, with every appearance of earnest desire to get away. The exceptions to this rule are found during the breeding season, among both males and females, the former in defence of the latter, and the latter in defence of their young. And as they are very sociable creatures, loving to herd in hundreds, an attacking boat suddenly finds itself surrounded by a 


\section{The Walrus, Morse, or Sea-Horse}

herd of infuriated Walrus, each armed with the formidable weapons before noted.

Contrary to the expectation aroused by its appearance, the Walrus has a large and fully-developed brain, although it is not especially notable for intelligence. But then the study of the brain is so far from being well advanced that we do not yet know why the elephant with its comparatively insignificant brain should be so much more intelligent than the ox, one-eighth of the elephant's bulk and with a brain almost as large. Or why the sperm whale should be so intelligent, with a brain about the same size as the ox and a body one hundred times larger. Perhaps in the latter instance there is a distribution of brain at points along the spinal column, so that messages from outlying parts of the body should not have so far to travel. I do not here try to be funny but only state what has been seriously suggested by naturalists.

In one respect, at any rate, the Walrus is the equal of any of the higher intelligences. That is in the parental quality. No animal cares for its offspring so long or more lovingly. No animal will willingly undergo more suffering and privation for the sake of its young. There can be no doubt that the female Walrus suckles its young, and provides other food for it as well during the latter part of the period, for two years. This has been, I think, abundantly proved by observation, and, moreover, the great canine teeth which develop into the formidable tusks characteristic of this animal, and without which it is impossible for it to live, do not show more than an inch or two until it is two years old. But the mother never seems to weary of her huge burden, the baby, if it be a male, often reaching its mother's proportions before it is weaned. With infinite, devoted patience she cares 


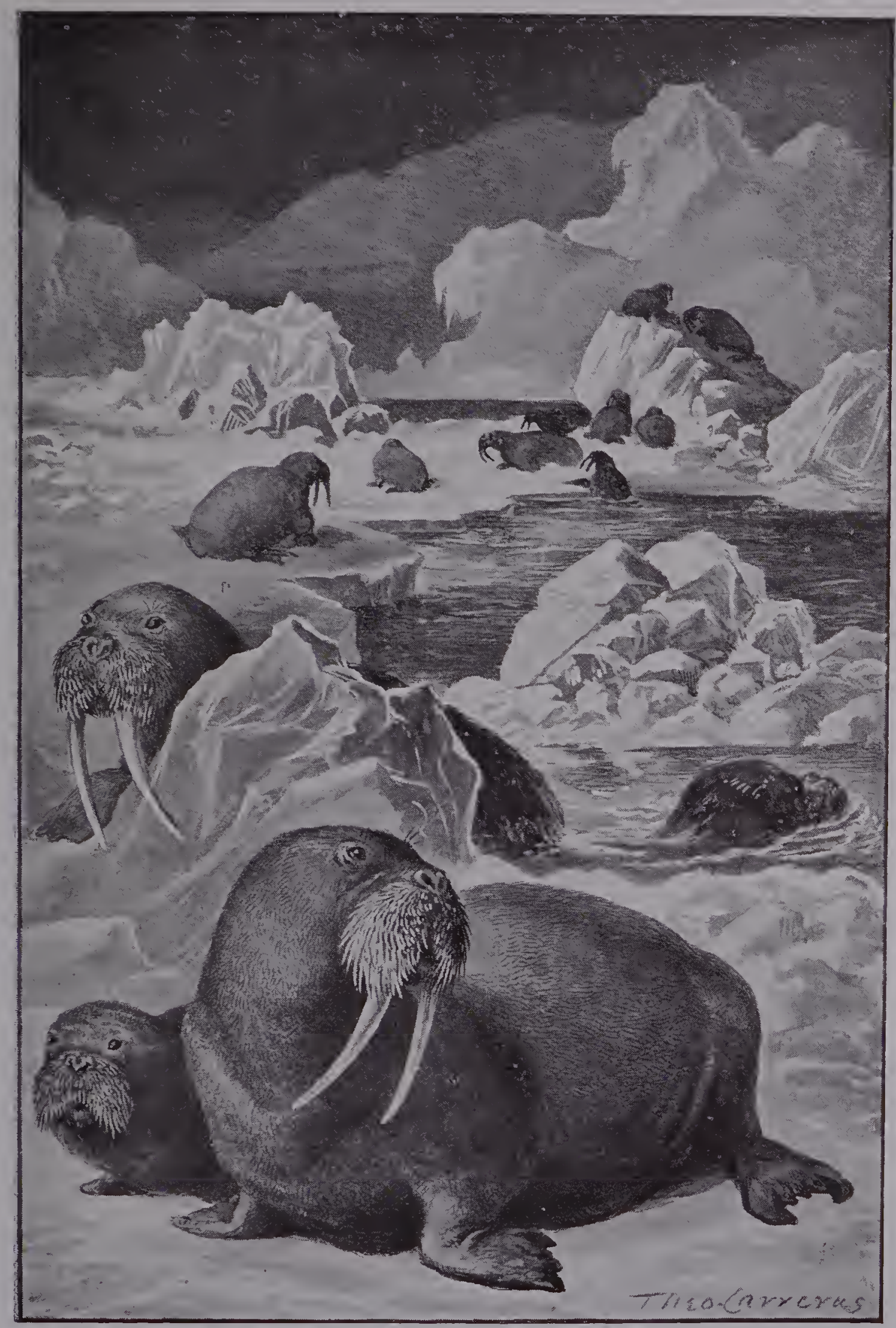

THE HAUNTS OF THE WALRUS.

[To face $p .80$. 



\section{Defence, not Defiance 8I}

for it, watches over it, defends it with her own body, and, one is tempted to say, loves her burden so much that she is grieved when she must lay it down.

However that may be, it is certain that the Walrus for all their uncouth appearance, and extraordinary method of living (so totally different from all other sea mammals whatever), enjoy their lives to the full in the best sense of the term. In one respect, indeed, they are extremely fortunate: with the exception of man, they have no enemies. The great Polar bear does not lightly engage in a combat with 'Awuk,' since he knows that in those formidable tusks he has opposing weapons that are quite a match for even his tremendous claws and teeth, while the hide of the Walrus is so tough and thick as to be almost impenetrable to even the onslaught of the great white terror of the Arctic seas. Consequently, the Walrus lives a fairly peaceful life among his fellows. He does not prey upon them, and Nature has so equipped him that they cannot prey upon him.

But man has wrought terrible havoc among the Walrus. Even as far back as 1327 , it is recorded in a receipt preserved at Bergen that the Greenlanders paid their tribute to the Crusades in Walrus tusks. And all along the Labrador coast as well as the Gulf of St. Lawrence, where a Walrus now would be almost as great a curiosity as a seal on the English coasts, they were a century ago so numerous that hundreds were slaughtered in a day. Various causes have, however, reduced the hunting of the Walrus to an insignificant matter chiefly confined to the Eskimo, who are entitled fairly to the produce of their hunting, since they are sportsmen in the best sense of the term. They do not kill for the sake of killing, but for their very life, and the Walrus is one of their chosen objects 


\section{The Walrus, Morse, or Sea-Horse}

of the chase for his succulence (from an Eskimo standpoint), from his lack of speed, and from his love of shallow waters, where he finds the humble molluscs upon which he feeds. Such gaps as the Eskimo make in the ranks of the Walrus will do no more than preserve the natural balance necessary. If only civilised man will let the Walrus alone, having found that the hunting does not pay, there will soon be as many as ever there were to people, if not exactly to beautify, the lonely Arctic regions. 


\section{CHAPTER VIII}

\section{THE SEA ELEPHANT}

$\Lambda \mathrm{S}$ far as size goes, this giant seal could probably give points to the walrus, but he is certainly not so ferocious-looking. Except for the curious nose (whence his Greek name) he is just a big black seal fairly agile in the sea, and clumsy ashore, like all his kind. Again, but for his partly-developed proboscis, he should be called sea hippopotamus, rather than Sea Elephant. $\mathrm{He}$ is about the bulk of a hippopotamus of the same age, although more hirsute and with a less extensive opening of the jaws. His proboscis is just an extension of the skin of the nose, which usually hangs down limply before the mouth for about a foot, and is inflated when the animal is enraged or excited. The young ones and females are destitute of this appendageone cannot call it an ornament. He holds among seals the unique position of being common to both hemispheres, although from the ardour with which he has been hunted, very few specimens exist now north of the Equator.

Like every other sea mammal which I have hitherto dealt with, he has now a respite, and is consequently increasing in numbers rapidly. He forms practically the only population of many an otherwise lonely series of barren rocks in the Southern seas, finding in the inclement waters washing their bases the humble food he desires (for like the walrus, and for the same reason, 


\section{The Sea Elephant}

lack of speed and agility, he cannot feed upon swiftmoving creatures). Once they abounded in immense. herds upon all the islands in the Antarctic Ocean, notably Kerguelen's Land and the South Shetland. To those barren spots vessels repaired with crews that were ready for any fate. These men were landed upon those awful solitudes, just bare rocks set in a roaring desolate sea, without a green thing to gladden the eye, and with the almost perpetual rage of the ocean endeavouring to daunt them. They had only the most impromptu shelter, their food was of the coarsest, intoxicating drink was unknown among them, and in this forlorn condition they lived for six months at a time, without seeing other faces or hearing other voices than those of their own little company. In the chase of the Sea Elephant, they ran terrible risks, endured incredible hardships, and their reward after a successful voyage worked out at something like Ios. per week. Only the hide and blubber were sought, the Elephant Seal having no fur.

My own recollection of this miserable business is a brief one, but quite lengthy enough to make me thankful that I shall never repeat the experience. In an evil hour I engaged to proceed from New Zealand to the Auckland and Campbell Islands in search of Sea Elephants, being assured that it was not only exciting sport, but a very pleasant pastime. Alas, for the depravity of humanity! Could anything be less worthy of the title of pastime than that? And yet I am sure that, as compared with similar work upon such terrific rock-bound islets as the South Shetlauds or South Georgia, it might even be called sport or pastime. For the Auckland and Campbell Islands in summer have a garment of vegetation, and there are many flowers. There are also trees, and 


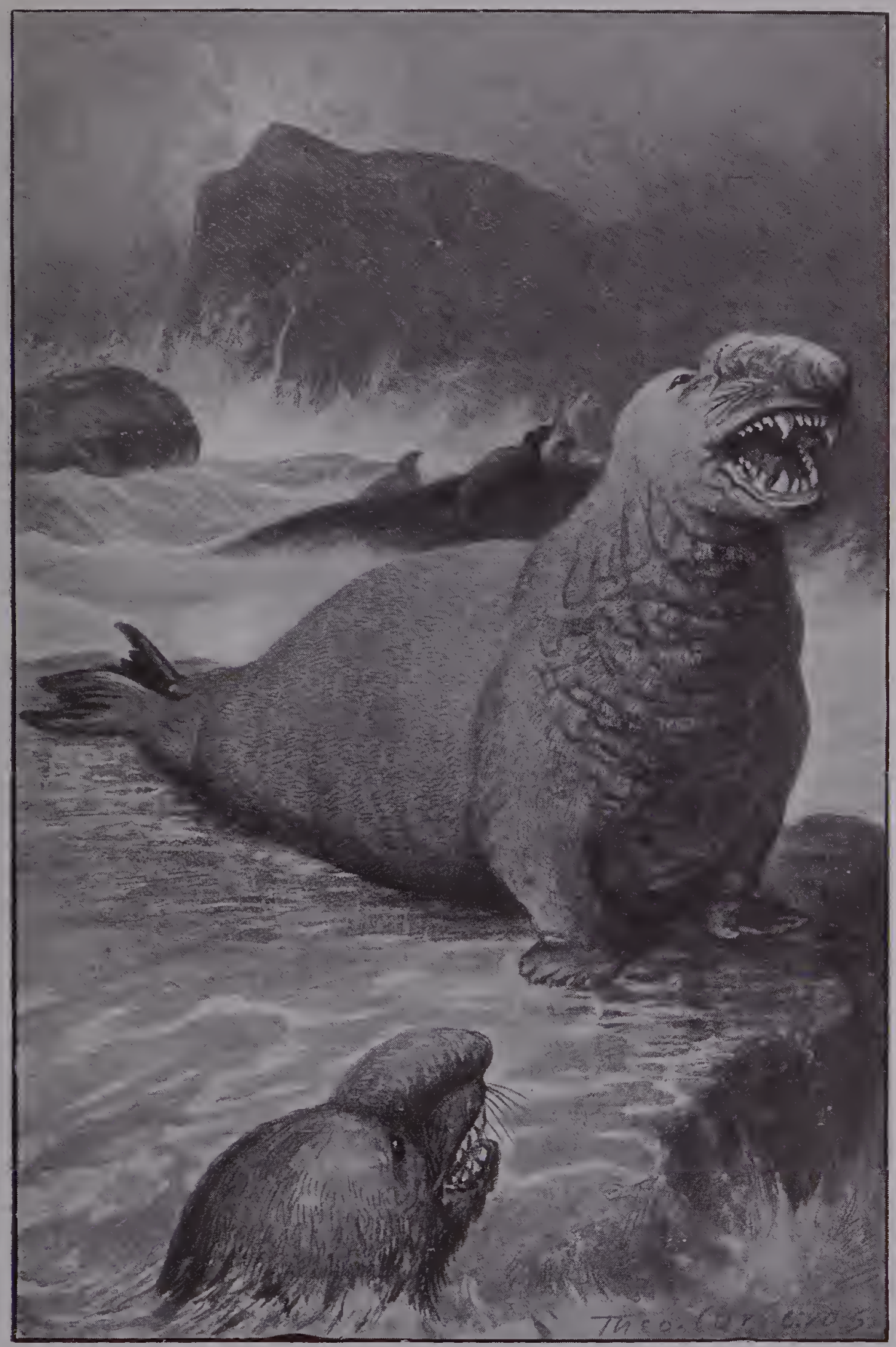

SEA-ELEPHANTS.

[To face p. 84 . 



\section{Compulsory 'Sport' 85}

considering the high southern latitude, the place is almost habitable for an Anglo-Saxon in fair comfort But the weather is vile when the storm-fiend is abroad, which is about every other day. Such is the force with which those mighty southern waves strike these lonely mountain-peaks rising from the sea right in the track of their world-engirdling sweep, that the whole atmosphere is full of spray, and walking abroad, one's hair and beard become encrusted with salt. Also much of the land-surface is bog, exceedingly dangerous to traverse, and, with the frequent dense fogs which prevail, almost impossible to avoid.

These islands bsing a favourite haunt of the Sea Elephant, we went there in search of them, and set up our try-works on the promising spot. Provisions and materials for building huts having been landed, the ship sailed away; it was no place for a vessel to linger at anchor. Better by far face the utmost fury of the open sea. We watched her departure with a pang, for now we felt desolate indeed ; but our thoughts were rudely interrupted by the curt orders of our officers, who wanted to know if we thought we had come there for a picnic. So we plunged into work of the hardest in order to get things a bit ship-shape ; but before we had been toiling an hour we were all suddenly startled stiff by a most tremendous roaring, as of a troop of lions newly landed. Our hesitation was but momentary, for our two officers, recognising the sound, bade us grasp our clubs, sheath our knives, and follow them. We did so, and presently, coming across a ridge of rock into view of a little exposed bay, we saw at least a hundred of these huge seals emerging from the broken water and lumbering shorewards.

We watched them with intensest interest, feeling grateful for the rest, and also (I speak for myself) most 


\section{The Sea Elephant}

curious to know what sort of a reception these monsters would give us when we burst in upon them armed only with clubs. True, we had been told repeatedly that all we had to do was to smite them fiercely on the nose, and they would fall an inert mass at our feet, when we were to cut their throats immediately. But somehow a sight of them did not seem to inspire us with much confidence in our ability to carry out these simple orders to the letter. They looked so aweinspiring in that luminous haze. There was a gentle drip drip of moisture from the rocks around distinctly audible between the long, sullen, thunderous roll of the breakers, and the occasional hideous roaring of the seals, and to my excited fancy it seemed as if it were the ticking of the clock of my life almost run down. For natural scepticism asserted itself, and I did not, could not, believe that our enterprise was as free from danger as I had been so repeatedly assured.

At last, after what seemed an interminable time of waiting, during which my hand got quite glued to my club from the nervous energy of my grip upon it, the last of the mighty family slowly heaved his huge bulk out of the surf and waddled after the rest inland. $\mathrm{He}$ had hardly put a dozen yards between himself and the water-line, when, in a low, hissing voice, our chief said: 'Now, then, spread yourselves along the beach between 'em an' the sea. Remember, a good bang where the trunk joins the head and then a clean swipe across the neck with the knife as hard as you can cut. Don't do nothing but that to as many as you can.'

Off we all rushed, he leading us, without a sound save the patter of our feet on the sand until we were all between the Elephants and the sea. Then we raised a yell, startling and vigorous enough to dominate the koum of the breakers. I saw the hindmost monster 


\section{A Fearsome Fight}

stop and look about enquiringly, I noted that the herd had also paused, their dim forms swaying to and fro, as they endeavoured to find out by sight or scent the cause of their alarm. Presently another yell completed their undoing, and they turned and made for the sea again. Now I do not pretend to any daring whatever, but if I did, I think I should have been justified in wishing to be elsewhere then. The charge of that troop of monsters down upon our little band, entirely unversed in this warfare, and armed only with clubs not much heavier than a policeman's truncheon, was a severe test of nerve and faith.

But our chief saved the situation. He faced the leader and smote him so felly upon the spot he had indicated to us, that the vast mass of the body collapsed like a burst bladder and spread itself upon the ground. That fired us, and immediately we were all doing likewise, yelling like demons at the same time. Why, I do not know, but so it was. But we were not to come off scatheless. One man missed his blow and his footing at the same time, and putting his left arm out to save himself from falling thrust it into the monster's gaping jaws. Now the Sea Elephant can crack pebbles as large as goose-eggs like nuts, and does do so, apparently for sport, so that when we drew Sandy from underneath his fallen foe, and prising open the jaw, released his arm, it looked more like some shreds of red rag than anything else. Some rude 'first aid' was applied, and the work of slaughter went on.

The upshot of the raid was twenty-one elephants killed, of which I know our chief was responsible for ten. And we were a study in ruffianism - 'gaumed' all over with blood and grease, stumbling over the smallest stone from very weariness after the reaction had come, yet compelled to toil on with only a few 


\section{The Sea Elephant}

minutes' rest at long intervals all through the night at the unfamiliar work of skinning those great beasts, then securing the masses of fat-laden hide to a rope, dragging the greasy plunder over the intervening space, of a roughness hardly conceivable. Yes, it was a crude experience, and remembering the triviality of the reward, I am filled with wonder at our folly for ever undertaking it. But we did not know, nor did we take the trouble to enquire. I must not forget to mention before I leave this uninviting part of my subject that Sandy did not lose his arm. In spite of the bones being broken, nay almost ground to pulp in several places, and the extensive laceration of the flesh, also the exceedingly primitive surgery, he was able to use the arm again in six weeks, and long before that was assisting as best he could in the work with one arm.

Strangely enough, I could put no heart in my work, for I could not help feeling all the while that I was in the position of the unprovoked aggressor, and that whatever happened to me, I should deserve all I got. And that is no frame of mind to go a-whaling or a-sealing in. But perhaps I had better not extend my personal recollections of the Sea Elephant any farther, or I may convey quite a wrong impression of him. It is true that by accident he or she, as the case may be, does inflict serious injury upon the aggressor. But this is quite accidental. I am persuaded that the Sea Elephant, except among his fellows at the mating season, and even then in far less proportion than the common seal, is harmless. As his diet will testify, he is no insatiable hunter after higher organisms. Cuttle-fish, those snaky, uncanny things, that seem to have been created in order to provide food for a full half of the sea mammals, and the lower mollusca, 


\section{Contented with Little 89}

yes, even so small as mussels, are the daily food of the Sea Elephant and, like the walrus, very satisfying he seems to find them. Secure in his impervious coating of fat and hide, he loves to lie upon the battered and bare rocks with the spindrift hissing over him, as cosy as a cat upon a hearthrug before a blazing fire. Loves to watch the gambols of the pups learning to swim in the boiling surf, and to nuzzle in the ooze at the bottom of the sea for the succulent morsels which cannot escape him. Altogether it cannot be denied that the All-Wise One has given to the Elephant Seal a high and enviable place among the sea mammals; and now that man's desire for his particular products has been satisfied by other and more easily and cheaply obtained substitutes his lot will be as near being perfect as any animal's can or ought to be. For he has no enemies other than man. 


\section{CHAPTER IX}

\section{SEALS}

O many and diverse are the varieties of Seals, and $\checkmark$ yet so closely are they allied, that I am compelled to take them as one family, and in order to economy of space and reader's patience, class them perfunctorily as one family, which they really are, it is true, but very widely severed. Still to the average reader, like myself, a Seal is a Seal, and there's an end on't, whether the precise naturalist may class it as Sea Lion, Sea Bear, Sea Leopard, Harp Seal, Saddle-back Seal, or any other arbitrary distinction whatever. These minutiæ, deeply valuable as they are, do not interest us; we only want to know enough to satisfy our curiosity, not enough to qualify us to be curators of our local museum. We have other work to do. From the sea elephant then, down to the next largest, the Sea Lion, is a longish step. No such gap, in point of size, separates the rest of the Seals, wide as their diversities are. But in one respect, agility, speed, and grace, tria juncta in uno, they are all far superior to the sea elephant.

No one who has ever watched a Seal in his native element, and possessed anything of an eye for beauty of curve and grace of motion, can ever forget the exponent of these delights to the eye. No fish, swim he swiftly as he may, can hope to escape the pursuit of the Seal. Like a streak of brown light, he glides 


\section{A Living Miracle}

through the sea and grips his finny prey when fleeing at top speed. And he has need; for the Seal has, like the shark, a tormenting liver. Not in the direction of indigestion, but of digestion. Its secretion of digestive juices is so abundant that hardly is the stomach filled before it is empty again. And who can wonder at it after witnessing the amazing expenditure of energy by one of these beautiful creatures during one bright morning, say off the Pribyloff Islands?

Yet there is one feature of the Seal's life that is truly miraculous, not to be accounted for by any known hypothesis whatever. For ten months of the year the 'old man' Seal needs, and gets, fully one hundredweight of fish per day to keep him fit. During the other two months he fights, makes love, never sleeps, never drinks, and never eats. Behold here a natural miracle. Many animals there be who fast through longer periods, but all their natural forces are quiescent, dormant; the waste of tissue is infinitesimal. The Seal only, throughout the most strenuous period each year of his intensely strenuous life, neither eats nor drinks nor sleeps for two months on end.

There are many things in the lives of animals, even those closely associated with us, which are difficult to understand, but this little matter of the Seal's abstinence from nourishment and rest during the time of 'his greatest activity is, I think, the most marvellous and non-understandable of all. Like other animals, normally gentle at every other period of the year, except the mating season, the male Seal is then transformed from the soft-eyed amiable amphibian, harmless as a dove to everything, except the fish upon which he lives, into a furious beast with bristling moustache, 
bared teeth, and glaring eyes, ever spoiling for a fight, and as often as not covered with torn and gory wounds from head to foot. These do not seem to cause him any inconvenience, or allay his fierce desire for battle.

Not that he is guilty of fighting for fighting's sake alone-I would not do him that injustice. First of all, upon arriving at the breeding-place to which the colony of Seals he belongs to resort each year, each male selects a spot where he and the mate or mates who will presently arrive (for the Seal is not monogamous) may lodge. It should be as near the sea as possible, and also near a beach, but its location is preferred among the rocks or rough ground. Having selected a spot about ten feet square, the thing is to retain it against the ever-arriving Seals from their oceanic wanderings, each eager to eject some already established landholder. So it is fight and watch day and night to hold their own.

By-and-by the female Seals arrive, each a mother elect, and then the scene simply baffles description. It says volumes for the vitality of the poor females, that they not only survive the terrible treatment they receive, but actually seem little the worse for it. As each one reaches the rocks she is pounced upon by a roaring frenzied mob of males, seemingly bent upon tearing her limb from limb. Not only is she bitten and torn most shamefully, but she is banged upon the rocks as if she were a mass of india-rubber rather than a living thing. Finally, she becomes the prize of the most vigorous, who seizes her with his teeth by her neck, drags her off to his reservation, and dumps her down there. Then having fought to obtain her, he must now fight to keep her, and in between-whiles do a little skirmishing, if haply he may acquire an extra wife or so. 


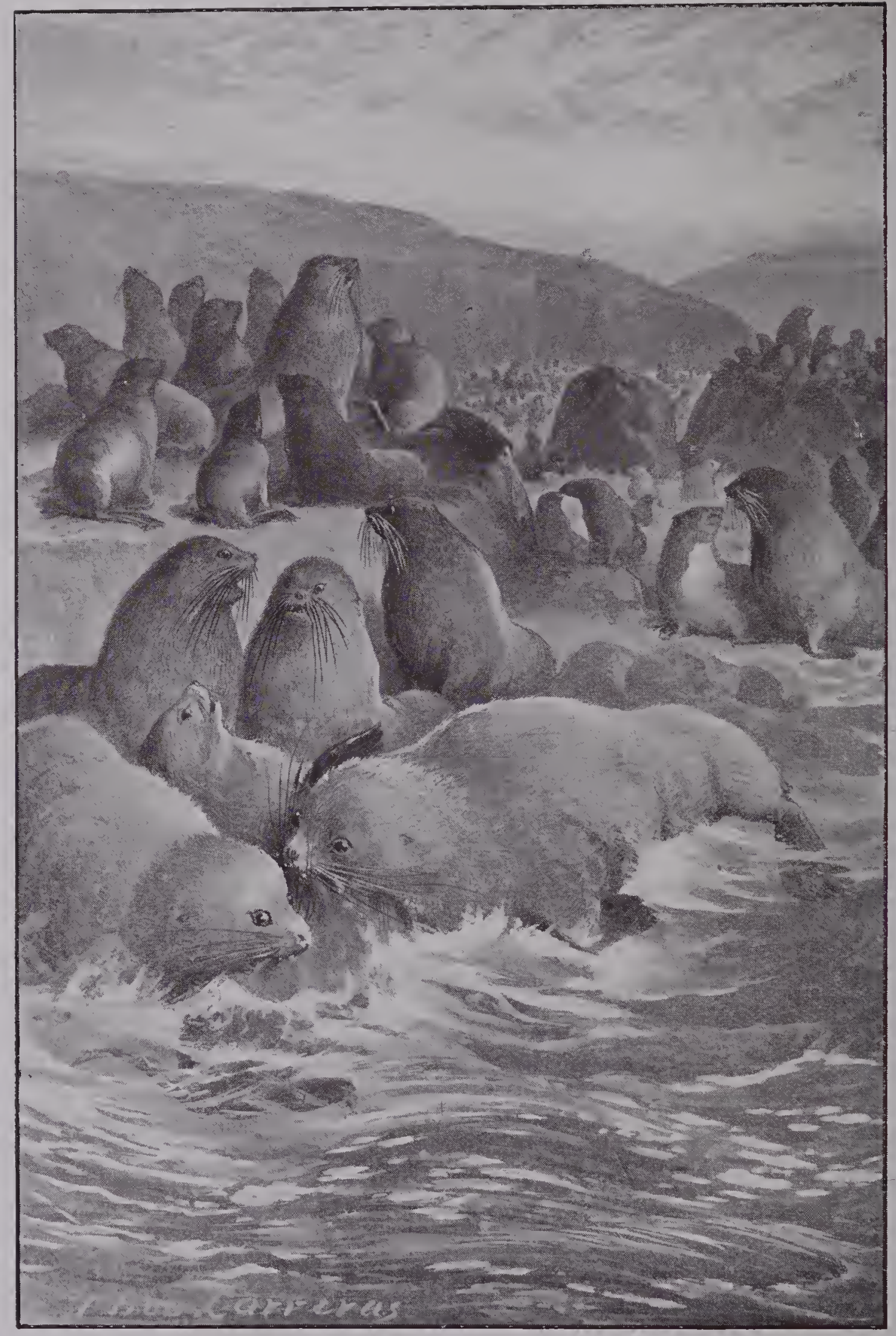

A FUR SEAL ROOKERY.

[To face p. 93 . 


\section{Seal Domesticities}

Now the happy proprietor ot a harem must keep close and careful watch, less prowling Lotharios should steal one of his hardly won wives, or lest any discontented spouse should venture to creep away. But even the tremendous endurance of the male Seal has its limits, and it frequently happens that, exhausted by his privations and exertions, a husband will find some cunning rival come in and eject him. Then there is nought for him to do but to go to sea again and endeavour by steady attention to hunting to make up for the stamina he has dissipated in the late riots.

Meanwhile, the baby Seals arrive. They receive little attention from their mothers, who listlessly allow them to gorge themselves on the rich milk and thrive amazingly. As for the males, they take no notice of the pups whatever, seem indeed to be unaware of their presence. By-and-by the young Seal or floe-rat must be taught to swim-another amazing thing about this wonderfully interesting creature. All land animals, except man, swim instinctively if flung into water even when just born. But the Seal, than whom no more graceful and enduring swimmer lives in or out of the sea, must needs learn laboriously how to comport himself in the water. And his mother teaches him. Of course, he is an apt learner, as all young animals are of what their mother has to teach them.

As he grows older he and his thousands of comrades get away from the colony by themselves and play, gambolling about all day long, only journeying from the playground to the sea and back. What they live upon after they are weaned until the whole colony goes to sea again is not known. Those that are killed and examined never seem to have anything in their stomach but stones. And it has been well established as a fact that, upon the arrival of the colony at their ' rookery:' 
all the fish in the neighbourhood take the hint and go away. But at last there comes a time when a general move is made seaward, and soon that densely thronged patch of land, where the noise had been so deafening that one can only liken it to the noise of two express trains passing one another in the tunnel, is wrapt in primeval silence, only the occasional sullen boom of a breaker, or the scream of a lonely sea-bird, punctuating the stillness.

Now begins the truly happy time of the Seal's life. That stormy four months ashore for the parents, and incidentally for the young ones also, has passed like a hideous nightmare, and the beautiful free life of a deepsea denizen is before them. They roam singly whithersoever they will all over the free ocean, feeding, ever feeding from the bounteous store provided for them. When weary they sleep upon the surface, and I have often in the North Pacific passed them so sleeping, rocked in the embrace of the curling waves, hundreds of miles from land. No one really knows how far they go, how wide their range is during the eight months they are away from their birthplace. But it seems difficult to believe that they ever pass through the tropics, having such a rooted objection to warmth. Of course, there are several kinds of Seals who frequent the temperate zones, notably the protected rookery on the Farallone Islands, so near the city of San Francisco that one of the attractions offered to visitors at the Ocean House is that they may sit on the verandah and watch the free gambols of the Seals.

Of course the Seal has enemies, stealthy and voracious. The killer whale, for instance, has an uncanny habit of slipping up upon a sleeping Seal and swallowing him at a gulp. One grampus, indeed, stranded upon the Californian coast, and cut up by a 


\section{Sealing Horrors}

party of 'longshoremen, was found to have a nice little family of fourteen tull-grown Seals in his capacious maw. And it is highly probable that he came to grief through chasing another one which fled ashore on a falling tide. Sharks, too, are apt to take toll of an unwary or sleeping Seal, turning noiselessly beneath them and taking a huge bite out of them, as they are wont to do out of a fish. But when it is remembered that the Seal is gregarious only while ashore or on the ice, it will at once be seen that the toll taken of them by these voracious sea monsters is after all very small. The white bear gets a few Seals too, but not many compared with the enormous numbers of them that may be seen lying about on the ice.

The one enemy which counts is man. I do not propose to harrow my readers' souls by describing the method of slaying Seals for market, not only for the valuable seal skins which adorn our ladies in winter, but for the oil and leather. It is a sordid, horrible business, which cannot be written about nicely. There is a grim and bloody reality about it that horrifies. For my part I shall never forger Burn-Murdoch's cry of horror in his book, Edinburgh to the Antarctic, where he speaks of the newly flayed Seal lifting itself redly towards heaven in the glowing sunshine as if asking its Maker why this thing should be. The seal-fishery is, no doubt, apart from its horrible and unnecessary brutality, a terrific business for man to engage in. Whether in the howling Antarctic, among those stern rocks of South Georgia or South Shetland, or in the Arctic among the ice-floes, it is a test of man's capacity to endure that has probably no equal. Every day death in his most awful forms must be faced. Filth, stench, hunger, and blighting cold must be met as part 


\section{6}

\section{Seals}

of the day's work, until the very meaning of the word comfort is forgotten.

And the pay? Ah, well, as it always is unfailingly, the rewards go to those who have done nothing but loll easily at home in luxury. Lady, with the hundredguinea seal-skin coat, know for a certainty that the men who looked death between the eyes and brutalised themselves lower than the shark to wrench that coat of yours from its rightful owners got less than a hundred pence for so doing. The bulk of that money went to city magnates and full-fed speculators who never gave its origin a second thought.

Of late years the indiscriminate slaughter of Seals having threatened to exterminate them entirely, a good deal of diplomatic intervention has taken place for the purpose, first, of giving the Seal a close time, and, secondly, of protecting the immature Seal. But it is a difficult thing to control men who become so lawless as seal-hunters do from the nature of their calling, and I fear that as far as the fur Seal is concerned, at any rate, the day of his extinction is not far off.

Remains only to note the extreme intelligence and teachability of the Seal. Most of us are familiar with this beautiful creature in Zoological Gardens, where its restricted quarters cannot conceal its wonderful grace. Some of us too will recollect a group of trained Seals taught to perform on musical instruments, play football, etc. But none of us who have seen the Seal at home, and have revelled in Kipling's inimitable story of Kotick's career, will need any reminding that in the Seal, no matter of what kind, we have one of the most wonderful, amiable and intelligent of all God's creatures, whether ashore or in the deep sea. 


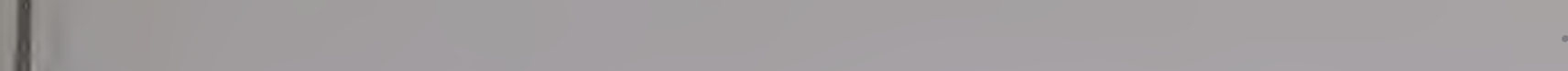




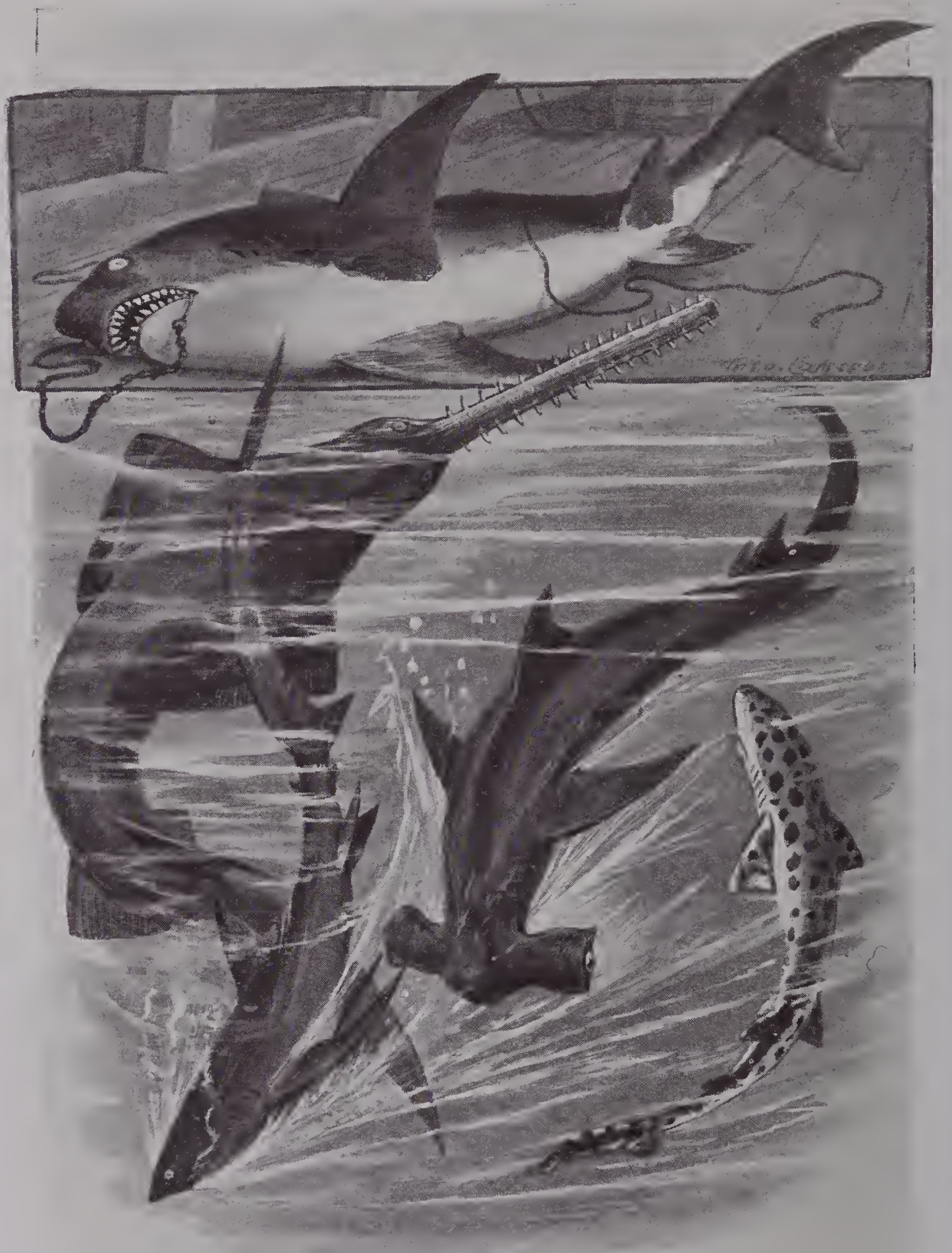

SOME TYPICAL SHARKS.

[To face p. 97. 


\section{CHAPTER $\mathrm{X}$}

\section{THE SHARK}

DASSING from sea mammals to fish proper is a momentous step, and merits a little introduction, in any case. But when one must begin the fish section with Sharks the introduction becomes imperative. For the Shark is in some respects a sort of connecting link between the mammal and the fish. A true fish, the Shark has yet the family or parental instinct of which nearly all other fish are destitute, a notable exception being the stickleback of fresh water, which does love its young. Another curious characteristic of the Shark family throughout its numerous branches is that it has no bones. Only cartilage. From the Basking Shark as big as a grampus, down to the skate, not a bone among them.

Another peculiarity of the Shark tribe is the stigma attaching to them, whereby the word Shark has become a synonym for a murderous thief, a creature without feeling or honour or repentance. I hold no brief for the Shark, but justice is justice, and certainly the Shark has had meted out to him nought but injustice throughout the years. Whether at this time of day it is not a forlorn hope to expect justice to be done to the Shark is another matter, and one upon which I express no opinion. I only know that amid the many fantastic Shark stories extant, based upon utter ignorance of this wonderful citizen of the Deep Sea, his habits and his 
usefulness, it seems well worth while inserting a little truth. Which is what I propose to do.

Let it be admitted at the outset that the Shark is not beautiful. In colour, no matter what branch of the Squalidae may be represented, there is always an absence of any tint pleasing to the eye. A dirty grey or dirty slate colour alternating with livid white is the prevailing shade of the Shark, and even the stripes of the Tiger Shark are not, as one might suppose, of the deep rich colour of the animal from which the name is taken. As to shape, the same strictures may apply. Unbeautiful in any case must be the verdict, most emphatically so when we come to the Raiidae, or Skate branch of the great family.

Then all Sharks have a sinister, villainous appearance from the shape and position of their jaw, and the cold deadly expression in their eyes. Especially is this the case with the least known of the family such as the Thresher, and the Sawfish (Pristis). One of the most awful-looking of occan monsters, although I believe quite harmless to man, belongs to the Raiidae, the Giant Skate or 'alligator guard' of the Mexican Gulf, known locally by the sinister sobriquet of Piscau del Diablo, or devil-fish. And as if all these disadvantages were not sufficient to load the poor creature with, hundreds of yarns have been invented, published, and incorporated in authentic natural histories concerning the Shark, of which it is only stating the barest fact to say that not one per cent. of them have a grain of truth in them.

Let it be admitted also as part of the indictment of the Shark, that he is an eater of human flesh, and does not always wait until the subject is dead. But what fish is not? It cannot be too clearly understood that all fish are omnivorous as regards flesh or fish, 


\section{Justice for Sharks}

nothing comes amiss to them, any of them. But to single out the Shark for opprobrium on this head is absurd, as absurd as is the invention of such idiotic stories as the Shark following a ship at sea because on board there is one sick. Much better to recognise in the Shark an evidence of the eternal wisdom of God, Who has here provided a race of large creatures in the sea possessed of an amazing appetite and absolutely indifferent to the quality of the food they eat, except that it must be flesh or fish-living or dead matters nothing. And in the agony of hunger, for agony it must be, they do not always stop to make sure that what they are swallowing is succulent flesh. I have seen a Shark swallow a bag of cinders flung overboard purposely. Consider how great must be the torment of an appetite that can thus drive a carnivore to so bitter and unsatisfying a morsel.

Now, having stated briefly what can with truth and honesty be said against the Shark, let us consider him a little more closely. And in order to do this it will be necessary, I think, to use a little imagination, yet imagination restrained by fact.

At the base of that great mountain in the South Atlantic, whose summit is named on the charts Fernando do Noronha, there lay side by side in the cool gloom of that depth two ordinary Sharks. Male and female, husband and wife, they had enjoyed each other's society as only monogamous creatures can, and now the time had come that they must part. For the rule of the Shark tribe is sulitary hunting, or if crowds gather at a banquet, all ties for the time are merged in the one overmastering desire for food. Whether they would ever meet again troubled them not at allwe are the only creatures of God's great family who are troubled about the future-but thev felt bitterly the 


\section{0}

\section{The Shark}

present pang of parting. They lay side by side all silently, with fins and tails gently vibrating and conveying all that they needed to express between them. Suddenly the male Shark gave one great sweep of his tail and was gone. Yet not so swiftly but that a bright blue spot behind him had darted forward and taken up its station just above his broad snout as he steadily plunged southward toward the roaring forties.

Only a little time elapsed, and then, sedately as became a matron with growing responsibility, the lady Shark got under way also and proceeded due east. And in like manner as at the departure of her husband a tiny blue form shot out from the shadows behind her and took up its station over her broad nose. She was a fine specimen of the Common Shark, about nine feet long with a dark grey skin and a dorsal fin (gafftopsail of the sailor) that when she neared the surface stook up nearly a foot out of the water. Her head was eighteen inches across and the upper lobe of her tail was nearly two feet long, with an auxiliary fin on it six inches deep. She was six years old, and had been round the Cape of Good Hope as many times as she had years of age, and yet she was entirely dependent upon the goodwill, fidelity, and skill of that tiny blue thing which kept its position above her nose without any apparent movement as she steadily made her way to the east.

It was a 'pilot' fish, one of the most beautiful as well as one of the smallest of the Scombridae, the great mackerel family, unique, horyever, in its strange love for the society of the Shark and its self-constituted pilotage of that great fish. Here, in parenthesis, I would remark upon the strange way in which men's minds are constituted. The fantastic tales about Sharks before noted will be accepted without a boggle 


\section{A Strange Companionship IOI}

by the very men who will scornfully reject absolute facts concerning the pilot fish's relation to the Shark. I do not know why, nor do I think any one does. For there are thousands of facts in natural history as well authenticated as sunrise and sunset, far stranger than is this bond between Shark and pilot-fish, concerning which I shall only use facts of my own observation, and none whatever of hearsay.

The strangely assorted pair proceeded in symmetrical order for some hours upon a course as definite as if laid down on a chart and steered by compass. And while they were thus wending their way together so harmoniously let us consider briefly the pilot-fish, since apart from his association with the Shark he has little interest for us. A beautifully shaped little fish, marked with transverse bands of blue and gold - the blue of that intensity seen only in fish and tinted to show against the blue of the sea. A pair of golden-rimmed eyes keep unwinking watch ahead, and the golden finsdorsal, pectoral, ventral, and caudal-seem as if frozen stiff, so rapid are their vibrations. A fish built for speed, but one of the feeble folk of the deep sea, for he is only about eight inches long. But why, oh why does a pretty creature like that attach itself to the Shark? As the Spaniards are so fond of saying, Quien sabe? Here the answer is, must be, that nobody knows, nobody can know. We must take the facts as we find them, and be as contented as we can.

Suddenly, like a flash of blue light, the little fellow has left his station. So swiftly has he sped that the eye can hardly follow him. He reaches a huge mass of seaweed, goes round it, and returning, visits first one side of the Shark's face and then the other, then resumes his station just over the nose. Now, during the time of the pilot's absence the Shark has never 


\section{The Shark}

swerved from her course, has neither accelerated nor diminished her speed. Apparently she has perfect confidence in her little blue attendant. And who, possessing any observation whatever, can doubt that on his return from his scouting journey the pilot has in some mysterious way conveyed a message something like this: 'I smelt something good; went and had a look. Nothing but a bundle of seaweed with a few miserable little fry in it. No use to you.' I have always felt sure upon seeing such a manœuvre performed that in some way or another, I know not nor can I speculate how, a conversational message like that has passed from pilot to piloted.

On, ever on, by day and by night, through the clear sea not far from the surface, the strangely assorted pair proceed with occasional deviations on the pilot's part in chase of the tiny organisms upon which this little chubby mackerel lives. But, alas! for his huge friend, times are indeed hard. No corrupting mass of offal in the shape of some dead sea monster is found ; nothing at all to eat for two days with the demon of hunger savagely gnawing at that massive liver and goading the starving creature to frenzy. A floating log covered with parasitical sea growths and attended by a swarm of fish of many kinds, but principally dolphin, coryphaena, and skip-jack-another species of mackerelis passed within a mile or so. Pilot sets off at top speed to reconnoitre, Shark, unable to wait, follows, and reaching the object, launches herself fiercely at it tearing at the solid wood as if she would compel nutriment to spring from it. The attendant fish vanish affrightedly; there is no danger of any of them feeling those lethal jaws, being in speed and agility far superior to any Shask.

In a little while her rage moderates, a considerable 


\section{The Hunger Search}

quantity of gelatinous matter, mostly foot-stalks of barnacles torn off the log, have gone down into her aching maw, which it appeases, though it does not satisfy. When suddenly the little pilot, which has been flitting about at a little distance from its principal agitatedly watching her manœuvres, darts off to the southward, followed closely by the Shark. By what amazing powers of intuition or of sight this little creature knows that some miles away there lies a ship I do not know, I only know that such powers as enable it to be assured of such a presence at that distance it does possess. That it should know of the peculiar quality ships have of shedding choice morsels in their wake may be merely a matter of memory, such as most deep-sea pelagic fish have, making them seek and keep the company of slowmoving or stationary ships for many days at a time. Presently they come up with the vessel and pass under the shade of her broad bilge, sniffing at the smell she gives forth of something. Several of the Shark's poor relatives, the semi-parasitical Remorae or suckers, hastily detach themselves from the ship and dart away into the depths, compelled to action for once by the knowledge that otherwise they will immediately be devoured. Round and round the ship they go, the pilot, in a high state of excitement, darting to and fro between Shark and ship as if carrying perpetual messages, while the Shark's cold greenish eyes never cease their steadfast gaze upon that vast shadow which may presently yield something to eat.

Meanwhile, some of the sailors aloft have caught sight of that stealthy form gliding along beneath them, and, in spite of their modernity, feel cold chills creeping down their spines as they view the messenger, as they think, of evil. We are heirs of the ages, 


\section{IO4 \\ The Shark}

inheriting their wisdom, but, alas ! how many of us, partially instructed or careless of learning, and devoid of that most uncommon of all qualities, common-sense, find that we hold in mortmain an awful legacy of superstition and cruelty that has come down to us untinctured by any spirit of love, of mercy, or of progress! So these sailors do really believe that the presence of that Shark means that one of them will presently fall sick and die, or that one of them will fall overboard and be devoured, and that the Shark knows this, and has come purposely from he knows not what part of the ocean for this terrible bequest. And one of those sailors, a young man, awfully ignorant, steeped to the lips in superstition, which in the ignorant nearly always takes the place of Christianity, whether in a religious form or otherwise, trembles so that he misses his footing and, with a mad clutching at vacancy, falls a hundred feet or so into the sea. There is a wild running to and fro, a frantic tearing at boats' gripes rusted firm by months of disuse ; but before the boat is freed from her trammels, it is remarked that, calm though the sea is, our shipmate is nowhere to be seen. And the boat is not lowered-there is no need.

Far beneath the surface, the Shark is finishing her meal, the first really satisfying one she has had for three days; and who shall say that she does not feel grateful to some invisible, non-understandable Power who has provided it? But in the hearts of all on board there is a dull, solemn feeling of hatred for the unconscious scavenger of the deep sea who happened to be on the spot at the right time to eat a man who fell overboard and was killed by the impact of the water. So that when, next morning, again hungry, the Shark cruises around, great preparations are made to prevent this hideous, man-destroying monster from 


\section{Maternity v. Hunger 105}

committing any more crime. A four-pound piece of pork is stuck upon a great hook riveted to a foot of stout chain, which is secured to a rope strong enough to lift a ton. This is lowered over the stern and then splashed up and down once or twice. In a moment the little pilot is there, quivering with excitement, nosing the meat, darting off a little way and returning, with a curious undecided air. At last he vanishes, returning in another minute with the Shark following slowly. She comes up to the bait, turns slowly on her back, sinking slightly until the bait is just entering the glistening cavity of her mouth, and then the second mate, who has been watching her movements with almost feverish anxiety, being young, makes a grab at the rope, and the bait leaps out of the water.

The anxiety of the pilot at this strange phenomenon is almost painful to witness. He seems to know that all is not well, and his passing to and fro between the Shark and the newly lowered bait is like the glinting of summer lightning. For some time the Shark hesitates-that compact mass of pork is so tempting -but at last, as if suddenly making up her mind, Mistress Shark turns at right angles to the ship and hastens slowly away. A greater power than even hunger has called her, and next morning, at daybreak, sees her lying quietly upon the waves at the surface of the sea surrounded by sixteen Sharklets, among whom the pilot moves with a comical air of proprietorship. And they, the new-comers, take no heed of the busy, friendly little creature until, with a leap like that of a dolphin, he herds the lively group together and leads the way down the Shark's gaping mouth into the haven of refuge she provides for her young. It was only the advent of a hungry male Shark, a lithe sinister brute, who, to the mother, 


\section{Io6 The Shark}

loomed large as a veritable demon of destruction to her offspring, for, strange as it may appear to most people, the Shark is a most loving parent, and although she can only shelter her young within her body, not knowing how to protect them by fighting for them, she is nevertheless torn by anxiety on their behalf.

Now for many days she has no rest at all. With the solicitude of a mother-hen for her chicks, she watches over that group of Sharklings, shepherded by the pilot, whom they are rapidly outgrowing, sheltered in her bosom and fed; yes, fed, though often the mother feels as if vultures were tearing at her liver, until at last there comes a day when the youngsters, having grown sufficiently to take, and make, their own way through this watery world, leave her one by one and melt into the void, to lead henceforward an independent existence in that great ocean expanse, and the deserted mother seeks another mate who may provide her with a new family to suffer for and be deserted by in their due turn.

In the few preceding pages I have dealt with the Shark as if there were only one kind, although I did carefully mention that there were others of the same family. But, as a matter of fact, there are more varieties of the Shark family than of any other fish family living, with the possible exception of the mackerel. I have never been able to reckon up how many Sharks there are of distinctly different characteristics, but an enormous number there certainly are, all characterised by the one feature, that of enormous eaters of garbage. Sharks with wide mouths, armed with seven rows of teeth, each an inch long, and with triangular edges saw-toothed, finer than any surgical instrument ever made. Sharks with wide mouths, armed with fifty rows of needle-like teeth, 


\section{Curious Sharks}

the use of which one can only conjecture, and Sharks whose vast jaws are lined within with a sort of curious mosaic of pearly surface, as if the mouth were a mill in which could be ground or triturated the most obstinate substances. Indeed, the arrangement of inese palatal and labial plates in some of the Sharks is a matter for profoundest admiration. Nothing like it can be seen in any other animal in the wide world.

Then there is the wondrous Saw-fish (Pristis), a most amazing Shark, abounding in Eastern seas, who has grown from his skull, right out before him, a flat mass of stiff cartilage edged with ivory teeth, set at regular intervals of about three quarters of an inch. For some strange reason, which I do not pretend to fathom, this curious weapon has come to be confounded with the sword of the Sword-fish (Xiphias), which I have already described, and in country houses where there are one or two specimens hanging in the hall, the visitor is calmly invited to view the weapon with which ships are sunk! No one seems to consider that even if the saw (not sword) were made of tempered steel, instead of stiffened cartilage, it would be impossible for any force behind it to drive it into anything tougher than fat, because there is no point to it; a sort of snout, slightly turned up at the end, terminates it; and again, the saw-like arrangement of the teeth on each side of it preclude the idea of its being a piercing weapon. No, its function, though gruesome enough, is not that of sinking ships by perforating their bilges. This particular shark has a wide mouth, lined with from forty to sixty rows of infinitesimal, necdle-like teeth. He is a specialist in food, and although not averse to mumbling decaying carrion, should it come his way, has a pleasant little fashion of disembowelling 


\section{I08 The Shark}

fish by a push of his saw beneath them, and then nuzzling in the soft entrails, the only food that he really cares about. These Sharks grow to a length of fifteen feet and weight of a ton.

Then there is the Thresher Shark, with which I have dealt pretty fully in the chapter on the Mysticetus, the sole peculiarity of which is the abnormally long upper lobe to his tail, used as a sort of flail wherewith to beat the hapless mammal. Sharks of weird aspect but of no large capacity of mouth abound also in the great depths of the sea, and are only brought to the surface in a more or less mutilated condition, owing to the tremendous change of pressure during their passage upward.

But one of the most interesting of the Shark tribe is the parasitical or semi-parasitical Remora. This small shark (seven pounds weight is about their maximum) has an extraordinary arrangement on the top of its head (which is perfectly flat) whereby it can attach itself so firmly to any floating body as not to be detachable by any force applied except at the cost of rending the fish asunder-unless one knows the trick which the fish itself uses, in which case the creature is detached in a moment without difficulty, and darts off at a high speed to find some other host to which it may attach itself. A ship or a whale matters little, -its object is to be carried along in the immediate vicinity of food which it may obtain by merely opening its mouth and closing it at intervals. I have already noted the suckers' delightful quarters in the mouth of a right whale, adhering to the palate with its head pointed in the direction from whence the whale's food enters, so that it easily receives tithe of all without the slightest effort on its part to obtain it. So you shall find a whole family of Remorae attached to one 


\section{Appetite Extraordinary}

$\log$

whale-outside or inside matters little-all contented and happy in their utter dependence upon their gigantic host. Even certain huge specimens of their own race find them shelter occasionally, for Dr. Günther records an instance of a huge Shark of a harmless kind whose teeth were covered with membrane and who gave shelter in its mouth to a whole colony of Remorae. To this very queer fish he gave the name of Rhinodon typicus.

Of the voracity of the family generally I have already said a little, but I feel impelled to return to the subject for a briei space, because it is one that can hardly be realised by shore people at all. Let me try and express my meaning as simply and briefly as possible. We once caught a humpback whale in Vau Vau which sank as we were preparing to tow it to the ship, i.e. passing a rope through its lips. The sun had set and the swift tropical twilight had descended, so that we saw it was useless to attempt the long weary task of raising our spoil from the coral bed on which it had settled before daylight next morning. So one boat lay by the carcase all night-it was only twentyfive fathoms down-and watched with crawly sensations the brilliant bands of green light beneath, showing where the great scavengers came and went. It was a very long night, and many an inaudible prayer was put up during those hours of darkness, I know. At last day dawned and work commenced immediately. I need not describe the tedious process of raising a whale from the bottom by the aid of a couple of boats -it is a weary job. At last, however, we were gratified to find the great weight beneath becoming lighter and lighter until at last, with almost a bound, the huge body reached the surface. It was the centre of a host of ravenous Sharks, some of them as long as one of our 


\section{IIO}

\section{The Shark}

whaleboats, and all of them were tearing at the body as if they iad fasted for years and their first meal was now about to be taken from them. It had only been at their mercy for about eight hours; and it was half gone; that is to say, in that brief time these useful sea-scavengers had eaten about thirty tons of meat, blubber, and bone, and were now apparently as unsatisfied as ever. We started to tow, feeling that it was hardly worth while, and accompanied by an uncountable horde of the devourers, but after towing for an hour were compelled to let go, because we were drifting on to a reef. And I was right glad. I felt sure that by the time we arrived at the ship-another six or eight hours-we should have had only our labour for our pains.

A whole wealth of literature lies in the discussion of the Raiiae, those homely, shark-like creatures whose flesh is so highly esteemed by the London poor, where fried skate is a morsel to be delighted in when served up in penn'orths with crisp fried potatoes. The terrible Sting Ray of tropical seas, whose tail is a flexible rod set with razor blades secured diagonally, and is used as an instrument of correction by the South-sea trader upon his wives, ${ }^{1}$ and the no less terrible Alligator Guard of the Mexican Gulf, a fearsome monster some sixty square feet in area and with a peculiar twist for leaping out of the water after dark. One hardly knows where to draw the line in dealing with this extraordinary family of universal rangers of the deep sea ; the feeling will force itself in that not a chapter or so is needed, but a whole volume each, to describe the beings and doings of one fish family.

I dismiss as utterly unworthy of any notice whatever all the stories that have been told of the Shark's

1 Vide Louis Becke, By Reef and Palm. 


\section{A Plea for the Shark II}

innate ferocity and calculating devilishness. As I have often had the pleasure in saying, the Shark eats man, not because he loves man to eat, but because man when he falls overboard is usually easy to get. If the man be a good noisy swimmer, no Shark will venture near, for they are, though tormented with hunger, a most nervous and timid race, and, indeed, always seem to me to lose a great many opportunities through diffidence. I do not love the Shark in any of his varieties, but I do love justice, and so, in spite of my predilections against the Shark, I have endeavoured to write of him (or her) fairly, as I would wish to be written about myself if I were a Shark. I am very glad I am not.

A very large section of the Shark family live at immense depths. So it has been discovered of late years by the indefatigable labours of such men as Messrs. Goode and Bean, of the Smithsonian Institute at Washington, and the Italian professors who have made oceanic ichthyology their special study. But, unlike most of the deep-sea fishes, as opposed to the surface or near-the-surface fish, the Sharks do not confine themselves to the profundities. They apparently seek those mysterious depths to breedmany of them deposit their eggs in carefully adapted purses of toughened membrane so arranged that they will open of themselves at the right time, then, having provided for the continuation of the species as far as they are concerned, they return to the surface. Others again spend all their time in the depths, except when the family is coming, at which time they ascend into the upper and warmer strata. For it cannot be too carefully noted that below a depth of about a hundred fathoms the temperature of the sea is the same everywhere from Pole to Pole. The exceptions to this rule 
are the bursting-up places where boiling springs arise from subterranean fires and of necessity raise the temperature of the surrounding sea; or the outlets of submarine volcanoes fiercely struggling to assert their destructive power against the unthinkable mass of superincumbent water. Apart from these exceptions, the temperature of the sea below one hundred fathoms is about thirty-one degrees Fahrenheit, or just above the freezing-point of salt water.

But we are neglecting our Sharks, who, with an adaptability shown by no other fish, come and go between the surface and depths of four to five thousand feet. Especially the Rays, who in all their varieties are great travellers up and down, being found at all depths from ten to one thousand fathoms. And unlike the usual deep-sea denizens they do not acquire any very great alterations of physique; to be sure, the ordinary Skate is sufficiently hideous for anything. I vividly remember, when second mate of the 'Harbinger' in Table Bay, some twenty-two years ago, fishing for craw-fish with an improvised net made of spun yarn netted on to a big iron hoop. Feeling a great jerking at the rope, I called for help, and we hauled to the surface a Skate fully six feet across from tip to tip of his 'wings.' He was far too large and heavy to be hauled on board like that, so we harpooned him, and after a long struggle succeeded in getting him aboard.

He lay on deck, a thing of utter hideousness in form and colour, so much so that after gazing upon him for a little while, the repulsiveness of the creature made me feel quite ill. And the great mouth lined with teeth just like ours, opening and shutting convulsively, looked appallingly human. I was roused from my shuddering fit by the sight of one of the boys just 


\section{An Object-Lesson II 3}

offering to put his finger in the mouth. I pulled him away, and holding him by the arm, inserted a stick of wood an inch square into that quivering cavity. Instantly the jaws closed, there was a grinding sound, and the stick fell in two halves, bitten through as cleanly as a horse bites a carrot. The boy had learned his lesson. That Skate became the prey of the sailors, who much appreciated him fried, and although we had a fairly large crew there was enough meat on his wings to give them a good supper and breakfast.

Here we will leave the Sharks; for, although I have said practically nothing of the Dog Fish, I feel that there is not really sufficient distinction between them and the usual Shark to warrant any detailed remarks about them. The Dog-fish is just a small shark. 


\section{CHAPTER XI}

\section{THE TURTLE}

$\mathrm{H}$

ERE we come upon a deep-sea denizen that occupies an almost unique position among his fellows, in that he has no enemies but man. The exceptions being the sperm whale and the sea elephant, as I have before noted. This freedom from the fear of instant death at the mouth of a fellow-citizen is so unusual among the deep-sea people that when an exception comes it makes itself noticeable. But not only does the Turtle commend itself to us as unique in this respect, it is also one of the strangest of all the amphibia. The whales must come to the surface frequently to breathe, and we know fairly well upon what they feed. The seal cannot remain beneath the sea nearly as long as the whale, and his food is very well known; but the Turtle, in all his varieties, in all his ways, is mysterious beyond the power of superlatives to express. It does not seem to matter to him whether he stays beneath the surface for an hour or a week, nor does it trouble him to spend an equal time on land, if the need arises. He is neither fish, flesh, nor fowl, yet his flesh partakes of the characteristics of all three. Eating seems a mere superfluity with him, since for weeks at a time he may be headed up in a barrel (with the bung out) and emerge at the long last apparently none the worse for his enforced abstinence from food, from light, and almost from air.

His range is restricted to the temperate and tropical 


\section{The Turtle Pair}

seas, and is extended or contracted according to the season.

And, finally, as a close to this brief introduction, it may truly be said that of all the higher, warm-blooded organisms, there are none so tenacious of life as the Turtle. Injuries that would be instantly fatal to fish ever leave the Turtle apparently undisturbed, his power of keeping death at bay being nothing short of marvellous. Also, it is a matter for very great wonder how closely he is allied to the tortoises of the land, leading lives totally different to his, yet in all but a few minor details precisely the same in structure.

However, we must leave generalities and come to particular instances. There are two varieties of Turtle which furnish us with our most interesting examples, and it is with one of these that I wish now to deal, the Spharga coriacea, a common ocean Turtle frequenting the North Atlantic and Pacific, even as far north occasionally as the coast of Britain, and attaining a weight of one thousand pounds. A pair of them lay basking in the blazing sunshine of the northern tropic, nearly midway between Africa and America. Their broad carapaces shone in the sun's glare like burnisher gold, and occasionally they lifted their heads out of the sea and gazed around as if in search of something. But the fact is that they were ill at ease.

The female felt the need laid upon her of making for a familiar spot she knew of to ease herself of that load of eggs she carried, and the male, while hating to part with her, felt an almost equally strong desire to remain where he was. Such food as he needed was abundant, passing ships were few, and they were the only things he felt any fear of, so with the usual selfishness of the male he found a grievance in that his partner must leave him. Their communication of ideas and views 


\section{II6 The Turtle}

lasted all night, though to the human eye they were just a pair of sluggish Turtle lying side by side in profoundest silence, and without a movement, save that imparted to them by the tiny wavelets of that quiet sea. As the dawn broke she turned her head westward as if by some irresistible impulse, her four broad flippers swayed with a rhythmical motion, and she darted forward, transformed instantly from an image of slothful ease into an embodiment of superabundant energy, cleaving the blue waves at the rate of about eighteen miles an hour. No one who has not seen the Turtle in a hurry can possibly understand how so apparently clumsy a creature can cleave the waves at such a rate. It is a revelation of the methods of Mother Nature.

But she is gone, and Mr. Spharga remains basking alone. We can only guess at his feelings at being thus deserted, knowing nothing of the imperative maternal claims swaying the movements of his spouse. Hour after hour passes, and still he lies motionless, his back just awash, and his head sunk beneath the surface, his eyes closed, and his four broad paddles hanging down motionless.

'Captain James, there's a fine Turtle asleep just a little on the port bow. We're hardly movin,' don't you think we might lower a boat and see if we can't get him ? I know just the trick of it. I've harpooned lots of 'em in the South Pacific when I was whalin' there.'

'All right, Mr. Smith ; go ahead and wish you luck.'

The fine old barque is rounded to (there's hardly enough wind to do it) and the brisk young second mate, infecting the members of his watch with his own enthusiasm, gets the boat in the water in about ten minutes. He takes the harpoon which he has properly bridled long ago and whispers instructions to his crew how to paddle quietly and obey the wave of his hand. 


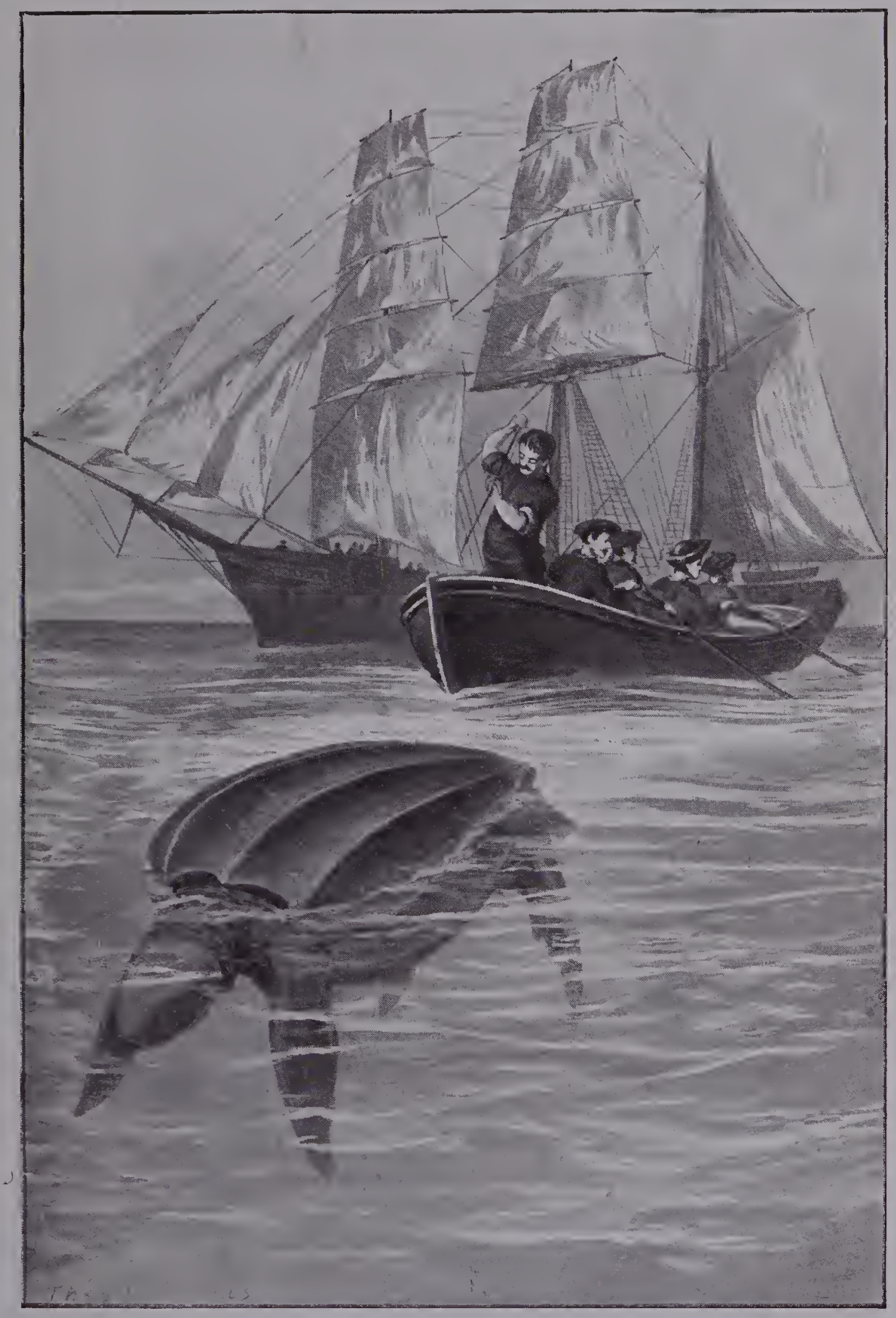

HARPOONING A SLEEPING TURTLE.

[To face $p$. II 



\section{Homeward Bound}

They creep up behind the dozing, listless, and deserted Spharga, the second mate rises stiffly to his feet, raises his iron and crash! it has pierced calipee and calipash, nor can any struggling on the part of the impaled one release him from that terrible barb. A considerable wrestling ensues before the massive prize can be hoisted into the boat, but it is effected without a capsize, and presently, flushed with his triumph, Mr. Smith reports himself to his skipper and the treasure is handed over to the cook.

Meanwhile the fleeing spouse is making record time towards her objective. Swimming just beneath the surface she makes no ripple above, only a broad band of light marks her passage, and all the hungry sea-people, attracted by the glare, make respectful way for her. They are ravenous, but she is invulnerable. The broad fans of her paddles beat upon the sea with a regularity akin to that of the propeller of a steamship, and apparently as untiringly, until on the second morning she reaches the shining beach on one of the Grenadines which she has all along been aiming at, guided by that mysterious homing instinct of which mere humans know nothing. A tiny surf curdles round the snow-white sand, a golden globe hangs in the sapphire sky, when alone, and amid a perfect silence the great Turtle drags herself cumbrously up just beyond high-water mark.

This is one of the secret places of the Almighty. Far from all the iniquities of man's devising, here is only beauty and peace as at the dawning of creation when first the new-made earth arose from the enlightened sea. Only a few timorous little birds watched the upward progress of the Turtle, and expressed their disapproval of her intrusion in quavering notes hardly audible. Suddenly stopping, she changed from a lethargic weariful attitude to one of furious activity. 


\section{8 The Turtle}

The four flippers fling themselves as they did on the passage, the sand flies around in a dense shower, almost like a fog, until the central toiler is hidden from view. When at last the smother subsides she is down in a pit of her own digging and the work of egg-laying has begun. It lasts for two days, and then carefully clambering out of that sandy hole where snugly lie one hundred and fifty round white eggs, the weary mother devotes her remaining energies to filling in the pit, burying her treasures beneath a foot of loose sand. This completed she lumbers painfully down to the sea and launches herself into sublime peace on the bosom of the universal mother, her task well done, her rest well won.

Day by day the great sun sheds his life-giving beams upon that spot where, covered in beneath undistinguishable sand, lie the family of the Turtle. Does she wonder what has become of them? Do the fish who shed their roe in uncountable millions ever feel a pang of maternal care? Who can tell ? The mystery of motherhood is so profound that one does not care to speculate. For instance, I have a hen who has just hatched a brood of ducklings. As best I can I have isolated her in a spacious wire-fenced run from the many enterprising chicks which are running loosely, about a hundred of them. In spite of all my care these chicks do get in with the ducklings and the mother-hen, generous creature, forbids them not, allows them to share her food, and when I drive them out, sets up an outcry as if they were her very own. But one day last week one of the ducklings got out, how, I cannot imagine. I went at once to put it back, but, oh, the agony of the parenthen! With widespread wings and gaping mouth she hurled herself at the wire fencing where I was picking up the squeaking flat-footed alien she had been cajoled into nursing. Had she been free, I know she would 


\section{The Beginnings of Turtle II9}

have flung herself upon me with heroic carelessness as to the result. And the youngster was not merely not her own, but belonged to a totally different species! Oh, the wondrous mystery of motherhood! Who dare attempt to define its limitations?

Many days the sun shines upon that patch of sand, until one morning there is a series of shiny upheavals, little cones erected on the smooth surface. And presently there emerges from the broken-up level a tiny black Turtle about an inch across. Perfect in every detail to the eye, but if you handled him you would find his shell quite soft. With amazing swiftness and guided by God-given instinct he scuttles down to the sea. A gentle wavelet greets him, lifts him to its bosom and he is launched. No weight of family ties oppresses him, he does not know his brothers and sisters swarming after him along the same road, but he does know what his first duty is - to seek adequate shelter. In his little brain there is implanted a streak of caution, based upon the fact that up till a certain period his protecting armour is soft, no defence against hungry fish. What then is he to do in order to live? He has no one to teach him, no parents to guide. Here instinct, that amazing principle which I prefer to consider the guidance of an omnipresent God in all His creatures, comes into play. Closely clustered around these shores the gulf-weed (Fucus natans) grows in tropical profusion, holding within its branching fronds an astounding abundance of marine life. And our little Turtle, feeling his defencelessness, hies him into the heart of one of these weed masses, being presently joined by some of his relatives whose instincts have led them close after him!

Here for a blissful season the baby Turtles, all untended save by the all-knowing Intelligence, gather 
and grow. Here they feed unmolested, and know that their armour is hardening apace. Outside the little patch of weed-enclosed sea they know that there is a horde of hungry monsters waiting for them. But they care not. Never until fully protected by their natural armour do they knowingly leave those cheerful foodful precincts. Yet it is true that occasionally straying too near the thin edges of the submarine forest, a baby Turtle does get gobbled up by a hungry fish. And why not? Paucity of imaginative power alone prevents me from depicting the reign of terror inaugurated in that scanty weed-space among its smaller denizens. How can we live, I can imagine them crying, when deep down in our most cherished fastnesses come these black ravenous interlopers devouring us?

Here we must pause a moment to remember that in the sea the interdependence is absolute, direct. Every creature lives upon some other creature below him (above in some few cases as yet but vaguely determined), and we are horrified to see the incessant warfare that is waged. But, to use an historic phrase, 'let us clear our minds of cant.' Is not this just as much a feature of the land as of the sea? Do not all living things of food value compulsorily contribute their bodies to our upkeep ? Excepting of course the vegetarian members of society, who prefer to take their animal food-contribution at second hand. But we stray from our Turtle. Presently he finds out that his carapace is hard, and constitutes a perfect shelter against all enemies, save those whose mouths are large enough to take him in entire. And so ere long he bids good-bye to the little weed-patch which has sheltercd him so long, and starts upon his voyage of life over the trackless ocean.

Now it does not appear with any degree of accuracy 


\section{Mysteries of Growth}

what the Turtle, the Edible Turtle, lives upon during his adolescence. There be Turtle who are known to live upon strange foods, but in every case they are a sort of compromise between Turtle and tortoise, or even Turtle, tortoise, and lizard. Of these are the Emysaura serpentina, dwelling in and around Oriental lakes and rivers, and living indiscriminately upon small fish, reptiles, and even small birds. The Gymnopus of African rivers feeds, dear creature, upon young crocodiles, and evolves from that uncanny diet most delicate flesh, which, albeit it is strongly flavoured with musk, is most highly prized. But the Thalassians, or true Sea Turtles, may eat fish alive or dead, or they may eat certain kinds of weed ; all we can say is, that we do not know what they eat nor how long they can fast, except that from the time a Turtle has been 'turned,' say, on a Jamaican beach until it has been converted into soup for a Lord Mayor's banquet in London, it eats nothing, and does not seem any the poorer for it.

Being of a lethargic habit, of course there is not much waste of tissue. Having assisted at the butchery of many Turtles just from the sea, and examined, as was always my wont, the contents of their stomachs, I have never found anything identifiable therein, except a few stones and cuttle-fish beaks, which latter looks as if the Turtle, like nearly all other sea fish and mammals, eats cuttle, but is not proof positive. And, beside, the squid is so plentiful in some weed-covered spots of ocean, that if the Turtle grazed upon the weed he could not help eating many cuttles at the same time.

But, whatever our young friend eats, and wherever he eats it, one fact energes; it agrees with him immensely. He grows apace, his horny covering growing, too, since he does not cast it like the crustacea : he leads 
an exceedingly pleasant life, basking in the tropical sun, or cruising leisurely in the cool depths free from all danger, when once he has attained a weight of about five-and-twenty pounds, which is within the first year usually. After, no fish or mammal, however ravenous, however well armed with teeth, interferes with the Turtle; he is the chartered libertine of the ocean. When once he has withdrawn his head from its position of outlook into the folls of his neck between the two shells, intending devourers may struggle in vain to make an impression upon him, but will always fail.

Now, this being the case, and considering the fecundity of the Turtle (I counted over eight hundred eggs once in the ovary of a Turtle turned by us in the Gulf of Mexico), it seems strange at first sight that they are not almost as plentiful as cod. So I believe they would be, but for the fact that they lay their eggs where they do, covered with a comparatively thin layer of sand, and exposed to the ravages of many creatures, notably rats and birds and crabs. Many a rich banquet do these burglars have upon the fat mound of eggs deposited by Mother Turtle, and it would be unpardonable oversight on their part to leave even one egg. This, of course, accounts for a great many. As for the toll that man takes, as in the case of nearly all deep-sea fish, it may be neglected in taking into account the number of Turtle which do not die of old age. It may be taken for granted that what man gets of any deep-sea fish, by comparison with what is eaten by the sea-people themselves, is but as the crumbs of the banquet, the skimming of the pot. But, by the operation of Nature's own laws in thinning out any superfluity of any creature anywhere, the Turtle is kept from becoming too numerous, harmless as he is. No one really knows how large a Turtle may grow, but certainly there does not appear 


\section{Turtle as Food}

to be much, if any, exaggeration attached to the statements of Pliny and Strabo, who, describing the Chelonophagi of the Red Sea, say that they utilised the shells of the Turtles they had eaten as roofs to their huts, and boats for their feeble voyages.

Strange to say, the handsomest Turtle, the Hawk'sbill variety (Chelone imbricata), furnishes the worst flesh, being so strongly flavoured with musk as to be almost uneatable. This peculiarity would seem to point to a diet of squid, since these mollusca are exceedingly musky. But it may not be out of place to remark here that Turtle flesh, even of the best sorts is not nice. As Sam Weller's pieman hoarsely whispered, 'it's the seasonin' as does it.' A diet of Turtle steaks, or of hashed Turtle, or of 'Turtle soup, au naturel, would soon sicken any one but a savage. For sixpence, or its equivalent, in most of the West India Island towns one can get a heaped plate of Turtle steak, with bread or yams or sweet potatoes ad lib. But I never knew even a hungry sailor that wanted more than one meal a week of it, for all its cheapness.

The fact is that, in the cult of Turtle soup, we are following (a long way off, it is true) the example set by the Chinese, who love gelatinous soups, and pay fabulous prices for the nests of the sea swallow, the Holothuria, or sea-slug, and sharks' fins, simply because of their gelatinous qualities. Yet, strange to say, they do not put the same value on the Turtle as we do. Turtle are many in number on the Chinese coast, and the guileful Chinese fisherman has developed a splendid plan for securing them with little trouble to himself. He captures some Remorae, those little sharks that are so lazy that they have developed a sucking arrangement on the top of their heads, whereby they may, and do, attach themselves to anything that is likely to float 


\section{4 \\ The Turtle}

then into the vicinity of food to be obtained without effort. Carefully he welds a ring round their tails in such wise that it cannot be pulled off, and to it he attaches a thin, strong line; then, putting out to sea with six or seven of his unwilling helpers attached to the bottom of his sampan, he gets a good offing, and waits patiently for the appearance of a Turtle asleep upon the sea. As soon as his keen eyes have detected one, he paddles noiselessly in that direction until, getting near enough, he ships his paddle and, with a long bamboo, pushes off one or two or more of his Remorae. Now all he needs to do is to keep them from fastening on to the canoe again, for they speedily discover the Turtle and attach themselves to him. When they have done so, the quaint yellow fisherman in the boat needs but to haul in, for you may, by pulling upon a Remorae from aft, tear him in two pieces, but you cannot make him let go his hold. And so despite his struggles, the poor turtle must come, and presently yield himself to be made soup of for the delectation of some 'number one' mandarin. This is also the method pursued by some of the coast tribes of Eastern Africa, whose appearance would seem to give the lie to any suggestion of such a standard of intelligence as would utilise the Remorae in so ingenious a way.

Our method, if I may call it so, of capturing the Turtle is much less elaborate. Certain places are known to be favourite haunts of the Turtle for egg-laying purposes. Then all that is necessary is some safe reservoir where the captured creatures may be kept awaiting shipment, and a band of labourers who do not object to night-work. When there is a good moon, not necessarily full, we hide ourselves in convenient quarters adjacent to the beach, and wait more or less patiently until we see the first broad back, glistening in 


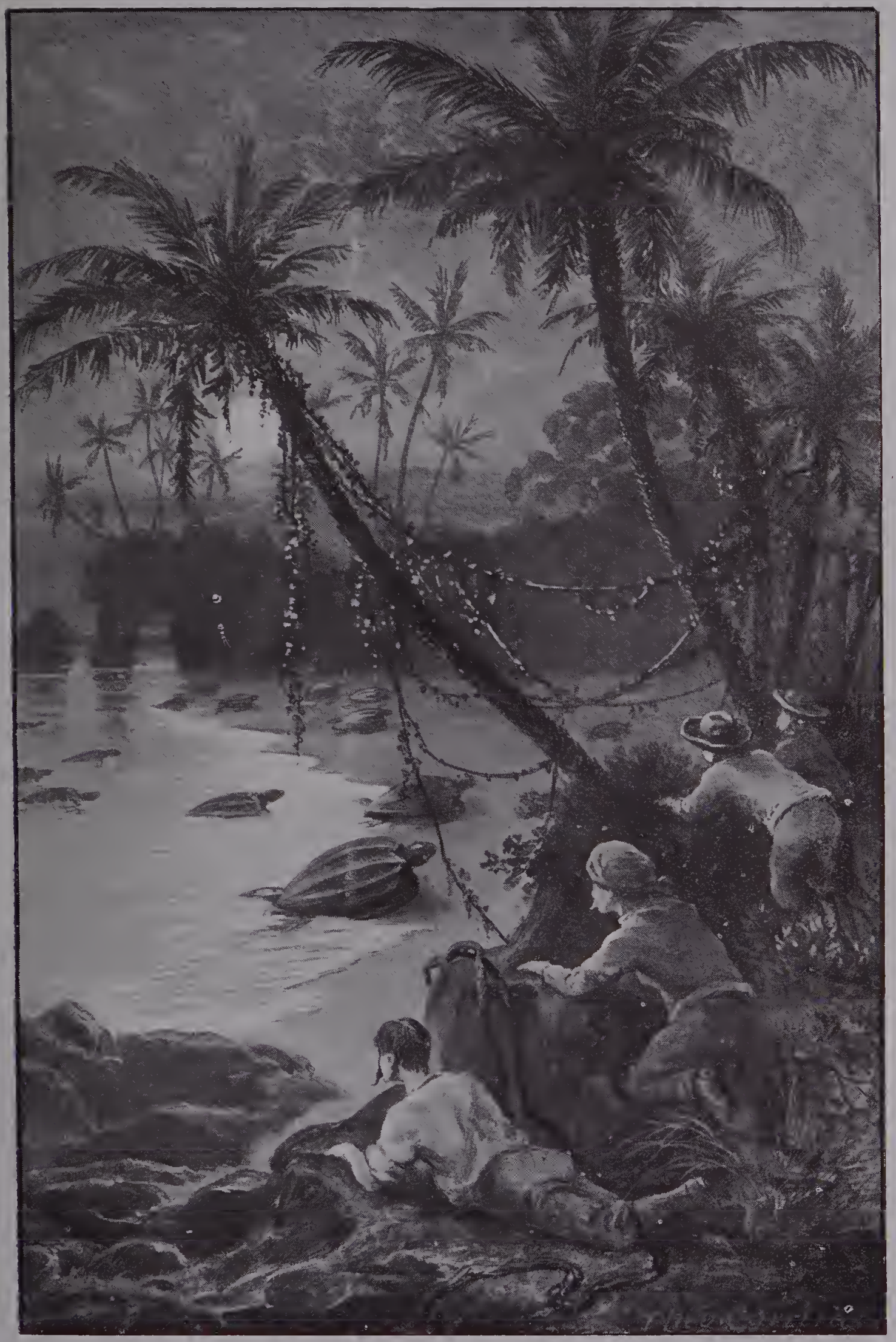

AVAITING THE TURTLE.

[To face $p$. I24. 



\section{Turtle Turning}

the moonbeams like a silver shield. emerge from the waves. The excitement becomes intense; one feels one's muscles crawling, as it were, so eager are we to pounce upon our prey. But we must not, yet. The first arrivals have fallen to digging and surrounding themselves with a halo of fine sand, and others are coming every few minutes, on the same errand bent. At last, when the long stretch of beach is fairly covered with the toiling Chelones, each in her own pit, labouring to make the receptacle sufficiently deep for all the eggs she has brought, our chief gives the signal, and, like a band of brigands, we all rush forth between the Turtle and the sea, and halting one by one at the pits, strive to turn the Turtle over by a dexterous twisting of the hind flippers. Sometimes, and that not seldom, we get hold of a Turtle that it would take three men to turn over, and, holding on frantically, we are dragged down through the blinding sand to the sea marge, where we must let go or be drowned. Presently the captured turtle, lying with feebly waving flippers on their backs quite helpless, are towed by ropes attached to them to our reservoirs or ponds, where they await shipment to London. And from thenceforward, until the chef draws his knife across their leathery throats, the Turtle fasts. Never has he been known to eat in captivity.

One point more in connexion with the Turtle before we close this all-too-brief memoir. It is his amazing vitality. Most of the deep-sea folk possess this quality of tenacious hold on life in a high degree, but none, as far as I know, to nearly the same extent as the Turtle. Without endorsing any such foolish remark as that 'they cannot die until the setting of the sun,' I can truly say that I have seen the flesh cleared out of a turtle-shell and hung upon a tree, where for hours the 


\section{I26 The Turtle}

quivering, convulsive movement of the muscles went on. Not only so, but on one occasion only the head and tail were left attached to the shell. Some time had elapsed since the meat had been cut out of the carapace, and no one could have imagined that any life remained in the extremities. But a young Dane, noticing that the down-hanging head had its mouth wide open, very foolishly inserted two fingers between those horny mandibles. They closed, and our shipmate was two fingers short, the edges of the Turtle's jaws had taken them off clean, with only the muscular power remaining in the head. Then another man tried to cut the horny tail off, but as soon as his keen blade touched it on the underside, it curled up and gripped his knife so firmly that it was nearly an hour before the blade could be withdrawn. Yes, the vitality of the Turtle is unique, and but that it has been so firmly established and frequently experimented upon, stories of it would have to be listened to with an utter incredulity. Signor Redi once cut a Turtle's head off, and noted that it lived for twenty-three days without a head; and another, whose brains he removed, lived for six months, apparently unconscious that it had suffered any loss. This points to a very low order of being, since such indifference to pain and deprivation of members is characteristic of the lowest organisms. Yet the turtle is a highly developed creature. 


\section{CHAPTER XII}

\section{THE CUTTLE-FISH OR SQUID}

W

E now come to the consideration of one of the most widely distributed, most useful, and withal most extraordinary of all the denizens of all the seas, the curious shell-less mollusc known generally as the Squid. For some strange reason, which I do not pretend to fathom, an enormous number of otherwise well-read people profess knowledge of him under the name of Octopus. Now it should be known that the Octopus is a very humble member of this great molluscan family, never growing very large, and entirely indebted for his fame to the splendid but fatally inaccurate pen of Victor Hugo in the 'Toilers of the Sea.' If high art in fiction be to clothe the utterly impossible as well as improbable in such fascinating language that the reader shall be crammed for the rest of his life with absurdities, then Victor Hugo was indeed the greatest fictional artist that ever lived. But inaccuracy of statement is a peculiarly French characteristic, as most dabblers in science know very well. However, I do not wish to be ungrateful, and I will at once admit that, utterly unreliable as Victor Hugo is in any matter of fact, the fascination of his work is its own ample justification.

The hall-mark of all the Cephalopoda, or headtooted ones,' is hideousness, and their chief characteristics, voracity and omnivorousness. To begin with 


\section{28 The Cuttle-fish or Squid}

the Octopoda, or eight-footed ones, is to introduce at once to the friendly reader's notice a mollusc he is probably well-acquainted with by sight in some aquarium, one that he has often shuddered over. In truth, even when very small, there is something ghastly about the appearance of an Octopus. The sombre brown of its body, the pustular skin, the eyes in which a whole inferno of hatred of everything living seems to be concentrated, the palpitating orifice at the top of the head which is the entrance to its body, opening now and then sufficiently to show the parrot-like beak common to all the race, these are grisly features, but the eight arms, writhing, curling, clinging like a Medusa's hair, are the features of the Octopus which hold the imagination captive.

My first experience of the Octopus was in a little bay in Stewart Island, New Zealand. A small river flowed into this bay, notable for its fine flounders, and we (the crew of the ship in which I was then a sailor) soon discovered an easy way of catching these succulent fish. It was to wade about on the fine sandy bed with bare feet, the water being only up to midthigh, and when you felt the flat body wriggling under your soles, tread firmly and stoop, groping in the sand until you had your flounder safe between finger and thumb, when you could raise him and put him in the bag strapped across your shoulders.

By-and-by we discovered that the nearer the sea the finer the flounders, and so one sunny afternoon I was wading in the bay near the rivulet's mouth and picking up some fine specimens. Suddenly, I trod upon something like a blob of jelly. Fearing a sting, for most jelly-fish (Medusae) sting like nettles, I made to step off, only to feel both my legs gripped in several places by something that clung as if it would eat into 


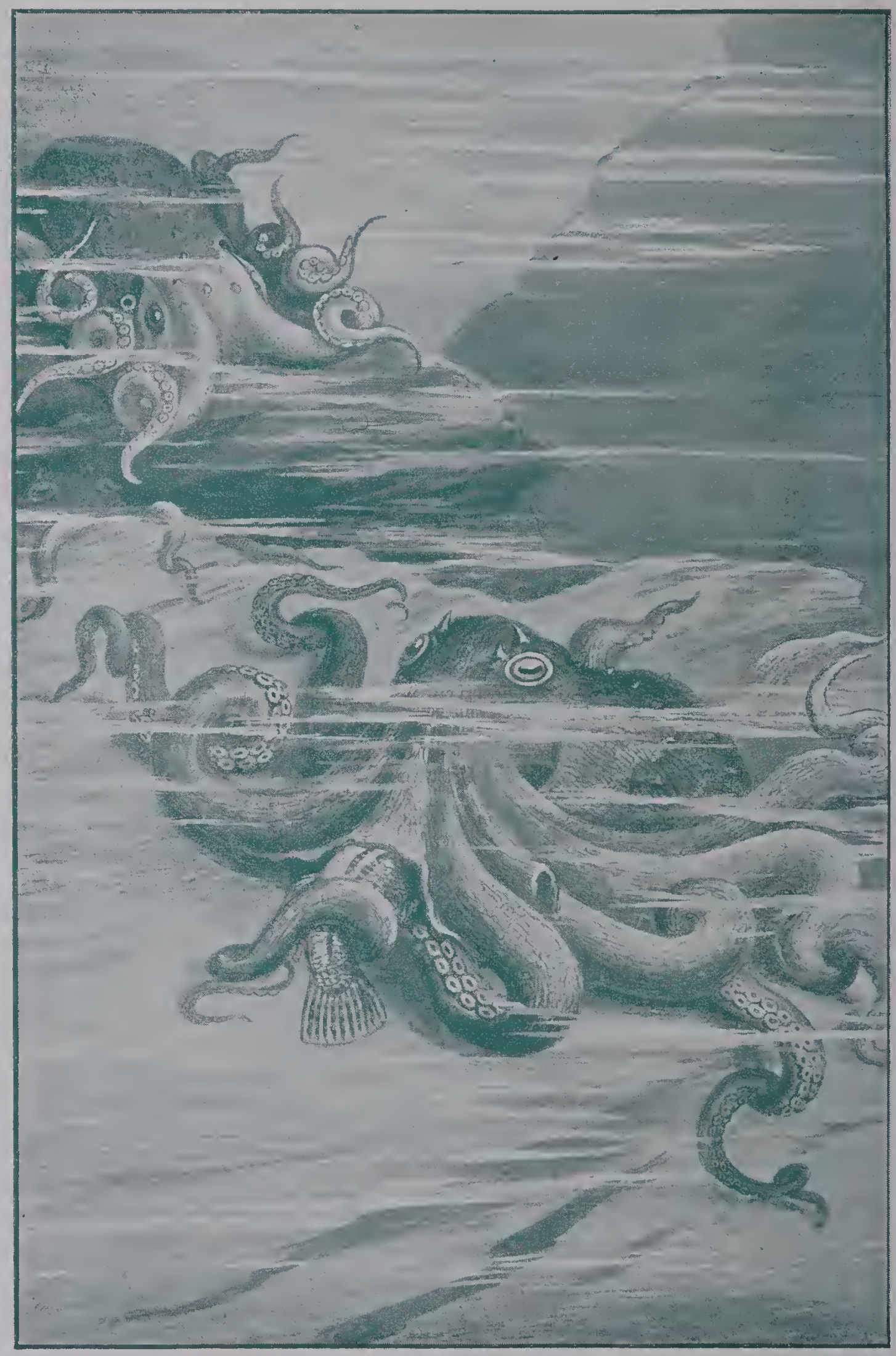

A DEEP SEA BEAST OF PREY (GIANT CUTTLE-FISH).

[To face p. I29. 


\section{The Horrible Octopus}

the flesh. I stooped and felt a long whip-like tentacle twisted round my right leg. I tore it off, a feeling of nausea making me quite giddy. But no sooner had I removed one snaky thing than another held me, and another and another. It is true the water was shallow, only reaching to my hips, but I began to feel as if I must be dragged under, drowned, and devoured by this horrible thing, whatever it was.

Fortunately I retained some presence of mind, and drawing my sheath-knife, I reached down cautiously to where I felt the main body of the thing, and avoiding my bare feet I stabbed steadily into the central part of the beast, the body, as I supposed. And I was quite successful, for presently I felt the clutch of the tentacles round my legs relax, I saw the water all distained with something which I then thought was blood, but now know as sepia, and I smelt the strong odour of stale musk, which all cuttle-fish have if you meddle with them. Also I felt strangely sick and ill. All a-tremble, at which I felt much ashamed, and more so when, on forcing myself to pick up the body of the thing, I saw that it was quite insignificant in size. Its body proper was not much larger than my two fists, while its eight tentacles were about twenty inches in length. But the whole creature looked so diabolical, an appearance which its colour, a light brown splashed with reddish spots, materially helped. And I felt quite certain, too, that, had I been laid hold of in water out of my depth by one of these creatures, only a miracle could have saved me from drowning.

Fortunately it is not the practice of the Octopus to swim about in mid-water, but only to crawl clammily about the bottom, dragging itself along by its quivering clutching arms, which stick to everything they touch 


\section{I30 The Cuttle-fish or Squid}

with a grip that only the tearing off of the sucker will release in many cases. Like the sharks, the Octopoda are true scavengers, eating anything eatable which comes in their way, but unlike the sharks they also manage to get a good deal of living food, quite large fish being often found in their clutches undergoing process of demolition. In common with all the mollusca, and more or less with fish generally, their digestive powers are amazing, the food, a fish for instance a foot long, being digested almost as it descends into the maw. They are nearly all stomach and tentacles, the other organs being insignificant. But again, like all their near and distant relatives, they pay a heavy penalty for their inability to grow a backbone, and incidentally for their succulence consequent upon their appetite. No food is so much loved by all fish of whatever kind in the sea as the flesh of the Cephalopoda. Having no bones, and in most cases no external armour to protect it, it falls a ready prey to fish large enough to withstand the pressure of its clutching arms and the onslaught of its tearing beak. And although, like fish, it is oviparous and extremely prolific, it does not increase in numbers to any extent, from the fondness of other fish for the immature Octopod; and it has, like fish, no idea of maternal care.

Now I would gladly, if I could, say a good word for the Octopus on my root-principle of justice for all. But I admit that it is very difficult. I do not see, cannot see, why the Octopus is, except for the purpose of providing abundant succulent food for shapely fish prowling along the shallow sea-bed. But that remark only goes to show the depth of my ignorance, common to all of us who study the fauna of the sea, of the real conditions of their lives. One 


\section{The Octopus of Fiction I3I}

thing, however, I do know, and that is that the many sensational pieces of fiction which have been built up Jules Verne and Victor Hugo fashion, are not worth wasting thought over.

For first of all the Octopus does not grow to any great size as far as we know, and certainly from the fact of its habitat being invariably shallow waters, we are in a far better position to know the facts as to its limitations of growth than of any other Cephalopod. Its limit of size, as far as at present ascertained, is body about the size of a football, tentacles four feet in length. Quite big enough to drown two or there men at once, if only it got the opportunity, but how far removed from the fearsome monsters of the French novelists. To sum up, the Octopus is like the rest of his appalling family, a fellow of whom no one can conscientiously say much that is good; but as with the alligator, the mosquito, and the louse, since the Lord has seen fit to create him and place him in his present position, it does not become short-sighted man to question that Supreme Wisdom.

Yet there is one point in the economy of the Octopus which we may well admire, the wonderful arrangement of sucking discs or acetabulae upon the inside of each of his arms. Their number runs into hundreds, and each of them is a perfect miniature receiver of an air-pump, acting automatically. In one experiment I made, I found that a sucker less than half an inch across lifted a tin dish weighing over a pound, and held it suspended in the air for several minutes. At this time the Octopus had been some time out of water, and was not far from death, so that his power of suction by means of his acetabulae was very much diminished. Finally, it may be laid down as a fact that the Octopoda do exhibit an intelligence and a ferocity in attack upon 


\section{I32 The Cuttle-fish or Squid}

what they regard as a prey or an enemy, that is quite disconcerting to observe in an invertebrate. But, after all, what do we know of the intelligence of the invertebrata?

The Octopoda, however, form but one small branch of the amazing family of the naked Cephalopods, whose home is in the deep sea, and whose breedingplace is no one knows where. Their divisions are as numerous as the range in their size is wide, and that is from the tiny Loligo of a couple of inches in length, to the gigantic Cuttle-fish, whose limit of size is unknown, but of which specimens have been seen as big as an adult sperm whale. Now these Decapods, or ten-armed ones, are, though of the same family as the Octopods, of widely different habits, and are also widely divergent in shape. For instance, the Octopus has a body very nearly globular in form, without a suggestion of taper to it, while all the Decapods have a cylindrical body, at the apex of which, or that part remote from the head (which yet we can hardly call a tail), is a sort of vane like that on a ship's patent log just above the propeller.

This vane has a definite purpose, now to be explained. It is obvious that no creature shaped like the Cephalopoda, i.e., with a crown of long arms branching out from the top of its head, can ever progress with any rapidity frontways, because the arms would all spread out fan-wise, and prevent such a manœuvre. But the Squid or Decapod has that matter arranged for. Its head wobbles loosely in a wide collar of gristle, in one side of which there is an orifice from which the creature can eject a jet of water. When, therefore, it is necessary for a Cuttle-fish to hasten away from the spot where it is, this hydraulic iet is put in motion, and the ejected water comes out 


\section{The Use of Squid}

with such force as to hurl the creature backward with great speed, its ten arms trailing along in a compact pointed bundle. Also that jet is stained with sepia, so that the enemies following hard after may not be able to see whither the chased has gone. Of course this method of progression varies in its speed according to the size of the creature, the smallest Squid being able to leap out of water on to a ship's deck, where every sailor has found them at some time or aniother in low latitudes. The largest ones, that is, those upon whom the sperm whale browses, cannot, I should say, move very fast ; but then all their movements are shrouded in the deepest mystery.

The range of the Decapods is enormous. They are found in some of their varieties in all the seas of all His world, and there is no doubt that they form the greater part of the food of all the higher vertebrate fish. In certain seas it is hardly too much to say the water is thick with the smaller kinds, and this is of course the case where there are shoals of fish, such as cod, to be fed. For this is the use of the Squid. There are few civilised people who care to eat Squid, although they are really not bad-tasting, but there are no fish that do not love this sapid mollusc, who has no protection whatever against their sharp teeth, no speed to speak of, and no bones to hinder digestion.

In dealing with the numbers of the sea-folk, one does not dare to compute, one can only deal in vague generalities, but I well remember once catching a fish we sailors know as a skip-jack, a kind of mackerel smaller than a bonito, and averaging four pounds in weight. There were many thousands around the ship, all busily leaping after Squid. I baited my hook with a piece of white rag and flicked it about from the jib-boom until I hooked my fish. Taking him in, I 


\section{I34 The Cuttle-fish or Squid}

opened him and found within him twenty-four Squid, packed as tightly within his maw as if they had been forced down, yet he was ready for just another one, or he would not have taken my bait. What countless myriads of these small cuttles must be bred then, to supply the needs of the millions of hungry fish like my skip-jack!

On what are all these molluscs fed? Here we must leave them, for it is quite impossible to go lower than them with any degree of certainty. That they are all fed, are all fat and well-liking, is absolutely certain, but the character of the individuals upon which they feed is just beyond our ken, as is the answer to the question of how do they enjoy their lives, being only apparently born to be chased and devoured. Yet that last is presented by so many other members of the animal kingdom that it almost ceases to excite our wonder. It must be, we feel, that the absence of prevision, of the power of anticipation, except instinctively, is the compensating factor in all such cases, preventing these myriads from dreading death, and making them enjoy present life to the full. Moreover, lingering death, the slow agony of coming dissolution, which humanity is so liable to, is almost unknown among these lower intelligences. As a rule, their transmutation, via the stomach of some higher organism, into another form of being is swift and painless, so much so, indeed, as to be almost unnoticeable.

Ascending the scale of the deep-sea Cephalopoda, we now come to a very different state of affairs. Not only are the individuals larger, but they are better armed, of higher intelligence, and fairly well able to hold their own against fish very much their superiors in size. In consequence, they are not nearly so prolific, 


\section{Insatiable Nightmares}

although their numbers must be enormous. Some of them (I do not quote the appalling nomenclature given them by scientific naturalists) are amazingly hideous in colour, in outline and disposition of armour over their gelatinous bodies. So well are they protected that it is exceedingly doubtful whether any animal smaller or less well armed than the cachalot can ever successfully interfere with them, while it is very certain that, in addition to preying upon all or any of their own kind inferior to them in size, they are terrible enemies to the large fish who chance to stray within the gloomy circle where they lie in wait, surrounded by sepia-coloured water diffused from the natural reservoir of that murky fluid.

In order that they may more fully and freely carry out their nefarious designs, they possess eyes larger and more powerful in proportion to their size than does any other creature, not excepting insects with their thousand-faceted eyes. These great optical mirrors, black as an inkpool and lidless, not even a nictitating membrane shielding their all-embracing glare, are set one on each side of the cylindrical head, on which they occupy so much space that their side edges nearly touch. And as the head itself is borne upon a column of soft, gristly, boneless substance so that it can turn every way, with a universal ball-and socket-joint movement, it must be impossible for any object to escape that devouring purview.

The adjuncts to the eyes are the restless tentacles, a living, palpitating network, never still, always quivering like the petals of a sea anemone, which most people have watched in an aquarium. Then these Cephalopoda have an additional weapon granted them in that each one of the curious acetabulae, sucking discs or air-pump receivers, whatever we like to call them. 


\section{I36 The Cuttle-fish or Squid}

which line the inside of each of the eight tentacula and the ends of the two long ones, has a row of claws like those of a tiger's set round its inner edge. And when a victim touches one of those tentacles the suckers cling and automatically the claws begin to tear, so that a speedy journey down the gulf in the centre of the group of arms must come as a sweet relief from the sensation of being devoured by many mouths at once.

In the matter of food they are, like most of the deep-sea folk, without any vulgar prejudices. Whatever they get that is eatable is the thing they want, nor do they waste time and trouble in selection. Presumably, though the study of these curious creatures bristles with difficulty, different species inhabit different depths, but nearly all the larger kinds prefer deep waters, say one hundred fathoms or so, while the small ones like the Octopoda keep near the surface.

Coming to the largest of all, the gigantic Cuttlefish, several very curious facts present themselves at once. The first is that as far back as the day of Aristotle, Pliny, and Elian, the gigantic Cuttle-fish was fairly well known and described. Pliny, indeed, tells a story which, knowing what we know of the habits of the Cuttle-fish as distinct from the Octopoda, savours of the incredible. While he was consul in Spain, he says, one of these monsters acquired the bad habit of coming ashore by night and plundering the salt-fish warehouses. It came once too often, and was slain. Being brought under Pliny's notice he conceived a joke. He caused the head to be cut off, and a cask of fifteen amphorae capacity was filled with it (somewhat larger than a sugar hogshead, we must suppose). This he sent to his friend Lucullus in Sicily to grace one of his memorable banquets, adding that he knew his love for fish. He also adds 


\section{Cuttle-fish Yarns}

a few details, such as that the arms were thirty feet long, and so thick that a man's arms could hardly meet round them at their bases, these arms being provided with acetabulae large as basins holding four or five gallons. Now, with the sole exception of the burglarious habit of this Cuttle-fish, which if true has certainly been discontinued by the creature's descendants, these details are not very wide of possible and probable truth, and indeed, well within the truth as regards size of many that have been seen and described of late years.

But coming down to mediæval times, such writers as Paulinus (who thinks that the great Cuttle must be a vast crab), Bartholinus, Athanasius Kircher, Olaus Magnus, and Pontoppidan, Bishop of Bergen, we find quite a different style of writing, and a steep descent into utter inaccuracy. Not being gifted with either the literary ability or the judicial restraint of the pagan writers, these Northern littérateurs launched into the wildest fables, and supplemented their literary fancies by such outrageous caricatures that ordinary minds very justly recoiled from them, feeling that they could not be true. For instance, Pontoppidan, though a bishop, was the author of a monstrous tale built up from the simple story of some fishermen, who undoubtedly did come across the body of a vast Cephalopod in the North Sea, and related their experiences to him. No doubt they exaggerated, that was only natural in them, but Pontoppidan's story is wild as the Avatar of the Fish from the Mahabharata.

Very briefly his version was this : that a fleet of ships while at sea sighted an island where no island should be, and determining to explore this strange land, anchored their vessels and landed. When suddenly, to their horror, there arose around the island 


\section{I38 The Cuttle-fish or Squid}

a multitude of serpent-like arms taller than the masts of the vessels, which embraced the ships and collected the crews until. with a horrible whirling of the whole ocean, island and ships and men disappeared for ever. And he does not even explain to us whence he derived his information.

This creature is undoubtedly the Kraken of old Norse legends, sufficiently awe-inspiring in its supreme hideousness and its vast size to excuse the wildest tale told by a shuddering eye-witness of its prowess in those far-off days; yes, even sufficiently terrible to account for its being considered the originating cause of the mäelstrom off the Lofoden Islands, around which so many hair-raising tales have clustered.

But what does seem incomprehensible to me is that, after so many indisputable glimpses of the great Cuttle-fish during those early years, the exaggerations of the historians should have been able to cause such a revulsion of feeling as to make people disbelieve in the existence of such a creature at all. Yet that is exactly what happened, in spite of the fact that very many authentic records exist of appearances of the creature. It is true that at the same time many fables were current anent the appearance of the great seaserpent, most of which were doubtless due to hurried glimpses of the gigantic Cuttle-fish in his conflict with a sperm whale. But why stories of the mythical sea-serpent should have been accepted, and accounts of the real mollusc have been rejected, it is impossible to say. It must, I suppose, remain a mystery.

An added wonder comes from the fact that the American sperm whale fishery has existed for well over a century, and during the whole of that time every officer, to say nothing of the men, must have known of the very real existence of the great Squid, since scarcely 


\section{Squid Superstitions}

a sperm whale can be killed without first ejecting from his stomach huge fragments of this popularly believed by seamen to be the largest of all God's creatures. Not only so, but in every book which has been written about the sperm whale fishery some allusion to the great Cuttle-fish will surely be found, although it must be admitted that so much superstitiously childish matter is usually mixed up with the facts as to make the latter difficult of belief. For instance, Herman Melville's wonderful Moby Dick, or the White Whale, which is, and must remain, the classic upon this subject, both from the magic of its style and the accuracy of its descriptions, has the following :-

-Almost forgetting for the moment all thoughts of Moby Dick, we now gazed at the most wondrous phenomenon which the secret seas have hitherto revealed to mankind. A vast pulpy mass, furlongs (?) in length and breadth, of a glancing cream colour, lay floating on the water, innumerable long arms radiating from its centre, and curling and twisting like a nest of anacondas, as if blindly to clutch at any object within reach. No perceptible face or front did it have; no conceivable token of either sensation or instinct, but undulated there on the billows an unearthly, formless, chance-like apparition of life. As with a low sucking sound it slowly disappeared again, Starbuck, still gazing at the agitated waters where it had sunk, with a wild voice, exclaimed : "Almost rather had I seen Moby Dick and fought him, than to have seen thee, thou white ghost.".

" "What was it, sir?" said Flask.

" "The great live Squid, which, they say, few whaleships ever beheld and returned to their ports to tell of it." " 


\section{I40 The Cuttle-fish or Squid}

Now this excerpt is typical of the way in which appearances of the Squid were treated, and may possibly account for the scepticism, in an age growing with enlightenment, with which such stories were received. But why, in the name of patience and common-sense, visions of fragments of the animal should be regarded as usual and natural, while to view the entire beast portended the most awful calamities, passes the wit of man to understand. Certain it is that many of the old whale-men believed the Squid upon which the sperm whale feeds to be one unthinkably vast animal sprawling upon the sea-bed, and renewing with amazing facility and kindliness such portions of his anatomy as the hungry whales were continually biting off. But probably this is more than enough of such fantastic fables.

The plain facts about the gigantic Squid which are well authenticated are few but substantial. First, his habitat is certainly within the limit of five hundred fathom' depth and in places where there is much food suitable for him, that is, fish of goodly size and smaller members of his own species. And it would seem that having found such a spot he is not willing to leave it, being, although amazingly strong, of a sluggish, lethargic habit. He does not pursue his prey; he waits like some unimaginable spider in the centre of his web of far reaching tentacles, with his huge eyes piercing the surrounding sepia-stained waters until a quiver from one of the outlying arms sets the abysmal mouth agape, the mighty parrot-like mandibles clashing as the struggling victim is conveyed inwards. He has no care, no difficulty of providing food. All he needs comes to him, and what an all that must be! I have myself seen a creature of this specles in the act of being 


\section{Squid Mysteries}

devoured by a sperm whale, whose length could not have been much less than sixty feet, exclusive of the tentacles, and whose girth would be about fifteen or twenty feet. The devouring capacity of such a creature must be of fabulous dimensions, since, as before noted, while all the sea-folk have amazing digestive powers, the Cephalopoda are pre-eminent in this direction. Their bodies may roughly be described as bags of digestive juices which dissolve the food as it comes in, and like the parabolic daughters of the horse-leech, the cephalopod's stomach, that is to say, almost his whole body, is ever crying 'Give, give,' and never says 'Hold, enongh.'

Since even this vast mollusc's very existence has been strenuously denied up till quite recent years by scientific naturalists, it follows that we have but few details concerning him. Some things, however, we may know by inference, and amongst them are the following. The gigantic Cuttle-fish must be very prolific. He is the principal food, the main support of the sperm whale, and as this vast mammal's numbers are incalculable, and each individual needs, at the very lowest computation, a ton of food per day to keep him going, the numbers of the mollusca upon which he feeds must be proportionate. As to the numbers of the sperm whale I may say, in passing, that it has several times been my lot to witness an assemblage of cachalots, all of the largest size, covering an area of ocean as far as the eye could reach from the masthead of our ship in every direction. That is to say, we were the centre of a circle of vision thirty miles in diameter, and wherever the eye rested in that circle it saw sperm whales spouting. Only to think of the amount of food required for that stupendous host makes the mind reel. 


\section{I42 The Cuttle-fish or Squid}

Next, he must grow very rapidly. As I have before stated, I think, it is the almost invariable habit of the sperm whale to eject the contents of his stomach just before death. All that I have seen die did so with one exception, and that one died so suddenly that he did not even go into the usual 'flurry,' or death agony. And all the fragments ejected were of enormous size, showing conclusively that they had been bitten from monstrous Squid. What is more remarkable is that I never saw entire ones vomited up, although I cannot but believe that they, the cachalots, must swallow a great many of medium size, say from six to ten feet long or so, entire. I did once see a fairly comprehensive collection of Cuttles and vertebrate fish in the stomach of a stranded whale, and I see no reason to suppose that there was anything singular about him; but with regard to the ejecta from the whale's stomach while dying, in my whole experience it is as I say, they were fragments of mollusca of the most heroic size.

Another fact, and that one of the most curious connected with this strange creature, is the scent of musk which he exhales. Most of us know that sepia, the artist's sepia, bought in tubes or cakes, is musky to the smell, but few connect it with the natural odour of the Cuttle-fish. It shares this odour with the alligator, musk-rat, and musk-deer, wherein is concealed another mystery of Nature. But it must be admitted, I think, although I do not know what perfumers would say on the point, that none of the musk obtainable from these animal sources has the sweetly delicate scent of the Mimulus moschatus, or garden musk, which makes our gardens so fragrant after a shower of rain. Such as it is, however, the scent of the Cuttle-fish undoubtedly gives its valuable 


\section{Musk and Marriage}

quality to that strange substance, ambergris, which is secreted by the sperm whale alone. It always smells faintly of musk and always has Cuttle-fish beaks imbedded in its substance. But its properties, apart from those fantastic attributes which Arabian superstition has attached to it, are not those of a perfume, but of a power that accentuates, heightens the quality and pungency of any distillation of perfume to which it is added. Surely a strange product of such a weird monster brooding in the depths of the sea.

These few facts almost exhaust what we know of the gigantic Cuttle-fish. It is credited with other qualities, which we need not place too much faith in, namely, that it can introduce one of its tentacles into its stomach and withdraw from thence any substance which is causing it uneasiness; that it can, if bereft of a limb, set to work at once and reproduce the lost member; and that when food runs short below it can come to the surface, and finding a becalmed ship, lay her aboard and collect from her cabin, forecastle, and rigging, every member of the crew. Strange enough in all conscience, but no stranger, surely, than the fact I reserve for the last. The gigantic Cuttlefish has no mate, at least none that he ever knows. But at certain seasons he grows an additional tentacle, a curious, dwarfed, club-headed thing, which looks strangely out of place among the ten ordinary ones. In due time this extra tentacle matures. It then detaches itself from the crown of its source and floats away. In due time it finds the predestined spouse, to which it immediately attaches itself. And in this extraordinary fashion is the gigantic Cuttle-fish reproduced - surely the strangest in all natural history and only comparable to the grafting of fruit-trees. But the 


\section{I44 The Cuttle-fish or Squid}

latter is not nearly so wonderful, seeing that it is most carefully carried out by the hand of man and with all the resources of his intelligence.

With this I complete these all-too-brief sketches of the sea mammals, Sharks and Cuttles. All of these creatures are so sufficiently interesting, and have so many anecdotes clustering around them, that they might well claim a book to themselves. But, in pursuance of the original idea of these sketches I have sternly resisted the temptation to 'pad' them out, feeling sure that the scantier the information given. consistent with interest, the better will it be retained. We now come to the fish of the deep sea. I do not suggest that the shark, already dealt with, is not a fish, but he is a fish in a distinct category by himself. I have noted most of his peculiarities, and feel sure that my readers will agree with me when I say that he must be kept apart from what most of us understand as fish. Wholesome fish with scales and fins, that is; fish that we can all recognise as such, whether they swim the deep sea or frequent the rivers and ponds.

Not, be it undertsood, that I would cast any reflection upon a fish because he was not beautiful, as say a mackerel or a red mullet. That would be unfair, especially as I remember a fish I was once acquainted with in Hobson's Bay, called locally the 'flat-head.' It was simply hideous, and its colour that of dark mud. Moreover, the only way to get it off a hook without the certainty of getting a poisoned wound, that would certainly incapacitate one for a week or two, was to fling it down and stick a knife through the base of its head, and so, holding it impaled, to extract the hook. Yet as food it was in every way superb. white and sapid in flesh, and in flavour de- 


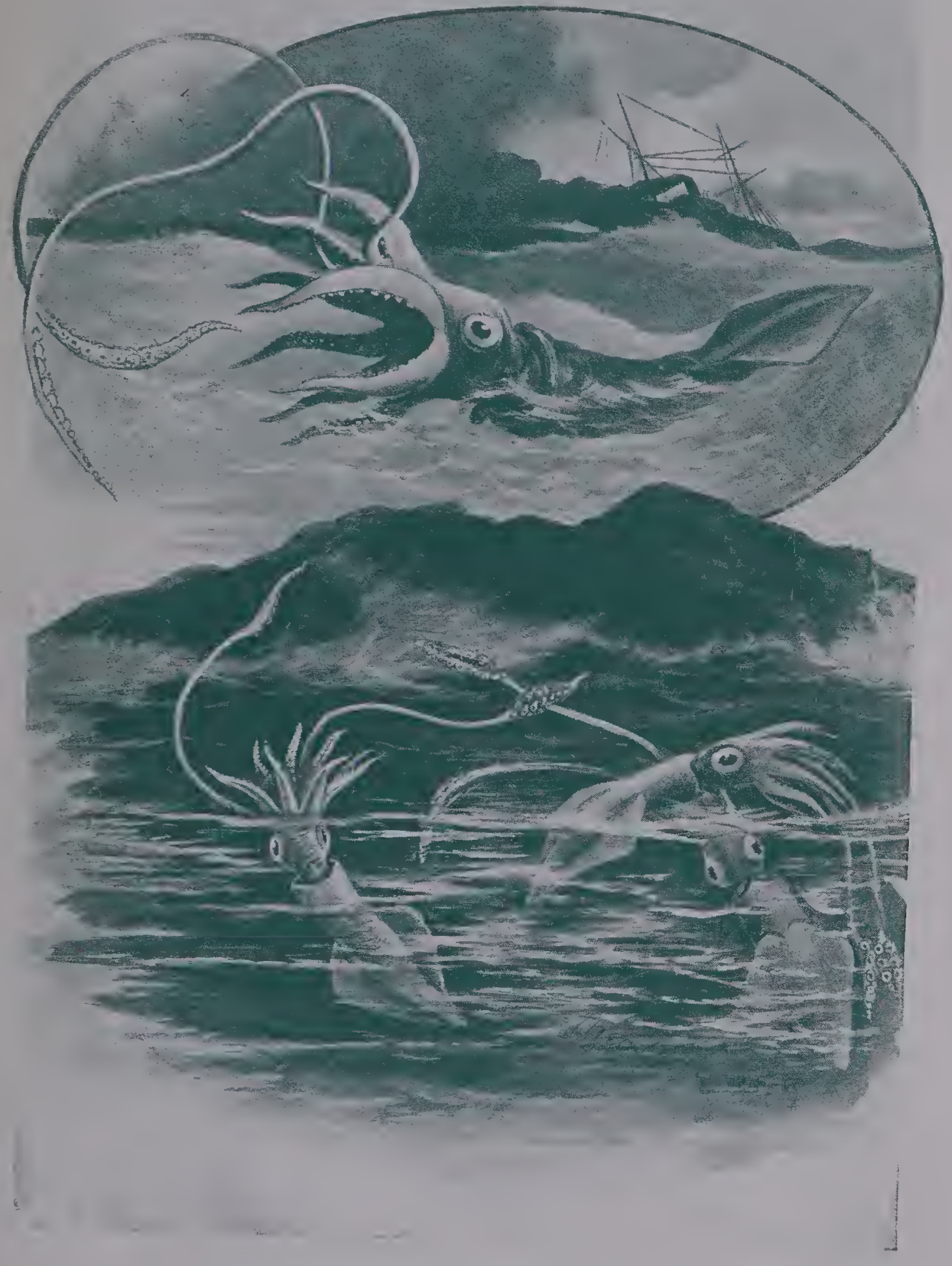

GIANT SOLID AND COMMON LOLIGO.

[To face p. I 44 . 



\section{Beauty versus Utility I45}

licious. Some of the most brilliantly beautiful fish I have ever known have been the most dangerous to man because of their poisonous qualities. And conversely, some of the most ungainly, dull, and quaintlooking fish, such as all the flat fish undoubtedly are, are the most useful, the most valuable. With fish as with us, beauty is but skin deep, and is but little index to the deeper and more lasting qualities. 


\section{CHAPTER XIII}

\section{DEEP-SEA CHIMÆRAS}

I $\mathrm{N}$ this chapter it becomes necessary for me to depart almost entirely from my usual practice of drawing upon personal experience, for very obvious reasons. The extraordinary creatures of which I am about to write I have called chimæras, since their aspect is quite outré and startling, even horrible, enough to justify the epithet fully. And, fortunately for the peace of mind of sailors, the latter very rarely come in contact with them. They have their abode in varying depths of the dim and silent sea, and only of comparatively late years has any study of them been possible.

The epoch-making voyage of the 'Challenger' furnished much of the material for Dr. Günther's magnificent work on deep-sea fishes, and since that time other nations, notably and principally the Americans, have been carrying on the same deeply interesting work. One striking result of oceanic investigation has been the establishing as a certainty that fish, highly developed and normally organised fish, can and do exist at great depths, but what those depths are cannot in the nature of things be determined with any accuracy. For the net in which these fish are caught is open all the time both descending and ascending, and consequently fish which are well known to be surface dwellers have been drawn up, much distorted, from a depth of two thousand fathoms or more. 


\section{Deep-Sea Mystery}

Also it follows from the method necessarily employed in their capture that great and extraordinary as are the varieties of deep-sea fish now known, there must be a very great number more who, by reason of their agility or their size, have never been, and can hardly be expected to be, caught. Still, of shell-fish or slow-moving species of shell-less fish a goodly harvest has been gathered from all depths, even to the greatest, so that it is now known that in the most profound abysses of ocean, such as that vast chasm in the South Pacific on the north and east of New Zealand, where a measured depth of nearly thirty-one thousand feet has been plumbed, there is abundant life at the bottom, although it is, as far as is k own, of a low order.

In these days of amazing strides in science it is extremely risky to prophesy of anything that it can never be fully investigated, but if there be one thing of which it seems safe to predict that our knowledge has almost reached its limit, it is that of life at great seadepths. For one thing, and that an exceedingly important one, such investigation can promise no great commercial or even scientific gain. Its pursuit can at the best be only rewarded by the acquisition of much curious, out-of-the-way knowledge of a side of life at present involved in deepest mystery. But just because it is so mysterious, because the conditions of living at those vast depths, under those amazing, almost unthinkable pressures, is almost as difficult for our senseperceptions to apprehend as those of life in Jupiter or Saturn or the Sun, so ardent seekers after new truth will undoubtedly be irresistibly attracted by what I should like to call Oceanology, the term Oceanic Ichthyology being to my mind far too cumbrous for ordinary use.

It has several times been my privilege (not at all 


\section{I48 Deep-Sea Chimæras}

appreciated at the time) to see some very queer fish upon the sea-surface in remote parts of the ocean during long complete calms. At such times the apparent stagnation of the sea (I say apparent, because it is impossible for the sea ever to be really stagnant) has the strange effect of inducing the denizens of the lower strata to come to the surface, although how they accommodate themselves to the great changes of pressure they must experience is a matter quite beyond my comprehension. The more so as, when I have been fishing at a depth of from four to six hundred feet, my victims have invariably come to the surface with everted viscera, due, without doubt, to the sudden change of pressure upon them.

But these extraordinary visitors to an upper sphere, where they stared glassily at the unfamiliar sunlight, and moved sluggishly and aimlessly about as if bewildered, were in no way hampered apparently by the loss of any important internal furniture. They were never large, and many of them were of a very low order of animal, notably one, the only part of which that looked complete being its head; the body, about four feet long, ribbon-like and about four inches wide, being perfectly transparent, almost impalpably so. Through that phantom-like covering one could see every detail of the slender vertebræ, watch all the alimentary processes; indeed, it was as if by some curious process of radiography the flesh had disappeared, leaving only the scanty internal details visible. Yet the head, as I have hinted, was solid enough, and perfect in every detail, having two brilliant eyes and a well-furnished mouth of teeth.

Another strange beast that I managed to capture in a draw-bucket, so sluggish was he, has ever been present since to my mental vision. Many queer fish 


\section{A Freak Fish}

have I seen since then, both in reality and in their counterfeit presentments, but none with such a wealth of quaint decoration as this. He was about eighteen inches long, with an angular head like a gurnard, and a body shaped like a haddock. So that in his general contour there was nothing particularly strange. But his colour was bright green, at least that was the ground, so to speak, of his scheme of decoration. Scattered about his body were brilliant crimson spots, mostly circular and about half-an-inch in diameter. From each of these spots there sprouted a tassel of bright blue upon a yellow stalk about one inch in length. All his fins were also extensively fringed with blue filaments, which kept up a perpetual fluttering, however still the body might be. His tail was, for his body, enormous, being quite as wide as his body was long and also fringed profusely with blue. His eyes had no speculation in them or decided colour ; in fact they had the appearance of being boiled. And over each of them protruded a yellow horn about three inches long, with a pendant tassel of blue on the end of it, which dangled down at the angle of a conspicuously large mouth. And on the back of the creature rose a brilliant crimson dorsal fin running the whole length of the animal, about two inches high, and terminating in a long spike running forward over his nose. This also had a blue tassel, larger than any of the others, dangling from it. The whole made up a tout ensemble that I think warrants me in giving so full a description of him.

Yet in spite of the extraordinary development, both in shape and colour, the fish as a fish was not queer. Prepared for cooking he would have excited no comment. But that cannot be said of the extraordinary creatures captured and described by the members of the various expeditions that have been exploring 


\section{I50 Deep-Sea Chimæras}

the deep sea during this last quarter of a century. The salient note of these chimæras strikes me as being paradox. You shall find one fish of normal shape with enormous eyes, which will strike one as being indicated as necessary at those dim depths. But the next one, apparently of the same species as far as outline goes and depth of habitat, has but the rudiments of eyes, mere pin-points of black on each side of the head. Again, two fish are brought up from apparently the same depths. One has an enormous body, with corresponding stomach, and a mouth which will barely admit the little finger ; the other has a body like a whip-thong, or, say, a small eel, tapering to a vanishing point, and a mouth like a pelican's exactly. One fish will have a stomach large enough to contain a fish as big as himself (the stomach expanding, of course) in the usual situation for that organ; another has a maw equally large, but it is on the back! for all the world like the hump of a deformed camel. Other fish have immense tail fins, while close relatives have absolutely none, their bodies tapering off to nothing, without the vestige of a fin.

Now I am fully aware that all this sounds like the rioting of a luxuriant imagination, but the illustrations are taken from life, and I do not think they will lead any one to believe that I have exaggerated at all. And it should also be remembered that those specimens that we have, picked up as they have been in widely separated areas of ocean and at various times, are not likely to be even representative of the strange sub-oceanic life. They only afford a glimpse, as it were, into this secret realm of Nature where she has outdone herself in the fashioning of strange monsters. One other remark must be made before procecding to particularise some individuals; it is concerning light. 


\section{Self Illuminators I5I}

Most of us know well how in the marvellous economy of Nature the sea is illuminated, and that brilliantly too, by the presence of myriads of infusoria emitting phosphorescence. The slightest agitation in the sea causes these marine glow-worms or fire-flies to shed all the light they are capable of, and thus the passage of one fish is made exceedingly obvious to another, who may be pursuing him or desirous of avoiding him. But this illumination varies in degree from differing causes, and sometimes the sea is almost totally devoid of any light. It may be, too, that as this natural light is affected in degree by certain causes operating near the surface or horizontally, so it is affected by vertical position. We do not know. What we do know is that many deep-sea fish have, as it were, their own electric light installation, row upon row or group after group of tiny incandescent lamps, glowing and fading at the will of their owner, rendering him invisible at will or lighting up the surrounding sea so that none of his intended victims may be hidden. These tiny glow-lamps are arranged along the sides and head of the fish in strangely regular rows or groups, each differing species that possess this system of self-illumination having them different.

One thing more. In dealing with these fearsome denizens of the vasty deep I must perforce use the no-less appalling nomenclature given them by naturalists, since other names they have none. For this I hope, under the circumstances, I shall be forgiven.

It is a commonplace with naturalists in dealing with deep-sea fish that several of their most interesting species have come fortuitously to hand. No amount of care or scientific appliances could have secured them, and but for the accident of their coming to the 


\section{I52 Deep-Sea Chimæras}

surface occasionally under the stress of some compulsory circumstance of which we know nothing, we should never have known of their existence. Of such is the Regalecus or Oar-fish, so called from the fact that it has the two ventral fins, which spring from the throat, if you please, just beneath the pectorals, enormously elongated, slender and with paddle-shaped terminals, as if, indeed, it had developed two oars to assist its progress through the water. But its chief claim to our notice lies in the fact that it has undoubtedly furnished forth the materials for many a seaserpent story, as will be seen in the chapter on seaserpents.

It has been found stranded in many places round the world, in places as widely separated as England, India, and New Zealand. Dr. Günther records nearly fifty instances of its being found and carefully examined, so that its existence admits of no doubt. It has been found twenty feet in length, by about eighteen inches in depth, but very narrow in proportion. And it is more than probable that it grows very much longer than this in its mysterious haunts in the deep sea. It has a large dorsal fin extending the whole length of its body, developing at the front end into nine spines, from twelve to eighteen inches in length, which branch out diagonally forward over the creature's nose, but curve backward towards the tips. Its head is insignificant compared with its body, and its curiously small mouth, not at all uniike a sturgeon's, is destitute of teeth, showing its absolute harmlessness.

For some reason difficult to understand it has been called by fishermen the King of the Herrings. Perhaps they connect its appearance with large catches of that useful fish, but one would have thought that the title must belong of right to the tarpon, which 


\section{A Possible Sea-Serpent I53}

is a bona fide herring and sometimes scales in the vicinity of two hundred pounds.

It will, I think, be readily understood that a great serpentine fish like this, totally unlike any other fish with which the ordinary fisherman or sailor is acquainted, appearing with sinuous, stealthy gliding along the sea-surface, say in the early twilight of morning, might very easily give rise, with a little quite excusable exaggeration, to a story of a sea-serpent. It will be remembered too, that, in many sea-serpent yarns, the monster is represented as having a mane and oar-like fins. Here in Regalecus the conditions are favourable to such a description-the extraordinary dorsal development and the oar-shaped ventrals undoubtedly lending themselves to such a conclusion.

As with the rest of the deep-sea chimæras, nothing is or can be known of the habits of the Regalecus. We can only say that it has an enormous range of habitat, lives in deep water upon small organisms, and is sometimes constrained to come to the surface, when, if near shore, its feeble powers of locomotion (I have omitted to state that the tail fin is entirely absent) are not sufficient to enable it to keep off the land. In colour the Regalecus is a silvery grey, with a few darker spots near the tail. Deep-sea fishes do not run to elaborate colourings.

The next monster down for notice is a very good specimen of the deep-sea chimæra, Chiasmodon niger. It is a veritable nightmare in appearance, being entirely black in colour, with a mouth that cleaves the head asunder laterally for its whole length, so that vulgarly speaking, when its mouth is wide open it has no profile. This immense mouth is furnished with equally effective teeth, which are not only found in the jaws but on the palate also. Its front teeth are hooked and movable, 


\section{I54 Deep-Sea Chimæras}

so that while they may be pushed inward to admit of the entrance of prey, they effectually prevent it from coming out. This peculiarity is explained by a slight examination of the creature's feeding habits. It can and does swallow entire fish actually larger than itselfwhich sounds impossible, but it is not. For the belly of this atrocious glutton is like an india-rubber bladder which may be expanded amazingly. And consequently by dint of perseverance Chiasmodon can and does draw himself on to the body of another fish, as it were, until the visitor is snugly coiled away in that expanding bag, which being transparent, shows plainly from the outside the position of its occupant.

In other respects Chiasmodon is rather an elegant fish, quite normally fish-like, which one would hardly expect, considering the great depths from which it has been brought. The 'Challenger's' trawl brought up one in mid-Atlantic from a depth of one thousand five hundred fathoms, or nine thousand feet. Another specimen was brought up from a depth of three hundred and twelve fathoms, near Madeira. But several have been found floating upon the sea-surface, having succumbed to a very natural disaster considering their habit of gorging, namely, they have burst! And the tissues becoming inflated with gas have rapidly raised the dead mass from the immense depths in which it has lived to the revealing glare of day, to become the wonder and awe of us beings of the surface. This extraordinary creature is one of the best known and most fully described of all the abyssal fish, as it is certainly one of the most wonderful.

Two very peculiar little fish next demand notice from the fact that, although very similar in size, in outline, and in depth of habitat, they have in certain respects the most widely marked differences imaginable. 
They are black, chubby creatures, with enormous mouths compared with their length, which in the specimens given is from four to five inches. And they are called Rondeletia and Cetomimus. Now Rondeletia has an eye, of which the diameter is one-sixth the length of the head, or about twice as large in proportion to its size as is the human eye. Cetomimus has an eye which is but a point like a pin's head, its diameter being one twenty-third the length of the head, or less than the sixteenth of an inch. Rondeletia has no trace of a lateral line, that general characteristic of fishes, but Cetomimus has double lateral lines, the two parallels being joined here and there by bands much like the ladder tape of a venetian blind. The depths from which these strange little fish have been taken vary from one thousand to one thousand five hundred fathoms.

As an instance of the diversity obtaining between deep-sea fish, scarcely any specimens could be found more appropriate than Simenchelys and Eurypharynx, whose amazing names are really justified by the queerness of the fish. Simenchelys abides anywhere from one to five hundred fathoms down. He is black, a dirty black, as are most of the deep-dwelling fish, and has a comfortably stout body, much like that of a stalwart eel. But his mouth gives great occasion for wonder as to how he can possibly obtain food through such a tiny opening. It is the most insignificant orifice imaginable, comparable only (and proportionately) to a hole made in the end of a sausage with a flat skewer. But presently it is found that this queer fish is really a sort of gigantic leech. He attaches himself to the bodies of the larger, fleshier fish, such as the halibut, and by sheer force of suction and boring withal works his ravenous way right into 


\section{I56 Deep-Sea Chimæras}

their bodies, at what misery to his involuntary hosts can only be imagined.

It is curious and instructive to compare him with Eurypharynx, well surnamed Pelicanoides, who, with a body like the thong of a stock-whip, has a head about thrice its body's bulk, and jaws opening exactly like the mandibles of a pelican. This amazing mouth splits the big head right in two lengthways, and the eyes are situated right at the end of the upper jaw, looking indeed like tiny nostrils, for they are mere points. Yet for all its fearsome appearance this is evidently one of the most harmless of fish. It appears to live upon the tiniest marine organisms, which in some unexplainable way it collects in its chasm of a mouth from the surrounding sea. It has no teeth, a tail tapering off like the lash of a whip, and for all sign of fins a series of spines protruding from its back and belly without any membranes between them.

A deep-water fish akin to Chiasmodon, and found at a depth of nine hundred fathoms, has an even wider mouth, but no teeth in the lower jaw. Its only fins are a pair of rudimentary pectorals with the gill-slits behind them. About fourteen inches of its body is mainly stomach, through the walls of which transparent organ may be seen calmly reposing the body of a large fish which has been induced to take up its permanent abode there. But the rest of the body, four feet or so, is like a whip-lash. In the specimen before me there appears tò be one fish going ahead and another going astern, two heads on the same body, for the head of the swallowed fish seems about to emerge from the rear of the stomach and swim away. It is a very quaint beast indeed, and rejoices or suffers under the euphonious epithet of Saccopharynx flagellum.

Alepisaurus ferox is the name given to a fish that 


\section{A Swift Glutton}

at first sight is not at all unlike the gigantic mackerel called the sword-fish. Its body is certainly somewhat slenderer, and it has no sword protruding from its upper jaw, but in contour of body, arrangement of fins, and especially the huge sail-like dorsal, it is very similar. This last extraordinary member is like the upper third of a circle, cut off horizontally. In the centre it is twice as high as the body is wide, and its limits fore and aft are from the neck to a few inches forward of the tail. Its head is ferocious-looking enough to justify its Latin title, even if its fierce voracity were not known by the contents of its stomach, one having been found with twenty-seven specimens of the spiny lump-fish within its maw. It has not many teeth, but they are large and fang-like, also they point backwards into the mouth, obviously to prevent the wriggling outwards of living prey. Like several other predatory fish whose attacks are characterised by swift directness, this creature has the lower jaw longer than the upper, reminding one strongly of the pike. Altogether $A$. ferox is an elegant warlike-looking fish, whose appearance is not at all outre, even though it does frequent great depths.

Its range is very great, specimens having been found in the North-Western Atlantic, in Australian seas, and in the Northern Pacific. But this may safely be predicated of nearly all deep-sea fishes, the temperature below a thousand feet being everywhere the same, except where submarine geysers send their boiling waters up into the superincumbent ocean. And as the composition of the ocean waters is practically the same everywhere, it may be reasonably inferred that denizens of waters below the fixed temperature line will be found all the watery world over wherever the ocean is deep enough, which, indeed, has so far 


\section{I58 Deep-Sea Chimæras}

proved to be the fact wherever the number of individuals caught admits of distinction of habitat.

The chief wonder about this fish, however, is its extreme fragility. It is so brittle that handling it is almost an impossibility without breaking it. It is quite impossible to preserve an entire specimen without some portion of its fins being damaged, and should it be let fall it would shiver like glass. Dr. Günther says that 'this is a condition consequent upon their withdrawal from the pressure of the water to which they are exposed in the depths where they dwell. When within the limits of their natural haunts the osseous, muscular, and fibrous parts of the body will have that solidity which is required for the rapid and powerful movements of a predatory fish.' This is indeed a curious state of things, that a creature too fragile to endure handling at the surface can indulge in fierce, relentless warfare in those awful depths, where pressures are so great as to force water through the pores of cast steel. But there is no doubt about the fact, for some of the lightest shells known, a species of Janthina, more like a soap-bubble than anything stronger, have been dredged up from enormous depths, and, lying upon the laboratory table, an incautious breath has shattered them.

I judge from this peculiarity on the part of deep-sea fish that a curious fish, often found after the cold weather lying upon the beaches in various parts of New Zealand, must be a deep-sea fish. It is locally called a Frost-fish. It is very long, five feet or so, and narrow, only about four inches wide by two inches thick. It has a very large mouth and quite insignificant fins, tail included, but dorsal fins running the whole length of its body. Lying upon the beach in the moonlight, it looks like a riband of silver, and running 


\section{A Deep-Sea Beauty $\quad 159$}

incautiously up to one once, I found to my astonishment that as I lifted it by the middle it broke into four pieces as if it had been a bar of lightly frozen snow. It is a fish much prized by New Zealand folk for the table, but it is never caught except when it gets stranded as I have described. It is almost if not quite identical with Benthodesmus Atlanticus, found in the stomach of a halibut caught on the Grand Bank of Newfoundland, also in the West Indian Seas, South Pacific, and coast of Japan.

A fish of only quasi deep-sea habits, whose name, bestowed by naturalists, boasts of eleven syllables, Lopholatilus chamaeleonticeps, was a quarter of a century ago an object of deepest interest and discussion among that hardy and most enterprising class, the American deep-water fishermen. In 1879 it is recorded that the 'Wm. V. Hutchings,' while setting trawl-lines for cod on Nantucket shoals, caught several hundred specimens. It was entirely unlike anything ever known in American waters, and as it was large, averaging three feet long by ten inches high and four inches through, it was thought and hoped that a discovery of great commercial value had been made. And the first thing done was to give it a handy name, without regard to any fitness of application. So it was called the Tile-fish, from the fourth syllable of its hybrid Græco-Latin name Lopholatilus.

Most unusually, Dr. Goode, who describes it, goes into something very like a rapture over it, even to the length of using superlatives. In addition to the usual notes upon structure, etc., he says: 'The colours are very beautiful, and in general appearance when taken from the water it is one of the loveliest fish we have ever seen, no exception being made in favour of the brilliant parrot-fish or angel-fish of the 


\section{Deep-Sea Chimeras}

West Indian coral groves. Back bluish, with a green tinge, iridescent, changing through purplish-blue and bluish-grey to rosy-white below, and milky-white towards the median line of the belly. Head rosy, iridescent, with red tints most abundant on the forehead, blue under the eyes, cheeks fawn-coloured. Throat and under-side of the head pearly-white, with an occasional tint of lemon-yellow, this most pronounced in front of the ventrals and on the anterior portion of ventral fins. Back with numerous maculations of bright lemon or golden. Anal fin purplish, with blue and rose tints, iridescent. Margin of anal fin rich purplish-blue, iridescent like the most beautiful mother-of-pearl; this colour pervading more or less the whole fin, which has large yellow maculations. The lower border is rose-coloured like the belly, and the base of the fin also partakes of this general hue. Dashes of milk-white on the base of the anal fin between the rays. Pectorals sepia-coloured with rosy and purplish iridescence.'

There is not really much wonder that the learned doctor should go in for word-painting like this, especially as the subject of his remarks is beautiful in form as well as colour, and nearly all the fishes he had hitherto been describing are black, leaden-grey or livid toad-belly white. But apart from the splendour of this fish, its brief history as one of the American food fishes is a marvellous object-lesson in the climatic influences affecting fish. In 1879 the first catch of a large number was reported as noted above, and throughout the years $1880-82$ the governmental fishery vessels were busy examining the sea for the limits of the new (?) fishes' feedingground and experimenting on the best way of catching them. 



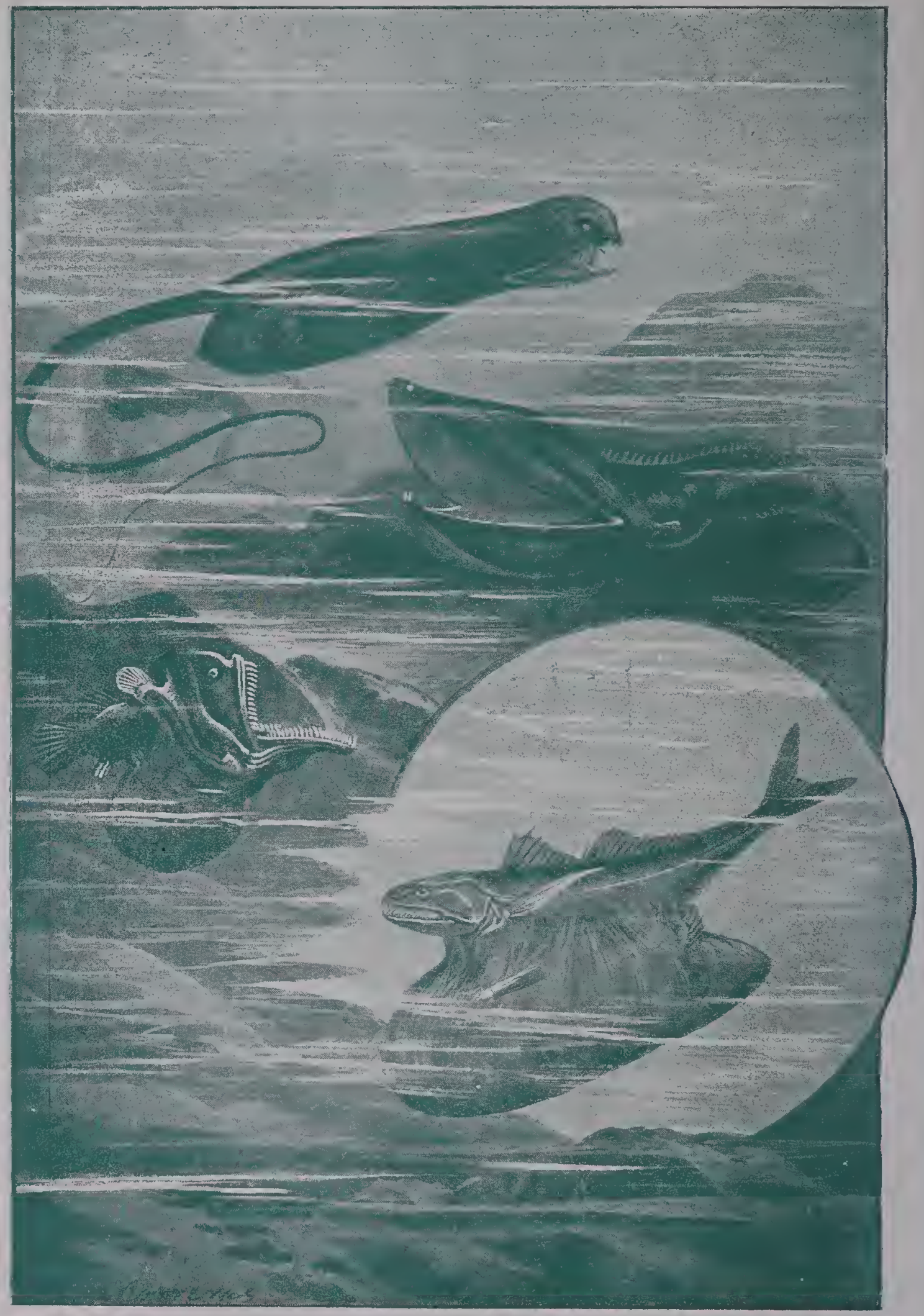

DEEP SEA NIGITMARES.

[Toface p. I6I. 


\section{A Gigantic Holocaust I6I}

But early in 1882 vessels arriving at the NorthEastern American ports reported passing large numbers of dead or dying fish floating over an area of many miles, of which the majority were Tile-fish. It very soon became apparent that an awful destruction of fish had taken place, for vessels reported having sailed through floating fish for forty, fifty, and sixty miles. And in one case, the schooner 'Navarino' reported having sailed for one hundred and fifty miles through waters covered from horizon to horizon with dead and dying fish. There were no signs of disease on the victims, or deadly parasites, and conjecture was busy as to the cause of this wholesale destruction of a newly discovered and valuable food-fish; whether submarine volcanoes, with their concomitants of heat and poisonous gases, or a sudden fall in the temperature, was responsible. Finally, through the researches of Professor Verrill, it was decided that owing to the prevalence of heavy northerly gales and the presence of much coast ice in the north, the normally high temperature of the Gulf Stream and its vicinity had been suddenly lowered, bringing death to countless millions of its sensitive inhabitants. And this theory pressed for acceptance, as there had been no indications of any submarine volcanic disturbances.

So complete did the destruction of the Tile-fish appear to be, that a chapter was devoted to it by Mr. Lucas in the Report of the National Museum (Washington) for I889, on 'Animals Recently Extinct.' For all attempts made by the Fishery Commission vessels to obtain even a single specimen were fruitless. But in 1892 several specimens were obtained in its old haunts, from a depth of between seventy and eighty fathoms of water, thus restoring the Tile-fish to its place on the lists of existing fish of the American 


\section{I62 Deep-Sea Chimæras}

coasts, and it is hoped that in due time it may once more attain to its former abundance.

In concluding this notice of the Tile-fish, I feel that an apology is due to him for classing him at all under the heading of chimæras, from which category his beauty both of form and colour should certainly keep him distinct. The same feeling prevents me from going into details concerning the halibut, various sorts of flounders and soles, and gurnards also, all of whom are found in very deep waters, but are none of them chimæras in any sense. It seems a pity that, now the narrow seas have been so well fished for soles and flat-fish generally that the price of them is becoming prohibitive, there could not be devised some means for fishing those greater depths, in which it seems fairly certain huge supplies of them are to be found, apparently awaiting the coming of usefulness to mankind.

From the foregoing pages many very queer fish have been excluded because of their trivial size. For in tiny creatures both of land and sea we are accustomed to see strange developments of form and colour, and they excite no wonder. If, however, we could find a creature as large as a horse developed into the similitude of, say, an ant, or a bull into that of a beetle, our wonder would be almost beyond bounds. For this reason I have not mentioned the marvellous genus of fishes in the profundities of ocean who carry their own installations of electric light as it were. They are truly amazing, yet not more so than the fire-fly or the glow-worm, and they are all of insignificant size, say from four to six inches long. There is just this difficulty though about dealing with them; it may very well be that the larger ones are too swift and too wary to be taken in the trawls of the fish- 


\section{Little Freaks of Nature ${ }_{163}$}

commission vessels. They may grow in those unknown depths to a very great size for all we know, but we never see them, nor does it appear that we are ever likely to. Unless indeed it were found possible to use a large form of fish-trap, a wicker or wire contrivance, into which fish of quite large size can squeeze their way after the bait it contains but cannot get back again. The entrance is set round with long, flexible, sharp-pointed wires directed inwards and converging to a very small space. The fish, however sluggish, can easily squeeze through, but if he attempt to withdraw, the points of the wires effectually prevent him.

One small species of fish I feel must not be neglected, for several reasons. I say 'one species' although the funny creatures have amazingly differing titles. But they all look very much alike, are all a kind of angler fish, having their mouths apparently cut downward into the head from the top at the front, and possessing a long spine protruding from the back of the neck, with a tassel or a bulb depending from the end of it, which is either a lure for prey or a sensitive organ to warn the owner when buried in the mud, its favourite place, of the approach of a victim. The type is quite familiar to readers of good Natural Histories.

The special characteristics of this fish, however, are well worth noting. First, the enormous depths at which it lives, a specimen having been brought up in the 'Challenger' trawl from a depth of nearly fifteen thousand feet. And in this case, as Mancalias Uranoscopus is essentially a bottom fish, there could have been no possibility of it having entered the trawl on its way down. It was three and a quarter inches long. A larger specimen of a similar fish, though 


\section{I64 Deep-Sea Chimæras}

branded with the epithet Corynolophus Reinhardtii, comes from the deeps off the Greenland coast, but is a more respectable-looking creature, fourteen inches long.

But Melanocetus Johnsonii is really an object of terror, although only four inches in length. When closed, its lower jaw is vertical like the others, but when open it droops below a right angle-the whole front of the fish is, as it were, opened out. And it looks exactly as if the back of its head had expanded into a belly. But that useful organ, having to contain very often a fish much larger than its owner, is a loose sac attached by a cord, which floats about and apparently allows its contents to escape into the body as they are needed for its up-keep. Of course its colour is a uniform black.

Liocetus Murrayi is extremely similar to the foregoing, or would be if the body, apart from the mouth, had not apparently been turned round. Briefly it looks as if Melanocetus had its belly on its back and Liocetus in its usual position.

These few selections may briefly serve to indicate what manner of monsters abide in that mysterious world beneath the waves, a world of darkness and uniform cold, but, we also know, a world teeming with strange life. It gives only just a subject picked here and there from the enormous mass of matter available, but it must be remembered that it really is to that matter what the latter is to the creatures still roaming in their sea-solitudes unknown and, save for one another, unmolested. 


\section{CHAPTER XIV}

\section{SEA-SERPENTS}

VERY simple way of dealing with the subject of this chapter, and one entirely in accordance with my own feelings upon the matter, would be that said to be adopted by the Irish student who was set to write an essay upon snakes in Ireland, and did so in the sentence, 'There are no snakes in Ireland.' But whatever my ideas in this connexion may be, I find it impossible to ignore or set aside contemptuously the vast amount of literature upon the subject, much of it doubtless written by very well-informed and entirely honest persons, who were only anxious to disseminate the truth concerning sea-serpents.

It is hardly possible for any sensible person at all acquainted with the fauna of the sea and literature generally to approach the subject of Sea-serpents with an open mind. It is like the matter of ghosts, one that is mixed up so much with pure superstition, personal bias, human weakness of mind and credulity, that it seems impossible to get a reasonable account at all. And this, setting aside entirely the intentionally mendacious literature on the subject, stuff written falsely from a diseased or riotous imagination with no other object in view than that of creating a sensation, not seldom with the full knowledge that there is always an immense number of otherwise sane and sensible 
persons, who really believe anything they read in print which is not admittedly fiction.

As an instance in point I may quote an experience of my own. Some years ago I wrote a little yarn, which was published in the Westminster Gazette, entitled 'Up a Waterspout.' As I had no intention of gulling anybody, I purposely wrote in a ridiculously inflated style, describing my experiences while being sucked up from the sea surface into the clouds and my subsequent sudden descent. It never even occurred to me that any one could believe the story, it was so obviously absurd. Yet to my intense amazement, when it was included in a volume of sketches I afterwards published, one critic gravely discussed it as if it were true, and descanted upon the unique advantages of such an experience. Now the critic may have been joking ponderously and with 'deefeeculty,' but I do not think he was.

This, however, only by way of introduction to a very difficult subject. Difficult, because it is distinctly unpleasant to realise, as one must do who takes up the Sea-serpent question, how great is the number of people who will, out of sheer wantonness, lie and perjure themselves about some perfectly immaterial matter like this. Any interest possessed by the Seaserpent, if it exists, can only be either scientific or romantic; it has never even been suggested that the creature is dangerous or commercially valuable. Yet an enormous mass of writing can be collected, written by people of almost every European nation, and especially by Americans, whose authors have either admitted, after the sensation caused by their statements has died away, that they were lying for fun, or else all trace of them has been lost, they having invented names and authorities as well as the serpent. 


\section{'Evidence' of Sea-Serpents I67}

Another large amount of printed stuff has been contributed by persons urgently in need of something to do, who have compiled their amazing stories from hearsay. Many of these contributors are clergymen, and it is no exaggeration to say that their stories, having only some casual remarks of a careless seafarer for text, surpass in wildness of elaboration even the yarns invented with intent to deceive.

Then comes a much smaller quantity, the evidence of those who have seen something, and earnestly desire to record what they have seen truthfully, but from inability to describe accurately, or deficient power of observation, or imagination heightened by alarm, or all these reasons (and more) combined, only succeed in misleading. A splendid instance of this is given in the report of a Sea-serpent (?) seen off Portland Light, New Zealand, on August I, I89 I, from the deck of the s.s. 'Rotomahana.' Peter Nelson, a quartermaster, says that the head was like that of an eel. It rose thirty feet out of water. It had fins about ten feet long, situated on either side of the body (which bulged about there) twenty feet behind the snout. It was the colour of an eel on the back, but the belly and fins were pure white.

I have condensed the very prolix report, but this is the substance of it. And I believe that Peter Nelson was a perfectly honest and truthful man who described as best he could the 'breaching' or uprising half-way out of water of a humpbacked whale (Megaptera), an exceedingly common sight on that coast. He says indeed that it was nothing like a whale, but if his description is as accurate as I believe it is, what he saw exactly represents the behaviour and appearance of a humpback gambolling on the sea-surface as usual. Yet because of the lack of previous observation on 


\section{I68}

\section{Sea-Serpents}

the part of himself and others, this Sea-serpent story goes round the world and is published in many newspapers. It is also used triumphantly by Professor Oudemans, Director of the Royal Zoological Society at The Hague, as a convincing proof of the correctness of his theory of Sea-serpents.

There lies before me as I write a portly volume of six hundred pages, with many illustrations, compiled with amazing industry and perseverance by this learned gentleman, apparently for the sole, and to him sufficient, purpose of buttressing his theory as to the nature and character of the Sea-serpent, of whose existence, by the way, he has no doubt. Only, the creature he has evolved for his own satisfaction from the mass of material he has so carefully collected is not a serpent at all, but an amazingly developed mammal of the sea tribe, a Pinniped, to which he boldly assigns a length of two hundred and fifty feet. If it were not for the many instances given in this volume of the amazing crefulity displayed by scientific men when in the presence of some extraordinarily gifted romancer (vide the British Association and M. Grien's stories if flying wombats, saw-fish in inland lakes, turtleriding, etc.), I should feel disposed to be quite contemptuous about Dr. Oudemans' 'conclusions.' But apart from his scientific credulity, he displays a really touching anxiety to extract from the mountain of lies, absurdities, and superstitions he has collected with so much labour, a sufficient number of grains of truth for the putting together of his pet sea monster. As to his rejection of other scientific theories of the Sea-serpent, I make no account of that. $\mathrm{He}$ only deals with rival theorists after his kind. It seems to be rather a feature with scientific men of a certain class to build a theory first, then mould the evidence 


\section{Origin of Sea-Serpent Stories 169}

or suppress it to fit the theory, and ignore utterly any other explanation but their own.

The list of what Dr. Oudemans calls 'would-be Sea-serpents' is a fairly large and comprehensive one. Seals, cuttlefish, sharks, porpoises, fossils (Zeuglodon and Basilaurus), and even albacore; the physalis, a rorqual, and a supposed marine plesiosaurus are among the living (?) creatures, while sea-weed and floating tree-trunks are among the inanimate simulators of the great snake. But he evidently does not relish the idea that any of his contributors have called upon their imagination to stimulate pen and pencil, except where confession of detection has exposed the fraud. This may seem harsh, but what else can be said of a scientific zoologist of the present day, who deliberately quotes Olaus Magnus, Archbishop of Upsala, and Pontoppidan, Bishop of Bergen-two clerics remarkable for nothing greater than their most amazing credulity and riotous imagination? A quotation from our author must be given as showing the position he takes up with regard to the latter of these two ancient fictionists.

'We see the Bishop weighing and considering whatever he heard, and not accepting everything for truth. We think that Pontoppidan is right in giving no credit to the narrative that the Sea-serpents made themselves guilty of sinking ships and eating men. . . . Pontoppidan further tells us that the Seaserpent sometimes encloses ships by laying itself round them in a circle, that the fishermen then row over its body there where a coil is visible, for when they reach the coil it sinks, while the invisible parts rise. Further, that the Serpent swims with an incredible velocity, and that the fishermen, who are much afraid of it, when seeing that it follows them, throw any object, 
for instance a scoop, at it, when the animal generally plunges into the deep. But most fishermen are in the habit of taking castoreum with them, for the Serpent cannot abide the smell of it. ... And in his tenth paragraph, trying to answer the question why those larger serpents only frequent the northern seas, he says: 'To this question I answer that the Creator of all beings disposes of the dwellings of His creatures in different places by His wise intentions, which are not known to us. Why won't the reindeer thrive anywhere but in the high and cold mountains? Why do the whales frequent only the North Pole? (!!) Why are India and Egypt almost the only countries where men have to fear crocodiles? No doubt because it pleases the wise Creator!' Here Pontoppidan takes leave of the Sea-serpent, and begins to treat of the large snakes mentioned by Plinius and other ancient authors, and we too will take leave of our honest and trustworthy bishop, who has so often been laughed at for what he relates in his chapter on monsters. And yet two of his monsters, the mermaid and the kraken, being unmasked, why cannot his third be accounted for?

It should not be forgotten that the date of this delightful book is 1892 ! The author quotes, with evident approval, Olaus Magnus writing in I555-

' They who, either to trade, or to fish, sail along the shores of Norway, relate with concurring evidence a truly admirable story, namely, that a very large Serpent of a length of upwards of two hundred feet, and twenty feet in diameter, lives in rocks and holes near the shore of Bergen; it comes out of its caverns only on summer nights and in fine weather to devour calves, lambs, and hogs, or goes into the sea to eat cuttles, lobsters, and all kinds of sea-crabs. It has 


\section{Superstition and Sea-Serpents I7I}

a row of hairs of two feet in length hanging from the neck, sharp scales of a dark colour, and brilliant flaming eyes. It attacks boats and snatches away the men, by raising itself high out of water, and devours them ; and commonly this does not happen without a terrible event in the kingdom, without a change being at hand, either that the princes will die or will be banished, or that a war will soon break out.' The only criticism of this amazing yarn which the Professor permits himself is-'We consider its devouring hogs, lambs, and calves, and its appearance on summer nights on land to take its prey, to be a fable. The eating of squids, cuttles, crabs, and lobsters may be a fiction or it may have been truly witnessed, the animal chewing them with its head above water, as seals and sea-lions do (!!). The story of snatching a man away from the ships is evidently confounded with another tale. . . It of course refers to gigantic calamaries which occasionally attack boats and snatch away one of the crew. Its being covered with scales must be fictitious too, for they who saw a Sea-serpent at a short distance are unanimous in stating that it had no scales, but a smooth skin.' A fine example of the gnat and camel parable, surely.

The list of accounts of the seeing of the Sea-serpent fills nine pages and a half of our author's book, and date from 1555 to 1888 . Apparently no yarn, however wildly absurd, is excluded or refused rank as evidence, unless it has been exposed as an indubitable fraud. Even then Dr. Oudemans cannot help adopting a regretful tone, as if he only wished that the story was true, or that it had not been discovered to be false, so that he might have the luxury of believing it. But of all the amazing stories collected by the learned Doctor, none attain such a magnitude as the following. 


\section{Sea-Serpents}

In I845 Dr. Albert C. Koch exhibited a large skeleton of a fossil animal under the name of $H y d r a r c h o s$ Sillimanni, the latter half of the portentous name being in honour of the learned editor of The American Journal of Science and Arts, Professor Benjamin Silliman, well known for his affectionate regard for the Sea-serpent. The remains consisted of a head and vertebral column, measuring in all one hundred and fourteen feet, of a few ribs attached to the thoracic portion of the spine, and some parts of supposed paddles. Of course the scientific journals took up the discussion of this wonderful discovery with avidity, and a few months afterwards Professor Wyman, in The Proceedings of the Boston Society of Natural History, had the courage and skill to point out that 'these remains never belonged to one and the same individual, and that the anatomical character of the teeth indicates that they are not those of a reptile, but of a warm-blooded mammal.' In the next month's Proceedings of the same Society, Professor Rogers points out that, according to the form and structure of some loose bones, the skeleton must be of at least two individuals of Basilaurus, a fossil monster allied to the seals and whales, which Professor Owen termed Zeuglodon. In the next month's issue Dr. Koch informs the public that the bones had been found together and were arranged in the precise order in which they were discovered. But a Dr. Lister wrote to say that he knew that Dr. Koch had dug up the bones in different places in Alabama.

However, the yarn was not killed, hardly scotched, and the 'fossil Sea-serpent' still yielded a plentiful harvest of dollars. And in The Illustrated London Neres of October 28, 1848, Professor Silliman ventures to state, in the hope apparently that the previous contradictions would be forgotten, " that the spinal column 


\section{Astute American 'Professor' I73}

belongs to the same individual, that the skeleton differs, most essentially, from any existing or fossil serpent, although it may countenance the popular (and I believe well-founded) impression of the existence in our seas of huge animals, to which the name of Sea-serpent has been attached.'

Now the facts of this case undoubtedly were proved to be as follows :-

Dr. Koch was a collector of fossils, but entirely unscrupulous in the use he made of them. He was a business man first, and a scientist afterwards (a long way). Not satisfied with the real scientific value and interest of the wonderful collection of American fossils he really possessed, he, seeing what a valuable show it would make, deliberately faked the said serpent out of bones of several Zeuglodon, made a head and claws to suit, and then having hitched his fraud to Silliman, put it on public exhibition. And no doubt his enterprise was considered to be a real smart one, an evident token of high business capacity, quite unusual in a scientific professor.

Sober investigators, like Dr. Andrew Wilson, Mr. Lee, and Mr. Gosse, all being gifted with sound commonsense, as well as having high scientific attainments, do not waste time over the many obvious absurdities and palpable fabrications which are so plentifully quoted in Dr. Oudemans' book. But they have given much time and careful investigation to such stories as bore the stamp of truth, in so far that it was manifest that the observers had seen something out of the common, but had quite naturally in their excitement gifted the vision with some extraordinary attributes which it never really possessed.

Of these stories the most interesting is that told by the captain and crew of the 'Pauline.' Captain 


\section{Sea-Serpents}

of, say, at the outside, twenty tons in weight, to swallow a morsel of eighty or one hundred tons! Indeed we might well expect him to lie many months in a state of coma. In truth, Olaus Magnus or Pontoppidan never bettered this yarn, though they were far from being amateurs at the task. And it was sworn to.

There are also the stories of the ministers who saw the Sea-serpent in the Sound of Mull and estimated its length at sixty feet. They did not expect to be believed, and said so, only they felt that any explanation of what they saw except that it was a great Seasnake was impossible to accept. But the most difficult story of all to account for is that told by Captain McQuhae of H.M.S. 'Dædalus,' and his officers, which in I848 created so great a sensation in England. Very briefly, the story is that, in lat. $24^{\circ} 44^{\prime} \mathrm{S}$., and long. $9^{\circ}$ $22^{\prime} \mathrm{E}$., an enormous serpent was seen, its head and shoulders some four feet out of water, and quite sixty feet of its body on the surface. It passed rapidly without any undulatory movement, so close to the ship that the gallant captain says he could have distinguished a man's features at the distance. It had no fins, but something like seaweed washed about its back.

Now it is not fair to suppose that the captain and his officers stated anything that they did not believe to be true, yet no less an authority than Professor Owen in a long letter to The Times of November II, I848, points out that the captain's observations and his conclusions do not fit at all, finally giving it as his (the Professor's) opinion that the thing seen was a great seal or sea elephant ; much to the captain's annoyance, who replies very warmly to the great palæontologist's letter. Another authority gives it as his opinion that the creature was a huge basking 


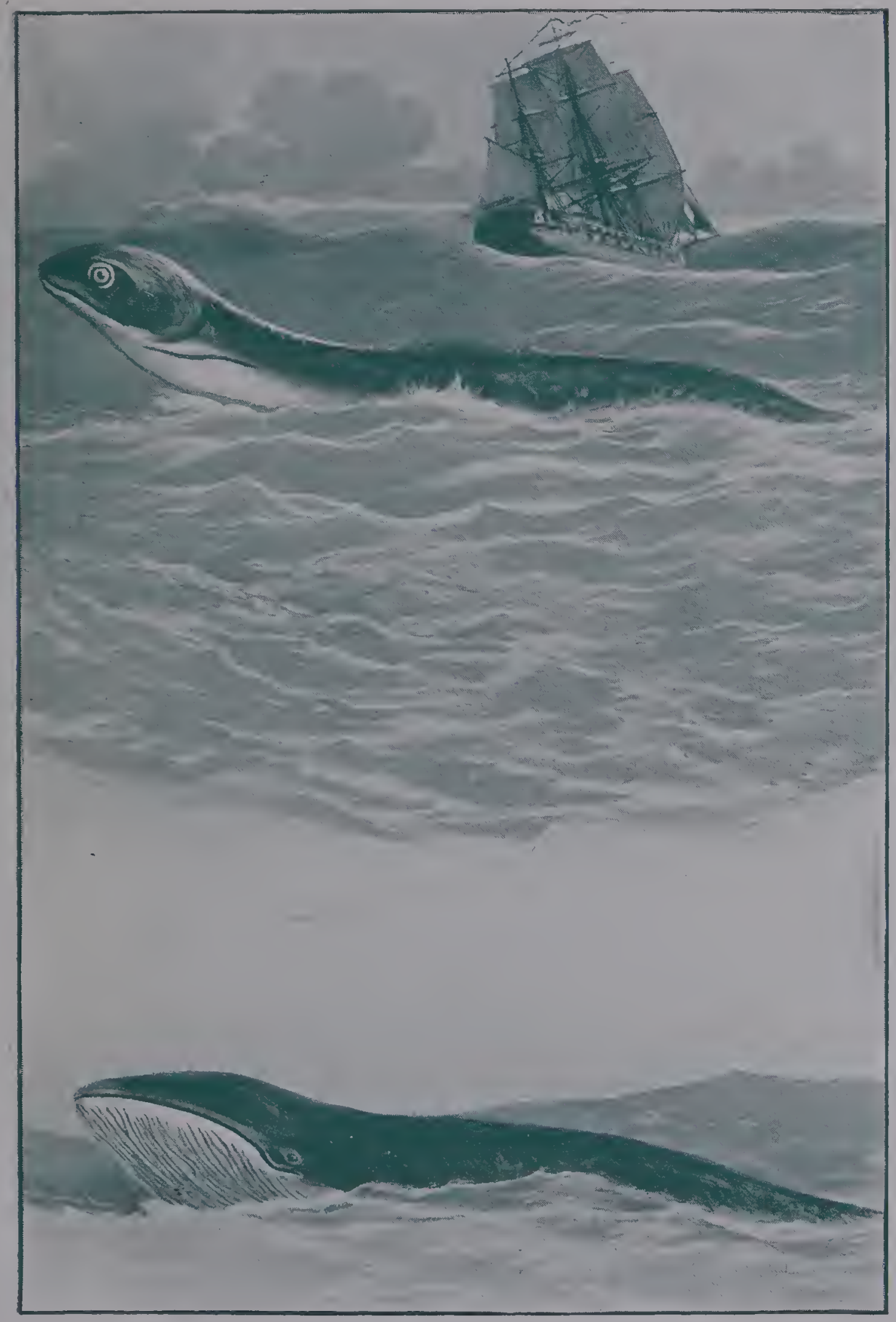

THE 'DAEDALUS' SEA-SERPENT, AND ITS MOST PROBABLE EXPLANATION.

[To face p. $1>6$. 



\section{Incredulity of High Authorities 177}

shark, such as another well-authenticated serpent stranded at Stronsa and given as sixty to eighty feet long was proved to be and reduced in length by about one-half. For myself, I believe that the officers of the 'Dædalus,' being, like most sailors, very careless and casual observers of marine fauna, did see a huge sulphur-bottom whale (Balaenoptera sulphureus), which is slender, has a comparatively small head, attains a maximum length of one hundred and fifty feet, and a speed of sixteen knots.

But any attempt to show that the tellers of some Sea-serpent stories were truthful and honest, according to their lights, only seems to arouse animosity among those curious savants who appear to think life would not be worth living without belief in a gigantic snake. They will not hear of any natural explanation of the strange sights reported by veracious seamen, and entirely ignore Professor Owen's calm dictum, that had Sea-serpents of the dimensions so often given existed, some remains must have been found, for such creatures would be often on the surface to breathe and could not fail to have deposited relics of themselves on some shore or other. Only one joint of a vertebra would have been sufficient, says the Professor, to have established the Sea-serpent's identity scientifically. But that illuminating fragment has never been forthcoming.

It has been assumed that the Zeuglodon is not extinct, although a recent specimen has never been found, and the fossils are found in the tertiary deposits. It is also assumed that the creature may be a Plesiosaurus, which has survived the lapse of ages in that mysterious realm, the depths of the sea. But certainly none of the Sea-serpent stories, honestly told, are insusceptible of feasible logical explanation by those 
acquainted with our larger sea mammals and other fauna not usually seen.

Are there then no Sea-serpents? Certainly there are, very many, and exceedingly dangerous ophidians they are, being highly poisonous. The largest of them is almost as thick as a man's leg, and from eight to ten feet long. They abound on the Indian coasts, and in the Eastern Archipelago I have often seen them pursuing their devious way along the calm surface. They all have a flattened end to their tail, instead of its coming to a point, as does that of all the land snakes. I have heard, on good authority, they are responsible for the deaths of many Lascars in the country vessels of India, climbing up the coir hawsers with which the vessels are anchored, through the hawse-pipes and biting the sleeping men.

But these are not the Sea-serpents whose characteristics, as seen by latter-day chroniclers, all bear the stamp of Olaus Magnus or Pontoppidan. The enormous length, serpentine shape, mane of hair, side paddles, etc., all bespeak a common origin. Now it would ill become any one, least of all those knowing something of the fearsome creatures that have of late years been found to inhabit the great depths of the sea, to say that we shall never find or see any terrific monster upheaved from the ocean floor. Only, if such there be, it will not be a serpent, or a mammal such as Professor Oudemans believes in, a sort of Zeuglodon two hundred and fifty feet long. Because these creatures are essentially of the surface, they cannot even descend to any great depth, in consequence, first, of the increasing pressure upon their bodies, and next, of their need of air breathed direct from the atmosphere.

I firmly believe myself that cuttle-fish lurk in the 


\section{Sea-Serpents and Religion I79}

darkling caves of ocean, a sight of which would justify any Sea-serpent yarn, however Munchausenlike, and I should not like to question the existence of enormous individuals of Regalecus or oar-fish, of which Dr. Goode says that "it seems quite safe to assign to this group all the so-called Sea-serpents which have been described as swimming rapidly near the surface, with a horse-like head raised above the water, surmounted by a manelike crest of red or brown.' But from a Regalecus of twenty feet long to a Sea-serpent capable of carrying his head sixty feet out of water is so long a step that I do not think we shall ever take it.

The great difficulty about our acceptance of Seaserpent stories to-day is the aroma of mediæval superstition which surrounds them. We cannot help remembering that there belongs, as of right, to all Seaserpent stories of the Olaus Magnus order, a relationship to serpent worship, to the hideous old mythologies of the past, having, if not their origin, at least their early history enveloped in a mist of blood and human agonies. We may interest ourselves in serpent lore connected with religion as much as we will, and find it terribly interesting, if only from the fact that almost all early religions have some trace of it. That in the case of peoples who knew the sea the fabled Sea-serpent should become of vast and awful size and aspect, was perhaps only natural, since the connexion of it with the sea, itself a place of superhuman dread and mystery, became perhaps inevitable. The avatar of the fish from the Mahabarata of the Hindus is a case in point, elaborated with all the fulness of grotesque detail that these ancient people love, as well as a boundless exaggeration. The puny efforts of our romancers must recede into obscurity before the tale of a Sea-serpent a million leagues long, and 


\section{I80 Sea-Serpents}

with a stupendous horn reaching from its forehead to the clouds.

There is another thing which does not seem to strike believers in Sea-serpent stories, such as the learned Professor from whom I have quoted so largely. And that is, that of the Sea-serpent so often described, which I must call, for want of a better term, the Olaus Magnus, or conventional Sea-serpent, no trace has ever been supplied to the examination of naturalists. Certain remains have been found, as, for instance, those of the Animal of Stronsa in Orkney, about which so furious a controversy raged nearly a century ago. It was discovered in October I808, on the rocks in Rothiesholm Bay; its measurement in length was solemnly sworn to by three witnesses as having been proved by themselves at fifty-five feet, and anatomical details were given at great length to prove that it was a veritable Sea-serpent.

Mr. Everard Home, then the greatest living osteological authority, went to Orkney at once and examined the remains in the interest of science. His report was clear and distinct enough to satisfy the most exact seeker after truth, and considering the status of the gentleman making it, who could have no other interest in the matter than that of arriving at the facts, it should have settled the controversy. He gave his evidence unhesitatingly that it was a Squalus maximus, or great basking shark, which did not exceed thirty-five reet in length, and presented no difficulty even in an advanced stage of decomposition in the determination of its character.

After sufficient time had elapsed the whole question, which had been thought to be finally settled, was again raised. Mr. Everard Home's scientific testimony was thrown overboard, and the evidence of the illiterate 


\section{'The' Sea-Serpent Non-Existent I8I}

fishermen who had measured the body with a one-foot rule, and had made all manner of wild statements about it having six legs, both ends alike, etc., etc., was reinstated, and gravely discussed de novo by quasi-scientific gentlemen who should have known better.

In conclusion, although it is not necessary to give a list of all the various appearances which have simulated the Sea-serpent for excited observers, it may be stated with the utmost plainness that none of the reports of Sea-serpents made yet have been such as would stand a cross-examination without revealing their true explanation or their true origin as fiction pure and simple. And this may be truly said, without in the least denying that the civilised world may one day be startled by the appearance of some vast and hitherto unknown monster from the depths of the ocean. 


\section{CHAPTER XV}

\section{THE ALBACORE}

$T \mathrm{HE}$ subject of the present chapter is a very king of fish. Without controversy, he is the head of the vast mackerel family, the Scombridae, of which our well-beloved mackerel is perhaps the best-known exponent in the whole world. But, perhaps, it would be better, seeing how varied are the Albacore's adventures, how vast is his range of habitat, and how different are the names by which he is known in various parts of the world, to let him tell his own story, after a very brief description of his majesty's person.

First, then, imagine if you can, a mackerel who, by some extraordinary process of development, has attained a length of say six to eight feet. But, in doing so, he has not retained that slender elegance of outline characteristic of the common mackerel; he has put on a disproportionate girth, so that given a length of seven feet he will often be five feet in circumference. In colour he is a steely blue with lighter shadings, until on part of the belly the colour is almost that of burnished silver. His fins, which are almost exactly the same shape as in the common mackerel, but proportionately larger, are golden in hue, and glitter in the sunshine when he is near the surface with an almost intolerable brilliancy to the eye. On both sides of the body, commencing at the pectoral fins and about midway between back and belly, is a wavy line, almost black 


\section{The King Mackerel}

for the anterior third of the body, then gradually developing into a series of conical horny protuberances, as if the fish were developing an armour-plating like the sturgeon. All mackerel possess this curious line of scaly excrescences, and all mackerel, although not absolutely without scales, have very few of them, and what they have are covered with a fine, tough, and transparent skin. Most of the scales are plated around the shoulders of the fish, where, too, the hues are deepest.

The head is of an almost ideal shape for a fish, of perfect curves, and with a clean-cut, tightly closing mouth, whose bony jaws, apart from the rows of needle-sharp teeth, are quite as effective in dealing with prey as the snap of a pair of tailor's shears would be, operated with the same force that this vigorous fish can exert. The eyes are two splendid orbs, averaging two inches in diameter, and so set in the head that they give an almost perfect range of vision, being also slightly prominent and entirely unshaded by lids, brows, or membrane. Their colour I am not quite sure of, but to the best of my recollection it is an intensely dark blue for the pupil, with a surrounding rim of gold.

The food of the Albacore is living fish of any kind, not too large for his devouring, but is principally composed of the leaping squid (Loligo) and flying-fish. It is in pursuit of these latter that he exhibits that amazing agility for which he and the coryphaena are famous, an agility almost incredible to witness. I am quite unable to assess the rate at which an Albacore can travel, but I should certainly say that when I have seen him darting along just beneath the surface of the sea, following a flying-fish cleaving the air overhead at top speed, that it has not been less than 


\section{I84 The Albacore}

thirty miles an hour. And that he maintains that speed for distances of over a thousand yards broken into several different directions, as the flying-fish changed its aerial course in order to try and dodge its deadly foe. Also, I have repeatedly witnessed its dash into a school of its smaller relatives, the skipjack, like a flash from the mouth of a gun, and, zigzagging back and forth so rapidly that the eye could scarcely follow it through the bewildered school, leave the sea over a large area befouled with blood and fragments of mangled fish, which the survivors, immediately upon their enemy's departure, bestirred themselves to devour.

Paucity of food it apparently never suffers or can suffer from, its natural prey being so wondrously abundant wherever it roams. And in consequence a poor, thin, and weak Albacore is never seen. Perhaps such an one would be promptly devoured by its extraordinary ravenous congeners. The strength of the Albacore is as amazing as its speed. I have seen a strong man's arms completely paralysed in one minute through trying to hold a very small one, only twentyfive pounds in weight, with his fingers clutching its neck and his thumbs thrust into the gills. The hot, black-red blood literally boiled over his hands as the dying fish's vibrations shook him like some great galvanic battery. And for hours after he was unable to use his arms in any way.

Its extreme limit of size is, of course, indeterminate, but there are fairly authentic records of individuals having been taken off Sicily of twelve hundred pounds' weight. In the world-renowned tunny fisheries of the Italian and Sicilian coasts, where they are known as the Tunny, they are probably found larger than anywhere else. As the Tuña, they are well known 


\section{A Great Fighter}

I 85

on the Californian coast, and afford perhaps the acme of angling sport, testing the angler to the extreme limit of his endurance. But I never heard of one larger than eight hundred pounds' weight being caught there. In the deep sea, as far as my experience and information go, they are seldom seen larger than say a quarter of a ton, but that is perhaps because the largest specimens do not consort with ships as the ordinary sized ones do.

The largest one I ever had intimate acquaintance with was in Carlisle Bay, Barbadoes, where I was fishing for flying-fish in one of the locally owned craft. We had been most busily employed baling up the swarming Exocetae, and had between two and three thousand of them in the boat, when there was a blaze as of silver sheet lightning in the water, followed by a swiftly passing shadow, and the water was absolutely void of fish where a moment before there had been millions. The skipper of the boat, knowing well the cause of this sudden flight, snatched up a stout line that lay ready coiled on the after-thwart, impaled a flying-fish on the big hook, and, tossing it overboard, gave the boat a sheer off the light air that was just ruffling the surface, and we began to gather a little way, the line streaming astern. Hardly a minute had elapsed before there was a yell from the helmsman, and looking aft we saw the line taut as a harpstring. The boat began to move astern against the wind, and we all tailed on to the line. But as we could not get an inch of it, we led it to the bow and secured it there, in order that our fish might tow us properly. We had no fears for either line or hook. So for an hour that big mackerel towed our ten-ton sloop whither he would, winding up his tremendous exertions by a splendid fighting end in the middle 


\section{86}

\section{The Albacore}

of the bay amongst the shipping. We could not get him on board, so we secured him by a double bight of the line round his tail, and towed him into the harbour, where, by the aid of a cargo-crane, we landed him on the quay. He scaled four hundred and seventy pounds, making a goodly sum for the poor fishermen who peddled him round the town on a truck. The gallant struggle he made for life and liberty has often been recalled to my memory in reading angling experiences with the Tuña in California. What must be the prowess, endurance, and skill of an angler who, in a small boat with one assistant, a slender rod and a fine line, can succeed in securing a monster of the deep like that.

To my great chagrin I have never succeeded in catching an Albacore. Many times, when fishing for bonito from the jib-boom of a ship, I have hooked Albacore weighing from forty to over a hundred pounds, but never succeeded in pulling them up high enough to drop them in the gaping sack. And I was never quite sure when I had them on the hook whether I would rather get them up or see them drop off, seeing what formidable creatures they are to manipulate when in their full vigour, even on deck. Astride on that slender spar twenty feet out ahead of the ship, I had always a feeling that the holding of one would most likely result in the swift descent of the pair of us into the seething bow-wave ahead of the ship. Once I hooked one in almost a flat calm by dangling my hook with a piece of polished tin for a lure from the jib-boom. He was so heavy that I could not lift him, so I played him until I was quite exhausted, and then, bitterly disappointed, had to hand him over to others. He was eventually secured when fagged out by a man being lowered over the side and slipping 


\section{A Mighty Traveller 187}

a running bowline over his tail. $\mathrm{He}$ weighed one hundred and twenty pounds-a mere infant.

The range of the Albacore, Tunny, or Tuña, is over all the oceans and seas having access to them within the temperate zones. The farthest north that I have ever seen one was $40^{\circ}$; but, like the other pelagic deep-sea fishes, their range north and south within certain limits depends upon the temperature. I saw flying-fish in 1902 in $48^{\circ} \mathrm{N}$. while crossing the Atlantic from Liverpool to the Gulf of St. Lawrence in August, and was much surprised, for I had not hitherto believed it possible for the Exocetus to exist so far outside the tropics. Unlike the majority of the deep-sea pelagic or surface fishes, the Albacore's places of spawning, for the Atlantic at any rate, are very well known. It is in the Eastern Mediterranean and the Ægean Sea, for which purpose the Albacore migrates thither in countless thousands, and by so doing supplies a large proportion of the Provençal, Italian, and Sicilian coast population with profitable employment and cheap food, while Tunny tinned in oil as a luxury of the table is sent to the whole of the civilised world at a fairly high price. And now, having thus introduced my interesting friend collectively, let him tell his life-story as an individual.

Very lovely and comfortable were the surroundings in which I first emerged from the pearly round egg, one of many millions deposited in the same area by our parents. It was off the northern shore of the rocky island of Khelindromi, on the western side of the blue Ægean Sea. You know the place, perhaps; that is, above water-know it for one of the most picturesque spots in the archipelago. But you cannot know-you never will know-how exceedingly beautiful is the scene below, about the bases of those quaint 


\section{88 \\ The Albacore}

rock masses, whose summits are crowned by eyrielike villages, accessible only to goats and island mountaineers, who descend from these amazing fastnesses for the fishing with as much caution to-day as they did when every village of the kind was a pirate stronghold whose denizens preyed upon any neighbour with strict impartiality.

Moreover, you do not, cannot know of the treasures lying hid in those dim depths, you can only faintly guess. But a thousand years of warfare and piracy carried on in the vicinity of the richest and most artistic nations of the old world has made almost every foot of the sea-bed within a few miles of land a veritable storehouse of wonderful wealth in precious metals and almost equally precious artistry. Around groups of marble and bronze statuary, amid heaps of gold, silver, and gems, twine the beautiful red, pink, and black coral, palpitate the masses of living sponge, at such depths as no diver has yet reached to return living.

And amidst all this splendour, on cunning little plateaux of silvery sand in level nooks floored with powdered lava, in alcoves paved with coral fragments ground small by the never-ceasing attrition of the waves alone, I and some millions of my fellow Albacores were born. I did not then know, as I have learned since, that in this spot as in every other where fish are hatched, there were hosts of the baser sort of fish, yes, even as low as the Medusae, those backboneless masses of jelly that can hardly be said to live in the sense that we higher organisms do, waiting to devour us as soon as we had attained an independent existence, all hampered as we were by the sustaining yelk attached to our waists during the first two days of our lives. We had no protectors; if our parents land been there 


\section{Early Training}

I 89

they would have devoured us with as great if not greater rapidity than our present foes did; but we had one safeguard, had we but known it: our innumerable numbers. It was impossible for the most energetic, the most voracious of our enemies to destroy us, not merely all but more than half of us. And this law, if I may so call it, of superabundant supply, is what really prevents the utter annihilation of many species in the sea.

So it came to pass in due time that, evading the destroyers in company with some millions of my brethren, I grew and waxed strong enough to eat in my turn, not only the young of other fish which swarmed in our deep retreat, but any of my own family that happened to be less agile or weaker than I was. For in me, as in my fellows, but one principle, one law held sway, and guided as yet all actions. It was to live, and in order to live, to eat, never mind who or what, so long as it was eatable. Our one aim, our one duty, was to grow and get big; we did not know why or how, but we obeyed the overmastering law.

In due time we began to stray farther and farther from our birthplace into deeper and deeper water, always under the same mysteriously compelling impulse, until at last, having grown into a sizeable fish of about three pounds in weight, I headed a goodly company of my fellows in a straight course westward out of the Middle sea, nor rested until we found ourselves out in the vast expanse of the Atlantic Ocean. How we rejoiced in our new-found freedom from the constant terror of enemies! Here they hardly troubled us at all, or if they did we felt easily able to elude pursuit, being so agile and cunning from our early training. Several times, however, I had narrow escapes through falling in with adult individuals of 
our own race, who sought to devour us without giving us a chance of escape. Many of my fellows who had braved the innumerable dangers of infancy with me fell victims on these occasions. So we gradually separated, some were eaten, more strayed away, independently gathering their livelihood from the abundant sea, but all who survived were growing with astounding rapidity, and preparing to take their place in the royal ranks of the great Albacore.

Could I but detail to you the events of the next two years, they would fill a goodly volume of hairbreadth escapes and amazing travel. I cannot claim to have visited any profound depths, for our people are essentially surface-fish and do not descend deeper than one hundred fathoms. But within that limit I have, I think, explored most of ocean's fastnesses, braved most of the dangers that await our people. Many days did I linger about the base of St. Paul's Rocks in the North Atlantic eating my fill continually of all species of deep-water fish smaller than myself, who were utterly unable to escape the clash of my unerring and lethal jaws. Here I learned to avoid the fearful toils of the brooding cuttle-fish, having torn myself free from the deadly touch of an arm of one of these monsters crouching in a darksome cave. Here, too, by a turn of my body, almost as swift as light, did I avoid the thrust of a giant relative of mine, a sword-fish, whose weapon grazed my body along its entire length, leaving a wide white weal whereby I became known and identified in after years, not merely by mine own people but by men.

But I escaped all these dangers, as did many of my fellows born at the same time in the Egean, and ranged the waters of Mid-Atlantic as being in my rightful realm, a veritable sovereign of the sea. I 


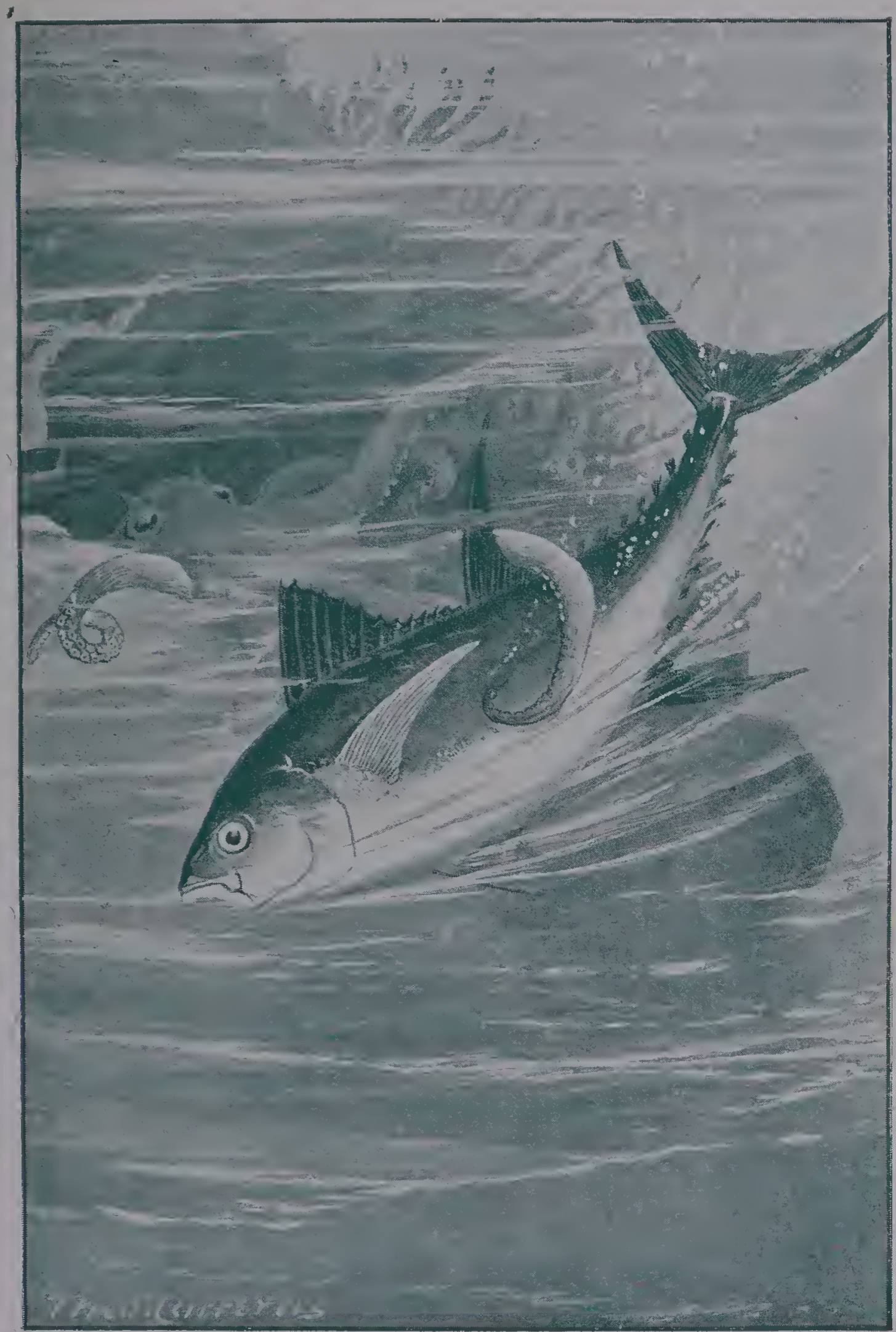

THE ALBACORE'S NARROW ESCAPE.

[To face $p$. Igo. 



\section{Adult Joys}

\section{IgI}

skirted the vast masses of myriad-tenanted weed that go to make up the curious ocean eddy known as the Sargasso Sea, and many a quaint fish found its way down into my ever-ready stomach as I prowled around ready for stragglers, yet not daring to venture too far into that dense entanglement, sacred to the upbringing of an incalculable number of young sea creatures, because of its security against such sturdy marauders as I had now become. I learned that ships might be safely consorted with, and usefully too, because of their pleasant habit of scaring up the smaller creatures upon which I loved to feed, but on several occasions I very narrowly escaped destruction, by missing a lure let down before my dazzled eyes by some hungry miscreant on board one of these floating things.

But I shall never forget an experience I had, which I think did more to round my girth and stiffen my sturdy frame than any other. It was in the North Atlantic too, on the south-western verge of the Sargasso Sea. I had been hungrily pursuing a vast school of flying-fish, and occasionally snapping up a straggler or two that only served to make my hunger more acute, when I suddenly darted into a vast black shadow (it was blazing noon), in the cool of which it seemed that all the edible fish imaginable were congregated. I swam leisurely to and fro, and filled my maw almost to bursting, then languidly surveyed my surroundings. I found that I was beneath a wooden ship, deserted of her crew for long, yet so buoyant by reason of her cargo that she could not sink. Upon her sheltering planks had clustered an immense mass of sea-growth, weed, barnacles, limpets, and so forth, and of course these had attracted to themselves, as offering easily obtained food, an enormous number of fish, both 


\section{2 \\ The Albacore}

vertebrates and crustacea. These in their turn had invited the attendance of larger fish like myself, until the whole area of sea around that nearly submerged aull was literally alive, and all the population were busy feeding upon one another. It was a delightful time for me, for I was very nearly immune from pursuit by any of the others, being so large. But I narrowly escaped annihilation here one day. Prowling leisurely about, sucking in dainty morsels to titillate an already overcharged stomach, I saw shining before me a white cavern, down which many fish were swimming eagerly as if in chase of some prey. I was minded to follow, and but that I was lazy with repletion would have done so. However, I turned away carelessly, just in time to note that the cave turned almost as if upon an axis, the entrance closed, and a vast black mass, the body of a sperm whale, ascended to the surface. A very narrow escape indeed, but one that did not affect me at the time any more than it would have affected me had I been one of the visitors to that cavern.

Many a ship did I interview on my long cruise in the North Atlantic, but to none did I adhere closely, for it is not the custom of our people. I loved to follow the ships and swim round them, for I saw how they stirred up the squid and flying-fish upon which I loved to feed, but it was exceedingly seldom that I came near enough to one of these floating masses to discern its outlines, much less to incur any danger from heldout lures. I was not yet old enough to be so venturesome. In due time I went round the Cape of Good Hope, forgathering as I did so with a multitude of queer fish on the great Agulhas Banks. In sooth, that was a goodly time. None of those fat cod and steinbrass had any fear of me, or seemed to regard 


\section{Tropical Experiences}

me as an enemy, the while I scooped them into the profound and never-to-be-satisfied cavity of my stomach.

I was well-minded to make that my home, deeming it best in all the seas I had yet visited, but I could not endure the cold, the deadly chill that, creeping up from southward, seized upon me and made me helpless when I would fain have been most helpful to myself. So I bade farewell reluctantly to my good friends and hosts who had fed me so bountifully upon themselves, and made my quiet way northward across the Indian Ocean. Ah, that is a pleasantly prolific sea! For growing fish like myself there is none better, if one does but keep a wary eye lifting for the sword-fish and the grampus, who alone of all the fishy kind can give such as I am an uneasy moment. Many months I lingered in those quiet waters, feeding, ever feeding, and growing apace, so that I began to wax prideful, and wonder if in all the wide sea there was ever seen an Albacore like me.

Presently I won to the intricacies of the Eastern Archipelago, which queerly reminded me of my birthplace except for the strange currents that roared and eddied round about those clustering isles and reefs. But for food! They simply swarmed with all that I needed or desired, and I fed me full and grew lazily fat, as if in all the seas I alone was being fed, I alone had a claim upon the Power whose provision had arranged for the sustenance of His humblest creatures.

Throughout the whole of that vast network of reefs, submerged volcanoes, and island bases, I roamed with never a care. Always I kept the same watchful outlook for mine ancient enemy the sword-fish, whom alone, of all the deep-sea folk, I now dreaded; always I bore in mind that to enter any cavern, however 


\section{I94 The Albacore}

enticing its opening seemed to be, might very possibly mean that out of it I should never come again, since it might be the throat of a sperm whale, or it might contain in its deep recesses a network of living arms, from which I could in no wise escape. And I grew so fast, girth and length increased amazingly, and as for my strength, I did not know its greatness, except that I could, and often did, hurl myself high into the sunblaze after a fleeing flying-fish, descending swiftly with him between my jaws, full of exultation at my own achievement.

Here I met with almost all that our levels of the ocean hold of strange sea monsters, and held my own among them with utmost pride, for I feared none. Indeed, I was almost too haughtily careless, for, despising the prowling Pristis, or saw-fish, I once almost allowed a vast creature, three times larger than myself, to rip me asunder from beneath, as, swiftly gliding like a black shadow he changed from the dull attitude of lethargy he was assuming as I passed him so carelessly. Thenceforward I held a strictly wary attitude to him and his like until, feeling an irresistible call upon me, so to do, I left those pleasant food-full waters and set out for my long journey across the Northern Pacific. I say long to suit your meagre comprehension; to me its length was a mere matter of indifference, for the exercise of my powers were as spontaneous and natural to me as the gyrations of birds in the air above, there being no consciousness of effort.

I would I could recall for you the incidents of that trip from China to California. Tell you of the voyagers like myself whom I met and exchanged greetings with in the Middle sea, of the myriad wonders that to me became commonplaces. Make you understand the 


\section{Pride of Power}

all-compelling power that, implanted in me and in those I met with in all my journeyings, made us employ our vigour in the way we did, and fill ourselves with the sheer delight of clean, abounding life. Describe to you the splendour of the midnight sea, the brilliantly illuminated waters, lit beyond all man's imaginings, and yet ever assuring us that beyond our powers of investigation were splendours far greater. Never a hungry moment, never one instant when I felt that I ought never to have been, as I know you humans do feel ; ah ! how much I have lived! Once I measured my speed against a mighty steamship in company with many porpoises. I easily outstripped them all, easily swam round her as she did her best, and when under her bows crossing, in as rewarded for my magnificent exhibition of strength and endurance by just escaping a brutal downward thrust of a weapon with fine barbed points. One did plough a deep furrow in my side ; but I did not mind that; wounds far deeper and more serious are healed at sea, and the receiver of them cares not nor bears malicious remembrance of them.

In due time (what do I know of time divisions such as bind you ?) I arrived at Puget Sound. It was high summer, and those pellucid waters were full of fish. Never before had I tasted the joys of biting into the body of a twelve to twenty pound salmon, of chasing a school of immature salmon into an estuary, where I could devour them at my leisure. I spent here a perfectly satisfying holiday, daily adding to my girth and other powers. Then I thought I would go south, or, rather, the initial impulse was communicated to me by that outside force of which we know nothing, but that we all acknowledge its power, and I sidled southwards reluctantly. 


\section{Ig6 The Albacore}

That was a premonition of disaster, had I but known it, for on the second day of my arrival on the Californian coast I was lifting myself lazily, with a full stomach, to a passing squid, a tiny creature not worth my attention, when I felt a sharp pain shoot through my jaw and a slender yet annoying, pull at my head. In rage I started seaward, regarding not the sting among my teeth; furiously I wondered who had dared attempt this outrage upon me. I do not care to say how dire was the distress I felt when, owing to the skill of the man-thing in the boat, behind the rod and at the end of the line that had hooked me, I could not get free. I only record that from the rising to the setting of the sun that man fought with me, and was drawing me so near to his boat that I felt almost hopeless of ever seeing blue water again, when I made my supreme effort. I dived seaward at utmost power, and almost immediately knew that I was free. But I bore with me a souvenir of my encounter in the shape of a barbed piece of steel imbedded in my lower jaw, which galled me ierribly. It had struck through a piece of plated bone, and could not work out. Still, after awhile it ceased to annoy, and I grew quite unmindful of its presence, until at last, when it did drop out, I knew not of its going. Is it necessary for me to say that I left those inhospitable shores in haste? I had no idea that men would hunt for me in such a fashion, no prevision of any dangerbut I must not anticipate. Out on the blue, wide, free sea I bore, and, resuming the glad, free life of my deep-water fellows, soon forgot my perilous adventure.

Now, had I realised it, I was beginning a terrific journey without any such halt as I had before enjoyed in the cool recesses of the East Indian Archipelago. The need was laid upon me to go westward, ever 


\section{Homeward Bound}

westward and southward, for, although I did not know it, my God-given instinct forbade me attempting the passage of Cape Horn, where the cold would certainly have stricken me dead. But these things being hidden from me, I fared leisurely on my way, taking bright sea and gem-like clusters of islets in my way as they came, like a philosopher. Indeed, I felt myself one now. I had seen almost the whole world, and none of its wonders had any power to move me. Only, I did feel an intense longing for, a mighty drawing to, the waters of my birthplace, so very far away. I did not in the least know where that birthplace was, but what of that? As the magnet draws the needle, so I was being drawn, and though only dimly conscious of it, as quite content to be guided. Time did not matter -we do not reckon the hours in our beautiful home beneath the sea. We are content to fulfil the law of our being, without regard to how long or short a time it takes-in fact, for us, time has no meaning. We live in a timeless state, in what you call Eternity, except that we are so frail, so continually passing from one shape to another.

So gradually I worked my way round the watery world towards the Cape of Good Hope, quite unmolested by anything or anybody, but forgathering on my way with many of my congeners, all bound in the same direction. And the strange thing about all our journeyings was that none of us knew why we were goingwe only felt that we must go, and also were sure that we should arrive at our destination unless-but then we never anticipated any cessation of being, we just went on living our life with all our might. Gradually, surely, I worked my way round the Cape, wondering as much as we can wonder at the numbers of my fellows I fell in with. Having led quite a solitary life for so 


\section{I98 \\ The Albacore}

many months, it became almost irksome to me to meet so many of my kind at one time. And when I found the numbers of my friends daily increasing, I felt almost a panic fear lest the supply of food should fail us. How little, for all my experience, did I yet know of ocean's resources! Presently I found myself swimming in the van of quite a large school of huge Albacore, making steadily northward up that pleasant sea of the south-east trades towards the Line.

We overtook a ship-a great white-winged ship -whose crew never molested us, and whose passage through the quiet waters stirred up for us quite an abundance of savoury food, such as squid and flyingfish. But she proved a treacherous guide, a dangerous friend. We followed her docilely into St. Helena Bay, and when we got over the shock of her anchoring, played about her as we had done aforetime. Then the natives came with spears and hooks and slew amongst us to their hearts' content, as we basked in the sun or sought the shade of what we had grown to consider our great friend and protector. It was an awful massacre, the first I had ever seen of my own kind, although I suppose that my inroads upon the schools of skip-jack would be looked upon by those victims in the same light. But it may well be asked, why did we not by a few flashes of our tails speed seaward and downward, where nought of man's harmful devising could touch us to do us hurt? I do not know ; I can only record facts and say that at the onslaught of the fishermen we just rushed aimlessly about in the blood-stained water, as do the skip-jack or bonito when we suddenly make a raid upon them. Were I given to speculation upon any subject, I should suppose that it was a providential suspension of our usually acute faculties for the benefit of mankind, 


\section{A Great Slaying}

I99

who would otherwise have no chance whatever to obtain our flesh for food.

But when the slaying ceased, and the boats laden almost to sinking with dead Albacore had returned to harbour, our panic ceased also, and, closing up our scattered ranks, we resumed our journey northward. The grea \pm catch granted to the islanders at St. Helena really seemed to have made no perceptible difference to our numbers, which, it must be remembered, were continually being added to by recruits from all sides. So that when we reached Ascension, that lonely rock in the middle of the wide Atlantic, whose shelving sides beneath the sea swarm with all that an Albacore need use, we were an army of great fishes swimming in close order covering nearly a square mile, and in many places ten fathoms deep. Our descent upon Ascension must have caused an awful panic among its submarine population, all of whom, with the exception of some vast cuttle-fish that inveigled a few of our members, paid delicious tribute to us, satisfying our hungry needs, as far as they ever are satisfied, in a most enjoyable way.

To say that we swept the rock bases bare would be exaggeration, but we certainly did find on the second day of our visit that the juicy morsels which had been so plentiful were scarce and hard to come by. So we simultaneously moved off without any word of command, any leader, any directing impulse, save the one unerring instinct. And how fully sufficient it was! Just after departing, however, we suffered considerable diminution of our forces, a really noticeable lessening of our vast numbers, compared to which the slaying at St. Helena was not worth mention. We encountered a vast school of sperm whales whose mighty bodies lay end-on to our path, and all their 
cavernous jaws were wide agape. Down into those enticing interiors our people plunged eagerly, silently, without thought or, had they known it, hope of return. As I have already said, I knew those pleasant-looking but deadly entrances too well to be taken in by them; so carefully avoiding them I swam on, steadily on, through the black ranks of the monsters so busily entombing my companions by hundreds. That was all any of us needed to do, just to avoid the gaping throats, otherwise we were perfectly safe from molestation at the mouth of any whale that ever swam.

So we fared on, our diminution more than made up in a few hours by the recruits constantly closing in upon us from every side, and passed through those quiet waters between the Trades in very leisurely fashion. For they are very rich in the food we love, and we were all singularly voracious even for us. Instinct warned us that, where we were going, food would be far from plentiful, while duties of reproduction would require us to be in the very best of condition. So, in spite of the magnetism drawing us ever onward, we neglected no opportunities for feeding, and must surely, for a short time at least, have rendered the path taken by us through the Atlantic almost bare of food for the lower members of our family. But that I cannot positively say; I never missed food. Although I was always hungry, there always happened to be food near my mouth, and the way I continued to put on girth and strength was truly wonderful.

At last we drew near the Straits of Gibraltar, millions of us in a compact body, swimming steadily forward now, without thought of eating, in a triangle some miles in area. No human being knew of our coming, because we swam at a depth of ten fathoms or thereabouts, nor ever rose to the surface. Our 


\section{Our Welcome Home 201}

goal nearly gained, the drawing power over us that had so mysteriously brought us from the furthermost ends of the earth seemed to have suddenly increased its force, accelerated our speed, and overcome our desire for food. So we swept up the centre of the great Middle sea as far as Pantellaria, when, as if actuated by a sudden impulse, the mighty wedge of steadily swimming fish parted in two irregular portions, each portion immediately closing up its disarranged figure into triangular shape again. The lesser triangle kept on eastward, bearing over towards the African coast, but the larger one swerved sharply to the northward for the Sicilian shores.

Again, I cannot tell why no instinct warned us of our awful danger ; but I swam, being one of the largest of our giant members, at the head of this great body until we came right up to the rock bases of Sicily, and splitting up into numerous small bodies swarmed along the shores of Italy and Sicily, and through the Straits of Messina. All had been prepared for our visit, although it had been quite unheralded by any advanced guards, the humans on land depending entirely upon our faithfulness and constant adherence to our regular customs. In places to which we had always come hitherto, that is, our ancestors, great corrals of netting had been prepared with long passages into which we must swarm to get to the regular spawning-grounds. And many boats full of men lay quietly waiting to harass, with shouting and splashing, any idea of returning with a rush that we might have. In this way an enormous number were captured and slain; for once within these barriers of netting, and the way out again barred, we were driven farther and farther into shallower and narrower places, where savage men armed with spears slaughtered our helpless 


\section{The Albacore}

members to their full content. And we had come all round the world for this! The terrible massacre was proceeding at many places with the utmost fury, and in mid-sea queerly rigged feluccas were luring individuals with huge rods and stout lines; an easy task, for we were all so ravenous that a fluttering piece of rag was at once mistaken for a flying-fish or squid, and eagerly snapped at.

Oh, it was a black and awful time for us, and yet in spite of the elaborate preparations made everywhere for our capture, and of our utter want of forethought or attempt to avoid those deadly shores, it is certain that only the mere fringes of our great host were captured. But those of us who escaped could claim no credit for superior wisdom or greater skill in avoiding danger. We survived, because for one thing the sea is so wide and so deep, even the Mediterranean, that man is closely limited in his powers of destruction, and because, there being so many of us, all could not get inshore at once to where the traps were laid for us. Also, the majority of us were bound farther eastward to the $\mathbb{E}$ gean, to those quiet spawning-beds where I was born, and where in due time I arrived again after visiting all the tropical and temperate parts of the oceans of the world down to a depth of one hundred fathoms.

Then commenced the all-important business of our visit. The females in long ranks settled down upon the pleasant smooth patches of sandy sea-floor in all the sheltered nooks so well remembered, and deposited with utmost care and regularity their burdens of pearly eggs in long, level rows. Behind them swam the males, steadily, methodically distributing milt and spreading it evenly with quiet wavings of broad tails, at the same time keeping a wary eye open for 


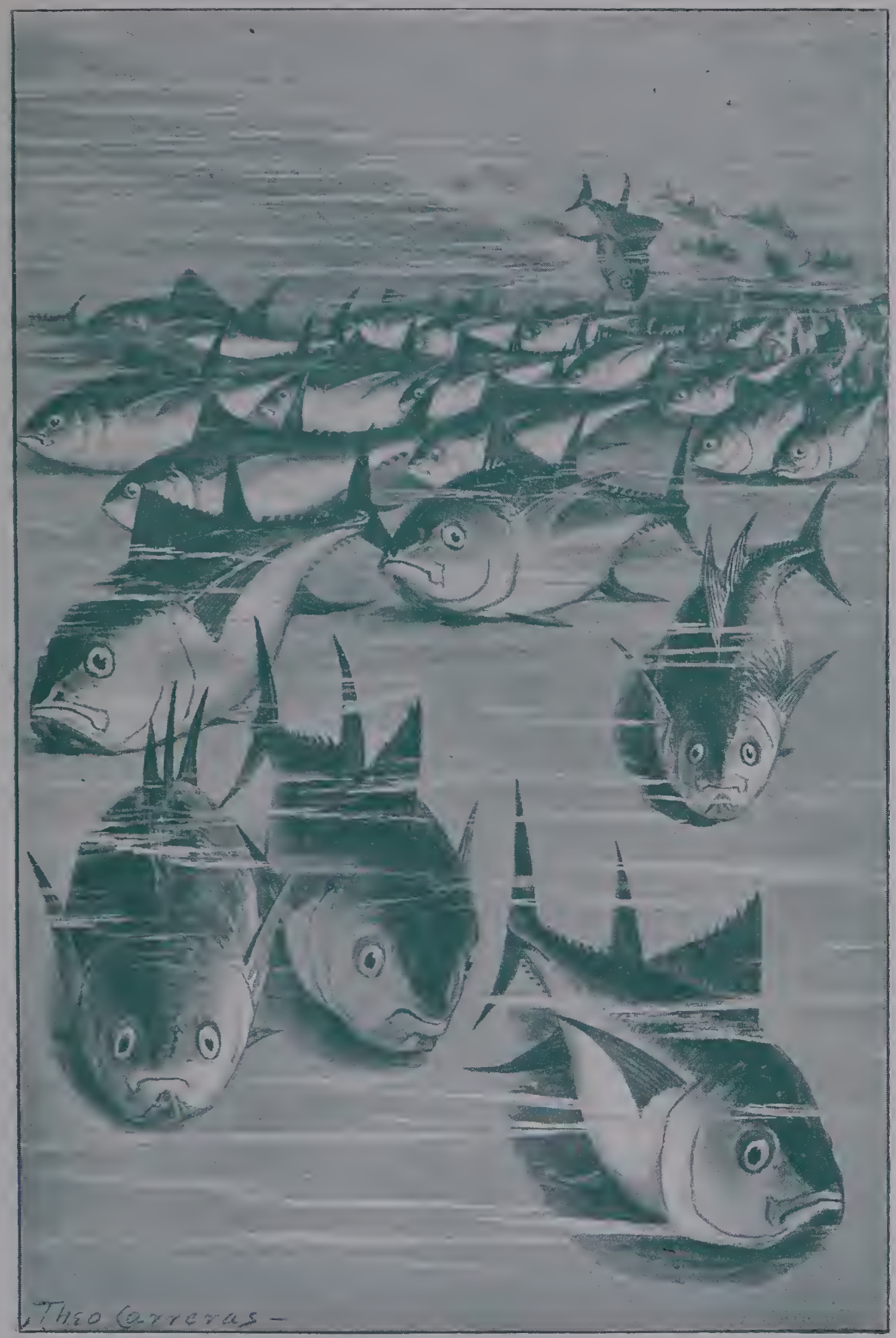

BREEDING PLACE OF THE ALBACORE.

[To face p. 202. 



\section{Unnatural Appetites}

the possible advent of marauders. But no sooner was the important part of the business accomplished than our hunger often tempted us to devour this treasure we had come so far to deposit, and I here at once avow that the greatest enemies of our own ova were ourselves. Why we did not render the race extinct I know not, unless that in many, nay, most cases, the eggs had been so cunningly hidden that we could not find them ourselves. Nor do I know how long the business lasted. Only one day, impelled by the fiercest pangs of hunger, and by an uncontrollable desire to get out where food was plentiful, I started westward at a furious rate of speed, and escaping every lure, soon found myself once more in the Atlantic, recommencing my world-wide wanderings. 


\section{CHAPTER XVI}

\section{THE BONITO}

NE of the first of the deep-sea people to greet the young deep-water sailor after the porpoise, is the gay, chubby, and brilliant fish whose name stands at the head of this chapter. It was thus called by the early Spanish voyagers, the word meaning 'beautiful.' But I do not think they thus named it for its colours or its grace of movement, since in both it is greatly the inferior of the Coryphana. Rather I think it was so called from its edible qualities, combined with its friendliness and amenability to capture. It is a far more frequently seen fish than either the albacore or dolphin, and is also much more sociable than either of them. Moreover, it is gregarious in its habits, and swims in very large companies, so large, in fact, that I have often in light winds, when the sea has been comparatively smooth, been unable to look in any direction without seeing Bonito busily leaping about after their terrified prey.

It is certainly a mackerel, a poor relation, so to speak, of the albacore, which it greatly resembles, though with several important differences. For instance, the brilliant gold colour and imposing size of the albacore's fins are greatly modified in the case of the Bonito, as are also the curious bony processes along the medial line near the tail. Its colour, too, a dark blue, is not so pronounced, so transparently 
handsome, as is that of the albacore. In fact, it belongs to the rank and file of the sea, a common, every-day sort of a deep-sea denizen, while the albacore and dolphin are rather the aristocratic leaders of sea society, after the whale tribe. This commonness of character, coupled with what it is only a slight stretch of language to call affability of demeanour, is what has endeared the Bonito to sailors generally, although alas, from the same cause as before noted, i.e. the decay of the sailing vessel, there are many sailors afloat who have never seen, and probably never will see, one.

There is another, and still more important reason why the Bonito is the sailors' best-loved fish-the ease with which he may be caught. The handling of the albacore from a ship's bowsprit is a task demanding much more powerful tackle and strength of arm than any ordinary man can give to it ; in fact, it is very seldom that one takes a sailor's hook and is afterwards secured. During all my voyages I have only seen four actually brought on deck, but I do not remember how many, only that it was a very large number, that I have seen hooked and get away.

Once while fishing for Bonito from the flying jib-boom end (my favourite place) I was vigorously flicking my lure, when a dark shadow shot upward from beneath the ship and sprang into the air, revealed as a superb albacore. I frantically jerked my line upward as I saw him coming, but in vain; he seized my bait in mid-air and got well hooked. He was so heavy that I could only lift him with both hands to the line at once, yet I succeeded in bringing him within six feet of my perch. Then the long-suffering line parted and he fell back into the foaming head wave with a stupendous splash; and I realised with a shudder from what I had escaped, for how could I, on 
that giddy eminence, have dealt with such a monster ? He would certainly have paralysed my grip with his struggles and shaken me off the boom. The dolphin, too, is a fish that is seldom caught, not because it will not take a hook voraciously when the circumstances are favourable to its being deceived, but because it is not so sociable in its instincts as is the Bonito, and consequently does not give the sailor so many opportunities of becoming closely associated with it.

But the Bonito is essentially the sailor's friend. In a slow-moving ship with a light breeze, I have known a school of Bonito keep company with the vessel for three days at a time. Apparently they took it in turns to escort her by proceeding steadily in orderly rows under and around the bows, while the rest gambolled about, hunting ahead, abeam and astern. And I have often seen three lines going among them at once, fish after fish taking the upward journey, until two or three dozen have been caught, and never a sign of alarm among those below, unless one of the hooked ones got off and fell back among his fellows with a loud splash, and with blood streaming from his gills. Then indeed there would be an instant disappearance of the whole school, only sometimes a quick eye could catch a departing leap or two some distance away. That, of course, was due to the smell of blood, or whatever sense it is in fish which takes the place of smell, apprehending that there was blood about. Any fish thus wounded among his fellows in the deep sea has no suffering-he is torn in pieces and devoured instantly. And in none was this more noticeable than in the sharks, for whenever one met his death by the blow of a blubber spade, which was about every five minutes, while we were cutting in the whale, his companions fell upon him and tore him 


\section{A Life of Peril}

in fragments before he had time to sink, and instantly returned to their furious occupation of tearing at the whale.

In considering the life of the Bonito, we must remember that we are descending the size scale, and that consequently the number of his enemies appreciably increase. The largest Bonito I ever saw scaled only twenty-eight pounds, and I feel sure that he was a great exception to the general rule, the average size being eight or ten pounds. Owing to their habit of swimming in large schools, and of crowding together as if for mutual protection, when instinct warns them that enemies are about, they fall a comparatively easy prey to such voracious enemies as the grampus, the albacore, and the sword-fish (Xiphias), while, of course, they themselves prey quite as furiously upon the younger members of their own family. But they must be an amazingly prolific fish, judging from the enormous schools met with and the ease with which they may be captured by their enemies.

As to their place of origin, there is perhaps more mystery about that than about any other of the pelagic fish. Whether they imitate their giant relative, the albacore, and make periodical visits to comparatively shallow waters in order to spawn, or as the dolphin do, deposit their ova upon and among floating masses of sea-weed, is a point not easily settled. But two things are certain, and they are, that, like the dolphin, the Bonito is never seen near land except that be very abrupt in its rise from the sea-bed, like St. Helena, and being essentially a surface-fish frequenting the deepest ocean areas, he cannot go to the bottom to spawn. And when we have stated that, we have exhausted our knowledge of this creature's family habits.

I have caught them in the North and South Atlantic, 
in the Indian Ocean, in the North and South Pacific Ocean, nearly always remote from any land, and I have many times noticed the female roe bursting ripe. But where they had proposed to go to spawn was always a problem far beyond my ken, or ability to elucidate. Indeed, there is a great deal to be done for oceanic ichthyology, in spite of the wonderful work of the American Government expedition in that direction. It has accomplished an immense amount of valuable work, but one feels that only the fringe of the subject has yet been touched. The Natural History of the sea calls for the unpaid work of enthusiastic amateurs like the Prince of Monaco, who, with great wealth at his disposal, refuses to waste his life in the idiotic dissipations of European capitals, choosing rather the absorbingly interesting (and much less expensive) pursuit of studying the deep-sea fauna in his beautiful yacht, the 'Princess Alice.'

Even the study of so essentially a surface-fish as the Bonito is attended by many apparently insurmountable difficulties; what then must be the case with fish who rarely, if ever, rise to within a hundred fathoms of the sea-surface of their own accord ? And then one of the greatest incentives to close investigation of the habits of any creature is entirely absent in the case of deep-sea fish, i.e. that of commercial gain. While there are many of them, and especially the more accessible ones, fairly good eating, they flourish remote from markets of any kind, and they are never likely to be taken in any quantity. Moreover, they take far too kindly to salt, as do indeed all the mackerel tribe. American salted mackerel is a thing of horror to most of us who like salt in moderation. To my mind it tastes like solidified brine, with a flavour of fish. And no amount of soaking or parboiling seems 


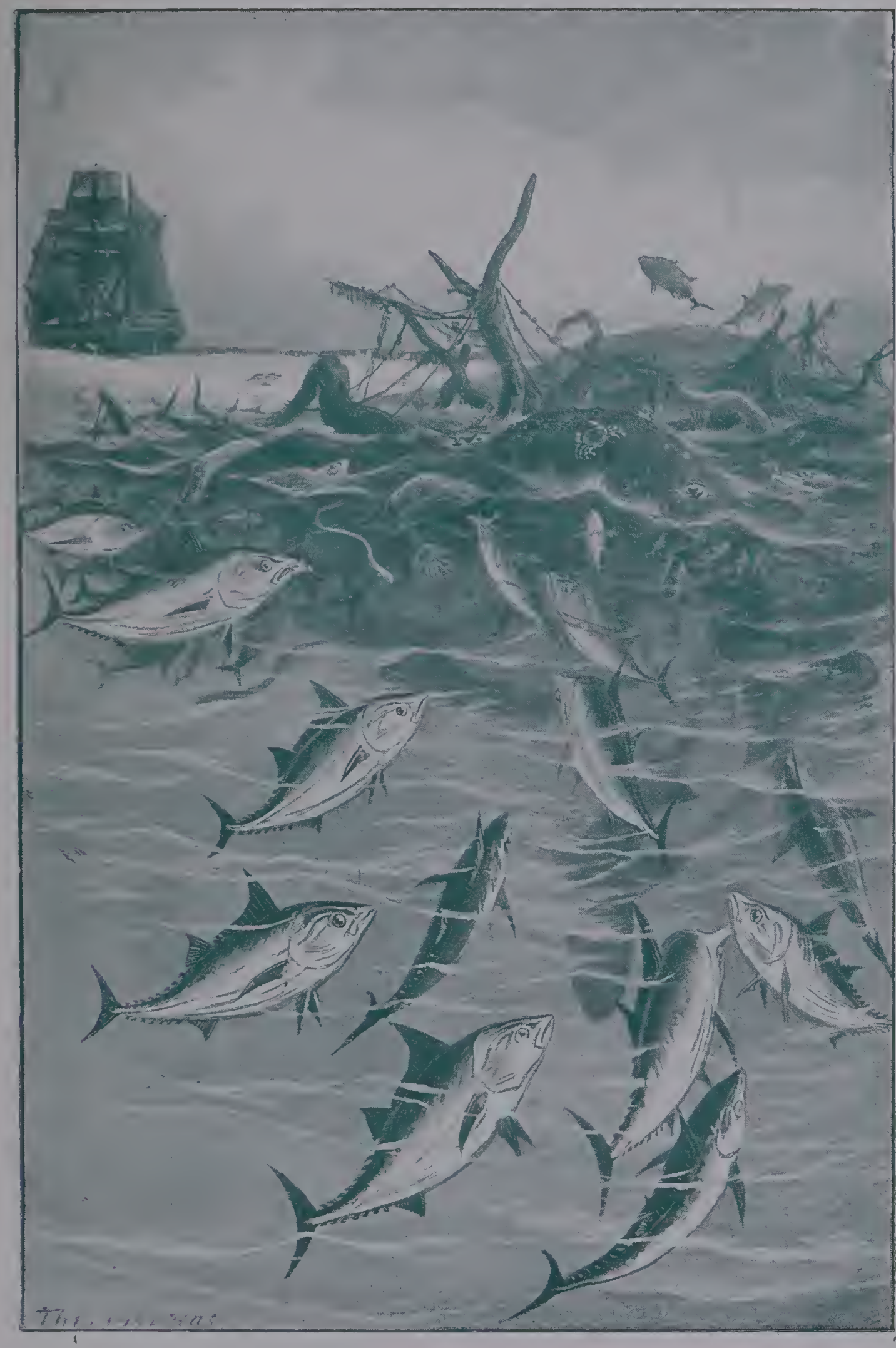

A SCHOOL OF BONITO.

[To face $p .208$. 



\section{The Fish that Won't Keep 209}

capable of modifying to any appreciable extent its malignant salinity.

The Bonito is, if anything, still worse. Mournfully do I remember how, having a field day among Bonito just on the northern side of the Equator in the Atlantic, homeward bound in a very slow ship, the steward proposed that, as the weather was quite cool, he should be allowed to salt about thirty fine fish, or in the neighbourhood of four hundred pounds weight, so that our miserable rations of putrid beef and pork might be eked out in a little more Christian fashion. The idea was jumped at, and I, having considerable experience in cleaning fish, spent my watch below eviscerating and boning the fish ready for the pickle.

The job was eminently successful, not a trace of taint appearing in the pickled fish. In high glee we welcomed the first mess of salted Bonito, but alas, we were most cruelly disappointed. Hungry sailors can eat almost anything, but that terrible fish was beyond us. It scarified the mouth as the eating of pure salt would do, all trace of fish as far as flavour was concerned seemed to have fled, and yet it had been steeped all night and parboiled in two waters. Various schemes were tried, such as soaking it in vinegar, drying the salt out of it in the sun (when it became like a piece of alabaster), but all to no purpose. And most tantalising of all, it retained a singularly appetising smell. The whole mass was dumped overboard, much to the gratification, no doubt, of a school of sharks, which was following us. But even they, I should think, must have wondered what the new and strange food was which they had gulped down so readily, if, as is somewhat doubtful, the shark has any discrimination in matters of taste at all. 
The flesh of the tunny or albacore, which is most closely akin to that of the Bonito, is treated very sparingly with salt, and is preserved by boiling it in oil and sealing it up in tins, which makes it a delicacy that keeps for an indefinite period. No doubt if the Bonito could be caught in easily accessible positions, it could be manipulated in the same sensible way, and might become an article of considerable commercial value. But of that there is not the slightest prospect, so that the Bonito will doubtless be left to pursue his jovial way in peace.

Moreover, there is no blinking the fact that, in spite of the bitter cry of starving multitudes on shore, the incalculable wealth of the sea in food largely goes a-begging. Only let the fishermen be a little more than ordinarily successful, and immediately our souls are saddened by reading of many tons of succulent food being carted away for manure, or left upon the shore to poison the pure air with putrid exhalations. Nay, more, there are not wanting many grave and specific accusations levelled at market magnates, who for fear of a lowering in price, deliberately prevent the distribution of this excellent food, thereby committing the triple crime of robbing the fishermen of their due, keeping from the poor their food, and wasting the precious gifts of God. It is a terribly sad thing to know, and sadder still perhaps to be unable to suggest an effective cure for such a gigantic evil. And if this be the case with the harvest of the sea so easily garnered near shore, how much more is there the greatest unlikelihood of any new fishery being opened up farther afield, and of fish that will not keep ?

Bonito are found wherever albacore and dolphin are, only more so. For instance, they appear to be more enterprising, readier to respond to the slightest 


\section{Deep-Sea Swarms}

rise in the temperature of the water outside their usual limits, so that I have caught them north of the forty degree line and almost as far south as the Cape of Good Hope. In the great, wide areas of loneliness to be found in the Pacific and Indian Oceans, they are, as might be expected from their habits, very plentiful, but I think that the largest number of them I have ever seen at one time was in the South Atlantic, well east of St. Helena and Ascension, in that vast and almost unvisited stretch of abysmal ocean known to geographers as the 'West African Basin,' where the depth varies from sixteen to eighteen thousand feet, and the sea literally swarms with life.

On the eastern verge of this immense depression the south-east Trades, affected by the proximity of the African land, fail and falter, falling almost to a calm. Then the belated ship, alone in the centre of a vast expanse, becomes a point of interest to the wandering population of the sea who visit her and exhibit themselves in many a curious evolution.

Here, where no sailing-ship ever ought to be found, I have seen, as mentioned in the opening lines of this chapter, the Bonito so plentiful that I was unable to look in any given direction without being aware of thousands of them leaping after their ever-abundant food. And at night, when the sea was lit up by its natural fires of phosphorescence, the scene was ineffably grand, the mild effulgence being stirred continually into bright mazy patterns of glowing light, while the happy fish, apparently contemptuous of rest, came and went on their ceaseless errands.

Here, too, we witnessed a scene that impressed itself upon the minds of everybody on board, as being past all their experience. It was at high noon, with but a light upper air stirring the sails, and wafting 
the old brig along so gently over the glassy sea, which was untouched by the descent of the slightest air, that sitting out upon the jib-boom end one could look down into the translucent depths as through a pane of glass, and watch the gambols of the sea-creatures at a depth of several fathoms.

So quiet had been the weather for several days, and so little did the passing of the ship disturb the sea-folk that there was almost as great a variety around us, ranging from the tiny silvery fry playing hide and seek among the deadly fringes of the mushroom-like Medusae, to the mighty albacore, as one would have expected to see in the most representative aquarium. Only that here there was no suggestion of bounds to that vast play and feeding ground. Suddenly there came from the fore-to'-gallant yard a cry of 'breakers ahead, sir.'

'What's that?' sharply queried the 'old man.'

The man repeated his information.

'Nonsense!' angrily snapped the skipper, 'the nearest land ain't less than three hundred mile off, and there ain't any bottom here less than three thousand fathom. Pop up aloft, Mr. Jones (to the mate) an' see what that galoot's a-gittin off his chest.'

Up went the mate on the instant, taking the glasses with him. Presently he shouted: 'I can't make it out, sir; it looks just like a line of breakers extendin' from west to east, as far as I can see with the glasses. But it ain't breakers, 'cause I can see nothin' but just the single line, and beyond it the water's smooth as 'tis here. Looks like a tide rip, only I never see one so monstrous as that.'

By this time the phenomenon, whatever it was, had arrived within a mile of us, and was apparently travelling at the rate of about six miles an hour. A 


\section{A Mysterious Concourse 213}

deep roaring as of the distant voice of many waters was heard, gradually growing in volume. All hands came uncalled on deck, and watched with considerable anxiety the approach of this uncanny roll of white; it drew nearer and nearer, until presently we passed through it with only a very slight motion of the vessel, for by an optical illusion it appeared a great deal higher than it really was. The width of the line of foam was about sixty feet, and in it could be seen an amazing variety of sea debris, while it also seemed to be alive with fish of all kinds.

But the chief wonder was a few cables' length behind the strange line of white. It proved, on nearer inspection, to be a mass of land vegetation consisting of several huge trees inextricably entangled by their branches and snake-like convolutions of giant creepers. It looked like a floating island, but -all alive. So wonderful did it appear, so full of movement, that a boat was got out in order that the skipper might go and examine it, and while I live I shall never forget the amazing sight it presented upon a close view.

Long before we got to it, the boat's way was impeded by the vast numbers of Bonito converging upon it and making the sea appear as thick with fish as it does in the middle of a herring shoal. We pressed on, however, noticing how every stroke of the oars was followed by a crimson stain melting into brown, until we reached the central mass. It was so densely crowded with fish, large and small, with sea-snakes, with crabs, with creatures for which one could find no name, that it seemed like one vast mass of living, writhing forms. At a distance one could see the shapes of the trees and their interlocked branches; alongside all seemed alive. 
Now there was not the slightest suggestion of danger; for the sharks, of which of course there were many, had such abundance of easily gotten food about them that even had one of us fallen overboard, I do not believe we should have been molested at all. But in the presence of that seething mass of life, all self-subsisting, ever devouring, ever unsatisfied and inexhaustible, a positive sense of fear came over us all, and when the skipper said: 'Stern, boys, and let's get out o' this, I don't like it,' we felt that he had aptly voiced our own sentiments. So we returned to the ship; feeling quite relieved to get on board again, and place something more substantial between us and those hungry hordes than the thin shell of a boat. I know it was foolish, but that is how we all felt.

One peculiarity of the Bonito I must notice with some diffidence, because I know that I shall find myself in opposition to naturalists generally. It is a commonplace that a fish is a cold-blooded animal, and it is, generally speaking, true. But the Bonito has blood as warm as our own, and I know it experimentally. The first Bonito I ever caught was when I was barely fourteen, and small for my age. I bestrode the flying$\mathrm{jib}$ and locked my legs inside the jib-guys and round the boom-end. Still the stout, slippery, chubby form of the fish (he was about fifteen pounds weight), aided by his extraordinary vibrations, made it impossible for me to hold him by cuddling him tightly to my bosom. So in a fit of desperation I jammed my fingers into his gills, and must, I suppose, have ruptured his heart, which is very close to his gills, for immediately a miniature torrent of hot blood flowed all over me, much of it running down my bare chest inside of my shirt, which as usual, had no buttons on the front. Then, finding my strength fast going, I 


\section{Troubles of an Observer 2I5}

bundled my prize up in the folds of the flying-jib, which was lying loosely furled upon the boom. The state of that jib when hoisted procured me a painful interview with the bos'un, which I do not care to recall, and my positive assertion that the fish's blood was warm obtained me another hiding from the sailmaker, for what he called contradicting.

Singularly enough, such frequent disasters at these, consequent upon my stating what I had discovered for myself, while they naturally made me very reticent in the presence of my elders on all debatable subjects, have had the effect of making me loth to state my experiences to anybody in a superior or authoritative position-until the last few years, when, tired of feeling so cowardly, I ventured to maintain opinions based upon practical knowledge against ideas builded upon theory. After that unpleasant day, I always noticed how warm the blood of a Bonito was, but have only once before stated it in print, when I was promptly taken to task by an old and dear friend, a shipmaster, who, while admitting that he had no recollection of ever feeling a Bonito's blood in his life, was sure that it could not be warm, as the Bonito was undoubtedly a fish, and all fish were cold-blooded.

The Bonito is peculiarly liable to the attentions of parasites, both internal and external. I do not, therefore, mean to hint that other fish have none, only I have not been able to see them, whereas in dissecting a Bonito it is impossible to avoid noticing them. There are minute hangers on, something like tiny limpets, in such snug places as behind the pectoral fins, or between the ventrals, or on the 'run' of the fish, where the body slopes away rapidly from its central fulness to the fine lines of the tail. The presence of these may account for the apparently 
aimless perpendicular leapings of the fish, quite different from his dash into the air after a flying-fish or squid. It is easy to imagine that the irritation caused by these vermin must sometimes become well-nigh intolerable. And they cling so tightly that I have never been able to tear one off the freshly caught fish, without bringing a portion of skin with it.

Inside the mouth, and often nestling among the branchiae of the gills, will be found one or more white crustaceans, much like an exaggerated wood-louse, but not so flexible in the body, being incapable of rolling themselves up in a ball! They have eight or ten hooked legs, by means of which they attach themselves firmly to the mouth, or throat, or gills of their host, and thenceforward lead a placid, well-fed, and uneventful existence at their host's expense, being apparently quite exempt from the almost universal law of eating and being eaten in turn. I do not see what can ever disturb them except the death of the fish. When that happens they release their hold and crawl out of the mouth or gill-openings, seeking, I suppose, a fresh host, able to provide for their needs, having doubtless realised that no more board and lodging is to be expected from their late benefactor. In like manner does the tenacious clutch of the outside parasite become relaxed, and he falls off when the last quiver of the flesh has ceased, and the fish is dead.

A much more unpleasant form of parasite is one which burrows into the muscular tissue, sometimes in such numbers as to make it impossible to eat the meat, unless the eater be something of a savage, either from hunger, or place of origin. It is just a fat white maggot, not so well formed as those seen in fly-blown meat, but a clumsy grub, which slowly eats its contented way through the fish's muscles, leaving behind 


\section{The Involuntary Host}

it a tube to show how it has bored its way to where it is found. I have also found several curious living things in the Bonito's maw, but have never been able to determine whether they were regular lodgers or just visitors in the ordinary course, but being possessed of greater vitality than the other creatures upon which the fish has fed, had not yet succumbed and become subject to the digestive process.

A very instructive study is that of the contents of the stomachs of deep-sea fish, for they are by no means (as might be supposed) composed of merely flying-fish and squid. There are often to be found small fish of shape quite unknown to us hitherto, and certainly never seen by sailors. Fish, we must assume, that live within the eater's range of depth, but never come to the surface voluntarily.

Of the many services rendered by Bonito to shipwrecked people at almost the last gasp for want of food, there is no need to speak; it will be at once understood that so plentiful, sociable, and easily allured a fish as the Bonito, must often have furnished a meal to people who would otherwise have starved. And no one, who has not been driven to it, can know how nice a Bonito collop, cut off the quivering body and laid upon the almost scorching wood in the full blaze of the sun, until it curls up and turns quite black, can taste. Only of course, it presupposes strong teeth and wolfish hunger.

There is a sort of poor relation to the Bonito, yet resembling much more closely the great albacore in the contour of its body and the arrangement of its fins, to which sailors have given the trivial name of 'Skip-jack.' Scientifically it is termed Thynnus sarda, and has even been found as far north as the mouth of the Esk. Only one specimen though. It 


\section{8 \\ The Bonito}

is an elegant little fish, never growing heavier than about five pounds, and exceedingly succulent as to its flesh, which is much superior to either that of bonito or albacore. It is not at all unlike the bluefish of the American coast, and I think its flesh is superior to that, highly as the latter seems to be esteemed in American restaurants.

Its usual range of habitat is, I should say, coextensive with that of the bonito, but being somewhat capricious in its appearance it is not nearly so often seen. It has earned its trivial name by its peculiar habit of doing continually what the bonito only does occasionally, that is, making short vertical leaps into the air for no apparent reason, except perhaps joie de vivre. It is a pretty and at the same time a peculiar sight to see a large school of Skip-jack all busily springing out of water, as if their very existence depended upon their doing it rapidly and regularly. They feed on the same food as do the bonito, but I have no doubt that now and then some of their smaller members fall victims to the hunger of the larger bonito. The Skip-jack and the bonito do not associate, they keep well clear of each other, as do all the different varieties I have hitherto named, unless one is chasing the other for a meal.

They are by no means beloved by sailors, for the simple reason that unconsciously they are very tantalising. Few things are more annoying to a halffamished crew than to see, on some delightfully quiet afternoon, the smiling surface of the sea dotted all over with circles caused by the upspringing of thousands of succulent fish, not one of whom will come near enough to the ship to be tempted, or if he did would be persuaded into the belief that a bit of white rag was a flying-fish or squid. 


\section{The Unsociable Skip-jack 2 I9}

Sociability, in the sense that most of the pelagic deep-sea fish have it, they do not possess, and although large numbers of them are often seen at one time they always preserve a certain individuality, an aloofness from each other, like that of the dolphin. As to accompanying a ship in the same way that dolphin, albacore, and bonito will do, in varying degrees of closeness of course, that will they never. And yet they may-who knows-derive some sort of satisfaction from being, as it were, within hail of her. They are, more than any of the true pelagic fish, independent vagabonds of the sea, roaming each for himself whithersoever they list, and keeping their family haunts enwrapped in deepest mystery.

I remember with great satisfaction, two occasions on which, by the purest accident, I succeeded in catching Skip-jack, and subsequently examining them closely. I may say in passing, that they were the only Skip-jack I ever did see caught, and must admit that the capture was almost purely accidental. I had been fishing for bonito almost unsuccessfully, having only caught one, and the sudden tropical twilight fell before I was aware of it. But the evening was so lovely, the dying tints of the sunset so exquisitely tender, that I lingered on my quiet perch, loth to leave the contemplation of so much peaceful beauty. The line hung down almost straight, the bait just clear of the water, and occasionally I jerked it mechanically, my thoughts far away. Suddenly I felt a tug at it, and a weight upon it. Instantly called to present realities, I hauled up swiftly, to find a Skip-jack upon the hook, a fine specimen of about four and a half pounds, at which I was mightily astonished, as were my shipmates when I took him into the forecastle to show them.

The other occasion was at the front end of the 
day, as a French chum of mine used to term the dawn. I had been watching some stripes of light in the water alongside and ahead before daybreak, and determined that $I$ would put in the time between daybreak and 'turn-to,' six o'clock, seeing whether I could not invite one of the fish causing them, to breakfast with me. So, hastily swallowing my coffee, I seized my line and ran out to the flying-boom end, where I started to unroll just as the first crimson streamers in the sky began to be reflected in the darkling bosom of the deep. The moment my bait touched the water it was seized, and by another Skip-jack, much to my delight. But though I stayed till the last minute possible before 'turn-to' and forfeited my well-beloved smoke, never another came near enough for me to see him, much less to be enticed on to my hook. So I feel sure that in both cases my capture was due to pure accident, and that ordinarily the Skip-jack does not come close enough to a ship to be caught, or if he does, fights shy of any lure the fisherman may dangle over his head. 


\section{CHAPTER XVII}

\section{THE FLYING-FISH}

THE subject of this chapter is undoubtedly one of the most interesting in the long list of the great fauna of the sea. It has been the occasion for much heated discussion, which seems to be never ending; so-called authorities never appear able to agree upon the much vexed question of leap or flight. Quite as much nonsense has been talked about the Flying-fish as about the whale, and that also by people whose position in the natural history world imperatively demanded of them accurate information. Moreover, there has been more sympathy wasted upon the Flying-fish than upon any other sea creature. Its hard lot is bewailed because that, fleeing from its many enemies in the sea and soaring into the air, it is there seized by hovering birds, who doubtless regard its habit of flight as one that might most advantageously be followed by all the other small fish in the sea.

Now in what follows, as in almost all I have already written, I wish it to be clearly understood that only personal observation has been used as a basis for the remarks made, and consequently I am fully prepared for much contradiction. As a sample of the kind of thing all first-hand observers of little-known creatures must expect, I quote an experience of mine six years ago. I had written an article for a popular magazine, 
in which I casually alluded to the minor fact wellknown to all deep-water sailors, of the small cuttlefish or Loligo leaping high enough to be carried on board during rough weather, and in consequence often being found upon a vessel's decks. Shortly afterwards the editor forwarded me a letter from a gentleman, who stated that, although not a sailor, he had been round the world in sailing ships six or seven times, that he had never heard of the 'leaping' squid, and that it was perfectly ridiculous to say that such a clumsy creature as a cuttle-fish could leap on board a vessel. Consequently it was obvious that I was knowingly making an extraordinarily idiotic misstatement, etc. To which I replied (to the editor only) that the matter was one that could be tested any day by asking the first half dozen sailors met with at Green's Home, or any similar place, and that it being so well-known a fact to all seafarers, I did not think it worth while to answer the gentleman's letter.

But in the case of the Flying-fish I readily admit that an observer may have an honest opinion based upon casual observation, or misconstruction of terms. The difference between leaping and flying may be narrowed down until some sort of an agreement be possible, and yet neither party feel that they have been worsted in the field of argument. However, I must bring the Flying-fish himself forward. As in the case of several other deep-sea fish, naturalists have been gradually compelled to treat minor differences in individuals as accidental, and not as constituting differing species, until at last they have most sensibly reduced the Flying-fish family (Exocetus) to two species : $E$. volitans and $E$. nigricans.

The first named, and the smaller of the two, has the 
same amazing range of ocean as the Bonito, and is affected in precisely the same way by warm seasons, which induce it to venture farther north or south than it normally does, according to the time of the year. Its limit of size is about twelve inches in length by fuur inches in circumference at the thickest parts of the body. In shape it is exceedingly like a grey mullet, especially as regards the head; the body is perhaps a thought squarer than a mullet's, more like that of a gar-fish. In colour it is blue on the head and back, silvery on the abdomen, and it is covered with scales like a mullet or a herring. And herein lies one of its great claims to our notice-that almost alone among the pelagic deep-sea fish, it has not the slightest connection with the great mackerel family, being indeed much more allied to the denizens of shallow seas in its general characteristics, with one exception, and that is, its power of flight.

With the exception of the pectorals there is nothing remarkable in the fins of the Flying-fish except that the lower lobe of the tail is half as long again as the upper. But the pectoral fins, or rather wings, are nearly as long as the fish, and spread at their widest to full three inches. When the fish is in the water they fold with great neatness into the side of the body, which at the thickest part is slightly grooved to receive them. When the impulse comes upon the fish to fly, they spring into the air in a diagonal direction, their wings spreading with a flash as they leave the water, and vibrating with such rapidity that the eye cannot follow their movements, except to note that they are vibrating.

Now it is obvious that if this mancuvre of the fish were a leap, its direction, either vertically or horizontally, could not change, except that its trajectory 


\subsection{The Flying-fish}

would be more or less flattened according to the distance leaped. That much, I think, will be admitted. But if we see the fish leave the water, pursued, say, by an albacore, five hundred yards on the starboard side of the ship, and heading towards her, perceiving the great obstacle in its way, change its course to one at right angles to its original direction, we ought to assume that it is flying. Especially if, as constantly happens, it rises at the same time twenty feet or more in the air, and crossing the bows turns again sharply in a new direction.

Nor is this all, for I have repeatedly seen a Flyingfish, after changing its course three or four times and its elevation more frequently than that, after having flown at least a thousand yards, be about to drop, apparently exhausted, into the sea. But at that moment the gaping jaws of one of its enemies has protruded from the water, and it has shot vertically into the air again and sped away in yet another new direction. I am absolutely convinced that the only thing that compels the Exocetus to cease its flight is the drying of its wing membranes, when, of course, the vibration would split them to shreds. This, of course, does limit the aerial evolutions of the Flyingfish; but I have repeatedly seen it fly in varying directions for over a mile without once touching the water.

Now the Exocetus does not fly for pleasure. Whenever it leaves the water it is in a state of alarm, it is seeking safety from some of its numberless enemies, or it is disturbed by the passing near it of a ship's keel. There are few prettier sights to be seen at sea than is visible when, on a fairly calm night, with the smooth water highly phosphorescent, a school of Flying-fish are disturbed. Like a galaxy of meteors they may 


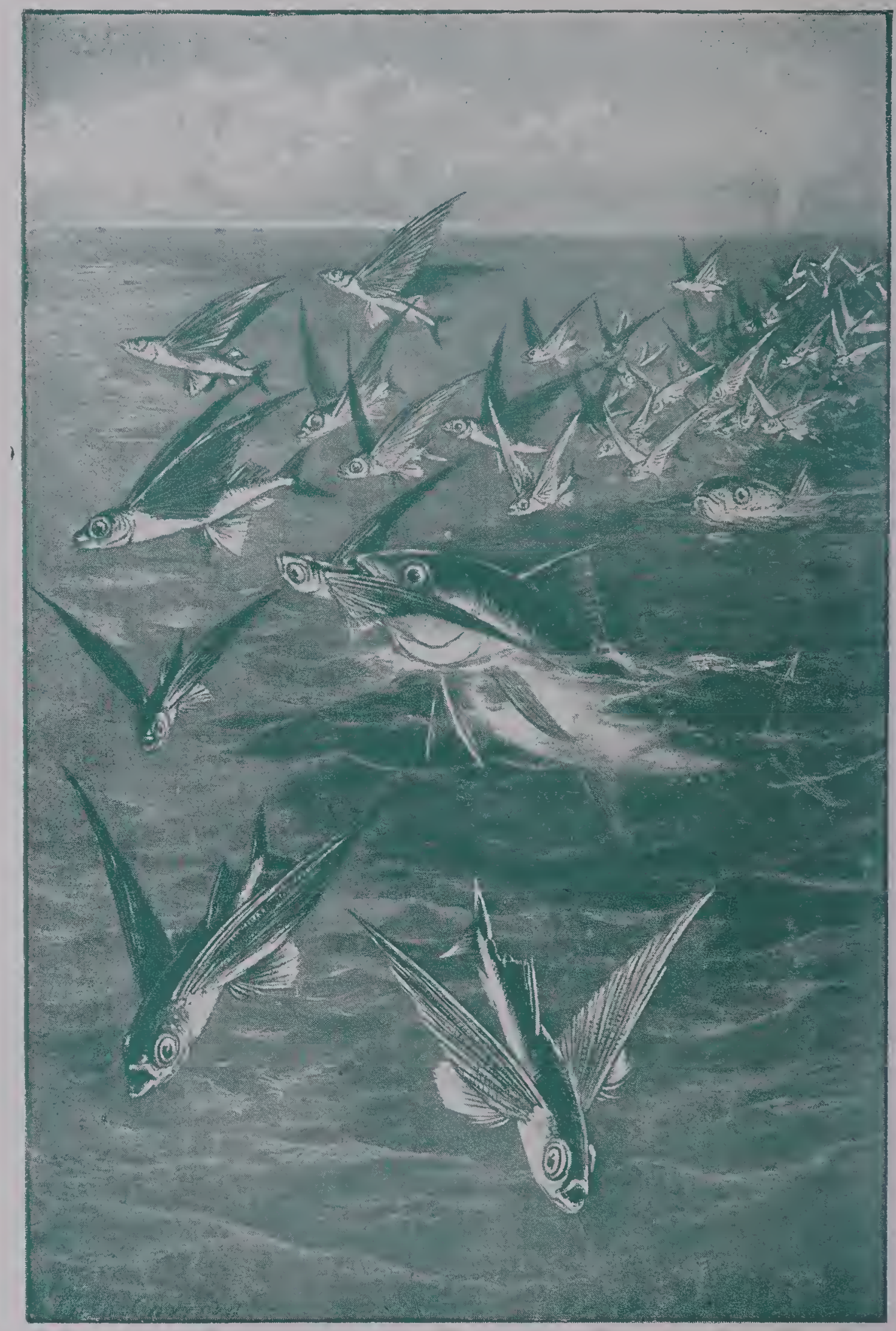

A SCHOOL OF FLYING-FISII ATTACKED BY ALBACORE.

[To face p. 225 . 


\section{Rapidity of Flight}

be seen streaming along very swiftly just beneath the surface, each leaving behind it a broadening track of light, until, as if at one impulse, the whole company suddenly leave the water, the points of their multitudinous exit gleaming in tiny showers of diamond spray. But sometimes in the dark, bewildered, they take the wrong direction, and may be heard striking the ship's side with a series of sounds like hammer taps, and occasionally a straggler, flying higher than the rest, strikes against a mast or a sail and falls on deck dead. I have sometimes seen blood and scales on a lowermast about twenty feet above the deck, proving not only the height to which the fish had risen, but the impetuous velocity of its flight. And it is quite a usual thing to find Flying-fish (where there is no cat on board) in the morning lying on deck, with their heads battered into shapelessness by the force of their impact against some solid part of the ship. Poor puss, however, whose lot on board ship is always a rather rugged one, learns with amazing swiftness that fresh fish are occasionally to be found in obscure corners about the decks at night, and when she does, very few of these succulent morsels find their way into human mouths.

The strangest instance, proving the velocity of a Flying-fish through the air, which ever came under my notice was on board of the barque 'West York' in the North Atlantic, homeward bound from Portland, Oregon. It was a lovely night, and with a favouring breeze the vessel was making about five knots an hour. Keeping the look-out upon the small deck forward, which is known as the top-gallant forecastle, was a loutish A.B., who from his laziness, stupidity, and uncleanness, was no favourite on board, all the rest of the chaps being pretty smart. $\mathrm{He}$ was sitting 


\section{The Flying-fish}

upon the capstan when last I saw him, dozing, I believe, from the position of his head. Suddenly, as the watch below and the unoccupied portion of the watch on deck were chatting, prior to the former 'turning in;' 'Cockney' rushed into the forecastle howling like a spanked brat, and holding both hands to the side of his face, from which the blood was trickling through his fingers. He caused quite a sensation amongst us, for it looked as if he had been seriously assaulted, and he, as soon as he could speak, plainly declared that he had been, by the skipper's son, who was second mate. He said that he was looking out on the starboard bow, when the second mate came up behind him and struck him so heavy a blow with his fist that it knocked him off the capstan.

As soon as he had recovered he rushed in to tell us, and he expected us to go aft immediately and make a row about it. But while he was thus expending himself I examined his temple, finding indeed the marks of a very heavy blow, blood and bruised flesh, and also two or three fish-scales! Saying to my shipmates, 'Hold on a minute,' I rushed up on to the forecastle head, and sure enough, underneath one of the stowed anchors, beside the cat-tail, I found the aggressor, a splendid Flying-fish, about a pound and a half in weight, with its head almost driven into its body. And, as a salve for his grievous wound, I gave it to the 'Cockney' for his breakfast.

In order that the Exocetus may indulge easily in these aerial excursions, it is provided with a very much enlarged swim-bladder, which, when inflated, fills the whole cavity of the abdomen. There is also in the mouth another bladder, which is filled with air through the gills, and both these inflations are performed automatically at the moment the fish leaves 


\section{Domestic Haunts of Exocetus 227}

the water. The bladders, of course, are kept full of air while the fish is on the wing, but the moment it touches the water they are deflated, allowing the fish to plunge as rapidly as it wishes to the limit of its depth, which is not very great. These bladders are an excellent substitute for the air cells within the bones of birds, and make of the fish a veritable bird while on the wing.

The spawning place of the Exocetus, in the North Atlantic, at any rate, is among the floating weed in the Sargasso Sea, the breeding place of so many sea denizens. Here I have often seen masses of ova large enough to fill a flour-barrel, and looking exactly like bunches of white currants, colour, size, and transparency all lending themselves to the illusion. No doubt whatever can attach to this statement, because the tiny fry with the yelk fastened to it still by the umbilicus were also often hauled up, and even to the naked eye were recognisable at that early stage as Flying-fish. But I am quite conscious that the question of the breeding-places of the Indian Ocean and Pacific Flying-fish is still a moot point. No one can imagine the Flying-fish migrating such vast distances as would be necessary if all of them bred in the North Atlantic. I should, however, suppose that they find, in all oceans, submarine forests of seaweed in the immediate vicinity of steep-to land where they can spawn, and amid whose dim intricacies their young descendants may be reasonably safe from the majority of their enemies. This sheltering of young fry is undoubtedly one of the chief ends, if not the chief end, subserved by seaweed all around the world. Without such shelter it is hard to imagine how any of the helpless fry would survive the attacks of their countless voracious enemies, the worst, perhaps, being their own relatives. 


\section{The Flying-fish}

The Flying-fish is probably one of the most prolific of all fish, not even excepting the herring. For it must be remembered that it is the staple food of all the larger pelagic fish, albacore, dolphin, bonito, and skip-jack, while undoubtedly it preys upon its own species more ravenously than do the strangers. I have caught a Flying-fish with another nearly half its own size jammed in its throat, and the greedy rascal had eleven smaller ones, ranging from one to three inches long, distending its maw. This fact of its exceeding voracity soon modified my feelings of compassion towards it. Like most people, I felt sorry for the poor persecuted fish, which appeared to know no moment of security, whose life was one long series of hairbreadth escapes; indeed, I often wondered how it was that any escaped at all. For, the attack of the dolphin, for instance, always seemed to me unerring. I never saw a Flying-fish missed by a dolphin, often as I have seen them chased, and numberless times have I seen the graceful sea-birds swoop down into the midst of the fleeing school and take easy toll of them while on the wing. But when I saw how ruthless they were themselves, and also how, in spite of the amazing numbers eaten by the larger fish and birds, there never seemed to be any diminution in the quantity of those remaining, I ceased to criticise the arrangements of the Creator, and reassured myself that the Flying-fish was as perfectly happy and as well provided for as are all the rest of His creatures.

The other species of Flying-fish, which I have not yet alluded to at length, E. nigricans, is quite an imposing fish. He has two pairs of wings, the ventrals being extended like the pectorals, only of course, less so. It is a handsome, if sombre-looking fish, its markings being black and silver instead of blue 


\section{The 'Guineaman'}

and white, while its fins are also black, with a transverse band of silver. I feel some little hesitation in speaking of the principal hue of this fish as black, because it is by no means a jet black, or even an ink black. But it certainly cannot be called anything else but black, since it is neither very dark blue nor deep brown. It is really a dull black, almost rusty, but of course when it is wet it is brightened somewhat. It grows to a length of twenty inches, and a weight of over three pounds, but it is very seldom seen of those dimensions by sailors. I believe its habitat to be but a small strip (comparatively speaking) of the North Atlantic, and I know that when one is caught at Barbadoes, the irrepressible negroes always allude to it affectionately as 'ole Guineaman,' showing their belief in its origin being the Gulf of Guinea. Whether that is so I do not know, having never been there, and not being able to find any allusions to the matter in books of Natural History, which, indeed, contain very little reliable information about the habits, etc., of deep-sea fish, however minute the anatomical details they may afford about specimens which have been captured, preserved and brought home.

There is a deeply rooted notion among seamen, from whence arising nobody seems to know, that in various parts of the world, regular fisheries of the Exocetus are carried on, but in a most peculiar manner. It is assumed that a glare of light is an attraction irresistible to the Flying-fish, and, in consequence, this failing of his is made use of to lure him to destruction. Boats go out at night, the darker the better, propelled by paddles, as being the most noiseless method, and having a net set like a sail upon a yard hoisted upon the usual mast, with its foot also spread 
out. A lantern is hoisted to the middle of this net, at the sight of which the fish fly towards it, strike the net and fall down into the boat. It is therefore considered to be the easiest form of fishing known. Unfortunately, in spite of the precise details of this description and the matter-of-fact way it is, or used to be, regularly told to the young deep-water sailor, it is nothing but a yarn. No such fishery is carried on anywhere, nor has ever been, although I do not doubt that every retailer of the story believes it. There is, however, a regular Flying-fish fishery carried on at one place in the world, and only one, systematically. Such few instances of Flying-fish being caught among some of the South Sea Islands do not count, as they are more or less accidental and not at all planned out.

At the beautiful island of Barbadoes in the West Indies there has been established for over a century a regular Exocetus fishery, which is carried on all the year round, with great average success. It furnishes the inhabitants of Bridgetown and Speightstown and the coast villages with their staple food; in fact, it is often said in jest that the 'Badians do not feel fed unless they have Flying-fish with every meal. It is almost universally cooked in the same way, that is, the bones are removed, and the fish not fried or boiled, but saute in gravy-not nearly so pleasant a method, in my opinion, as grilling or frying. But that is purely a matter of taste. The price fluctuates much, according to the catch, but happily there is no ' ring' in Bridgetown market. If the boats all return loaded to the gunwale, as they sometimes do, the price falls at once so low that the very poorest negro can get a meal for half a dozen hungry people for a tup, three halfpence, while next day the same money 


\section{The Barbadoes Fishery}

may only purchase one small fish. But none of the fish is wasted because there is a glut. It must all be disposed of rapidly, for in that torrid climate a very few hours will turn it putrid, and it would be a sin to throw it away, in the sin so what is unsold is distributed gratis to the poor. At least, I am now quoting what was the practice twenty-three years ago. By the law of compensation it usually happens that when Flying-fish are scarce, albacore, dolphin, bonito, or jew-fish are plentiful, all these abounding in the deep-blue waters which come up so close to the island shores.

The method pursued in this fishery is even more simple than that described in the yarn already given. The only gear needed are a few nets made on hoops some three feet in diameter, of about half-inch mesh, and with scarcely any 'bag' to them, two or three stout lines and hooks, for possible big fish, and a set of granes. The boat is usually sloop-rigged, and from three to ten tons, carrying the usual boat's gear, but always undecked. A few Flying-fish kept from the previous day's catch are the bait, very strong in odour and oozing with oil. Thus equipped, the boats put forth just before dawn, so as to be on the ground at the time of calm or nearly so. More fortunate than their northern brethren they are always sure of their weather; they have no need to consult the tides, and their season lasts all the year round. Moreover, there is scarcely any change in the hour of daybreak, and the weather is always warm, so warm in fact, that the fisherman's sole garment is usually a flour sack with three holes cut in it for head and arms.

Upon leaving the harbour the boats make all possible speed to a distance of about three miles off 
the land, where the water is the intense blue of midocean. Having arrived, the peak of the sail is dropped and the tack hoisted; in sea parlance, the sail is ' scandalised,' and the boat allowed to drift. By this time the gorgeous tropical sunrise is unfolding its ineffable glories, and great splashes of radiant hue appear and disappear upon the placid face of the sea. But the fishermen have no eyes for celestial beauty now. Bending over the side they knead and squeeze the semi-putrid bait in the water until it is broken up into minute fragments, which sink very slowly, and the exuding oil glazes the sea-surface until it is like looking down through a plate of clear glass.

Presently a few swiftly moving specks appear beneath. They increase in number rapidly, until the vast depth seems alive with them, oftentimes appearing just a mass of fish. Grasping the hoops of their nets on each side, the fishermen lean as far over the boat's gunwale as may be, and with the utmost caution to make no sound, pass the lower edges of the nets into the water as far out as they can reach. They press them downwards and draw them inwards, at the same time lifting them with their inner edges touching the side of the boat until they can pour their load of Flying-fish into her hold.

If the school be large and the work skilfully done, it is not uncommon for the boat to be loaded in an hour from one school, without appreciably diminishing its numbers. But it is exhausting work, and exciting withal, so that it often happens that an incautious move is made, a slight noise produced, and with one great flash of innumerable turning silver bellies, all close together, the school has disappeared. This may occur a dozen times in the course of the morning, or say from six o'clock until nine, the fish being so 


\section{Good Sport}

numerous and so very timid. Or it may be that for some unaccountable reason scarcely any fish are seen, and the fleet has to return practically empty.

But the most usual form of scare for the fish is the appearance of some of their natural enemies, bonito, albacore, or dolphin. Then the nets are put away, the lines are unrolled, and some real sport is indulged in, which, pace those lovers of high angling art who cannot sce any fun in fishing except with a rod, and who glory in beguiling the mighty tuña or tarpon by means of a rod and line no thicker than ordinary grocers' twine, has much to recommend it to people whose chief aim is to earn a living, but who have no earthly objection to a little sport thrown in. And so, taking it all round, this old-fashioned fishery of one of the least known, least understood sea people in the ocean, goes merrily on in a satisfactorily successful way, supplying the islanders with an abundance of wholesome food of high quality at nominal cost as a rule. For the average price is, or used to be, about four or five a penny, each as large as a goodsized herring. Guineamen, of course, fetch more, but they are very seldom caught.

Possibly because Barbadoes is so far to windward that these deep-sea loving fish do not fear to frequent it, it has a monopoly of the fishery, none of the other islands seeming to care for establishing a similar enterprise. I am inclined to think that from its position, so isolated and far out in the Atlantic, also its steep-to shores, the Exocetus has come to regard Barbadoes very much in the light of a ship which they can with safety approach quite near to. Certainly I know of no other-island or mainland in the world where Flyingfish are found in such abundance at so reasonable a distance. Not even Ascension or St. Helena, although 


\section{The Flying-fish}

both are in the heart of Flying-fish territory, and both are greatly frequented by all those larger fish which feed on the Exocetus. Barbadoes alone possesses the facilities for catching them, and the requisite energy to do so.

Flying-fish are also found in the Mediterranean, but not in any great numbers. Also in the Red Sea and Persian Gulf they are to be seen, but they are by no means plentiful. It would really seem as if the Flying-fish feels that nothing but the widest breadths. of ocean give him ample verge and room enough, so that, although he is tempted occasionally into the narrow seas, he never feels at home there, and is anxious to get out to the vast playing-grounds of old ocean. There, in spite of the hosts of his enemies, he leads a life of perfect freedom, his numbers, despite the amazing tax upon them, apparently never decreasing. But, as with all the other fish I have dealt with, he cannot be studied, his society cannot be enjoyed from the deck of the swift steamer. It is necessary to be in a leisurely sailing ship to realise, first, what the Flying-fish is; secondly, what he is capable of performing in the way of flight; and thirdly, how vast are his numbers.

Very vividly come to my mind the many occasions when I have seen more than a square mile of smooth sea-surface suddenly broken into foam by the upheaval of myriads of Flying-fish, who sped through the lucent air like an undulating wave of molten silver, and with a musical murmur like the hum of far-off bees. How often have these wonderful little fish, like the bonito, come just in time to save precious lives adrift in boats or on rafts! When all hope has fled, the last crumb, the last drop has been expended, there has fallen into the midst of the perishing ones these 


\section{Bizarre Flying-Fish}

succulent morsels, as if dropped from heaven. It is doubtful whether, of all the sea-people who do their best to show the sailor the infinite populousness of the sea, there are any for which he feels a greater regard than he does for the Flying-fish; although, of course, it grieves him to think that, owing to circumstances over which neither of them can exercise any control, he does not see as much of his little friend at table as he would dearly like to.

Under the head of Flying-fish I must treat of another interesting denizen of the deep sea, which is in very truth a Flying-fish, if far inferior in powers of aerial locomotion to the Exocelus. Two species of this strangely built, but exceedingly pretty fish as regards colour, are quite familiar to dwellers in our own towns, being often seen on the fishmongers' slabs.

The first is the Red Gurnard (Trigla cuculus), so called as to the second half of its pedantic title, because it emits a sound when captured much like a cuckoo. But it certainly is not fair to call it a deep-sea fish, since it is only found in comparatively shallow waters, on the bottom, where it feeds on crustacea. It is abundant on our coasts, and in consequence of its cheapness, is not thought nearly as much of as the excellence of its flesh entitles it to be.

The second is the Sapphirine Gurnard (Trigla hirundo), as quaint in appearance as the first, but even more beautiful as regards colour, a quantity of blue being interspersed with its deep red.

Now between these two, common as they are in our waters, there is one essential difference; the second is a 'flying-fish,' the first is not. The first, as any one may test for himself, at a good fishmonger's, has its beautiful fins quite normal in size, the second 


\section{The Flying-fish}

has the pectorals greatly lengthened, enabling it to skim along the sea surface for quite thirty or forty feet. But this is evidently only a prolonged leap, making of the outspread pectoral fins a sort of parachute to buoy them up. Again, an inspection of these fish, which may often be made at the fishmonger's, will at once show this, the weight of them running up as high as five pounds, and the comparatively small area of the pectoral fins forbidding the idea of flight, in the commonly accepted sense.

There are, however, two other species, Dactylopterus volitans and $D$. Orientalis, which approach much more nearly to the idea of true flight, although even they never perform the feats which the Exocetus is capable of. The first is common in the Mediterranean Sea, where it affords abundant sport to the homeward bound tunny or albacore. But, from a cursory glance at this Gurnard, one is compelled to wonder of what material the fish's throat must be lined, who ventures to swallow him. His head is armed with bony plates, whose edges are spiky and razor-sharp, his back is liberally furnished with dorsal spines, the anterior ones very long and sharp as a cambric needle, and even his sides bristle with keen-edged or pointed weapons. His armament therefore is such as to make him a most dangerous fish to handle, and the fact that he can be swallowed by albacore and bonito without inflicting any deadly injury upon them would seem to argue, first, that their throats must be armour-clad, and secondly, that digestion is with them a very powerful function.

The colours of these curious fish are very diversified. Brown, red, pink, grey, black, and blue are distributed over its body in tasteful markings, and when observed closely during its flight in the sunshine, the effect is 


\section{A Splendid Fellow}

very pleasing, all the colours being rich and bright as those upon a butterfly, and further accentuated by being wet and shiny. In these species the pectoral fins are very large, much larger in fact, proportionately, than those of the Exocetus, at least apparently. But on closer examination it is seen that the body of the Gurnard is much more stocky, and consequently heavier than that of the Exocetus, while the buoying up bladders are very small and ineffective. Apart from this knowledge it would be very difficult to understand why the Gurnard should not be a much better flyer than the Exocetus. For the wings, instead of tapering off towards the end, like those of the Exocetus (which much resemble a swallow's wings) actually broaden out, being considerably wider at the tip than at the junction with the body. They are also fantastically decorated with long protruding spines at the sides and ends, the ribs of the parachute, as it were, produced beyond the membrane, perhaps for protection but apparently for decorative purposes.

The second of these volatile fish is a denizen of the Arabian sea, Persian Gulf and Bay of Bengal, never being seen very far from land. It is practically unknown to sailors, but is often caught with hook and line by the hardly bestead native fishermen on the Coromandel Coast, who pursue their calling upon a wretched contrivance of their logs lashed side by side, with a few turns of coir spun-yarn, on which they can only maintain a kneeling position, and from which they are continually being swept by the sea when it is at all rough. They are there greatly esteemed as food, and credited with much greater powers of flight than they really possess. 


\section{CHAPTER XVIII}

\section{THE DOLPHIN}

W

HEREFORE, or when, or how sailors as a class agreed to call the lovely fish which is the subject of the present sketch a Dolphin is and must remain a mystery. It is the source of endless confusion, this mixing up of mammals and fish by calling them the same name, yet, such is the intense conservatism of the seafarer and the perfect continuity of tradition as regards nomenclature, that it seems impossible that the Coryphaena should ever be called by the sailor anything but a Dolphin, or the Dolphin (Delphinidae) anything but a porpoise, or indeed any of the smallest mammalia of the sea with the exception of the seals.

Sailors are as a class exceedingly unobservant and careless in their classification of the most familiar fauna of the sea, but once a fish or bird has a name given it, that name, however absurd, is bound to stick, and no amount of light shed upon the creature's habits, etc., will ever cause it to be altered. Perhaps after this small explanation I may be permitted the privilege of an old sailor, and call my subject, in defiance of scientific rules, the Dolphin. It is an easier name at any rate than Coryphaena.

The principal characteristic of this marvellously beautiful denizen of the deep sea is its iridescent colouring, of blue and gold principally, but so modified and changeable by each passing mood or pose of the 


\section{The Dying Dolphin}

fish, or play of sunlight, that all splendid hues known to man seem to be reproduced on its body. It flashes through all the colour-schemes imaginable with incredibly swift and dazzling effect, then as swiftly all the colours seem to blend into one dull silver grey, which renders the fish almost invisible amid the bright blue of the sea.

It has long been an article of poetic faith that the dying Dolphin is more splendid in his colour changes than he ever is during life; but from this, after long experience, I must emphatically dissent. It is true that when a Dolphin suffers sudden and violent death, such as being transfixed by the granes or five-pointed fish-spear in common use on board ship, his body does exhibit a series of swiftly changing colours, fairly vivid. But they are never so brilliant as those shown by the living fish, when in the height of his activity he hurls himself in arrowy flight after his prey, or springs perpendicularly into the sunshine, the spray falling from him like a shower of diamonds, and his glorious hues flashing in the glare of the sun, with an effect beyond the power of any artist to depict or pen to describe.

When, however, the Dolphin is caught with a hook and laid on deck to die, the kaleidoscopic changes are still apparent, but oh, so faint and dulled compared with those shown by the living fish, or even with the speared creature. And some time before he dies a dull leaden shade comes over his gaudy body, and never goes away again. It is permanent and unbeautiful, for some reason which I do not understand. Nothing in Nature I should say can give more pleasure to a colour-loving eye than the sight of a number of Dolphin on a sunny day, when the sea is smooth enough to observe all their motions properly. Not even the 
amazingly beautiful tints and shadings of a flock of humming birds can vie with the marvellous splendour of this wonderful fish.

A cursory examination would lead one to suppose that the Dolphin was a scaleless fish, as indeed is nearly true of the mackerel, with which the Dolphin has undoubtedly some affinity. But a little search will show that minute scales do exist all over the body, covered by a fine skin, and that around the shoulders the scales are fairly large and thickly set, so thickly indeed that in removing them it is possible to run the fingers beneath them, and tear off several square inches at a time, in a large specimen. And quite close to the head the scales blend in so closely with the bony plates of the skull that, if sufficient force be used, some of the latter may be torn off without being separated from the scale-sheets.

Like most other sea fish, the Dolphin has a medial line extending from the middle of the head to the fork of the tail, but unlike all the Scombridae or true mackerel family, this line is not composed as to its posterior third of horny conical processes like rudimentary armour, but is merely a dark line drawn as if with a lead pencil, as in the whiting, haddock, and cod. Anatomically this line is an elongation of the fifth nerve of the brain, but its use who can tell ? It is probably a survival of some elaborate organ which had lost its usefulness, and so became atrophied and disappeared according to Nature's inexorable decrees.

The fins of this elegant fish are in keeping with his other beauties. On his back, from the crown of his head to within two or three inches of his tail, he wears a dorsal fin half as wide as his body. In colour it is burnished yellow gold, and its contrast with the dazzling peacock blue of the back immediately 


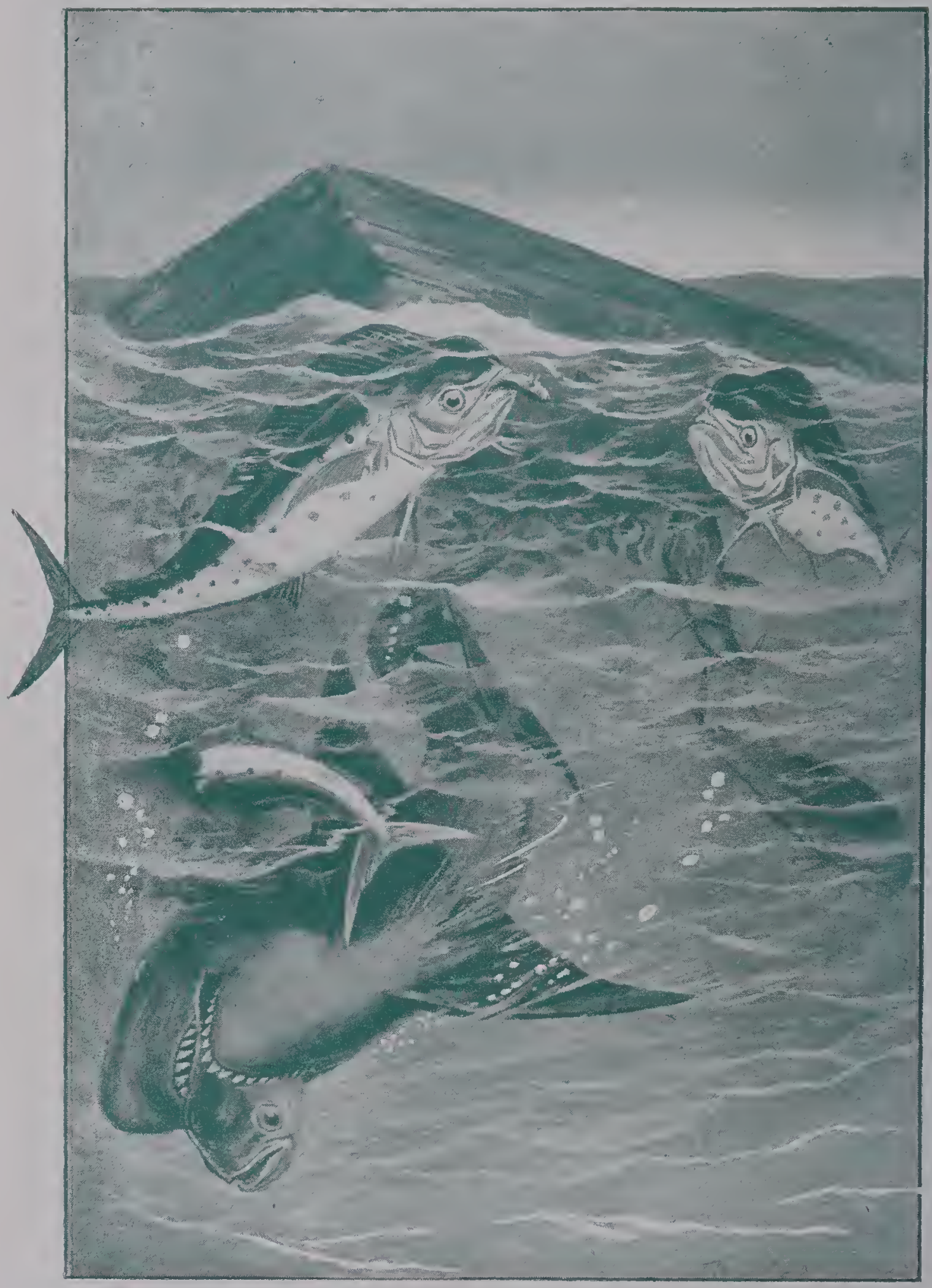

A SHARK SEIZING A DOLPHIN.

[To face p. $2+I$. 


\section{Elegance and Colour}

beneath it is exceedingly striking as well as pleasing. It is always carried erect, but sometimes, as when the fish makes one of its immense parabolic leaps after prey, such as a flying-fish, it seems to stand much higher than usual and to glow with greater intensity. It gives the fish a grand appearance and adds greatly to its apparent size. The caudal fin is very large also, deeply forked, and most elegant in shape. When the fish is in haste, its vibrations are so rapid that it seems to take an entirely new shape, and if the sun is shining it appears like two rays of flame branching out in the fish's wake, being of the same metallic hue as the dorsal fin. The pectoral, ventral, and anal fins are comparatively insignificant, as indeed is usual with what I like to call normally shapen fish. Only outré-shaped fish have these minor fins fantastically and hugely developed.

The general shape of the Dolphin is excellently adapted for speed. His head is high in front, almost rectangular, but presenting a sharp bow. The body behind does not thicken very much, the largest specimen I ever caught being, although six feet long, only six inches through. It was more than a foot wide though, and its mouth was a horizontal gash in its head that opened wedge-shaped and large enough to admit a fish six inches in diameter. Also it was well-furnished with exceedingly sharp teeth, in closely set rows, but quite small.

The female is precisely similar in appearance to the male except in the contour of the forehead, which recedes with a beautiful curve from the upper jaw, instead of being high and rectangular like that of the male. In colour she is quite as gaudy as her spouse, but in size, as usual, inferior.

Now with regard to their breeding-places, they 


\section{2 \\ The Dolphin}

are, like those of most deep-sea pelagic fish, wrapped in mystery. But although I would not care to be too dogmatic upon the subject I feel sure that the Dolphin deposits its ova in masses of floating weed such as the gulf-weed or Sargassum bacciferum of the North Atlantic. Even that, however, does not explain the breeding-places of those Dolphin who inhabit the Pacific and Indian Oceans or the Mediterranean, unless we may suppose that, like the albacore, the Dolphin circumnavigates the globe, in order to return to his favourite spawning-places. One thing is certain, they do not spawn at any depth, for they are an essentially pelagic or surface-fish. And they are never seen in the vicinity of land, except as in the case of such mountain peaks as St. Helena, Ascension, St. Paul's Rocks, etc., which, rising almost sheer from great depths, have bold, steep-to, precipitous shores, around which the Dolphin may be seen playing quite close to the rocks, apparently regarding them as a new and curious kind of ship. At least that is the impression made upon a sailor accustomed (in a sailing ship that is) to be accompanied in ocean's remotest solitudes by these wonderfully friendly and beautiful fish.

The habitat of the Dolphin is almost co-extensive with that of the sperm whale and albacore. But being apparently more intolerant of cold than either of these sea denizens, he is seldom found so far north or south as they range. Only when an exceptionally warm summer heats the sea-surface considerably above its usual temperature does the Dolphin extend his wanderings into unfamiliar regions, following his natural food, the flying-fish and squid, who, being like himself true pelagic fish, love to roam as far as they can out of their usual regions when the unwonted warmth of the water invites them to do so. I have seen them as 


\section{Modern Sea Disabilities}

far north as the Azores and have heard of them being seen in the Bay of Biscay; but, while I do not feel able to deny that this can be true, I feel sure that the conditions must have been abnormal in the extreme.

Now it may be considered an ultra-refinement of description thus to dwell upon the peculiarities of a creature which is quite unknown to the majority of people, and from the circumstances of the case likely to remain so. For not only is it a very small fringe of the population that goes or can go to sea far enough to see a Dolphin, but even sailors are being precluded from making the acquaintance of Deep-Sea People by reason of the passing away of the sailing vessel. There are very many sailors to-day who have done an enormous amount of voyaging to all parts of the world, yet have never seen one of these fish, which used to be among the most familiar objects to seafarers, because these essentially social sea inhabitants do not like the throbbing of the propeller or the swift rushing of the steamship. Much as they would like to forgather with a ship, they find it impossible so to do, unless she is propelled by sails. And so it comes to pass that the deep-sea fish are losing that intimate touch with man, which they have maintained for countless generations, to the exceeding benefit of the sailor.

My first acquaintance with the Dolphin was made at a very early age. It was on my first voyage, from London to Demerara, in British Guiana. The weather was exceedingly fine, and the trade winds quite light. As we crossed that weed-covered vortex in the North Atlantic so widely known as the Sargasso Sea, we were often hardly able to force a passage through the hay-coloured masses, so feeble was the impetus given to our bluff-bowed old craft by the laggard 


\section{4 \\ The Dolphin}

breeze. Occasionally we came to a great clear space in the midst of the surrounding aggregations of weed, wherein it seemed to my excited fancy there moved all the embodiments of my most fevered dreams, such weird shapes as only seemed possible of materialisation in a kind of waking trance. But suddenly, while moving slowly through one of the smooth waterglades, we came upon a large school of fish, numbering some thousands I should think, who swam in a compact body, as if moved by one common impulse.

When they all turned simultaneously, the flash given off by their bodies was as if a gigantic mirror had suddenly revolved, focussing the sun upon my eye. I was fascinated, spellbound. It had never before occurred to me that all over the great and wide sea we should meet with fish; like so many other people, I had imagined the sea to be a barren waste of bitter waters. Breathlessly I sought the only sailor on board from whom I was ever able to get any information and, full of excitement, led him to the rail, where I pointed out the school. 'Wha-what are they?' I gasped. He gave just one look, jerked out the word 'Dolphin,' and rushed away, leaving me wondering whatever was the matter.

He dived into the forecastle, emerging in a minute with a fishing-line, to the end of which was attached a stout hook and a burnished piece of tin. Running out to the bowsprit end he began to jerk the line up and down, allowing the shining lure to touch the water intermittently. In a minute he had a fish, the whole school having moved on to a spot just beneath him. And I had the privilege of fetching his catch in while he tried for another. He caught them so fast that I had no time to stop and examine them until the school shifted, which was not before he had caught eight. 


\section{A School of Juveniles}

Then the school having temporarily disappeared, he came in, and we gloated over the catch together. I of course, who had never hitherto seen a fish caught larger than a stickleback in the Serpentine, was full of amazement at their size, being about eighteen inches long and averaging three pounds weight each. But Joe told me that they were very young ones and were seldom met with like this, usually keeping concealed somewhere until they were much larger. And when he told me how large they really grew, I confess that I felt very doubtful of his veracity.

For the rest of that day I had no relief from my desire to see more of these pretty fish. I kept as careful a watch for them as if my life depended upon discovering them. But it was not until I accidentally glanced down the rudder trunk-a curious-shaped opening in the after-part of the quarter-deck which admitted the rudder-head, and down which there was plenty of room for a slim man to fall by the side of the rudder into the sea-that I discovered the school all closely packed under the ship's bottom, as if they were magnetically held to her sides. Whereat my wonder was again excited; but as my chum was now asleep I had to watch, and see if I could find out for myself why they thus clustered about us. It could not be for food, I reasoned, for the vessel had been newly sheathed with yellow metal just before leaving, and there were as yet no sea-growths, either animal or vegetable, upon her. And as I watched and wondered it was suddenly revealed to me why these fish gathered so closely about us. It was for shelter, for protection.

All at once there darted into the midst of their close-packed masses one of their own kind, but very much larger, one at least six feet in length and 


\section{The Dolphin}

proportionately wide. I saw them scatter, but aimlessly, as if they knew not whither to flee. And indeed they did not, for if some security could not be found hugging the underside of the ship, it most assuredly would be absent from the open spaces of the clear sea. The aggressive cannibal could for a brief space be dimly discerned as he darted to and fro amidst the frightened youngsters, and then the water became so foul with blood and floating fragments of fish still quivering with recent life, that I could not see more of the fray for a little space. When, however, we had passed beyond that befouled area and the transparent blue beneath enabled me to notice what was occurring, I saw that the aforetime solid mass, was, although still endeavouring to cling to the shelter of the ship, broken up into many little groups, which continually shifted their position, as if demoralised by fear.

Thus they remained with us until we again penetrated the mass of floating weed, when we lost them, for there they found better shelter than the ship could afford, besides what they must have needed badly, an abundance of suitable food. I have never been able to see a school of Dolphin younger than those were, although I have many times seen them in large schools of individuals somewhat more developed, but still clinging together, as if for mutual protection. I once boarded a derelict in mid-Atlantic which contained a large number of these small Dolphin. They had evidently, in rushing from the attack of one of their numerous enemies, plunged headlong into the gaping captivity of the main-hatch, which was completely uncovered and had its port coamings quite under the sea, the vessel being nearly on her beam-ends. The fish darted about between the tum- 


\section{Adult Immunity}

bling logs which composed her cargo as if they were quite at home amid their strange surroundings; but I could not help thinking that many of them must have got crushed to death down there.

The aggregate numbers of Dolphin in the ocean must be very great, but still quite insignificant, I should say, compared with the incalculable hosts of the better-known sea fishes, which frequent shallow waters and are of such value as food. For, except when they are quite immature, and, swimming together, appear to invite the onslaught of their enemies, who are of many kinds, they are never even seen in groups, much less in shoals. All their hunting is done individually, and although one seldom sees one Dolphin without others being near, they do not appear to fraternise at all. Perhaps in the presence of a common danger, like the attack of an albacore or a sword-fish, they might revive the memories of their youth and draw together for mutual comfort, but I very much doubt it. I believe instinct teaches them that the more widely separated they are, the more opportunities will be afforded them of making good their escape. Indeed, I am at a loss to imagine how any fish could possibly overtake the Dolphin to do him any harm except by stratagem, his amazing speed enabling him to distance easily any other enemy when unhampered by the company of many friends. I really believe that when once the Dolphin attains his or her full growth, which, owing to the systematic devouring of the younger ones by their congeners and other deepsea fish, is only the case with about five per thousand of those hatched, he or she is practically immune from destruction by any enemy except man. And, as is the case with so many other of the deep-sea folk, owing to the steady displacement of sailing ships by 


\section{The Dolphin}

steamers, man does not now often get a chance to do them any harm.

The food of the Dolphin, as before hinted at, is flying-fish and squid, with an occasional feast upon the young of his own species, or any other species that come in his way. I have, on several occasions, found in the maw of a Dolphin that I have caught, specimens of small fish that were quite unknown to me, fish that sailors never see except under similar conditions. So that the Dolphin is like most other fish, he has his special predilections ; but almost anything that is eatable in the sea he will eat. However, I firmly believed that he only ate living fish, that it was impossible to lure him with anything but an apparently living bait, and that, if the play of the bait were allowed to cease for an instant while he was near, he would immediately retire disillusioned, and no amount of coaxing would bring him back again.

But it so happened that one day, when the ship was lying as still as a ship can be at sea, it being a stark calm, several Dolphin paid us a visit. One came near enough to be transfixed by the granes skilfully hurled by the boatswain, but the others took the pointed hint and kept out of harm's way. The jerking about of a piece of polished metal fastened to a hook dangled from the jib-boom end quite failed to attract any of them. They kept at a reasonable distance from us when on the surface, and only drew near to us about the keel when they settled down into the depths.

The fish that had been caught was handed to me as usual for dissection, and in its maw I found some flying-fish that had been quite recently swallowed, and not at all injured. One of these I fastened on to a hook, and lowered it quietly into the translucent 


\section{Luring Dolphin}

water under the stern, paying out line until the flyingfish gleamed like a silver spot about five fathoms deep. Presently a Dolphin came stealing out from beneath the ship, where he had been lying in the shade, and leisurely neared my bait. I saw him put his nose to it, I watched him turn and take it in his mouth, and when it had entirely disappeared I struck as hard as I could, and caught the largest Dolphin I have ever seen, whose weight was forty pounds. By using the same means, I, that afternoon, caught three more large Dolphin, and fully established the fact that the moving lure was not essential. Afterwards I caught Dolphin with a piece off one of their own bodies, cut in the shape of a fish from the under side, where there is a silvery sheen upon it. I shall not soon forget the joy there was in the forecastle over that first catch. No one expected it, but every one was hoping for a breeze, in order that they might get an opportunity to catch some. For we were almost at starvation point, the provisions being so bad, and, moreover, scurvy was just beginning to show its awful symptoms upon some of us. The arrival of my fish changed all that, for all hands had three meals of fresh fish, and that by far the most sapid and succulent of all the deep-water fish, with the possible exception of the flying-fish, the latter being never caught at sea except by the accident of its flying aboard.

Unlike the albacore, bonito, skip-jack, and swordfish, the flesh of the Dolphin is white and full of flavour. Boiled, it is better than cod, only it has the drawback of being occasionally poisonous. Why or how it becomes so I do not know, nor have I ever heard any theory worth mentioning to account for it; but a curious belief of sailors in connection with it is interesting. They firmly believe that if a piece of silver be boiled 


\section{0 \\ The Dolphin}

with the fish, and the latter is unfit to eat, the silver will turn black; but since the presence of a trace of sulphur in the water would produce the same effect, I fear it is not a very reliable test. Moreover, as fish caught at sea by sailors is nearly always fried or baked, even that doubtful test cannot usually be applied, and in consequence the hungry seafarer has, as he vulgarly puts it, to 'go it blind,' and hope that he will not wake up with swollen head, distorted and discoloured features, and an acute sense of pain all over his body, these being the more evident symptoms of fish poisoning. It must gratefully be admitted that instances of poisoning by Dolphin are rare, and by bonito and albacore practically non-existent. It is only, as a rule, the curiously shaped and coloured fish caught in out-of-the-way harbours that are dangerous to the eater. None of them are deadly, except the patient be in a very poor state of health, or unable to apply the simple remedies indicated.

For some curiously finical reason the Dolphin has been supposed to have several different branches in his family; but like so many other creatures of the sea that have been credited with many ramifications of species, careful investigation has so reduced the supposed varieties that the most eminent ichthyologists now only credit Coryphaena with two branches, $C$. hippurus and $C$. equisetus. It may well be that even this last distinction will break down upon closer scrutiny, and only one variety be found to obtain all the world over. Still, it is very easy to understand how this opinion as to differing species may arise, owing to the fact that the young differ widely in their fin shapes and contour of head, also the colour arrangement is much modified as they grow older.

But a great difficulty confronts the museum 


\section{Sucking-fish Parasites 25I}

naturalist in the study of the deep-sea fauna. He is so greatly dependent upon stray specimens brought home for his observation, he cannot, in the nature of things, bring personal experience to bear, and he must theorise largely. Which of course tends to error, since it is, to a great extent, working in the dark. I have had a curious instance of this while preparing the present chapter.

In previous pages I have described the Remora, or parasitical sucking-fish, under the head of sharks, because every specimen I have seen, and they run into hundreds, have possessed all the well-known characteristics of the shark. The curious leaden and white hue of the body, the long upper lobe of the tail fin, the strange eye full of sinister expression, the scaleless shagreen skin, making a very good substitute for sandpaper, and the gill-openings, just slits in the side of the neck, instead of one large free opening spreading wide and admitting the water to the bloodred feathery branchiae inside; all these marked my suckers and stamped them as sharks. Only there was superadded the curious oval sucker on top of the head, by means of which the lazy creature attaches itself to its host, whether it be living or dead. Now I am told that the Remora is not a shark at all, but a mackerel. Of course, I can fully understand that there may very well be a species of Remora which is a mackerel, but that I have only seen the kind which has the shark characteristics I have absolutely no doubt whatever.

I cannot understand why so familiar a fish as it is, being certainly much more frequently seen at sea than the species which I do not know, should be unknown to the authorities. There is, therefore, all the more credit due to them for having rejected all the 
fine-drawn theories about the varieties of Dolphin, and reduced them to two, which is certainly all the varieties there are.

The life of the Dolphin must be an exceedingly happy one, ranging as he does the free breadths of all the oceans without hindrance of any kind. He knows none of the binding hamperings of a fixed abode, and even when the irresistible claims of the perpetuation of his race are upon him he still knows no restriction, is not compelled to go where traps and nets are laid by man for his destruction, as is the case with the albacore. Such enemies as he has he is well able to outpace, to elude, and, although it is certain that Dolphin are occasionally found in the stomach of a sperm whale, there is no doubt that their presence in that vast receptacle of all kinds of fish is almost, if not quite, due to overwhelming curiosity on the part of the Dolphin, resulting in his swimming down the gaping cavern of the whale's throat, whence he never emerges. Sometimes, too, he is taken off his guard and falls a prey to a shark or an albacore, but that I think occurs but seldom, for he has cultivated in a remarkable degree the faculty of keeping a bright look-out for the soundless approach of an enemy large enough to bite him in half and swallow him whole.

I once witnessed a case in point. It was in the Pacific Ocean on a perfectly calm day, when from my perch at the mast-head all that was going on in the blue serene beneath, illuminated as it was by the fierce vertical rays of the tropical sun, was most clearly visible through a pair of powerful binoculars. Quite close at hand floated a huge log of timber, the upper part of which was clean and fresh-looking, although wave-washed. Underneath, though, it was 


\section{A Movable Feast}

just a haven of refuge for a veritable host of deep-sea folks, all attracted to it by the harbourage it gave to such creatures as were capable of supplying them with food.

In the first place, it was closely covered with barnacles, those curious shell fish which abound everywhere at sea, being seemingly evolved out of nothing, so quickly do they appear upon any sea-washed substance, such as a ship's bottom or a floating log. They are attached to their home by a gelatinous footstalk, at the end of which their white shells, almost like those of a miniature mussel, except in colour, grow. Normally these footstalks are very short, or only about an inch in length, as when the barnacle is attached to a swiftly moving object. But on this log they averaged two feet in length, looking curiously like an immense mass of large-sized boiled macaroni growing out of the log and waving about with graceful undulations. This great tangle of iving filaments was densely populated by all sorts of small fish, crustacea of various kinds, etc. Outside, but very close to, were somewhat larger fish, eating their fill of the bountiful feast provided. And a little farther off still, coming and going with stealthy rushings, were several Dolphin, busily engaged in filling their maws with the smaller fish. It was a splendid exposition of the chain of interdependence subsisting in the sea, only of course we could not follow that chain far, the base of it being among the creatures invisible except to a high-power microscope.

But while I watched I saw a splendid Dolphin, his coat flashing its sapphire and gold under the rays of the sun, passing with leisurely tail-waving the side of the $\log$ nearest to me, apparently satiated with food. A dim shadow emerged from beneath the log just 


\section{The Dolphin}

behind him, shot upward, there was an eddy and a stain, and the gorgeous sea dandy was in two halves, one of which had disappeared down the throat of the lurking and crafty shark, who had so successfully stalked his elegant prey. Of course the second half rapidly followed the first down the shark's curious crescentic mouth, when he immediately concealed himself again. Three times did I watch the shark perform that manœuvre successfully, exercising an amount of patient self-restraint that was wonderful to behold, remembering how cruelly he was being tormented by the cravings of that enormous liver of his.

This was indeed the only occasion upon which I saw a Dolphin outwitted by a shark; as to being caught by so slow a fish as the shark is, the thing is unthinkable. I do not imagine, however, that the Dolphin is very intelligent, for I once saw a whole group of them, seven in number, caught one ofter the other from a flying-fish boat in Barbadoes Bay. We had been catching a goodly number of Exocetus, when the vast shoal from which we had been dipping out fish until our backs were nearly breaking suddenly vanished like the breath off a mirror. And then we saw the aforesaid group prowling around quite slowly, as if bewildered by the sudden disappearance of what they doubtless considered their food supply. A couple of stout hooks attached to heavy lines were each furnished with a still living flying-fish and flung overside, streaming away astern in the gentle ripple of our wake; for we were just moving a knot or so an hour. In five minutes the whole seven of them were inboard, each coming up to take the place of the comrade he had seen depart so hastily, without exhibiting a trace of any knowledge that there was danger to his life in the proximity of the boat. 
Commercially the Dolphin may be neglected. Except to sailors in sailing vessels, the only places where he is an object of any interest at all for food or sale are Barbadoes and St. Helena. At the former place he fetches a fairly good price, his flesh being held in high esteem and greatly prized as a change from the everlasting flying-fish, while in St. Helena he shares the privilege of being chased by the extraordinarily mongrel fishermen with the bonito, the albacore, and the horse-mackerel, the three being classed under the generic term 'St. Helena beef.'

To the poorly and monotonously fed seamen of long-voyage sailing ships he is, of course, always welcome, and some of my pleasantest recollections of old sea-days are associated with his capture. Seated aloft on the flying-jibboom end, with my line tipped with a piece of white rag blowing in a graceful curve just beyond the roll of foam roaring from under the advancing bows, it was exquisitely delightful to see a lithe gorgeous shape spring suddenly upward, seize my lure, and commence its useful journey to the hungry stomachs of my appreciative shipmates. To the joy of capture, of successful sport, was thus added the comfort of doing a kindly act, and I could even imagine the Dolphin sharing my satisfaction. 


\section{CHAPTER XIX \\ THE MACKEREL}

IFFICULT as it is to speak dogmatically upon such a subject, especially in view of the somewhat chaotic condition of our knowledge of oceanic ichthyology (hateful term), I feel fairly confident of my position in calling the Mackerel family the largest in the world of fishes. That is, I believe that there are more varieties of Mackerel than of any other kind of fish, and wider distribution of them, unaided as it is by the same set of conditions which permit many species of fish inhabiting the profound depths of ocean to be almost universal as regards the sea. I do not know of any members of the family who frequent rivers or lakes.

The head of the family, and from point of size the very king of fishes, the albacore, tuña, or tunny, I have already exhaustively dealt with, as also the bonito, the skip-jack, and the pilot-fish. So that in the following remarks these members of the great Mackerel family will, except for by-allusions, be left severely alone. But even so, there still remain such a sufficient number of fairly well-known varieties to be dealt with, as to make it necessary to condense the information greatly in order to keep it within bounds.

Naturally the place of honour falls to the Mackerel, whose name is a household one among us, and who is always quoted fondly (but with what truth I do not 


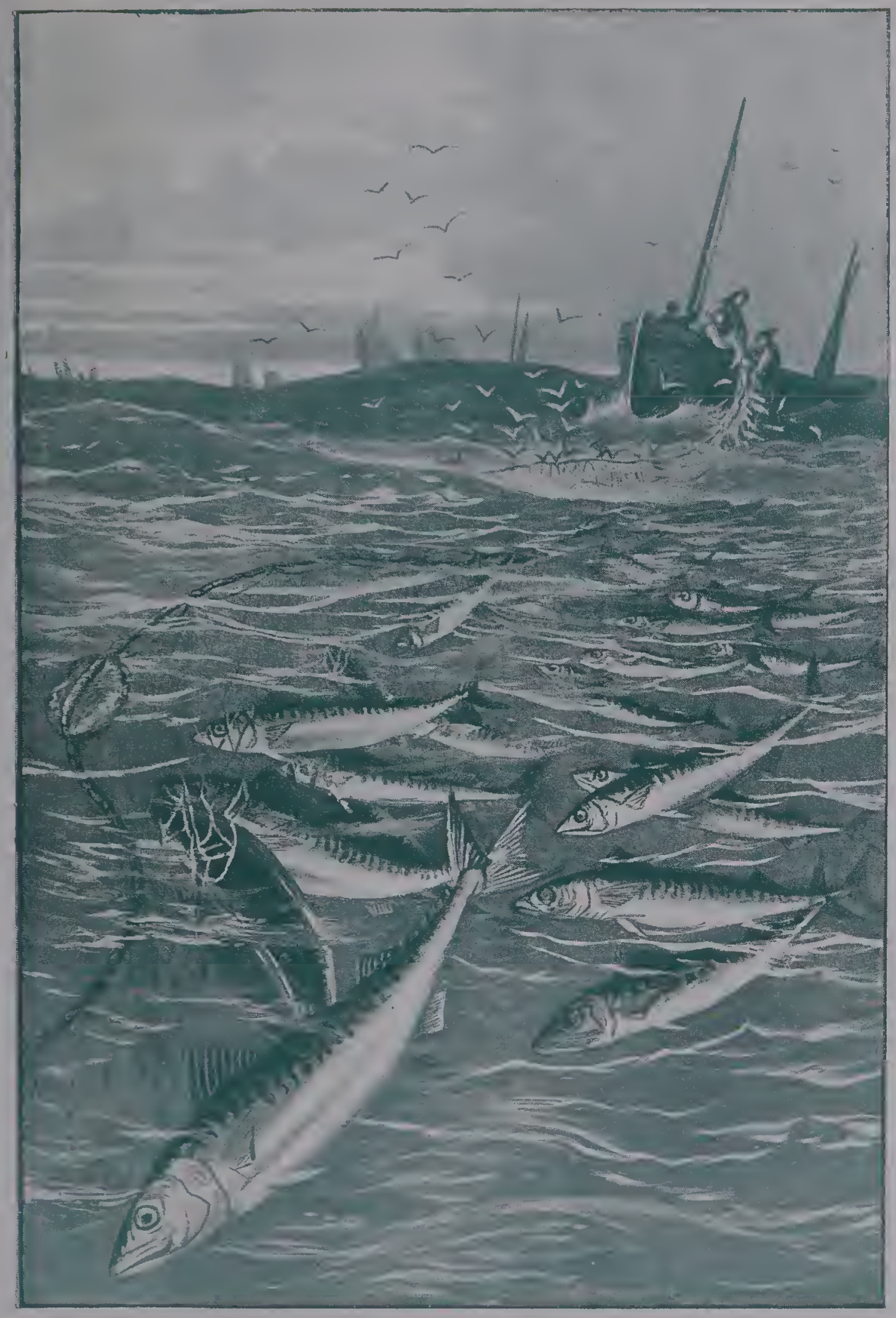

N̈ETTISG MACKEREL.

[To face t. 256 . 



\section{The Most Delicate Fish 257}

know) as being the subject of special Dominical legislation, in common with milk. It is an article of faith that milk and Mackerel may be sold on Sunday without breaking the law, on account of their non-keeping properties; but judging from the scenes always to be witnessed in the poorer quarters of London on Sunday, where whole streets are given up to vociferous. trading in any and every kind of article, it would seem that laws against commercial Sabbath-breaking have been allowed to fall into desuetude. And the one article that I can confidently aver that I have never seen sold in London on a Sunday is fresh Mackerel. The kippered Mackerel of course is sold, with bloaters, haddocks, and other merchandise of the 'wet and dry' fishmonger of poor neighbourhoods.

This may perhaps be accounted for by the extreme proneness of Mackerel to go 'bad.' No fish is more liable to sudden taint and the development of ptomaines than the Mackerel; under certain atmospheric conditions two hours are quite sufficient from the time of its capture to render it dangerous for eating purposes. And what is a great deal worse, the Mackerel may be quite unfit for food, but its conditions be unknown to even the most careful observer until it is cooked and tasted. Then indeed there is no concealment, for the taste is horrible and the flesh has become of a putty-like consistency.

It is rather difficult to understand how or why the Mackerel as an edible fish has attained to its present undoubtedly high degree of popularity among our workers. In point of flavour it is far surpassed by many other fish, notably by the much cheaper herring, a fact which is distinctly referable to its rapidity in getting stale. A Mackerel freshly caught and cooked is a delicious morsel, bearing no resemblance whatever 


\section{The Mackerel}

to its neighbour appearing on some inland table twentyfour hours later. But it is certainly a most beautiful fish in appearance on a fishmonger's slab, its lovely colours remaining even when it is stale, although the bright red of the gills has changed to a dull maroon. But its flesh is firm and easily separated from the bones, a great virtue in fish among people who have no cooks to prepare their food, and see that there is nothing to do to it at table but to put it in the mouth. It says much for the superlative excellence of the herring, that it remains in such high esteem in spite of its multitude of small bones, which are most dangerous if they get into the throat. Whatever the cause, the fact remains that, in spite of its comparatively high price and lack of flavour, the Mackerel is ex. ceedingly popular among our workers, and a joy to the costermongers, whose ability and energy in distributing perishable goods among the consumers is unimpeachable.

But apart altogether from the commercial aspects of the Mackerel, he is an exceedingly interesting fish in his ways, his mode of life. Ferocious in the extreme, he spares nothing that he can swallow, and few items of his prey can escape him, owing to his great swiftness, due to his elegant shape. Moreover, the colouring of the Mackerel is more perfectly adapted for concealment than that of any other fish. It is perhaps fairly well known that the reason why nearly all fish are dark-coloured above and light-coloured below is for purposes of concealment, for looking down upon them from the light the dark shade blends with the dark blue of the sea, while looking upwards to the light the silvery belly matches the water, which is almost colourless when looked through from that position; but the wavy transverse bands of light green and rich 


\section{Ferocity of Mackerel}

blue on the Mackerel's back blend so admirably with either green or blue sea that they render him almost invisible from above, while the iridescent sheen on the silvery underside of the fish makes an even more perfect combination with the glittering sea, as looked through from below. Consequently he plays a terribly destructive part among the smaller fish, such as the young of herrings, pilchards, etc.

Fortunately he does not attack in schools; if he did, a school of Mackerel would probably 'absorb' a school of herring, leaving not a 'wrack behind.' No, when in the amazing hosts of the school, although ferociously carnivorous as ever, the Mackerel seems to keep his predatory instincts in abeyance for the time, as if under strict discipline. Even then I imagine it would fare hardly with any straggling creature, helpless and edible, that fell in the way of that multitudinous march. Do I not remember vividly a story I was told as a child, of a man who, swimming out from Brighton, became surrounded by a school of mackerel, and was seen holding up his arms for succour, with scores of the ravenous creatures clinging to his flesh. The story went on to its gruesome climax of the recovery of the skeleton almost stripped clean, an hour after the man's motions for help were first seen. I cannot say that I place implicit reliance upon the story, but I have seen a school of Mackerel round the carcase of a dead bullock, and bear witness to the savage energy with which the fish in their thousands tore at the fetid mass of flesh. And so I would rather not go swimming in the midst of a school of Mackerel.

In common with his larger congeners, the Mackerel is strictly pelagic-he has no use for the bottom at all. It is even said by naturalists that the Mackerel spawns 


\section{0 \\ The Mackerel}

in the open sea, which hardly seems credible, even in view of our ignorance as to where the Coryphaena and bonito perform this most indispensable function. I have assigned to them the Sargasso weed as a spawningplace for seyeral reasons, chief among which is the vast amount of varied spawn which is to be found in it; but to credit a fish like the Mackerel, which appears in such illimitable numbers, with casting its ova haphazard upon the ocean with its ever-shifting currents, seems a stretch of the scientific imagination quite unreceivable. Moreover, while it might be imaginable of, say, the Coryphaena, whose numbers are not great as compared with other fish, and who never frequent shallow waters, it is not, it cannot be, so of the Mackerel, which is never seen at any great distance from land, and has its pick of all the most favourable spawning grounds as near the surface as it needs.

Unlike the herring, who never comes near the land, except in the multitudinous companionship of the school, the Mackerel are fond of roaming about quite independently, as if at times the restraint of the school galled them, and they needed to run loose for a little while, chasing their prey on their own account. These independent Mackerel give splendid sport, biting readily at a hook baited with a piece of red rag or a strip of the silvery skin of a Mackerel's belly, towed through the water at a brisk rate behind a boat. A fairly heavy lead is necessary to keep the bait sufficiently deep; if towed along the surface, the fish will not bite. There is no need for skill in baiting the hook, if the strip of skin be two inches long and half an inch wide, it is sufficient just to hang it on the hook by piercing one end, the fish being so ravenous as to gorge hook and all in its spring. These fish 


\section{The Mackerel Guide 26I}

taken with the hook always command a higher price than those caught in nets, for some curious reason which I do not pretend to understand.

So magnificently beautiful is the appearance of a school of Mackerel on a calm day when they rise to the surface in brilliant sunshine, that even the most hardened fisherman is moved by it, and if the unshaded eye should catch the reflected radiance of the congregated millions as they turn, it will feel a spasm of pain - the sight is too vivid for comfortable vision. Over those closely packed masses range, in screaming fussiness, flocks of sea-birds, busily looking for smaller fish fleeing before the Mackerel, for it must be but a very small individual that can be effectually dealt with by a gull or even a cormorant.

Swimming sedately in front of the school may often be seen a quaintly shaped fish, called by the fishermen the 'Mackerel Guide,' or Gar-fish. It is a long, slender creature, attaining in its full development a length of nearly four feet, and the thickness of a man's fore-arm. Its skin, while without the Mackerel markings, has the same sheeny iridescence and almost entire absence of scales, which seems to mark it, in spite of its dissimilarity of form, as one of the Mackerel family. But its chief peculiarity is its long, slender bill, like like that of a snipe, but furnished with closely set rows of needle-like teeth.

For all its elegance it is but a poorly flavoured fish, and though frequently seen in fishmongers' shops is little in demand except as a curiosity. Another strange possession of this fish is its blue bones, which, when the fish is cooked, contrast most strangely with the white flesh. Its association with the Mackerel must be pure coincidence, for I have seen it in parts of the world where, although some members of the 


\section{The Mackerel}

Mackerel family were to be found, as is the case almost everywhere, there were certainly none of the fish from which the whole family takes its name. I have caught the Gar-fish in the West Indies, in Madagascar, where there is to be found a curious variety, having only one long mandible, with the mouth on the upper part of it in the head, like a little trap-door in the head. The largest specimens I have ever seen were in Zanzibar, where, around the guardship 'London,' they would lie lazily sunning themselves, perfectly secure from molestation, because the crew were strictly forbidden to meddle with fish of any kind, for fear of cholera or poisoning.

The old naturalists believed that the Mackerel roamed as far afield as does the albacore, very much as they imagined the herring to do; but it has been found that, as with the herring, the Mackerel only retires into the deep water off shore for feeding purposes at certain seasons of the year, whence it comes in such amazing numbers during the summer. Occasionally there are found swimming amicably with the ordinary fish a number of much larger individuals, known as Horse-mackerel, which are so coarse and poorly flavoured as to be almost unfit for food. Thesc have also a very bad reputation, with what reason as far as our coasts are concerned I am unable to say, for being poisonous, as has also the delicate little fish known as the Lady Mackerel, a creature pretty enough to be made a pet of, like goldfish. The Horsemackerel of St. Helena and certain West Indian ports is, I know, poisonous, and should never be eaten; but this must be attributable to its food.

I would here remark in passing that, while all raw fish and meat is susceptible of being poisoned by the direct rays of the tropical moon, the Mackerel family 


\section{The Baleful Moon}

are exceptionally so. I have known, for instance, a bonito hung up under a boat where the moon's rays could not possibly have reached it for longer than an hour, to become utterly unfit for food, having a most foul taste, while it smelt as fresh as ever. This poisonous action of the moon upon raw flesh or fish is derided by some as being a fable, as also is the painful affliction known to seamen as moon-blindness; but there are certainly no two facts better known to, or more firmly established among, deep-water sailors than these.

The Mackerel is fairly plentiful on the American coasts, though not in such amazing numbers as over here. Not that they need it, having such stupendous abundance of other fish.

It is there salted down in kits and sent all over the country, but salted Mackerel needs an American palate, educated to the flavour of brine, to appreciate it. I have before noted how greedily all the Mackerel family absorb salt, making it almost impossible, once the salt has entered the tissues of the fish, to extract it again so as to make the fish eatable. But, after all, that is purely a matter of taste, and it is certain that salted Mackerel are in high favour with our cousins oversea.

And now we come to the consideration of the giant Mackerel known as the Sword-fish, or Lance-fish, as he should more properly be called, since the bone of the upper jaw which is elongated into a weapon is rounded and tapering to a point, much more like a lance than is the flat weapon known as a sword. It is somewhat of a relief to take up the history of a creature with some individuality, after dealing with fish that congregate in countless millions like the herrings and mackerel, and certainly among all fisis 


\section{4 \\ The Mackerel}

there are none whose lives are more romantic than that of the great Xiphias. It must be premised that there are several varieties of $X$ iphias ranging the oceans of the world, but the one I am best acquainted with is the Indian Ocean variety, of which a splendid specimen may be seen in the fish gallery at the Natural History Museum at South Kensington.

The Sword-fish, whose catching is quite a recognised industry on the New England Coast, is a dull-hued monster, ranging from one to two hundredweight, and frequenting those waters in fairly large numbers. $\mathrm{He}$ is taken by harpooning, the striker standing in a little 'pulpit' erected on the extreme point of the bow. It is good sport, if a bit rough, but a hard and precarious way of getting a living. As far as I am aware this is the only part of the world where the pursuit of the Sword-fish is engaged in regularly and systematically, everywhere else the giant mackerel being left severely alone, to pursue his triumphant way among the sea people, inspiring a terror among them which he can never feel, for there are none to make him afraid.

By reason of the terrible weapon he carries before him, and his amazing speed and dexterity in using it, he has always been the veritable ruler of all deep-sea fish, and the ruthless slayer of even the sea-shouldering whale. Only the sperm whale proves too doughty a foe for him to attack lightly, although I believe there are instances on record where he has successfully attacked cachalot cows. Before passing on to a brief consideration of the career of a typical Xiphias, I would like to say that my reason for calling the albacore the king of the deep-sea fish was on account of his size, as well as number and universality of range. There is no doubt that in courage and agility the 


\section{The Birthplace of Xiphias 265}

Xiphias is master of even the albacore, though in average size much inferior. The shark again, while far superior to the albacore in point of size, is in the first place hardly to be classed with fish proper, being rather an intermediary between mammal and fish. At any rate I still hold the albacore the king of all fish, while purposing to do full justice to the claims of the Xiphias.

To a sheltered nook of the Maldive Island reef bases there entered on a day a little company of Swordfish, and sauntering inquisitively around, seemed to survey with deepest interest every cranny of the wonderful place. It was a triangular area of dazzling white sand, almost exactly level, about two acres in extent and buttressed on all sides except just at the apex of the triangle, by almost vertical walls of live coral. Its floor was about twenty fathoms below the surface, which, shut in from the breakers by massive ramparts of rock, received, as if on a sapphire mirror, the rays of the tropical sun, and transmitted them in all lovely hues down to the silvern floor. Only a few small fish flitted stealthily to and fro over the smooth sand, or dodged in or out of the interstices of the coral, on the never-ending hunt for food. But when they saw the majestic forms of the Sword-fish come gliding in they fled, anywhere out of that dread company, whose presence spelt death to them if they remained.

The new-comers were twelve in number, ten females and two males, and having completed their leisurely survey of the place and finding it apparently well suited to their purpose, they glided gently over the bottom, waving their broad pectoral and ventral fins gently, as if they were still further smoothing the white sand. Having apparently settled matters to 


\section{The Mackerel}

their liking, the deposition of the ova began, and was carried on intermittently for the best part of two days, the male fish apparently keeping severe guard, and maintaining a strict supervision over all the proceedings. At last the task was over, the females languidly made for the exit, while the males lingered over the spots which the females had quitted, as if loth to leave them, until, as if alarmed at the prospect of losing touch with their consorts, the two great fish gave each a sweep or two in the clear water with their tails, and shot through the entrance between the towering bastions of rock as arrows flee from the bow.

In an hour they had rejoined the females, guided by unerring instinct in their track, and placing themselves at the head of the little company sped onward in search of food, their long fast having made them furious with hunger. Presently they fell in with a great school of bonito, who, taken by surprise, became utterly demoralised with fear, and huddling together in one compact mass permitted the ravenous monsters to dash again and again into their midst, with such velocity as to split sometimes four bodies into fragments at one blow. Such fragments were not immediately devoured, but when the slaughter was over the Swordfish swam hither and thither, gorging themselves in leisurely fashion upon the dismembered bodies of their cousins, until, surfeited, they turned away and left the befouled area to a shoal of small scavengers, which had during the great meal kept respectfully at a distance.

But now let us return to the spawning ground. There upon the speckless floor of sand lay evenly spread countless thousands of eggs, each large as a marrowfat pea, and almost invisible by reason of their pearly transparency. The dark spot in each, that 


\section{The Perils of the Ova}

should have made them visible, was in every case in the lower half of the pearly globule, which was half hidden in the soft sand. Very gently the warm current glided over them, so gently that no ripple, even the faintest, disturbed their repose or the fecundating operations going on within them. But here and there a tiny fish almost matching the sand in colourlessness swam invisibly along the pearly rows, culling now and then a delightful morsel in the shape of an ovule a little plumper than its neighbours. And though these ghostly visitors were very small their appetite was amazingly developed, for each of them was responsible for the disappearance of some dozens of eggs in the course of an hour or two's swim, which, considering that none of the depredators were more than six inches long, was evidence of extreme voracity. Now and then a bright shadow would glide phantomlike through the clear space, apparently just evolved out of nothingness, there was a moment's contact between it and one of the egg-eaters, and, presto, the latter had disappeared, as does a bubble when it bursts. And thus the balance of Nature was adjusted, for this is only a specimen of the constant interchange of commodities going on.

The enemies of the hatching eggs were, indeed, so numerous even in this sequestered spot, that as the days went by their numbers dwindled to such an extent that it seemed almost an impossibility that any of them should survive till the emergence of the fry. Even the tiny crabs, which are ubiquitous, although some of them were less than half an inch across the carapace, were continually employed in lugging away the savoury morsels to their home crannies beneath the rocks, like ants carrying away provender for storage. They were frequently sucked in, egg and all, 


\section{The Mackerel}

by wandering fish during these predatory journeys, but their exit from one stage of usefulness into another was so sudden and easy that no one could connect any idea of tragedy with it.

Still, in spite of all the influences that were arrayed against them, and as a proof of their amazing numbers, there came a day when thousands of tiny fish suddenly appeared, as if at a given signal, each carrying with it attached by a cord the yolk of the egg it had just quitted, upon which it would subsist for the next forty-eight hours. And never during its career was the fish in such danger of sudden extinction as now, when, about in full view of hungry enemies, the attached yolk added to its conspicuousness and hampered its movements, and it seemed a manifest impossibility for it to escape. Certainly the thinning out of the young Sword-fish now reached its most acute stage, for not one in a hundred survived. Yet all this selection and survival of the fittest had been arranged with unerring wisdom and accuracy - not one of those tiny creatures was devoured without its going being according to plan.

In what out-of-the-way holes and corners the young fry spent their early days, upon what tiny morsels of food they fed and grew strong, and what amazing and multitudinous hairbreadth escapes they had before attaining to the moderate size of one foot in length-all this proportion of their life history is hidden from us. When next we meet with them they have grown sturdy, predaceous and swift. Although only a foot or so long, they have already developed many of the qualities which will presently make them the undoubted rulers of the fishy world, yet at this age they have, allied to their undoubted ferocity, a large amount of caution which prevents them 


\section{The Young Warrior}

allowing another species of fish larger than themselves, and therefore a possible enemy, to come too near. Already they have taken to that semi-independent mode of life which is the preparation for their fullgrown loneliness-they do not associate with one another closely, although there are usually a goodly company of them within communicating distance of each other. Henceforward their progress towards maturity is rapid. Each day sees them essaying some new feat of endurance, some fresh act of aggression towards other fish, which gains for them, besides accelerated growth, increasing confidence in their own wonderful powers, such as nothing but the exercise of those powers can give.

It is now time to single out one splendid young specimen from the flock. He is a yard in length, exclusive of his sword, which protrudes from his upper jaw about nine inches. Every fibre of his comely body is surcharged with nervous energy - to watch him balanced in the still blue, every fin extended but without a suspicion of movement, even of life, save in the glare of the brilliant eyes or the glowing hues of the body, is to gain a great idea of latent power. No ancient warrior was ever uplifted with haughtier pride in his battle plumes than Xiphias in his magnificent dorsal-fin, which stands erect, blazing with brightest blue, from his head to his tail. It will be noticed that now he has entirely forsaken, as disdaining it, the shelter of intricate reefs, no longer does he creep warily, at several fathoms' depth, from one point of refuge to another. No, at last he has come out in the open prepared to assert his position before all his world, impelled thereto by an innate force, of which he knows nothing save its effect upon him.

As he lies there apparently immobile, there is 


\section{The Mackerel}

communicated to him by a series of vibrations the presence near at hand of some creatures, almost certainly enemies, but possibly victims. An almost imperceptible flash of the beautiful tail, a quiver of all the fins, and like a gleam of light he has sped forward to see. It is a little band of porpoises, perfectly harmless to fish like himself, but the native blood-thirst is awakened, the lithe tail sweeps scythe-like from side to side, and in a moment he has launched himself at the flat black flank of a sea-pig, in which his sword buries itself up to his eyes nearly. With a perfectly indescribable movement he sterns clear, describes a great circle, and, in spite of the great speed of the terrified and deeply wounded mammal, again buries his weapon deep in its vitals. But then, upon the slackening of the porpoise's speed consequent upon the tremendous drain of blood, the rest of the sea-pigs swarm round, made ravenous by the smell, the sight, the taste of blood. And soon there is a horrible cannibal feast going on, brother tearing brother into fragments, while like some destroying demon the infuriated $X i p h i a s$ wheels and stabs incessantly without obtaining any of the spoil for himself, except a taste of the blood, which only seems to increase his hunger.

That onslaught was a great mistake, involving as it did such a waste of energy without any resultant reward. But the young Sword-fish can only learn by the action of the twin teachers of experience and instinct, and the lesson just received is in nowise lost. In future, except for sheer love of destruction, he will not attack such creatures as he cannot devour. So for a long time he ranges the warm tropical seas proudly slaying and devouring all that he needs to assist him in his rapid development, until at last we behold him, eighteen feet long, with a 


\section{The Thirst for Blood}

weight of four hundred pounds and a sword nearly two feet in length.

$\mathrm{He}$ is now practically immune from pursuit or damage by any of the deep-sea folk, unless he sleep and let the wily shark slip up from beneath and snatch a ghastly mouthful from his middle. Or the saw-fish glide along and rip him from end to end. But while these dangers are very real, they are seldom experienced. As a rule, the watchfulness and wakefulness of such a sea denizen as the Sword-fish secures him from surprise. And the shark, no matter how hungry, must be quite sure of his prey before venturing his cowardly carcase in such an enterprise.

As the Xiphias grows to his full size he becomes aggressively valiant. Unlike most of the sea people, who only hunt for food, and that obtained keep peace, the Sword-fish longs, apparently with irresistible desire, for some foe worthy of his attack. This it is that impels him to launch himself like some living torpedo at the vast bulk of the whale, for the sheer savage delight of stabbing viciously again and yet again at the yielding living mass before him, even if, as in the case of the enormous bowhead, with its two feet thickness of blubber, he cannot draw blood. To bear away, impaled by one swift and terrible blow, the newly born calf from beneath its mother's protecting arm is a supreme delight, and one too that yields solid results in the shape of food, for the tender body of a young whale is easily divided by repeated blows of the sword.

But this fiercely aggressive spirit has its drawbacks too. As, for instance, when the Xiphias attacks a sperm whale, and, meeting the impervious mass of the head, rebounds helplessly, to be caught before recovery between the huge mammal's lethal jaws 
and devoured. Or, when hurling itself against the hull of some becalmed ship, it falls, with skull shattered to fragments against the steel, by the force of that tremendous impact. That this is no freak of the imagination may be proved by an examination of the sword of a Xiphias shown in the Natural History Museum of London, which is driven eighteen inches through solid oak planking and beam. It needs little calculation to show what the effect upon the fish would have been had that ship been of steel instead of oak. And there is very little doubt that such an occurrence is common enough, one of the few ways in which the sword-fish comes by his end, except by reason of his failing powers. Then, indeed, the scavengers of the deep, swift to note the waning forces of their great enemy, make a determined onslaught upon him and save him the misery of a lingering old age. This latter, it may be remarked, seldom falls to the lot of any deep-sea citizen. Even an aged cachalot, we may assume, is not allowed to die of senile decay.

A pleasant little member of the mackerel family, called the Pomfret or Brama, has always been an especial favourite of mine. The peculiarity about them is that they only make their appearance near a vessel in a calm. In the profoundest solitudes and depths of ocean these essentially sociable little fish, having suddenly been materialised as it were out of the surrounding apparently vacant blue, will presently be discovered clinging closely to the side of the ship, generally about the run and around the rudder. They will occasionally venture alongside as far as the bow, if the ship be making no headway at all and the sea be like glass, but they exhibit the utmost unwillingness to leave the side of the ship for a single moment. 


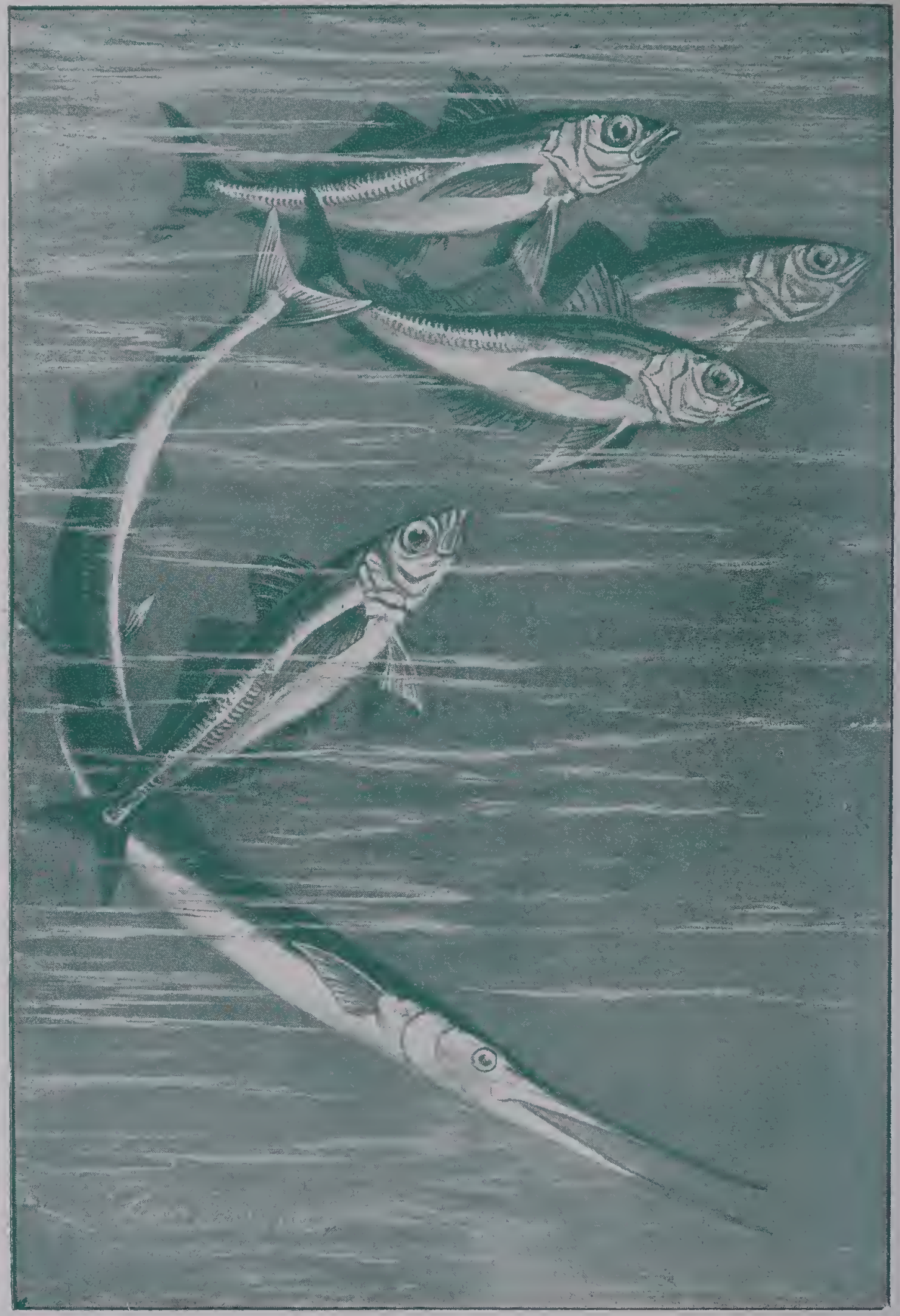

HORSE MACKEREL AND GARFISH.

[To face p. 273 . 


\section{The Most Sociable Fish 273}

Whether they come for protection, or food, or both, I have no means of knowing, but their appearance so far from land and over such profound depths is certainly very curious. They take a bait of meat readily and are very sweet eating, although I never caught one larger than half a pound weight. In shape they resemble a perch, but, as with mackerel, there is an almost total absence of scales and, as with the albacore, there are some horny conical little plates arranged along the posterior third of the lateral line. All around Australasia there are to be found congeners of this little fish, called by sailors Cavallé. They grow to a large size compared with the Brama, being often caught twenty-five pounds in weight. Also many of them are more shield-like-wider, that is, in proportion to their length. They are almost entirely silvern in colour, and the effect when, in hauling one up on a brilliantly sunny day, it suddenly turns its broadside to the sun is perfectly dazzling to the eyes. They are a splendidly game fish, as well as being very good eating.

Of the Echineis Remora, or Sucking-fish, of the mackerel tribe, I cannot speak positively. I have never seen one, although of the shark-like suckingfish I have seen many hundreds and caught many scores. According to ichthyologists, however, it is fairly plentiful and acts in precisely the same way as does the Remora, of which I have written before at considerable length.

It must not be imagined, because of the conclusion of this chapter, that I have dealt in any way exhaustively with the Scombridae. As I premised, only a few fairly well-known specimens could be dealt with in the space at my disposal, while the family is the largest of all known in the mighty ocean. 


\section{CHAPTER XX}

COD

7 HE Cod family of the Deep-Sea People is, with scarcely a doubt, the most valuable to mankind of any. Whether we consider its readiness to be caught, in spite of the deep and stormy seas which it inhabits, the vast range of its habitat, which is almost co-extensive with the shores tenanted by the white race, the ease with which it may be cured for keeping, and the esteem in which it is held by the dwellers in all Roman Catholic countries, or study the romantic character of the fishery, we must find the natural history of the Cod of absorbing interest. And that in spite of the fact that the Cod itself is by no means a romantic fish. He is not beautiful by any means, his flesh, though white and flaky, and under proper treatment sufficiently firm, has not the flavour possessed by many other of our edible fishes. His habits are regular, he is most accommodating in the matter of food, and as to what he will take as bait on a hook-I have caught Cod in New Zealand for experiment with a lump of coal tied to a piece of spun yarn. On all of which accounts the Gadidae family have claims upon our notice, which are not surpassed by those of any other inhabitants of the deep and wide sea. Dr. Hartwig ranks the Cod next in importance to the herring in its importance to man, but one may be permitted to disagree with him, without questioning his great authority and wide research. 


\section{The Chief Food Fish}

At any rate, I have ventured to put the Cod first, and firmly believe that I am justified in so doing.

To the Cod family belong also the Haddock, the Whiting, the Ling, the Pollock, and the Rocklings, all valuable food fishes, but especially the Haddock, which, in its smoked form, runs the smoked herring very closely in its hold on popular favour in our own country. Naturalists also include the Hake, and I suppose they are right, although for my part I fail to see anything about a Hake which can give him a claim to any relationship with the Cod, and therefore shall refuse to say anything about him here.

The principal and most valuable characteristic of the Cod is its amazing fecundity. It has been calculated that a single fish will deposit nine millions of eggs, a number which in its vastness simply bewilders us, for we cannot at all realise what such a mighty host means. Yet so numerous are the natural checks placed upon the too rapid increase of the Cod, that there are never too many for the seas they frequent to contain and provide for ; in fact, it is safe to guess that out of those nine millions of eggs probably not more than as many tens attain to maturity. Around the British coasts are favourite breeding grounds of the Cod, where in comparatively shallow waters he runs the gauntlet of his countless foes, escaping in such numbers as to make the Cod-fishery a lucrative form of the fishing industry.

But nearly all Cod and codlings caught on our coasts come to market to be sold fresh, except in Passion Week, when every fishmonger's shop becomes suddenly full of wet salted Cod temptingly folded inside out and garnished with lemons. The Cod lends itself amicably also to keeping fresh on ice, although it must be admitted that between Cod freshly caught 
and Cod that has been kept fresh in ice for some days there is a vast difference, even if people who have never been in a position to taste both are exceedingly sceptical of the fact.

Judging from what we are permitted to see of his manner of living when young and in shallow waters, the Cod passes a very pleasant, peaceful time of it. $\mathrm{He}$ is troubled by no problems of life, nor does he ever need to exert himself to obtain food. Plenty of it always seems to come his way, and when one kind is exhausted he turns to another, or leisurely strolls off, a few billions at a time, to another feeding ground. On the South Coast of England during the autumn codling are very plentiful ; fishing in the most primitive sailor-fashion, I have caught off the North Foreland in an afternoon twenty dozen, every one of which had its maw literally crammed with little crabs, making me wonder at what I could see must be the amazing numbers of these well-known crustacea.

But sporting fishermen disdain the Cod; he gives no sport. No finesse is needed to hook him, rather considerable delicacy of touch and quickness of striking is required unless the fisherman does not mind extricating his hook from the bottom of every fish's stomach. So voracious are they that they just gorge the bait, hook and all ; they do not nibble. And when they are hooked, except for a heavy, lumpish pulling as they are hauled upward, they make no play, which is just what renders them so welcome to the fisherman with his long-lines, trawl-lines, or buiters, as they are indifferently called, according to the place where they are used.

As the fish mature they move off shore into deeper water, until fishing for them becomes heavy labour. It is a severe tax upon the strongest physique to be 


\section{Most Easily Caught}

continually hauling up heavy fish from depths of from two to four hundred feet. And therefore the longline system of fishing is welcomed. It consists in having a line, say; a thousand feet in length, with a hook snooded on by a short tail about every three feet. These hooks are all baited, and the line is paid out from a boat which is rowed slowly along until the line is stretched along the bottom, both ends being held in position by a buoy at the top of the water and an anchor or sinker at the bottom. After a certain time has elapsed, which varies according to circumstances, the line is hauled in and the hooked fish, who, apparently finding themselves unable to get away, have just accepted the situation with philosophic calm and ceased to struggle, are disengaged and dropped into the boat. Then the line is re-baited and set again, while the boat hurries back to the smack to get the catch packed in ice so that it shall not spoil.

But in spite of the marvellously prolific character of the Cod, and the great extent of sea around our coasts which is exactly fitted to its needs, there are many and bitter complaints heard among the fishermen of the grave falling off in supply, and a general idea that legislation is needed to conserve the fish or it will be exterminated. Now it ought to be, I think, perfectly clear that, in the case of such fish as Cod, herring, or mackerel, the utmost efforts of which man is capable can have no appreciable effect in reducing the numbers of the fish available for catching. Especially when it is remembered what incalculable myriads of these fish are eaten by their natural enemies in the sea, numbers to which man's paltry toll are but as it were the stragglers from the main army. That the scarcity of Cod around our coast is not, cannot be, due to over-fishing seems so certain as to 
hardly require stating, yet the fact remains of the scarcity, and it needs to be accounted for in some other ways, although most probably if we did account for it we should find ourselves powerless to prevent its increase.

On the other hand, judging by what is to be seen on any morning at Grimsby or Billingsgate during the season, the supply of Haddock, first cousin to the Cod, shows no sign whatever of diminution. The Haddock comes to London almost direct from the sea, whence he is netted by trawls in immense numbers, in such a manner as to make one feel on witnessing the arrival and dispersal of a consignment as if they never wished to taste the fish again. It is, like all the Cod family, of a naturally slimy character, almost as much so really as the eel, but on its first appearance from the sea, multitudinously squirming in the pouch of the great trawl net, shows no trace of unpleasant appearance. But then it is dumped into the hold of the vessel and almost at once loses its cleanly grey and silver, exchanging it for a dull, greasy-looking neutral tint. Transferred from the hold of the vessel into iron tanks each holding a couple of tons or so, two of which just fit on a flat railway truck, it is whisked off at full goods speed to Billingsgate, undergoing on the journey a further process of deterioration, aided by the melting of the rough dirty ice with which it is plentifully mixed.

At Billingsgate it is sold by auction in the open street outside the Custom House to crowds of waiting fishmongers. Immediately a purchase is made, men, who are hardly distinguishable, by reason of filth and slime, except by their size, from the fish they stand knee deep in, shovel the mass of fish into the buyer's cart which is backed up to the wain bearing 


\section{The Great Home of the Cod 279}

the tanks. When the cart is loaded (it looks a singularly disgusting cargo) the purchaser rattles off with it to his shop, and in due time the dreadfully dirty mass of fish passes through a series of operations in back premises, often mere hovels a few feet square, and reappears as windrows of bright 'smoked 'addicks' on the sloping boards of the front shop. But the intermediate process does not bear thinking about, if we would ever eat smoked Haddock again in comfort.

But to find the Cod in all his glory it is necessary to cross the Atlantic. On the north-east coasts of the United States and right along the Nova Scotian littoral are found great areas of comparatively shallow sea, the broad Atlantic here allowing the land to rise to within less than a dozen fathoms of the surface in many places, and in one, the terrible Sable Island, which has well been named an ocean graveyard, a long snarling bank rises some few feet above the surface and constitutes one of the chief dangers of the stormy Nova Scotian coast. These banks vary in area from a tiny patch of some ten or fifteen square miles to the immense breadths of the Grand Bank off Newfoundland, as large as that great island, and at one spot culminating in the world famous Virgin Rocks which break in a gale of wind, so nearly do they approach to the surface. I do not know that any calculation has ever been made of the aggregate area of all these North American banks, but it must be some thousands of square miles. And over the whole of them, varying of course according to season, roam the placid Cod in almost undisputed possession of the greatest and most prolific fishing grounds in the whole world. Of course other fish are found around there too, the lordly halibut for instance, but as the proportion of any other fish 
to Cod is only about one in a thousand it is too small to be taken into account.

Now the Cod is manifestly not an adventurous fish. Like some domestic animals, he conceives it to be his primary duty to get fat, and to that duty he gives all his powers. But getting fat presupposes an abundance of easily obtained food. And here, if anywhere in the world, it is to be found. Squid; how could I ever have asked the question: "Why the squid ?' As well ask why grass, hay, mangolds, or any of the herbs and roots upon which our domestic animals raised for food are fed. But their food has to be provided for them by us, and sometimes the providing thereof presents a very serious problem when the elements are unpropitious, necessitating the operations of commerce on a gigantic scale. But the squid, at certain seasons, appear from their mysterious breeding places in the unsearchable recesses of acean in numbers like the grains of sand on the seashore for multitude, and spread their countless myriads over these ocean banks just where the Cod can gulp them down at its leisure. Also, and incidentally, the squid provides the fisherman with his best bait, for a piece of tough tentacle properly impaled upon a hook is not easily dislodged, and in the hands of an experienced fisherman such a bait will serve for the capture of several fish, no mean advantage in point of time when the Cod are biting well.

But so vast are the armies of the Cod that even that mass of squid is presently devoured, all except those who are, one would say, miraculously preserved to reproduce the needed supply for next season. Long before the pinch of hunger can be felt by the Cod, however, comes the capelin, beautiful little fish (Salmo arcticus) which appear to be the fry of some large 


\section{Marvels of the Unseen 28I}

fish that is so prolific that its surplus billions must needs come here to be disposed of, lest they should become too numerous and create a famine in the sea. Moving in almost solid masses across the banks in certain given directions, feeding themselves upon the myriads of minor creatures with which the sea is everywhere teeming, they are met by the Cod, who quietly work their way through the shoals eating, eating, ever eating.

What a wonderful sight it must be, could anybody but witness it, that mass of life, those square miles of closely arrayed food fishes moving slowly from point to point over the swarming surfaces of those submarine plateaux! Conceive, if you can, how infinitesimally small, in comparison with the area inhabited by the Cod, is the space occupied by the whole of the fishing fleet, would be the room taken up by all the fishing fleets of the world could they be collected there. As for the diminution in their numbers made by man, it is so trivial by comparison with those numbers, nay by comparison with the toll levied upon them by enemies of their own sphere, that it is not worth taking into account. For the area covered by the hosts of fish is so great, and the point fished by even a fleet of vessels is so infinitely small by comparison, that the capture of any at all shows how closely crowded they must be down there in the unseen. And if the united catch of all the fleet for one year were put together it would probably be less than the number of fish swimming at any given time during the season within the area of one square mile.

The ' Bank' fishery, as it is called, is an intensely romantic, highly dangerous and terribly hard calling. Readers of Captains Courageous will probably have realised that to the full, as far as reading vivid descrip- 


\section{2}

\section{Cod}

tion of a thing can make it real to one's senses. But I very much doubt whether it is possible to make any landsman realise what it means to ride at anchor in the open ocean far out of sight of land, groping in the unseen by the aid of what becomes, as in Disko Troop, a real instinct, for a dearly won livelihood. How can comfortable people ashore realise what it means to be shut up in a tiny vessel, anchored out at sea in the track of the swift, mighty, ocean-going steamships? Even on the clearest, most beautiful night the little schooner, with her glimmering riding light in the fore rigging, is such a tiny speck upon the great lonely sea. But when the dense white veil of the fog closes down in eddies of thickest cloud, so that the bow of the little craft is not visible from her stern, the sense of loneliness and of danger becomes almost unbearably heightened.

And strangely enough, whereas when it was clear the ocean looked so wide that the chances of one vessel meeting another to do her harm, seemed almost impossibly remote, in the smother of the fog it is almost equally impossible to avoid the conclusion that your vessel, like a magnet, will draw the ocean greyhound down upon you, and sweep you in one age-long minute of agony out of the world of being. Yes, it is an adventurous life, and a splendid set of men are those who lead it.

I have never been more astonished at the difference between my preconceived notions and the reality, than I was when, on a visit to Gloucester, Massachusetts, the metropolis of the Cod-fishing industry, I saw the fishermen ashore. Clean, well, even fashionably dressed, gentlemanly, stalwart men. Perhaps I was fortunate in coming across a picked lot, but there they were, looking as unlike the conventional fisherman 


\section{The Vast Export of Cod 283}

as possible. One could hardly picture them groping through the growling waves in their tiny dories on the banks while laying their trawls, or covered with blood and slime, knee-deep in Cod at the gutting and splitting, or down in the stifling hold, dimly lighted by one feeble lamp, packing the cleaned and boned fish in layers of salt, so closely that when full she rides almost as deep as if coal-laden.

For these Cod are not caught for immediate use, nor is the fisherman's toil confined to luring them from their deep-sea feeding grounds into the well of his vessel or her ice-boxes. He must needs prepare his catch for the first stage of their long journeys ere they reach their legitimate goal in people's stomachs all over the world. Time was, and that not so very long ago, when the Cod on reaching port were dried and sorted according to size and quality, then sent to their various destinations packed in barrels or even in loose crates.

From this method there was no change. It produced the bacallao beloved of the Spanish-speaking people and sent to them all over the vast continent of South America as well as to the mother country of Spain. It found great acceptance, even in poor Italy, whose hungry masses can ill afford to buy imported food except at very low rates. The smallest, meanest of the catch, little fish of half-a-pound to two pounds, went to the West Indies to be bought in pennyworths by the negroes. Some even came to Ireland, with the Atlantic rife with fish at her doors. So great was the export trade in dried salt Cod.

But now a cleaner, tastier development of the traffic has sprung up. Instead of making the succulent fish look like slabs of dirty wood, high-smelling and salt as brine itself, the fish is taken from the hold of 
the vessel, washed, dried so that it does not drip; that is all. It is carefully freed from bone (the sea process only ridding it of the main bones), cut into neat squares of meat that have no skin or any particle of uneatable matter attached to them. A number, say six, of these squares are pressed together, are neatly fastened with string, packed in a pretty parcel and, behold, the clean, newly caught, lightly salted Cod is ready for transportation among the seventy million people of the United States, most of whom are exceedingly fond of 'Cod-fish balls' (made of fish and potato and fried brown) for breakfast. So that now only the inferior fish not considered good enough for home consumption is exported.

Practically nothing is wasted of the Cod. Even the offal which is flung overboard goes to nourish those that remain to be caught perchance some other day, so that it cannot be said to go unutilised. But such an immensely valuable product as cod-liver oil needs only mentioning as one of the greatest gifts the ocean makes to ailing mankind-a specific in wasting diseases that has no equal. Even the swim bladders and tongues of the fish are saved, and, salted down in ' kits' (little tubs), are sent all over America. They look, before cooking, like pieces of wet white kid, and when ready for table are lumps of glutinous jelly, which need some getting used to by strangers before they can be eaten with comfort. But they are highly esteemed in America, and with reason, for they are, without doubt, a most nourishing and economical food. They are much too salt for British palates, but the average American loves his food as salt as brine, and so they just suit.

It may seem unfair of me to have made no mention of the great share which Canada and Newfoundland 


\section{The Southern Cod Banks 285}

have in this amazing harvest of the sea, but no neglect is intended or imagined. It is one of the principal businesses in many small coast towns, and without the Cod no one can guess what would become of the hardly used Newfoundland fishermen. That muchneglected colony of ours has many grievances, but one of the chief is that, situated in the very middle of the most valuable fishery in the world, she sees the best part of it taken away from her by others, and she is compelled to bear upon her flanks the open sore of a French colony, whose reckless inhabitants are a positive menace to her interests, whose behaviour is of the worst, and who apparently cannot be removed by any international amenities whatever. ${ }^{1}$

It is a far cry from Newfoundland to the Cape of Good Hope for us, but not for the distribution of fish. For off the Cape of Agulhas (which is the southernmost point of Africa, and not, as is popularly supposed, the Cape of Good Hope) and to the eastward of it, there is a plateau rising from the sea-bed to within thirty and sixty fathoms of the surface, nearly ten thousand square miles in area. This is known as the Agulhas Bank, and is the chosen resort of Cod almost exactly similar to those caught on the Grand Bank of Newfoundland.

But whereas one place is the scene of one of the most lucrative fisheries in the world, the other is turned to no account whatever. When people talk as they do occasionally about the populations of the world outgrowing the food supply, they really should pause and think a little while. It is interesting to see how little comparatively of the world's possibilities in the

' Since the publication of the first edition of this book, I am happy to say that the open sore of St. Pierre Miquelon has been removed from Newfoundland by diplomacy. 
way of feeding mankind have yet been dealt with, and also how prodigally man wastes Nature's bountiful gifts. Here, in this easily accessible portion of the sea, where the weather is far more temperate than off Newfoundland, although the gales and waves are, if anything, more severe, there are fish enough to feed the whole of the European population once or twice every week of the year.

And they are absolutely unmolested by man. We really cannot take into account the infrequent sailing ships briefly becalmed on the bank, whose crew hurriedly snatch a sample of this ocean wealth as they drift homeward. I vividly remember the last time but one that I rounded Cape Agulhas, when I was second mate of a large Liverpool ship, the 'Britannia.' We were crossing the bank when, during my watch, from midnight till 4 a.m., it fell a stark calm. In anticipation of its doing so I had bent three hooks on to the deep-sea lead line, to which I had attached the hand lead of seven pounds. I baited the hooks with fat pork, and as soon as the vessel's way ceased I dropped the line. I got bottom at sixty-five fathoms, and only five minutes after felt a splendid tugging at the line. The night being very cold I had a heavy coat on, but before I got my fish on board, I was streaming with sweat. For I had two fish, one weighing twenty-four pounds and the other twenty, while the seven pounds of the lead brought the load to nearly half a hundredweight to be hauled up through nearly four hundred feet of water.

I dropped my prizes with a crash on deck just over the captain's head, and he, a most enthusiastic fisherman, was up with a couple of lines in two minutes. The deep-sea lead-line was discarded and proper tackle used, with the result that in an hour we had 


\section{I turn Fisherman Indeed}

forty splendid fish, none under fifteen pounds in weight. And the most singular part of the business was that those fish most obligingly followed our lines up, or else, which is hardly thinkable, they were thick all the way down, for the last few we caught nearly at the surface, having decreased the depth to which we sunk our hooks at every cast. Then came the breeze, to which we made sail and departed from that wonderful fishing-ground.

The coasts of Australia and New Zealand abound in fish, but especially Cod, Rockling, or, as they are there called, Rock Cod. They are of two kinds, the red and the blue, both, I think, superior to the grey Cod of our own seas, but the blue is reckoned by far the best. In fact, it fetches nearly double the price. They move in shoals as our home Cod do, following their food, whatever it may be, far up into land-locked bays and estuaries, as they do in Newfoundland and Nova Scotia, where I have seen one of the huge native dogs dive off a pier and emerge with a fine Cod in his mouth, which he proceeded to devour in leisurely fashion.

This habit of theirs resulted in my making an extensive acquaintance with them once-the only time in my life that I was ever a 'professional' fisherman. Whaling, of course, is excluded. I was stranded in Port Chalmers, moneyless and unable to get a ship. Lounging miserably on the wharf one day, an old boatman of my acquaintance came up and said:

'Why don't you go fishing? The Cod are in the harbour, and Jimmy the curer round the flagstaff point will give you eighteenpence a dozen for all you catch.'

' But I've no boat,' said I, ' nor money to hire one.'

'I'll lend you a boat,' he replied, ' and charge you 
half-a-crown a day, which you can pay me out of your earnings.'

I thanked him, and started; fortunately I had lines and hooks; I was seldom without them during my seafaring days. In an hour I was well down the bay and had joined a little flotilla of boats, whose occupants were all busy hauling in Cod. In five minutes I was as busy as they, but sorely handicapped by the leakiness of my craft, which necessitated me baling with one hand and fishing with the other. Nevertheless, fish were so plentiful, and I was so fortunate, that by sunset-I had gone out at I p.m.I had caught a gross of fish, whose average weight was four pounds. I took them to the smokehouse and received eighteen shillings for them, at which I was mightily pleased.

Altogether that week my fishing brought me in four pounds, and I felt as if I were on the high road to fortune, when the Cod, who had only, I suppose, been on a visit, departed again, and my occupation was gone, for within the bay, where alone my boat was of service, I could not find a single Cod. On the last day I caught but a single fish, and that was a huge lean Ling.

This curious relative of the Cod seems to be a compromise between a Cod and a conger eel, and there are not wanting those fishermen who believe that it really is a hybrid. Its head and shoulders are exactly like a Cod, colour, barbels on the lower lip (a kind of feelers) and all. But the body tapers away just like an eel's with a dorsal fin that runs almost round where the tail fin should be, and continues along the belly as a long ventral. The one I caught was nearly six feet in length, but so attenuated that he did not weigh more than twenty pounds. I found or this occasion that 


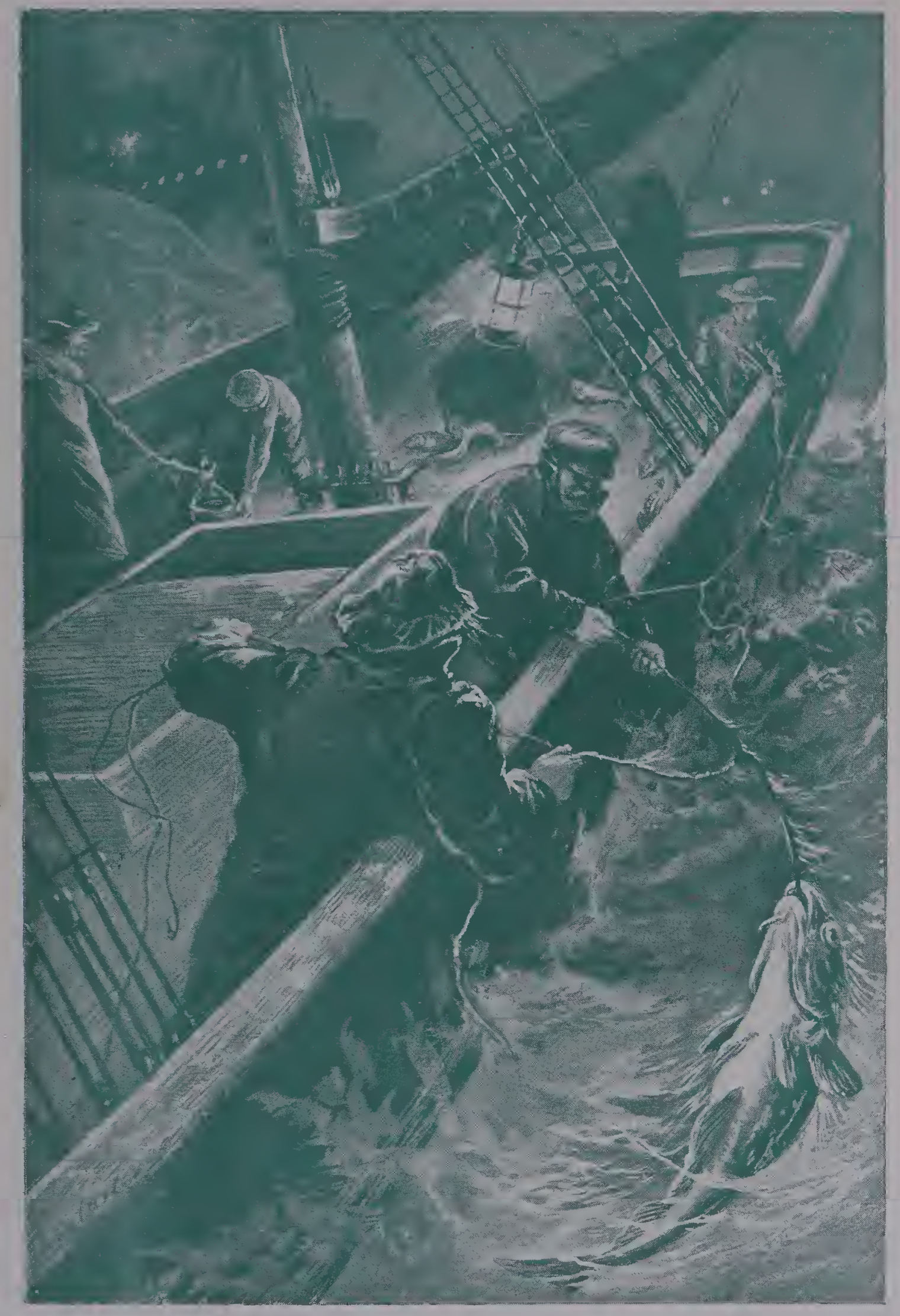

LIYE FISHINT FOR COD ON THE " BANKS.

$[T 0$ face $p .258$. 



\section{Varieties of Cod}

the habits of the southern Cod were far less regular than those of the Cod of our own seas. They appear to have no settled banks, feeding grounds where one may always find them at stated seasons, but wander in fairly large companies wherever food is plentiful.

Before leaving this subject finally, I would like to say that Rock Cod are not confined, as are the grey variety, to temperate and cold waters. I have caught them in so torrid a climate as that of the Gulf of Mexico at a depth of seventy fathoms. But I suppose that the rule of low temperature at certain depths, making fish who affect those depths almost world-wide in their habitat, will apply to Cod, even though he is not, I should say, ever found at a greater depth than a hundred fathoms. That, however, is quite deep enough for the standard temperature (about $3 \mathrm{I}^{\circ}$ F.) of the deep sea.

A very interesting little member of the Cod family, well-known to all of us, is the Whiting. It is caught in great quantities round our coasts and off the shores of Holland. It is essentially a fish to be eaten fresh, the delicacy and whiteness of its flesh being entirely spoiled by any attempts to cure it. More than that, much as it is prized on account of its delicacy of flavour and appearance, it is not too much to say that no one who has not tasted it within three hours of its capture can have any idea how delicious it really is. The same thing, of course, applies practically to all fish, no animal food growing flavourless and stale so quickly, but the probability is that of all the fish we eat there are none which it is so imperatively necessary to eat fresh if we would really have them in perfection as the Whiting. It is a small fish, being rarely caught above three pounds weight and averaging about a pound. 
The Pollock is another member of the Cod family of rather better flavour than the chief of his tribe, as well as more elegant in shape and not so slimy. But he is much scarcer and more select, always being regarded by fishermen as a far superior fish to the Cod. $\mathrm{He}$ is found of a goodly weight. I have myself caught Pollock in the Bay of Fundy weighing from seven to ten pounds. They are highly esteemed in Nova Scotia and New Brunswick, where I have seen them exposed for sale after being smoked, haddock fashion, and very delicious eating they were.

But none of the allied members of the Cod attain to any comparison with his great size, which sometimes runs up to close upon eighty pounds, except the Burbot, a true Cod, almost indistinguishable from his celebrated congener, but an inhabitant of fresh water, and, as far as is known, never going near the sea. In the rivers of this country, such as the Trent and the Cam, where he is to be found, his average weight is only two pounds, but in the great streams of Europe and America he attains a weight sometimes of over twenty. There is another species of Cod found on our coast known as the Coal-fish, but it does not call for any special remark here. 


\section{CHAPTER XXI}

\section{THE HERRING}

CTRICTLY speaking, the subject of the present $\checkmark$ chapter should not be allowed to enter this honourable company at all, since it is to comprise only deep-sea people, to which so great an authority as Dr. Günther emphatically says that the Herring does not belong. It has long been imagined that the Herring, our common Herring that is, from whom over fifty different species derive their title, spawns in the Arctic regions, and at stated periods pursues its way in unimaginable numbers through the deep sea until it strikes our coasts, when it rises to the surface and is thus brought within reach of the fisherman. But this idea is now scouted by ichthyologists. They tell us that the Herring never goes far from its spawning grounds, which are in shallow waters. That the immense shoals of Herring from which our fishermen take their toll have come up from deeper water a little farther off shore where they have been feeding and getting plump in order to spawn, which accounts for the fact that the Herring in full season is always full of roe or milt, and when they have spawned they are no longer fit to be eaten. Any one who has ever tasted a Herring in the latter condition will cordially endorse that statement as an indubitable fact.

The romance of the Herring is 2 most fascinating 


\section{The Herring}

one. Although there may be some doubt as to which is the most valuable from a statistical and financial point of view, the cod or the Herring fishery, there can be no doubt at all as to which is the most ancient and, as far as Europe is concerned, most popular. The Herring has often been proudly dubbed the king of fish, but the name is inappropriate. The Herring is a vulgar fish, beloved by the people, who sniff its fragrant aroma, as, in the guise of the bloater or kipper, it splutters on the gridiron, with lively anticipations of a savoury meal. A fashionable fish it cannot be, because of its cheapness and because of the aroma aforesaid, which, in the eyes or rather the nostrils of poor folk, is one of its chief recommendations.

The Herring is almost the only fish which the selfish autocrats of our great fish markets allow to be retailed cheaply, and it is no uncommon thing to see fresh Herrings not twenty-four hours from the sea being sold in London streets by the poor man's purveyor, the costermonger, at four and even six a penny, or at less than a penny a pound. And even at that rate there is considerable room for profit between the catcher and the eater. When one boat in a night sometimes draws from the sea over a quarter of a million fish, and could, but for her limited capacity and the fear of breaking the nets, take more than double the quantity, it is easily seen how cheap the fish may be, especially when it is invariably taken near shore. Another thing, although the Herring dies almost instantaneously upon leaving the water, it does not become stale very quickly - that is, there is less difference between Herring just out of the water and those twenty-four hours landed than there is noticeable in almost any other fish under the same conditions. 


\section{Good in Every Way 293}

Moreover there is no fish which lends itself so easily to cheap curing, or which when cured has a flavour greatly superior to that of the fresh fish. Salted cod is good fish no doubt and has great value, but compared with the fresh fish it is vastly inferior in point of flavour. But delicious as is a fresh Herring fried or grilled, a bloater or a kipper is certainly far more savoury, although perhaps a trifle too rich for delicate stomachs. And they have the advantage of keeping for a long time if not allowed to dry. The high dried Herring, ' ham-cured' Herring, or ' Glasgow Magistrate,' as irreverent people call it, is a great favourite with the poor, but it is intensely salt, and certainly has its demerits as a thirst provoker, leading to an increased consumption of beer, which among the class with whom it is a favourite is quite superfluous.

The salt or pickled Herring is not at all in favour in this country, but in America and on the continent of Europe is greatly liked, especially in Holland and Germany, where it is eaten raw. I well remember my disgust when, while discharging a cargo of mahogany in Rotterdam, the foreman of the stevedores stopped a Herring vendor and purchasing half-a-dozen fish from him, tendered one to me. I smiled and said I had eaten my breakfast, and anyhow there was no means of cooking the fish. 'Oh' said Hendryk, 'cooking would spoil them ; we eat them like this.' And taking one by each lobe of its tail, he ripped it asunder lengthways, skilfully ejected the backbone, and devoured the fish with great gusto. Prior to that the only people I had ever seen eat raw fish were the South Sea Islanders, and I had fancied it a savage accomplishment.

But whether salted, smoke-dried, or eaten fresh, the Herring as an article of food fills a position quite out 


\section{The Herring}

of all proportion to its size, but entirely commensurate with its incalculable multitudes. The Herring fishery has the exceeding merit of antiquity, and the distinction that, as the centuries have rolled by, it has grown in popular favour instead of waning, although it has lost its place at the tables of the wealthy, where 'bacon'd' Herring used to be accounted a great dainty. The chronicles of Evesham Abbey of the year 709 made mention of the Herring fishery as being even then established, the Herrings, I suppose, being brought from the Bristol Channel by way of the Severn and Avon into the heart of Worcestershire.

Yarmouth, the Herring metropolis, has been famous for its fishery since the days of Norman William, the shallow sandbanks lining the coasts of Suffolk and Norfolk having ever been a favourite resort of the valuable little fish, and one that, capricious as they often are in their movements, they seldom fail to visit in vast numbers. To-day, although Yarmouth has gradually changed from being one of our principal fishing-ports to the less romantic but far more profitable position of a great favourite seaside resort, during the Herring season it is a scene of the greatest activity, quite an immigration of Scotch lasses, expert at dealing with the Herring in the way of preparing them for curing, taking place.

Yarmouth, however, can in nowise claim a monopoly of the Herring fishery, for all round our coasts, except Cornwall and Devon, the pleasant fish is found in varying numbers according as they feel inclined to visit this, that, or the other place. The reasons for this capriciousness are not at all understood, whether it is a question of food, or gales, or temperature. But the telegraph keeps the smacksmen advised as to the movements of the fish, and no place can be visited 


\section{Dutchmen and Herrings 295}

by them without the prompt arrival of the fishermen in pursuit.

All round the sea coasts of Northern Europe the Herring is to be found in its season, from the North Cape to Ushant, but of all these countries where the Herring is known and loved and caught, Holland may probably claim the pre-eminence in antiquity and importance. There was a time when the fishermen of the Netherlands supplied the whole of Europe with Herrings from their sandbanks, which are a characteristic feature of the Dutch coasts. Nay, Holland itself is just a series of sandbanks wrested from the sea, which is only kept from resuming its ancient sway over the country by unceasing care, and watchfulness over the dykes. Thus the Herrings were, so to speak, at the Dutchmen's back doors, and right profitable advantage did the sturdy Netherlanders take of the fact.

In the early days their method of curing for export was rough and rude in the extreme. They just piled the fish in heaps and sprinkled salt upon them. And the condition of those fish in a week or so must have been horrible. But people were not fastidious then, and disregarded the laws of health pretty much as they listed, being almost entirely ignorant of them, though it must be admitted that the Dutch were far in advance of any other nation in that respect.

But in process of time a great genius arose, William Beukelaer, of a village near Sluys, who discovered that by pickling Herrings in barrels they might be really preserved from decay, be more portable, and incomparably cleaner and more wholesome. It seems to us now but a trifling and very obvious improvement upon the old method, but such as it was it had a most 


\section{The Herring}

mighty influence in the moulding of Europe. For upon that apparently insignificant basis arose the Dutch Republic, which successfully resisted the infernal domination of Spain, and dealt one of the deadliest blows at the truly Satanic Inquisition that it ever received, making it, in fact, possible for Britain to finish the good work so well begun. Alas! that before doing so we should have been compelled to destroy the splendid fisheries and oversea trade built up by the strenuous Dutchmen.

First the Herring, then the whale. These two sea-folk brought great prosperity to Holland, but note well, not a prosperity based upon luck, or accident, or coincidence, but sheer hard work, dogged perseverance, and undaunted courage. Faithful to their first great success, the Dutchmen always spoke of the Herring as the 'great fishery,' of the whale as the 'small,' having reference, of course, to the relative importance of the two industries and not at all to the size of the creatures taken.

Truly the Herring fishery was a great undertaking -in I606, when it was at the height of its prosperity, it gave employment to two hundred thousand men. Three thousand smacks were employed and treble that number of schuyts and galliots were engaged in the transportation of the spoil of the sea. Then came the unhappy quarrel with England arising out of the partisanship of the States General for the Royalist party. Cromwell and his great admiral, Blake, dealt such disastrous blows at the sea business of the Netherlands as practically crippled them. Then, when they were struggling doughtily to recover from their great misfortunes, they found the hardy Northmen already in possession of the bulk of the trade, and to brown all their misfortunes, they fell at last between 


\section{An Immense Industry}

the upper millstone of Napoleon and the nether millstone of England, which completed their ruin. But such a people could not long be kept down, and accordingly towards the end of the first half of the nineteenth century they began to recover again, and have now built up a fine trade once more.

All this time we were too busy fighting and developing in other directions to pay much heed to the Herring fishery, but at last, having destroyed the Dutch fishing fleet, we began to feel the need of establishing a much larger fishery for the supply of our own increasing wants. And this impetus given to the business has lasted until now, the greatest development, however, having shown itself among the Scotch, who boast that their Loch Fyne Herring are the finest in the world.

On the coast of Newfoundland and as far North as Labrador, there is a considerable amount of Herring fishing carried on, the fish being of a larger and fatter kind than are found over here. But the business is so dwarfed by the great cod fishery that we hear very little of it. There is, however, a rather important fishery carried on farther south, off the New England coast, that of the 'Menhaden.' a species of Herring which is so rich in oil as to be hardly eatable. It is caught in immense quantities for the purpose of extracting the oil, which fetches a good price, and the dried fish remaining is used for manure.

But one of the most peculiar facts in connection with the Herring is the persistent way in which one branch of the family, the Pilchard (Clupea pilchardus), remains faithful to the south-western corner of England, the counties of Devon and Cornwall being thus favoured to the almost total exclusion of any other part of the country. In this they differ greatly from the Herring 
proper, which is notable for its fickleness in visiting various places around the coast. Fortunately I have avoided making mention of the unaccountable numbers of the Herring, for great as they are, one must reserve all the superlatives at command for the Pilchard.

I remember hearing from some St. Ives fishermen how one season, when the fish were even more numerous than usual, how it occurred to some enterprising net owners that it would be a good thing to stretch a strong fleet of nets across the narrow entrance to a tiny bay, a mere pond of less than an acre in extent, at high water when it was practically alive with Pilchards. They did so, and when the tide ebbed they were appalled at the magnitude of their haul. They sent word hastily to all the population round about to come and take their fill of the spoil, to farmers that they might bring their waggons and cart off the fish for manure, to everybody, in fact, who could in any way lessen the heap of fish. But in vain. Nothing seemed to make any impression upon it, for there were thousands of tons. And the foolish greed of the originators of this wholesale plan of capture was punished by an epidemic which, begun in that mountain of putrefying fish, devastated the neighbourhood.

Only by remembering that in the ordinary course of the fishery ten thousand hogsheads have been landed in one port in a single day, roughly twenty-five millions of fish, can we imagine what that gigantic haul shut in the little bay must have been. The fish run so thick in the schools that a pitchfork will stand upright in them, as if stuck into a hogshead full. And it is usual when a shoot of nets has been laid round a portion of a school like that for boats to be loaded from the inside of the circle as from a tank, and only take ashore as much at a time as can conveniently be 


\section{The Savoury Pilchard}

dealt with. By this means the fish are kept from spoiling.

Apart from those that are consumed locally, there is not much British trade in the Pilchard. It is too rich for most tastes. So it is salted and packed in hogsheads for the Continental market, whither it is sent after a period of pressure upon the fish in the big casks for the purpose of expressing as much of the oil as possible.

But for some obscure reason, of which I know nothing, it seems impossible to spread the sale of this rich and tasteful little fish farther than its present somewhat restricted distribution. Many attempts have been made to do so, serious and well-managed efforts which deserved success at any rate. Lightly cured and of a bright golden colour, Pilchards in bundles were for some time to be seen on almost every fishmonger's show-boards in poor neighbourhoods. They were not only appetising in appearance, but of really delicious flavour, besides being as cheap as the London workman insists upon having his food, that is to say, cheaper than food can be bought of the same kind and quality in any other city in the world.

But I am afraid that they came into competition with the herring too severely, and so brought down upon themselves, or rather their owners, the enmity of the great herring factors, for I have noticed that for some time past they have hardly been procurable. Or perhaps the people for whose benefit they were intended would not encourage their sale. The poorest classes, of London especially, those that is who work and support themselves, are tremendously conservative, clinging tenaciously to old ways, old styles of food, in a wonderful manner. But if by perseverance some new food is at last brought into their favour its success 


\section{0 \\ The Herring}

is assured, they will rush for it in hundreds of thousands, while at the same time remaining loyal to their old loves. And perhaps some day they will appreciate fresh Pilchards as much as they now do fresh herrings, and bloatered Pilchards also.

A great deal of capital and energy has also been expended in the attempt to utilise the Pilchard as a 'Cornish sardine,' which is retailed at a very modest rate, but has certainly not been able to do any harm by its competition to the sale of sardines at nearly double the price. They are good and very wholesome, the utmost care is taken in their preparation -but even the most careless person would never take them for sardines, the delicacy of flavour, scarcity of bones and succulence of flesh being altogether in favour of the sardine. A much better idea has been that of preparing Pilchards in oil as Pilchards, putting them on the market under their own name and trusting to their own good qualities to make a lucrative sale for them. They can be obtained at nearly all respectable grocers, and I am sure only need a trial to become favourably known.

Whether a largely increased sale for them or for any other fish that can be sold very fresh is likely under the present market conditions of England generally I do not know. But I fear not. It is a thing to be remembered in this free trade country, how coolly, how frequently, the price of necessaries of life is raised, how persistently the cheapening of food is opposed by the dealers in these commodities, and how utterly helpless the consumer is to alter this tyrannical state of affairs. Nowhere is this more marked than in the distribution of fish. But for the costermongers and their energy in clearing away a 'glut' of fish from the market, when by some un- 

. 


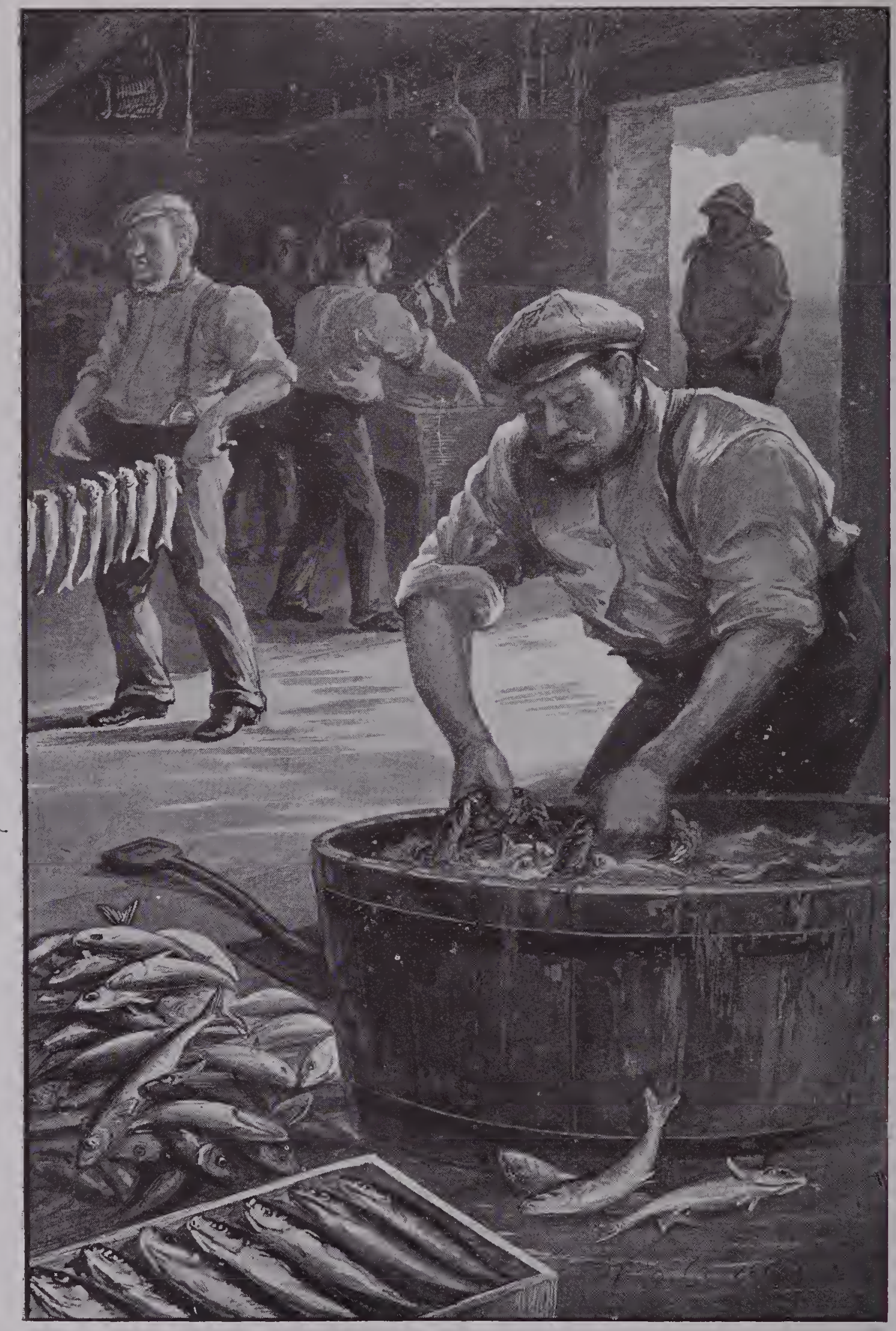

IN THE HERRING CURING HIOUSE. 


\section{The Vulgar Sprat

foreseen hitch in the middle-men's plans such a thing happens, it is not too much to say that most of the very poor would never know the taste of fresh fish at all. But perhaps this is more than enough of the economic side of the Pilchard, which, at any rate, is much beloved in what may be called his native county of Cornwall, however difficult it may be for him to get just appreciation in the rest of England.

Following on after the pilchard in point of size, but almost as universal in their British habitat as the herring, comes the Sprat, dear to Londoners. Indeed, they are the whitebait of the poor, and so well-flavoured that it can scarcely be doubted that but for their amazing numbers and consequent cheapness they would be quite as much in favour with the wealthy as the delicate little fish which used to be sacred to the ministerial end-of-the-session dinners at Greenwich. Very graciously this little herring comes upon the scene immediately after the herring season is over, and in immense numbers.

But it is much to be feared that the catching of them does not afford anything like adequate remuneration to the fishermen. And the demand, though undoubtedly large, is strictly limited. If the quantity brought ashore at all oversteps that limit, this beautiful little fish goes off in its myriads for manure. And I have often seen Sprats being sold in London at one penny for two pounds. Here, at any rate, the complaint against the middle-man keeping the price up can hardly be maintained. But as far as I know it is almost the only fish of which the same thing can be said.

Also the Sprat lends itself most amicably to curing, somewhat after the style of the kippered herring, except that it is not, of course, split open. It is cured 


\section{2}

\section{The Herring}

by smoking, having very little salt added, and is then tied up in little bundles of ten, which are usually sold three for twopence or one halfpenny each. Most delicious and delicate they are in flavour, too, only that they have the fatal plebeian stamp of plenty and cheapness. But even the poor do not, I think, appreciate them as they should. Not nearly as much, for instance, as they do such shell-fish as the periwinkle and the appalling whelk, which is a miracle of toughness and indigestibility.

Following up a theory very largely held that the herring, the Sprat, and the sardine, are one and the same fish, serious attempts have been made to serve Sprats in tins à la sardine. But no one of the slightest discrimination can fail to detect the difference at once. There is no doubt that an enormous number of Sprats are preserved in inferior oil such as cotton-seed oil, and sold as sardines at fourpence to sixpence a tin, sardines of undoubted genuineness costing at the same time one shilling and twopence per tin of the same size, and there is equal certainty that people who have grown fond of fish preserved in oil do eat and enjoy these tinned Sprats in the belief that they are sardines, utterly oblivious of the fact that they are paying from eight to ten times more than they need for the dainty little fish, which when smoked, may safely challenge the whole fish world in point of flavour, but does not take kindly to preservation in oil, as do the sardine and anchovy. But, except for the fact that these Sprats are sold as sardines when they are not, this is nobody's business but the sellers' and the buyers'; I mean, that no one is done any great harm to, and so it is not necessary to interfere. It is perfectly certain, however, that the name 'Sprat' has so low and vulgar a sound that, if these tinned 


\section{Providential Habits}

Sprats were offered for sale as such, no one would be found to purchase them at all.

The habits of the Sprat as far as they can be known are identical with those of the herring. Both feed in their incalculable hosts in the deep water off our coasts, affording in their turn food to a mighty army of larger fish of many species. Then when the time draws near for them to spawn they come shorewards, drawing closer together until they appear like a solid wall of fish many yards thick and hundreds of yards long, all moving by one common impulse towards whatever spawning ground they may happen to be seeking. They have no leaders, and it passes the wit of man to understand why they vary their spawning places: whether it is the weather, the temperature of the sea, or the quantity of food to be found which actuates them. The amazing thing is that every individual of the countless millions feels the same impulse, obeys it at the same moment, and needs no other guide.

For the sake of the humans who depend upon them, it is a wonderfully valuable dispensation of Providence which compels them to seek the surface and the comparatively shallow waters near the shore to spawn, since otherwise it would be perfectly impossible to catch them. No other means could be devised which would be so effectual in garnering this rich harvest of the sea as that universally employed and invented in who knows what dim, far-off age of the world's history.

And yet the method is not, as might be supposed, universally understood. Very briefly it is this : of stout well-tarred twine a net is constructed about twenty feet wide and in one hundred and twenty feet lengths, making up for one boat about two hundred 


\section{The Herring}

fathoins. At the top and bottom are stout ropes, the lower rope being slightly weighted with sheet lead lapped round it in places and the upper buoyed with pieces of cork. The meshes are made just large enough for the herring or Sprat, as the case may be, to get its head through. Then it is caught, for the pectoral fins and swell of the body will not allow it to go any farther, while the opening of the gills prevent it from moving backwards. When the nets are shot, as it is termed, they oppose to the passage of the army of herrings an invisible fence through which it is impossible to pass, but which is, of course, attempted. Presently an enormous number of fish are entrapped by the neck, but so lightly are they held that when the net is hauled into the boat a gentle shake is quite sufficient to dislodge them, and they fall into the boat dead, for the herring dies almost at once upon leaving its native element.

Meeting this invisible barrier throws the school into terrible confusion, and it breaks up, its units, no longer homogeneous in mass, rushing aimlessly hither and thither. A catastrophe has taken place in their world far greater than the swift passage through their mass of a whale with vast jaws widespread swallowing many thousands of them at a gulp, or the incessant incursions of the porpoises and sharks. But the barrier once removed and its goodly load of victims transferred to the boat, they soon re-form again and, obedient to that compelling impulse, resume their steady march towards their objective.

Much to the discomfiture and loss of the fishermen, it does occasionally happen that a whale in pursuit of his prey comes gliding on to where the nets stretch right across his path. As the fishermen can easily see his approach, even on the darkest night, it is an 



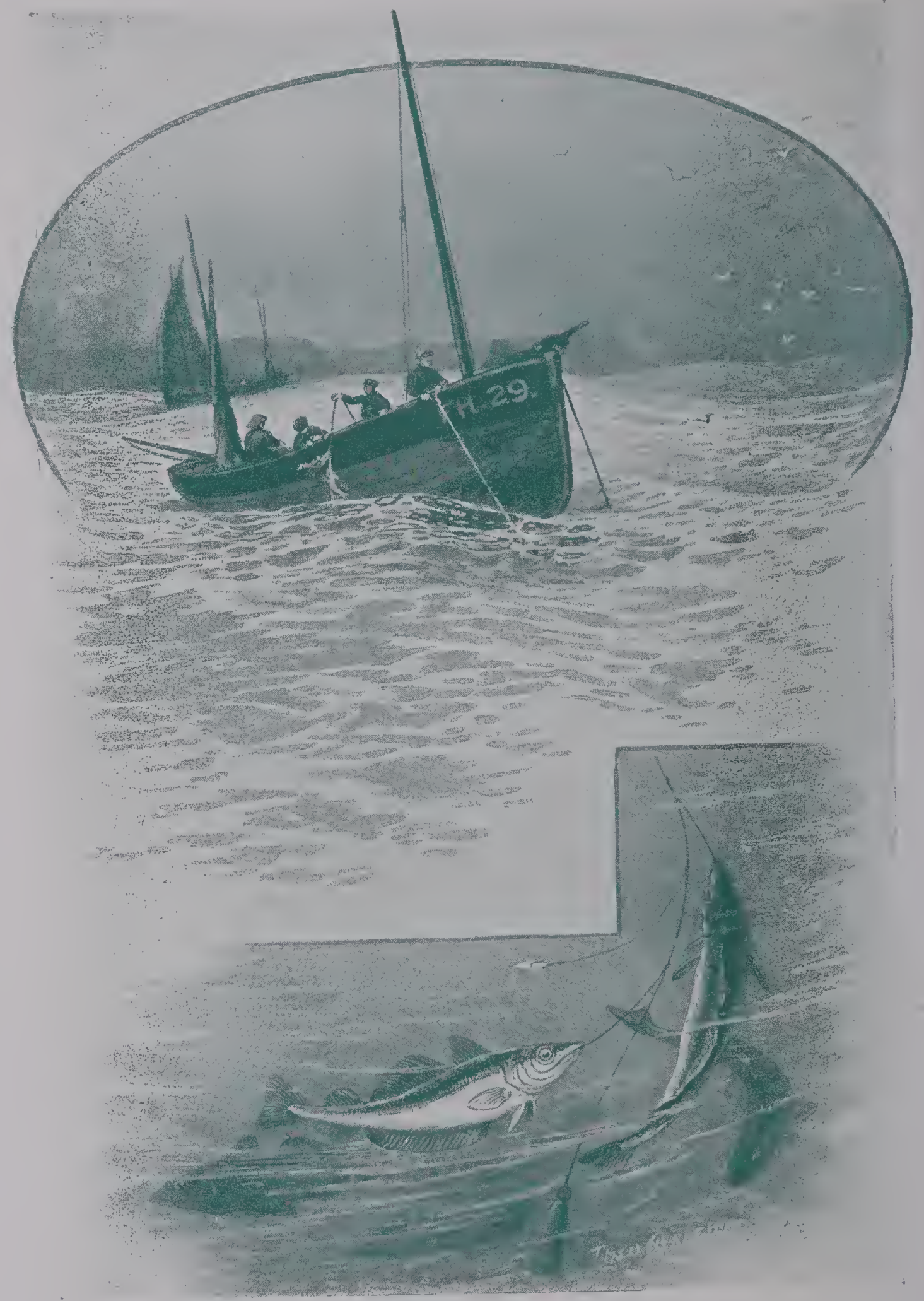

HOW THE WHITING IS CAUGHT.

[To face t. 305 . 


\section{Trials of Herring Fishers 305}

anxious time for them, and all manner of strange devices are resorted to for the purpose of turning him from his course. For should he pass through the nets, while he would hardly feel them, it would be nothing short of a disaster for the poor men earning their hard and precarious livelihood. It might convert a fairly prosperous season into one in which a dead loss was made, for those nets are costly, and a whale can easily carry away a whole flight.

Scarcely less destructive are the sharks and dogfish and porpoises, all of which are far too strong, ravenous, and reckless, to be safely hindered by the envelopment of herring nets. Also it is not an unknown thing for a ship to blunder through the nets, and cause much damage, so that, apart altogether from the chances of severe autumnal weather, the herring fisherman's life is a very anxious one, and he deserves all the efforts that are being made by good people ashore for the furtherance of his spiritual and material welfare. These fishermen are, taking them all round, a splendid race of men, and entirely worthy of our deepest regard.

The tiny species of herring known as Whitebait (Clupea alba) is taken in small bag nets just beneath the surface of the water in the estuaries of our rivers, principally in the Thames, in spite of the pollution which has robbed the beautiful river of most of its fish, even in the high reaches. But the tiny wanderers only come in with the flood-tide, getting out again, those that are not caught, before the poisonous matter brought down by the ebb has had time to overtake them. The catching of them is a very small but fairly lucrative industry, there being always a brisk demand for them at high prices, since they are what may be termed a fashionable fish. Yet, as I bavs 


\section{6 \\ The Herring}

said before, there can be scarcely any question but that the vulgar Sprat is of much better flavour, although it must be admitted that the Sprat is a trifle rich for delicate stomachs to deal with. There is little doubt but that other young fry are frequently brought to market and sold as Whitebait, or that they are just as good, no one but an expert ichthyologist being able to tell the difference between them and the Whitebait. So that the substitution may be quite innocent, and in any case does not matter.

The Sardine, while a veritable herring, is a very well-marked variety, having distinct qualities of its own, and keeping rigidly away from the shores of Britain. It is caught at various places along the coasts of France westward from the bay in which are the Channel Islands, but the chief fishing port is L'Orient on the northern shore of the Bay of Biscay in Brittany.

But of late the Sardine fishery has fallen upon evil days. The natural enemies of the little fish, such as whales and porpoises, have increased so greatly that the shoals no longer come near enough to shore to be caught; indeed, there do not seem to be any shoals of Sardines at all, and the poor Breton fishermen are in such dire straits that public help has been asked and obtained for them. And a paternal government has, at the request of the fishermen, granted the use of torpedo boats to hunt and destroy the porpoises, in the hope that thus will the drain upon the supply of Sardines be stopped.

But it seems very doubtful indeed whether such measures are of the slightest use. Except for some terrible submarine calamity, such as a sudden lowering of the sea temperature, or a volcano suddenly becoming active, the numbers of such a fish as the Sardine would 


\section{A Sardine Famine}

not be affected. The natural checks placed upon their increase in the sea by the Creator will never do more than they should do, when unmolested by man. It is only when man thrusts his hands into Nature's work that any great unbalancing of natural resources takes place. The Sardines have just moved on a little, that is all, and will, I hope, be as plentiful as ever round the Breton shores again soon.

The dainty little fish is also found in the Mediterranean on the coast of Africa and about the islands of Corsica and Sardinia, but in these localities is more a matter of local consumption than of preparation for export. This seems strange too, seeing that from the latter island it takes its name, and its plenty there is beyond question. But the Bretons have made the Sardine fishery peculiarly their own, and nothing apparently but a continuance of the present dearth can take from them their premier position as the world's purveyors of the finest brands.

The Anchovy is also a Mediterranean fish of worldwide reputation as an appetiser, its piquant flavour and the rather large quantity of salt considered necessary to its preservation making it a much desired adjunct to other fish in the shape of sauce. Its peculiarly coloured flesh, too, helps it for this purpose, the dark red of the Anchovy contrasting well with the white flesh of cod, turbot, etc. In this respect it differs widely from all of its congeners, and except for the assurance of those who have made fish their social study, I should hesitate to accept the statement that it belongs to the herring family at all. In any case it is but a distant relation, for the prefix Clupea is dropped, and a totally dissimilar one, Engraulis, is given. The principal fisheries are along the Riviera, where the fish are pickled in tiny barrels and sent else- 


\section{The Herring}

where to be made into sauce or paste, or eaten au naturel as the Dutch eat the pickled Herring. But the fish frequents the whole of the adjacent coasts eastward, being caught all down the Italian shore as far as Sicily as well as on the African shore.

Of the Large Herring frequenting the inclement shores of Labrador, alluded to in the early part of this chapter, there is very little to say, except that, like the Menhaden, they are far too full of oil to be relished by us, even if it were worth while to send them over, which it emphatically is not. They are, however, in great demand in America in their pickled or salt condition, and are to be found all over the interior of the United States and Canada. Scattered members of the herring family are found in many parts of the world, none calling for comment but the Freshwater Herring of some Australian rivers. Many of these I have caught with a hook and line from the wharves on the Clarence River, and do not remember that they presented any essential difference from the herring caught in the British seas. But then I did not attach any importance to the fact that I was catching them in fresh water, a point which should have claimed my attention even at that early age.

I have left to the last the mighty and majestic Tarpon, beloved of wealthy anglers and frequenting the shores of the Gulf of Mexico and adjacent islands. $\mathrm{He}$ is undoubtedly a herring! But such a herring! Specimens have been caught weighing two hundred pounds, and the sport of landing such a monster as that with an ordinary salmon rod and line calls for the highest skill, strength, and patience on the part of the angler. It is such a splendid game fish too, leaping high into the air like a huge bar of silver when hooked, and endeavouring to shake the galling hook 


\section{The Majestic Tarpon}

out of its mouth. In this it very often succeeds, much to the chagrin of the fisherman, whose utmost skill is powerless to prevent such an accident unless by great good fortune the hook should have penetrated the only vulnerable part of the jaw.

One night in Barbadoes, fishing with ordinary tackle, I hooked Tarpon over twenty times, and lost them before I had gathered in half a dozen fathoms of the line. For whenever they sprang into the air, which they did as soon as they felt the hook, they leaped towards the boat at the same time, and my hooks being of a very inferior type and not at all like the keen slender hooks sold for Tarpon-fishing, they would not hold, especially as I could not keep a strain on the line. But at last I did succeed in catching one (he fell off the hook the moment he entered the boat), and immediately examining his mouth I found it apparently entirely devoid of any place where a hook could enter except the edge of the lip. It seemed to be all solid, polished bone. I thought I had never seen a more beautiful fish. Its eyes were very large and full, and its scales, each as big as a crown piece, were just like planished plates of mother of pearl. Of the quality of its flesh I can say nothing, as I sold it, and so did not assist at the eating of my prize. 


\section{CHAPTER XXII}

\section{THE BARRACOUTA}

I $\mathrm{N}$ dealing with this fish, the last upon my list, I have one great advantage: knowing him very well, indeed personally, I am not hampered with what I may call museum details. Strangely enough, the Barracouta, in spite of the large extent of his range, his great numbers, usefulness as a food-fish, and other strongly marked qualities, has been much neglected by ichthyologists, Messrs. Goode and Bean's monumental work, for instance, having no mention of him. Lydekker mentions the name, spelling it 'Barracouda,' as being indifferently applied to the genera Thyrsites and Sphyroena. But that does not shed a dazzling light upon the habits of a most interesting deep-sea fish, and one that is found in nearly all tropical and temperate waters around the world. I should like though to say at the outset that, in my experience, the Barracouta of the West Indies differs in very important respects from the fish known by that name around the South African coast and in Australasia ; yet the habits and contour of the two are so exactly similar that I am convinced they are very closely related, and the difference probably due to climate and habitat.

My first acquaintance with the Barracouta was made in the small reef-protected harbour of Falmouth, Jamaica. A native fisherman brought one on board for sale, and the steward, after some little haggling, 


\section{A Dangerous Neighbour 3II}

bought it and hung it up beneath the boat on the skids. Being at that time of an age when inquisitiveness is the normal frame of mind, i.e. about thirteen, I soon found an opportunity of examining it. It was about three feet long with scarcely any bulge to its body, which was about eight inches wide and five inches thick, tapering off very little to the tail. Its head was very much like a pike's, with a lower jaw considerably prolonged beyond the upper one, an enormous gape and cruel-looking canine teeth. Indeed, but that it was more symmetrical, it reminded me very much of the head of a crocodile. The eyes were large and well situated for seeing in every direction, being set prominently, one on either side of the widest part of the wedge-shaped head. The fins were rather small for the size of the fish, all except the caudal or tail-fin, which was large, fleshy and lightly forked, having a very wide area of propelling surface. The body was covered with medium-sized scales, which were easily detached, showing in a marked degree its difference from the mackerel family, whose scales are few and most firmly attached to their bodies. Its colours were simple, a dirty brownish black above and livid white below, the two meeting at the lateral line. It was long afterwards when I first saw a hake, a common fish around our south-western coasts, and I was immediately struck by the great resemblance between it and a Barracouta-so great that I feel sure they must belong to the same family, although I do not believe the hake has anything like the ferocious character of his great southern congener.

While I stood studying the contour of this, to me, new and strange fish, the cook, an elderly negro belonging to the island, sauntered up, and after handling the fish, began in an impartial sort of way 


\section{$3 \mathrm{I} 2$ \\ The Barracouta}

to tell me anecdotes about the Barracouta. I regret exceedingly that I am unable to reproduce them here in detail. I can only say that, if true, and the narrator evidently believed them to be so, they stamped the Barracouta with a malignancy of character in its relations to man compared with which that of the shark is personified amiability. It must suffice to say that, according to cook, the vicinity of a Barracouta to a swimmer meant death, death by lingering torture, since the terrible fish only took one bite, but that a diabolically efficient one. No wonder, believing what they did, that the negroes should have called the Barracouta the 'devil-fish,' one among the many denizens of the deep sea to which this grisly name has been given.

A few days later I had an opportunity of seeing how firm a hold this belief had upon the darkies. By accident a pair of can-hooks had been dropped overboard, and although the water was forty feet deep, such was its transparency that they could plainly be seen resting upon the smooth white sand. There were several sharks prowling around as usual, but the offer of a shilling to whoever would dive for those can-hooks was quite sufficient to bring forward instantly half-a-dozen eager candidates, who cared no more for the presence of a shark than they did for a sprat. One by one they went overboard, making first a bit of a splashing to keep the sharks at a respectful distance, and then swimming down to the bottom.

But the can-hooks proved too heavy to lift to the surface, although several divers tried, and at last a man was going down with a hook on the hand lead-line to attach to the chain of the can-hooks when suddenly a cry of 'Couter,' 'Couter' was raised. There were at the time eight negroes in the water gambolling about and 


\section{My First Barracouta}

taking as little heed of the fact that there were many sharks in the vicinity as of one another. But at that cry there was a frantic rush to get out of the water. Demented, they tore at one another for the possession of ropes that were flung over, and for a few moments it looked as if a tragedy were imminent. But, fortunately, all got safely on board, although their demoralised, panic-stricken condition was painful to witness. And their discussion of the situation afterwards savoured more of the proceedings of a bevy of Bedlamites than anything else.

The vessel was wrecked on leaving the port for home, coming to grief about two miles outside the harbour, and consequently I had an opportunity of studying shore life among those cheery amiable darkies. One day four stalwart ebon friends of mine foregathered on the beach, and I, coming up with them, learned that they were going Barracouta fishing. I asked if I might come too, and was immediately made welcome, nay more, I was allowed to sit in the stern of the canoe and hold the line, a stout cord about sixty yards long with one two-inch hook baited with a whole fish about six inches long, of what kind I do not now remember. I sat upon the gunwale right aft and held the line, which had been allowed to run out about half its length, while my four friends plied their paddles with all their might, making the canoe fly through the water, the object being to make the bait appear alive.

It was most exhilarating for me, although the exertion under that blazing sun must have been most exhausting to my friends. For some time no fish came, as we careered to and fro across the bay, and presently taking a couple of turns round my hand I looked forward at my energetic paddlemen. Suddenly 


\section{I4 The Barracouta}

I described a confused sort of somersault, and struck the water far astern of the canoe. For me the rest of the episode, until I found myself again in the canoe, vomiting gallons of sea-water, as it seemed, was one hurly-burly of noise and rushing waters. I was told that in their haste to rescue me the men had capsized the canoe, which was but a trifle to these amphibia, but had delayed things a bit. However, as soon as I began to take an interest in mundane matters again I felt considerable pride (although none of the credit was mine) in seeing a Barracouta nearly five feet long lying in the bottom of the canoe. And I learned with deep satisfaction that evening that he had made $4 s .6 d$. for my fishermen, who had peddled him around the town. From thenceforward, however, I was rigidly debarred any participation in the chase of the Barracouta, earnestly as I pleaded for another opportunity.

My next passage was to Kingston in a small schooner, when a great deal depended upon our being able to catch a Barracouta, for our provisions ran out, and we were becalmed a long way off the land. But whether it was owing to the light wind not giving the schooner way enough through the water, or our clumsy attempts to lure them, I know not, never a Barracouta could we get hold of, although we saw many swimming in their stealthy manner round and round our vessel.

The only fish we caught was a shark, which was immediately cut up and cooked. And although my hunger was fierce, I have a vivid recollection of the nauseating quality of that food-I can recall its horrible flavour now, although it is thirty-three years ago since I reluctantly ate it. After we had been in to Savanna le Mar and replenished our stock of provisions, and consequently had no need of fish, we caught several fairly large specimens of Barracouta, by trailing 


\section{Eastern Specimens}

a line astern when the schooner was running with a fresh breeze.

From Kingston I went to Port au Prince in Hayti, and in that wonderful harbour watched the sharks and the Barracouta prowling ravenously about, taking never-ending toll, the former of all that fell from the ship, the latter of all sorts of fish. It was like watching a continual battle, and, indeed, the warfare of the submarine world is unending, whether we can see it or not.

Then I returned home, and after a season in Liverpool sailed for the East Indies in a ship where my fishing experiences were widely extended. The strangest of them was in the Indian Ocean some distance out of sight of Mauritius, to the eastward of it. The mate had been unsuccessfully trolling for dolphin with a piece of red bunting, the ship sailing about four knots an hour. And to my great delight he permitted me to attend to his line while he went to 'take the sun.' I sat on the wheel grating holding the line, as happy as I could be, and fully expecting to succeed where the mate had failed (I had done so before), but without any success until eight bells, when the mate went below to work up the ship's position. He had hardly disappeared when I felt a tremendous tug at the line, and springing to my feet I hauled with all my might. But my surprise was too great for words, when, on landing my fish, I found it to be a goodly Barracouta of about ten pounds' weight, and identical in appearance with those I had been acquainted with in the West Indies.

Fearful lest I should be superseded in my pleasant task, I unhooked my prize as quietly as possible, got the relieved man from the wheel to take it forward, and resumed my fishing, landing two othors in quick 


\section{The Barracouta}

succession. When the mate returned to his line he was astounded to see what kind of fish I had caught, having no idea that they were a deep-sea fish. Much to his chagrin no more were caught, either then or afterwards. Not only so, but that was the only time I have ever seen or heard of them being taken far at sea. But, of course, I do not suppose ours was a unique case. They must be a pelagic deep-sea fish, only scarce in number, and consequently seldom seen. After all, the opportunities that ordinary sailors have in sailing ships (they have none in steamers) of becoming acquainted with deep-sea fish are very scanty. And if a man has no liking for natural history study he may be like a man who sailed with us in the "Cachalot' the whole voyage, and as he asserted afterwards, owing to his being short-sighted, never saw a whale!

After that well-remembered encounter with the Barracouta in the Indian Ocean, it was eighteen months before I saw another. The next time was while I was lamp-trimmer in a small steamer called the "Helen McGregor,' running between Sydney, N.S.W., and Grafton, Clarence River. I had been told by a fellow 'lamps' who was in another ship of the same company, the 'New England,' that if I got a long stout line and good hooks I might get fish on the coast sometimes by trolling, especially between the North and South Solitary Islands. Always enthusiastic about fishing, I obtained the requisite tackle at the first opportunity, although I felt very sceptical as to any fish coming near enough to the wake of our screw.

However, that next passage, having secreted a little white and scarlet bunting from the store in Sydney I mounted the poop when the vessel was off Port Stephens just after daybreak one morning and started. To my great satisfaction after only a few minutes' 


\section{Australian 'Couters}

waiting I caught a fine fish, not a Barracouta, but a much more elegant and beautiful creature, called trivially a 'yellow tail,' from the bright gold colour of its fins and tail. I was delighted at my success, and as soon as I had disposed of my prize to the cook (strangely I never cared what became of my fish after I had caught them and gloated over them for a little while), I tried again, shortly afterwards capturing a fine Barracouta.

But now I was sorely puzzled. There was between this and all other Barracouta I had ever seen one radical difference, it was practically scaleless, at least as much so as a mackerel, while the others had been all completely clad in scales. In every other respect, as far as I could see or remember, they were identical. This, however, was so great a difference that I could only account for it by supposing that they were a different species. Certainly they were both known as Barracouta, and no one has seemed to notice that there was any difference.

While I remained in that small steamer I caught many, caught them right up to the turbulent edge of the Clarence River Bar, and I have no doubt might have done so in the salt estuary of the river itself, but that once inside the Bar I was always too busy with other matters for fishing. I noticed, or I thought I did, that these naked Barracouta were finer-flavoured than the West Indian variety, but that may have been fancy.

Then I left the Northern Australian trade and went south, where, though I doubt not Barracouta were plentiful, especially between Wilson's Promontory and Queenscliff, Port Philip Heads, I was not allowed to fish over the taffrail, and was compelled to limit my sport to ordinary bottom fishing while still in 


\section{I 8 The Barracouta}

Hobson's Bay or Auckland Harbour, the latter the most prolific place for fishing in that I have ever known.

But getting tired of good living, good pay, and light work, I shipped for England via Burmah, and having put into Port Elizabeth on the way home, we coasted round Cape Colony, at no great distance from the land all the way. And for an ordinary merchantship we caught a surprising number of Barracouta, 'Snoek,' as they are called locally, which I found were naked of scales like those of Australia. This was very strange to me, as those caught in the Indian Ocean off Mauritius were identical, as far as I could see, with the West Indian variety, certainly in point of scales they were.

These South African Barracouta, or Snoek, were tremendously voracious. I have known them to snap at the bare hook, and I have little doubt but that they are responsible for the frequent losses of patent log-propellers, the small four-bladed fan that revolves on a patent log, faster or slower according to the speed of the vessel behind which it is towed, and registers the number of miles travelled on dials.

My next experience of Barracouta was in the Cachalot,' where, indeed, I made the acquaintance of many new kinds of fish, and vastly enjoyed the pleasure of noting their habits, apart altogether from the joy of making many a good meal when without them we should have gone hungry. On the coast of New Zealand, the Maories taught us a novel plan of catching Barracouta, but only possible to any extent where the fish were as plentiful as they were there. In no other place have I seen the Barracouta swim in shoals of hundreds of thousands, almost as closely packed as mackerel. But then I do not believe that there is any sea in the world so full of fish as that 


\section{Maori Fishing}

which washes the shores and fills the harbours of New Zealand, the beautiful Britain of the South.

All around the coasts of the Middle and South Islands, according to the season of the year, the Barracouta swarm, in great schools as I have said, and the orthodox method of entrapping them, invented by the Maories, is as follows:- Take a stout rod, say eight to ten feet in length, or rather a pole, fairly rigid and tough, but not too heavy. To the end of it secure a piece of strong fishing line five or six feet in length. To the free end of this line attach a lure made as follows: A piece of red pine (rimu) four inches long, one inch wide and half an inch thick, is scraped smooth and bright so that it will glow crimson when wet. Through one end of it is driven a two-inch nail, which is carefully bent upward and filed sharp. Then this lure is fastened to the line in such a manner that, in case of the splitting of the wood, the fish shall not be lost. Now the boat, in which two fishermen sit to windward facing forward, is sailed briskly to and fro, the fishermen meanwhile whipping the water occasionally until a Barracouta snaps at the bait, and with a dexterous swing is flung into the boat where, as there is no barb on the hook, he immediately falls off. At the same time the peak halyards are let go, so that the boat's way is deadened and the fishermen ply their poles energetically.

If they have struck a school, the fish rise and fall into the boat with a rhythmical regularity, every sweep of the bait into the water securing its fish. So rapid is the process, that I have seen thirty dozen fine fish, none under six or seven pounds in weight, shipped in an hour, and but for the fact that the fishermen's arms refused duty and imperatively required a little rest there was no reason why this wholesale 


\section{0}

\section{The Barracouta}

capture should not have gone on. Before, however, the wearied arms had rested sufficiently the school had moved off, nor were any more caught that day. But as the fishermen sold them to curers at an all-round price of eighteenpence per dozen, the catch, forty-five shillings worth, could not be called a bad afternoon's work. We, however, found our whaleboat scarcely handy enough for this fishing, and, moreover, as bottom fishing was so good, and the fish caught in that way were much superior to the Barracouta, we did not trouble them very much.

As with the dolphin, I discovered that after all it was not absolutely necessary to have a moving bait in order to catch Barracouta. It so happened that, during our stay in Stewart's Island (Port William) I was made night watchman, and it was my pleasant pastime every morning to watch for the first breaking of day, and begin fishing. While it was yet dark not a nibble would be felt, then as the first tender streamers of colour spread over the heavens, a stray tug or so would be felt, and by the time the sun himself appeared fish could be hauled up at a tremendous rate.

One morning, for some reason unknown to me, the fish were slow at beginning to bite, and I determined to let them have plenty of time. So, leaning far over the taffrail, looking down into the limpid depths, I saw several Barracouta stealing along. For several minutes I watched their stealthy movements with great interest, until suddenly I saw one of them swim to a piece of fish I had dropped overboard and swallow it. I was much surprised, but immediately reasoned that as he would swallow a still morsel, there should be no reason why he would not take a quiet bait with a hook in it. So I hastened and got a strip of fish, put it on a hook, and let it drift slowly astern with the 


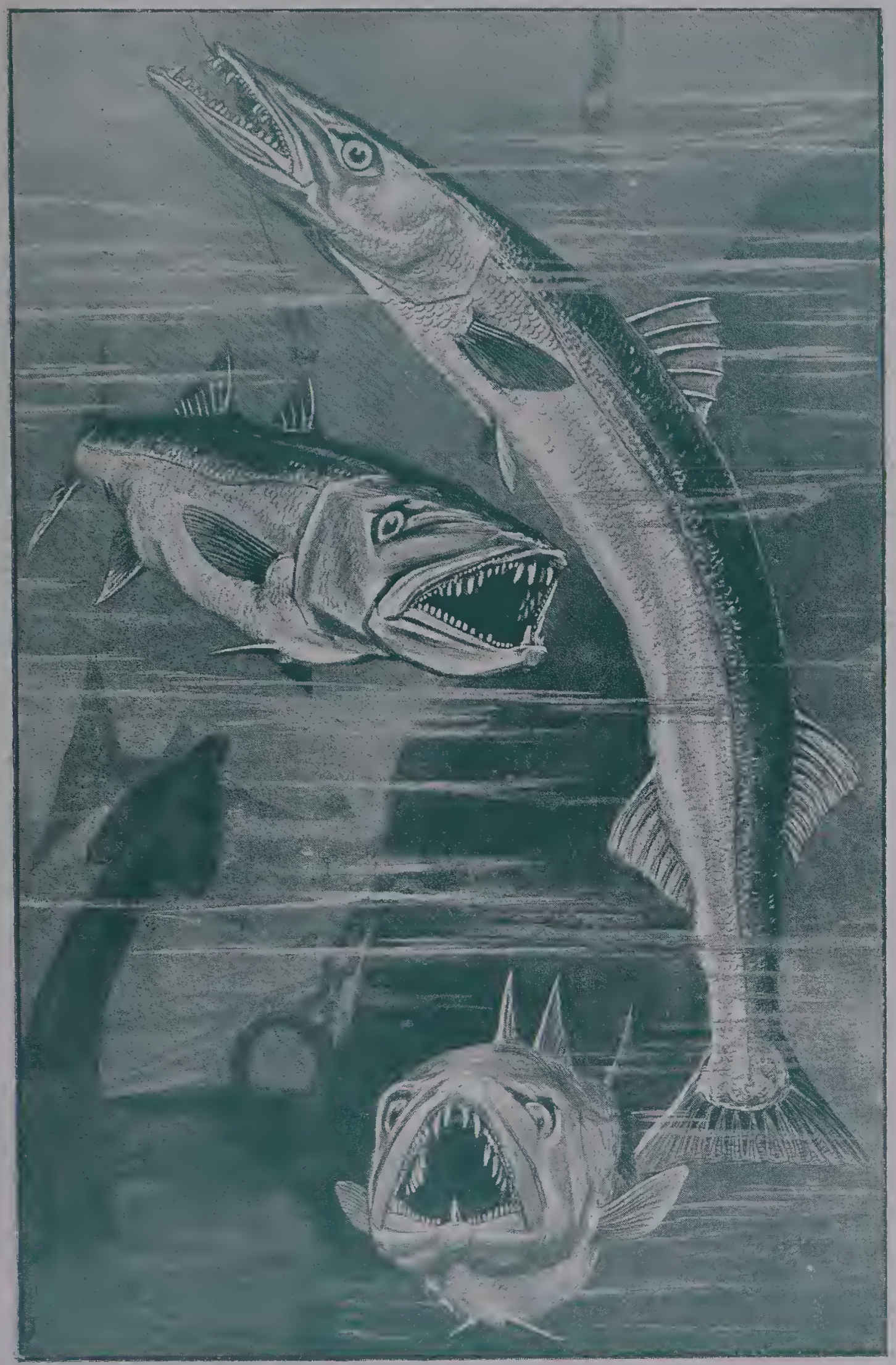

BARRACOUTA.

[To face $p .320$. 



\section{Love's Labour Lost}

little ebb that was gliding past us. In very heisurely fashion one of the fish swam to it, smelt it, tasted it, but when I struck he opened his mouth and I pulled the bait out. Chagrined, but still hopeful, I slacked away again with the same result three times. Then I thought I would let him swallow it, and I waited to see if he would do so. But no, he waited quite two or three minutes to see, apparently, whether I would pull it out of his mouth again. Finding that I did not, he turned round to swim away, and I had him. And by pursuing the same tactics I secured the whole party in less than an hour, eleven of them, all over tan pounds weight each.

While in New Zealand I heard of an exploit on the part of the Barracouta which filled me with sympathy for the persons affected by it. It gives one a very fair idea of the rapacity of these fish, and also of the numerous hindrances with which public-spirited individuals have often to contend in their efforts to do good to their fellow-men generally. For very many years it had been the object of keen desire on the part of enthusiastic pisciculturists to introduce the salmon and trout to the beautiful rivers of New Zealand. Strangely enough, while the engirdling seas of those lovely islands produce such a variety and bountiful supply of fish as could be excelled by no other waters in the world, the streams, eminently fitted to be the homes of such valuable food fishes as salmon and trout, were almost destitute of fish, at any rate there were none worth taking any account of, either for sport or food. So, at very great cost and with an immense amount of care, quantities of salmon and trout ova were shipped from home and brought to New Zealand.

In these days of swift colonial-going steamships 


\section{2 \\ The Barracouta}

universally fitted with refrigerators, the safe carriage of ova scientifically packed in trays of wet moss to the Antipodes is a comparatively easy matter, but in the days of which I write, because of the difficulty of keeping the ova at a uniformly low temperature, not so low as to kill the life-germs, and not so high as to hatch out the fry prematurely, it was no uncommon thing for a whole consignment of many hundreds of thousands of ova to arrive in New Zealand or Australia putrefied. And in any case the consignees were overjoyed if they were able to place in colonial waters ten per cent. of the living ova which had been despatched to them.

Then came the long and patient development of the ova into fry and of the fry into mature fish, a work which could only be carried out successfully by the aid of an intense devotion to, and perfect knowledge of, the business. Such a work had been successfully carried out in the upper reaches of the pretty little river Clutha in Otago. Step by step the embryo salmon had progressed until they had reached, a goodly company of them, the 'parr' stage of their career. Then, following their natural instincts, they journeyed towards the sea, and in due course reached the estuary of the river, which was guarded by a bar, as indeed are most if not all the rivers of New Zealand.

Gaily the juvenile salmon disported themselves in the salt water before making their exit into the vast Pacific smiling without. Then there crossed the bar into the river a school of Barracouta, their long lithe bodies darting hither and thither in quest of prey. They met the young salmon, and, oh the pity of it, in a. few minutes not a solitary parr was left to reward the patient watchers up the river with the sight of a full-fed young salmon returning to his 


\section{Not Knowable at Home 323}

birthplace from the fattening sea. The destruction was complete, almost instantaneous, and was indeed a heavy blow to the high hopes that had been raised. Of course the Barracouta were not at all to blame. They did but obey their predatory instincts, but it certainly was most unfortunate that they should have fallen in with so helpless and withal so valuable a company of young fish, when there were myriads of others in the sea just as pleasant to their taste, and that would never have been missed by anybody.

Of the life history of the Barracouta there is little to tell, for the usual reason-utter inability to get at the facts. But there is considerable ground for believing that in Australasia and South Africa at least, the scaleless variety follow much the same routine of domestic arrangements as do the mackerel at home. Only of course in vastly reduced numbers. For it must not be lost sight of that so voracious is the Barracouta, and to such an imposing size does he grow, that his numbers must be kept down, or he would speedily depopulate the seas which are his favourite resort. Compared with the dolphin, bonito, and albacore, I should not call the Barracouta a swift fish. I consider him, for instance, no match for the flying-fish in point of speed, and I think if he were driven to feed upon flying-fish alone, his numbers would speedily dwindle. But there is always to be found in the ocean for such fish as the Barracouta a never-failing supply of squid, and upon these unnandsome but most useful molluscs the Barracouta of the deep sea must largely depend.

Those which we caught in the Indian Ocean had their maws fairly full, but not of flying-fish. They were small fish about the size of a sprat, but evidently belonging to some variety of the mackerel tribe, and 


\section{The Barracouta}

squid. Evidently our visitors had been in no danger of starving. But that is perhaps a superfluous observation, since it would be hard to point out any fish that is, so vast and universal is the provision made by the Creator for their supply. Along the South African coast and in its spacious harbours, the Barracouta revels in an infinite abundance of food, supplying himself in the enormous quantites of his own young fry the needs of others. And incidentally feeding himself of course, since like all other deep-sea fish, except the shark, it makes not the slightest difference to him which he eats, his own young, or another's.

The Barracouta of the West Indies and the Gulf of Mexico, like the hake of our own coasts, is a comparatively scanty species. Not only is he distinctly different from the Southern Barracouta by reason of his armour of scales but also in his habits and numbers. Like the shark he is an apparently morose, solitary fish. Very seldom indeed are two seen together, as if they could not bear to share any spoil, needing all they can obtain for their own capacious stomachs. And it is abundantly evident that they do not breed in such numbers either, since shoals of them at any age are never seen. Also the great size to which they attain is not even approached by the scaleless Barracouta, which from a comparison of their habits is just what might reasonably be expected. Like restless phantoms they roam those beautiful seas, bringing fear and destruction with them both for their own kind and man. But whether the terror in which they are held by the latter has any foundation in fact I have been quite unable to learn.

There are several varieties of Barracouta inhabiting the deep sea, that is to say, living at very considerable depths, but naturally they are seldom seen. Such 


\section{Good-bye to the Fish}

specimens as there are to be found in museums present all the ferocious characteristics of the West India variety, but in none is this more marked than in a species to which the appellation of Thyrsitops violaceus has been given by the American ichthyologists, Drs. Goode and Bean. The type-specimen, however, was caught as far north as the Le Have Bank, off the New England coast, at a depth of one hundred and twenty-five fathoms, which goes to show that the range of this fish is quite as extensive as that of the mackerel, with which, indeed, it is said by some naturalists to be allied. And with this brief allusion to the deep-sea varieties of the Barracouta we will bid the whole predatory family farewell.

With this chapter I conclude my sketches of deepsea fish. Not, as it will be at once observed, because of the exhaustion of the subject, but because of the limitations of space. There are a number of other fish inhabiting the deep sea with which, when they have ventured near the surface or the shore, I have had the pleasure of acquaintance. Chief among them, in my estimation, is the magnificent Halibut or gigantic flat-fish, which inhabits the North Atlantic and has been caught at the immense depth of two thousand five hundred feet. There are few more satisfactory sensations at sea than that of finding one of these splendid succulent fish on one's line, and after a quarter of an hour's most serious toil bringing the great buckler-like body, despite its dogged pulling against you, to the surface and transferring it to the ship.

These are the events from which the amateur fisherman reckons. How far down in the ocean's valleys the flat fishes really wander no one knows with any degree of certainty-that they have been 


\section{The Barracouta}

brought up in the trawl from immense depths is well known. And not outré forms either, like the majority of the deep-down fish, but familiar flat fish such as soles and flounders. It would seem as if the peculiar shape exactly fitted them for the strange conditions of pressure and the necessity for concealment which certainly are characteristic of profound ocean depths. But it is not to be expected that, however valuable as food the fish may be, any fishery can be profitably carried on which necessitates the working of the gear at such great depths. It is altogether too tedious and expensive to be profitable. Therefore the inhabitants of ocean's profundities are likely to remain undisturbed by man until the end of things, although it be unsafe to prophesy.

I conclude my remarks on fish by a short account of an extraordinary day's sport I once had on the top of a mountain (a submerged one, of course) in the middle of the South Pacific, as showing how colonies of fish are formed in apparently the most unlikely oases, if one may call them so, of ocean. This particular place was well to the north of New Zealand, and somewhere in the deepest part yet discovered of the ocean. I do not know its exact position, but I heard the skipper say that it was part of a mountain range to which the Himalayas must yield place for height, and so I suppose it must have been part of the Kermadec Group.

One afternoon, as we sailed gently along before a very light breeze, we suddenly noticed a change in the colour of the water, an infallible sign of shallowing or of a shoal of fish. And as we entered upon the discoloured area of sea, which came so abruptly that the edge of the deep blue was very plainly marked, the wind died away to a flat calm. The deep-sea 


\section{A Glorious Haul}

lead was cast and gave us sixty-five fathoms, sand and shell bottom. The skipper, being a great fisherman, produced a line, and baiting the hooks with a piece of fresh beef (we were only three days out from Auckland) dropped them overboard. The moment it touched bottom he began to haul up in the greatest state of excitement, calling at the same time for any and everybody who had any suitable fishing tackle to get to work fishing. At which there was a great rush, intensified when the skipper pantingly hauled on board two magnificent fish of a kind I have never seen before or since. They were like a glorified perch, superbly coloured and weighing over twenty pounds each. The mate, who had his line down next, exultingly hauled up a pair of Kauwhai, the huge New Zealand mullet, of about ten pounds each. And then all hands except two joined in the fun.

Such a variety of fish I never saw at one time. There were all the well-known New Zealand favourites except the barracouta and the rock cod. Snapper, cavalle, groper, the last a monster with a mouth like the opening of a coal sack, but in all other respects like a huge cod, except that he had big scales and a cod has small ones. Yellow-tail there were and trumpeter, and at least as many more species of whose names I have not the least idea. We were becalmed for about three hours and we caught at least ten hundredweight of fish in a shallow area of certainly not more than a square mile in extent, which was the summit of a mountain that rose almost sheer from the sea bed for over thirty thousand feet.

The event was a fruitful topic of conversation among us all the rest of that voyage, for none of us had ever known of the like before, and we could not 


\section{8}

\section{The Barracouta}

help wondering and wondering how so vast a number of so many different kinds of fish could have gathered in that lonely spot of shallow ocean in the midst of those mighty depths. 



\section{CHAPTER XXIII}

\section{THE ALBATROSS}

$\mathrm{NO}$ bird that flies is more rightfully entitled to the proud name of King of theSea Air than is the beautiful subject of the present story. Nor are there any of the inhabitants of the air whose home is about the raging billows to whom more mystery, more poetical personality, can be attached than the Albatross. There is something about him which differentiates him from all other sea birds, yes, from all other birds that fly. Principally because, in spite of his great size, he is at home only on the wing, and does not seem to require rest. In this latter particular he is even surpassed by the tiny stormy petrel, but one can hardly compare the little untiring flutterer that skips so blithely from crest to crest of the waves with the great calm bird that hovers majestically in mid-air, needing not to give one single flap of his wide-spreading wings in order to maintain his position against the utmost force of the storm.

Nothing can be better calculated to impress the beholder with the marvellous wisdom of the Creator in fitting His creatures for their position in the world than the sight of an Albatross bearing a ship company in the lone Southern Ocean. Let the vessel, handled by the most courageous and skilful captain, put on what speed she may before the tremendous thrust of 


\section{2 \\ The Albatross}

the westerly gale, level with her mizenmast head and a little to windward is poised her snowy companion, apparently motionless, except for an almost imperceptible bending of the wings or tail for steering purposes. The bird seems to be held in the vicinity of the ship by some non-understandable magnetic force, for in no other way does his effortless maintenance of station appear possible in relation to the ship while the latter is fleeing over the ocean at the rate of from fifteen to seventeen miles an hour.

And then, if aught be dropped from the ship, the great bird gives a sudden swerve, sometimes rearing in a horizontal position and, stretching forward his wide-webbed feet, descending almost straight upon the spot where his piercing eye can see something that may be eatable. If that something has sunk, the Albatross will dive, despite the hampering of his huge wings, and by great exertions swim downward. Then, when the food has been secured, or whatever is there found to be eatable, the bird takes off from the crest of a wave, just melts into the air as it were, without any exertion, and although the ship by this time may be out of sight, an inappreciable portion of time serves to bring her attendant into station again.

Or in the midst of his steady accompanying of the vessel he will suddenly swerve to one side or other, as the case may be, and disappear, so swiftly yet so easily that the eye can barely follow him. The time passes, there is a sense of loss, for indeed in those latitudes during a heavy gale, their normal weather, the sea seems very lonely; when presently, behold our friend is visible in his old station, his beautiful snowy head with its dark solemn eyes turning gravely from side to side in keenest watchfulness. As he went, so he returns, so he remains, without effort, and the 


\section{At Home Only in Air 333}

mind grows bewildered in the attempt to understand how he can, apparently with such consummate ease. resist the fury of the wind.

Not that it would be correct to say that the Albatross never does flap his wings. When rising from the sea, if the latter is calm, it appears necessary for him to put forth all his undoubtedly great strength in order to effect his purpose. Spreading his wings wide, he commences to run along the sea-surface, the beating of his feet against the water being audible a long way off on a calm day. At the same time the great wings flap heavily as do a pelican's, until, by one supreme effort, the body is lifted into the air, and immediately assumes its normally calm pose, that makes it appear as if the bird by the slightest alteration in the plane of his wings and tail were able to make the air bear him whithersoever he wishes to go, even in the teeth of an on-rushing storm.

But before we go any further, a little description of the bird is necessary, for I have discovered long since that it is not wise to take for granted that readers know the appearance of even the commonest of seabirds, although almost every good general museum possesses one. The Albatross is about the size of a medium goose, but not so 'stockily' built, and with a much shorter neck. The beak is pale yellow in colour, from eight to ten inches in length, with nostrils on the upper mandible about two inches from its root. This upper mandible has a formidable-looking hook at the end, which curves down over the point of the lower mandible to a length of one and a half inches and tapers to a very keen point. At the junction of the mandibles with the head they are capable of great expansion, permitting the bird to swallow masses of food, such as blubber, at least four inches 


\section{The Albatross}

square, although I believe I have seen them swallow larger pieces than that.

But the peculiarly distinctive feature of the Albatross is its great pair of wings. They have three joints, and when wide-spread the front edges make almost perfect right angles with the body. And their extent from tip to tip is sometimes as much as sixteen feet, or over five yards. Their breadth from front to back is about eight inches, but at the last joint they begin to taper off to a point. The colour of the upper part of the wing is invariably a dark brown, which often extends across the back, while that of the rest of the body is pure white.

The feathers are very thick and deep, and beneath them there is a coating of the softest down, as fine as the best of that obtained from the eider duck. But I regret to say that this pure soft white fluff is the home of a multitude of parasites, from which none of the birds are free. The flesh of the bird is, as might be expected from its habits, exceedingly tough; in colour it is nearly black, becoming quite so after a brief exposure to the air. Also it has a very rank oily flavour of stale fish, making it quite uneatable to the ordinary person. French sailors, however, with the culinary aptitude of their nation, hang it until it is nearly putrid, and then make stews of it, which they profess to find excellent.

The Albatross seldom obtains a meal of fresh fish, his movements in or near the water not being smart enough to secure them. Consequently he is confined to feeding upon offal. And such offal! The carcase of a whale a few days after death as it floats upon the sea is extraordinarily offensive, but whenever one is found it is always the centre of a clamorous multitude of sea-birds, and when this happens to be 
in the haunts of the Albatross, these birds are always in the majority, for they angrily drive away all others. It seems rather a pity that so splendid a creature should be such a foul and greedy feeder, but so it is. It never seems to have had enough, even though it should have so loaded its stomach that it cannot rise from the water. It sits there almost helplessly, now and then giving utterance to a harsh scream, as if of rage at its inability to eat any more. And very often it may be seen to disgorge a quantity of what it has swallowed, and immediately rush upon the carcase again as if eager to renew its rapacious devourings, at the same time dealing savage blows right and left at its neighbours. It seems to think that none have any right to be at the great banquet but itself.

Dr. Hartwig says that the Albatross alights in considerable numbers upon the body of a dead whale and there tears its food from the giant carrion. But this is wrong. In the southern hemisphere, where alone the Albatross is found, the only bird that can and does alight upon the body of a whale is the evilsmelling fulmar, or giant petrel, an ugly bird as big as an ordinary duck and armed with a dirty greenish beak, with which it tears and rends the blubber, to the envious disgust of the other birds who cannot perform the same feat.

I would not like to assert that the Albatross has a superior development of the senses to other seabirds, but I believe that he has. At any rate, in common with all soaring carrion-eaters, he possesses the power of discerning, either by sight or scent, or some other sense unknown to us, food at immense distances. Again and again I have noted when whaling in the Southern seas that during the chase there has 


\section{The Albatross}

been scarcely a bird visible anywhere, even from the crow's-rest. But by the time the whale was dead the number of Albatrosses around the ship was countless. They drifted towards us out of the vast void and settled upon the water until oftentimes we seemed to be the centre of a great snow-field. And there those feathered hosts awaited patiently, silently, the preparation of their banquet. Yet in this promptitude of arrival they were far behind the sharks, who appeared upon the scene from the solitude of ocean directly the flow of blood had tainted the water, and, as soon as the whale was dead, began to tear at the limp body of the huge mammal.

But when once we began to cut at the carcase the eagerness of the birds could no longer be restrained. With hoarse shrieks they crowded over one another, even under the blows of the sharp spades, and I have several times seen a man, who with a bowline round him has been lowered down upon the whale in order to insert a blubber hook into its throat, overwhelmed by a rush of Albatrosses borne by an incoming sea right upon him, and he has had to grab armfuls of the ravenous birds and hurl them away from him before he could accomplish his task. But unless by an accident, such as the piercing of the case and the consequent leakage of the spermaceti, which floated astern like cakes of wax, the hungry hordes never got more than an occasional scrap or so until we had done with the body.

The Albatross is never seen alive north of the Equator. Up to a certain latitude he can venture, but he is essentially a cold-water bird, and no sooner does he find the temperature rise above a moderate degree of warmth than he retires south again into his well-beloved regions of cold and storm. The 


\section{The Faithful Albatross}

heat of the tropics would be at once fatal to him. Many attempts have been made to bring one of these wonderful birds home alive, but all have been failures; because for one thing it is impossible to induce the Albatross to take food on board ship, nor if he did eat could he retain what he had swallowed. The first thing done by the captured Albatross when landed on deck is to eject the total contents of his stomach, as if the motion of the vessel, even on the calmest day, was sufficient to make him violently sea-sick. Other sea-birds are liable to the same disability, but none in so marked a degree as the Albatross.

As a spouse he occupies a high place, except that he only pairs for the season, and the constant companionship of the male and female is pretty to see. He seems to realise his position of protector and provider in the highest degree, and not until the incubating period is over does this loving union cease. The female lays but one egg, about as large as that of a goose, apparently in the first suitable spot she finds upon the island where she was born. But she does not bother with nest-building any more than do the majority of sea-birds, a little hollow in the sand or a ledge of rock suffices, and there she sits upon her single egg, fed and kept company with by her ardent spouse, until the day when from that egg there appears a funny little ball of snowy down with two intensely black beady eyes and a gaping beak that seems to split its head in two halves.

The father now departs, disgusted apparently at the sight of this rival in the affections of his wife. She then devotes all her energies to feeding the baby, no easy task, one would think, where there are oftentimes several thousands of her own kind, to say nothing of myriads of other sea-birds, close at hand. But 


\section{8 \\ The Albatross}

she succeeds so well that after six weeks or so the youngster is bulkier than herself, looks, in fact, like a large and almost shapeless, except for the head, bundle of down, which retains its pristine snowy whiteness so as to be almost dazzling.

All this time it is almost helpless from its fatness and the weakness of its legs. But presently wings begin to sprout and feathers to appear. Soon it is ready for its first lessons in flight, and tremblingly, with tottering steps, it toddles after its mother to the sea. No sooner is it launched upon this element, than it seems to lose its ungainliness of outline, and to develop with amazing rapidity those characteristics which will presently raise it so far above the other denizens of the free heavens. At last it has learned to soar into its proper element, the sky; fully fledged and strong-winged, it takes its place among its fellows, and its mother, her work done, spreads her mighty wings and departs, to meet it knowingly no more.

Hitherto I have spoken entirely of the Albatross, the head of the family, but now we come to the other two species with which I am acquainted. I do not know the scientific names for them, have never been able to ascertain them, but to sailors frequenting the Southern Seas they are both very well known by the names of Mollymauks or Mallemucks, and Cape Hens. The first is an exceedingly beautiful bird differing scarcely at all from the albatross, except in point of size and a little more variety of marking. It is also much more active, flapping its wings far more frequently than does the albatross, and rising from the water with much less effort and consequently greater rapidity.

I have been told that it is sometimes found in the Far North, but I have never seen it there, so that 


\section{The Lively Mollymauk}

I cannot say whether the statement is a fact or not. Personally, I should be inclined to say that it is not found any farther north than its great relative. It is exceedingly plentiful in the ' roaring forties,' being far more often seen by ordinary merchantmen than the albatross. It is a constant attendant upon ships for the sake of the scraps thrown overboard, but except in a gale it does not keep anything like so stately a poise about them. It is continually on the go, wheeling about the ship, darting away and returning, and oftentimes it may be seen snatching a morsel from beneath the very feet of a descending albatross, which drops into the water with an angry protesting cry and watches grimly the quick fluttering away of the interloper. It rarely exceeds six feet in the breadth of its wings, and they do not stand out quite so straightly from the body as do those of the albatross. It is so rapid in its movements that it is often caught while the vessel is going as much as four knots an hour through the water, when it requires almost a dead calm to catch an albatross, the latter being so very deliberate in his movements.

The plan usually adopted, but entirely reprehensible, is to take a sail-hook, which has a long stem, a straight jaw and no barb, and fasten it to a long fishing-line. A strip of fat pork, raw, with the rind on, is then fastened to the hook in such a manner than the bow of the hook, though concealed, is quite free from being hampered by the tough fat. The bait is tied up the shank of the hook, so that when the line is towing the hook shall be first seized by a would-be devourer of the pork. The moment the bird is seen hovering overhead, the bait is flung out and the line let run as rapidly as possible. Thus until the whole of the line is run out, the bait is nearly 
stationary in the water, except that it is sinking. As soon as the bird sees the bait fall he drops into the sea and dives for it ; the moment he seizes it the fisherman hauls in, and in nine cases out of ten the sail-hook catches in the hook of the beak. The bird spreads its wings wide, thrusts its feet forward against the water and shakes its head vigorously, but to no purpose ; the steady strain is kept up, and presently the beautiful creature is landed on deck, all its gracefulness gone. It is a helpless arrival in a strange sphere surrounded by ruthless enemies. Then it is slain, but so that the snowy whiteness of the skin may be kept unsoiled, the poor bird is usually strangled or beaten on the head with a belaying-pin, both of which barbarous methods of treatment have to be persevered in for some time in order that the fell purpose may be effected, as the bird is very tenacious of life.

The Cape Hen is a busy brown albatross with a dirty white beak, exceedingly plentiful in the same habitat as the albatross and mollymauk. It has no relieving tint at all, its sober plumage seeming quite out of place among the snowy gatherings of its far more beautiful comrades. In fact, I should say that among the many aerial tribes of ocean it is the most dingily clad. The sailor of old used to know it very well, for it came much more readily to his hook than the other birds, and the long hollow bones of its wings made him excellent pipe-stems. So of course did those of the albatross and mollymauk, but they were much less easily obtained than those of the Cape Hen.

Another fad of the sailor was to fashion a tobacco pouch out of the feet of these birds, a task demanding much patience, and the resultant bag being by no 


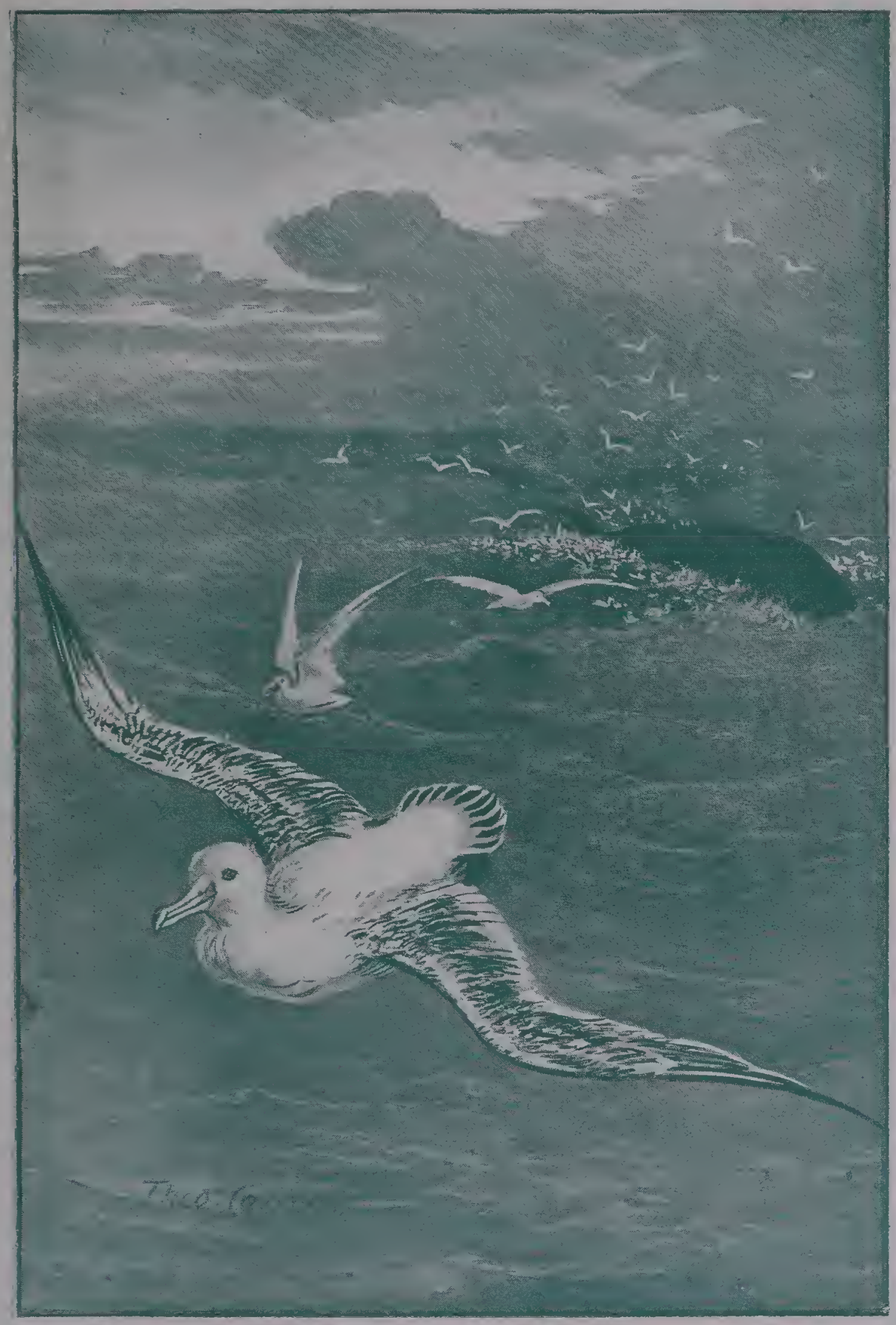

THE ALBATROSS.

[T face p. $37 \mathrm{c}$. 



\section{His Story}

means serviceable. In fact, it was on a par with the shark's backbone walking-stick over which so many weary hours used to be spent, the product being neither useful nor beautiful. The membraneous covering of a sea-bird's feet is double, and if the foot is cut off at the knee-joint by careful manipulation the bones may be withdrawn, all but the nails at the extremities, which are left for ornament. Then the adhering webs may be gently separated, and so the foot becomes a bag, the sides having a natural join which does not require a seam. But it does seen a trivial purpose for which to slay a beautiful inhabitant of the sea. Moreover, I can say with certainty that I have never seen one used for carrying tobacco.

And now, as I have done before in the case of Deep-sea Folks, let me endeavour to sketch for you the career of the young Albatross. He whom we saw but lately hatched out upon an outlying spur of the 'Crozets that tusk the Southern Pole.' Let him tell his own story:

How well I remember following clumsily my mother down to the sea. Until then I had never stirred from the little hollow of sand which was all my world. I was not even conscious that of my own kind there was an enormous company near me. All my sensations centred in one, hunger and its satisfying. I felt myself growing, of course, and every now and then would stretch out stumpy, down-covered wings, but hunger was my only real feeling. My mother fed me continually, as it seemed to me she had hardly left me before she was returning, but even so I was angrily squawking for her before she reached me. And no sooner had the food slipped down my wide gullet than I was ready for more. It was my sole object in life. 


\section{2 \\ The Albatross}

But when the moment came that she called me to come, and the great outside world broke upon my astonished gaze, I instinctively obeyed her, feeling in every muscle of my body a summons to action. It was a rugged way we traversed, bestrewn with youngsters like myself, many of whom were bound on the same errand, but it all seemed in some curious way familiar. When, however, we reached the sea's margin and my mother fondly led me in, the water greeted me with a roar and a dash of white foam that flung me gasping and kicking back upon the sand. Yet I felt quite unable to quit the attempt and wait for a more propitious occasion. Again and again I made a trial, encouraged by the easy way in which my mother rode over those insolent breakers in absolute supremacy.

And of course at last I succeeded. A smaller breaker than usual let me pass, and I found myself in the midst of a wide blue heaving plain, my mother by my side, drinking the salt water with great relish. And then to my horror she spread her great wings and ran along the water away from me. Suddenly she bounded into the blue above and circled over me with infinite grace, gently wooing me to join her with softest sounds of love. But I dared not. The imitative instinct within me was very strong, but I could not for some time obey it. When at last I did try to run along the water after my mother, I only collapsed in a draggled heap. But that experience, instead of daunting me, seemed to string up my nerves, and I tried again almost immediately. Indeed, I could not help doing so, for there was within me a power pushing me forward irresistibly. At last with one great effort I soared into the air. Ah! the delight of it, the unspeakable joy of finding oneself master 


\section{Elementary Education}

of his own element ! I circled round and round slowly, my breast swelling with the pride of life, and my mother hovering by my side gave utterance to low, gentle sounds of joy. Together we returned to my birthplace, my first lesson well and fully learned. I settled down upon the familiar spot, and my mother went back to the sea to forage for us both.

I went away no more that day, but on the next morning awoke and stretched my new wings crying clamorously for food. But my mother was already on her painful way down to the sea, and, except for a reproachful look in my direction occasionally, paid no heed to me. So I followed her quickly. I wanted food, and I felt that I might get some sooner if I made an effort myself. We launched ourselves together, this time without any difficulty on my part, for I had learned how to bear myself in relation to the water. No longer were the smoothly rolling waves as they swelled in upon the beach able to fling me, a muchbedraggled bunch of patchy fluff with ungainly wings and gaping beak, back upon the sand.

And moreover that morning we had only flown a short distance when the beautiful form of my mother gliding along before me suddenly stopped, her feet shot out before her, and down she came, I following her. The water was alive with squid, and all that we needed to do was just to scoop them in as fast as we would. The other birds of all kinds saw us drop, and before we had been eating a minute the air was dark overhead with them hurrying to the feast. My mother dealt fierce blows at any intruder that came within reach, and I followed her example instinctively, not that there was any need to drive others away, for the supply was vast enough for an enormous host of our fellows, but because it is natural 


\section{The Albatross}

for us to suppose that there will not be sufficient for us.

Presently I found that by no possibility could I squeeze in one more delicious morsel, and after ungratefully meditating awhile upon the curious discovery that while I still desired to eat, I had no storage room, I essayed to rise and fly homeward. But that too I found out of the question. And my mother was in a like condition. Do not think us greedy-if we do eat voraciously, and grumble that we can hold no more when food is so abundant, it is because we know so well how often we must go for days and days 'without anything at all to sustain us but a sup or so of the bitter brine beneath us. I did not know this experimentally, of course, but the sense of its possibility was there, inherited from my parents.

As we sat gently rocking upon the smooth swell, surrounded by struggling, shrieking birds of all seakinds common to those isles, there was a sudden rushing away of the nearest of our neighbours, a great shadow came between us and the sun, and a mighty Albatross of purest white descended gracefully by my side. $\mathrm{He}$ made a careless lunge at me with his" enormous beak, which I only just evaded by a desperate effort, for I could hardly move, and then leisurely folding one vast wing after the other went on feeding, disdaining any notice of his fellows. None of them came near, they scemed to have far too great a regard for their safety to venture within his reach, so that he had quite a large area of sea to himself.

I was terribly alarmed, but helpless to get away as the others had done, being so much overloaded with food. But he took no further notice of me, although I was so close, and I kept as still as possible 


\section{Parental Amenities}

lest he should. Presently he too had eaten his fill, and I noted with terror that he was swimming steadily towards my mother, who swam away, it is true, but not with any vigour, although I could see her glancing apprehensively over her shoulder at him. Presently he was by her side, and laying his great beak across her neck he caressed her gently, at the same time uttering a pleasant little musical sound entirely unlike the usual strident shriek of our people. What it meant I did not know. Curiosity overcame my fears, and I swam heavily towards the pair to see, if I could, what this behaviour meant, when to my horror the new-comer suddenly turned and, rushing at me, struck me so heavy a blow with his hooked beak that the flesh was torn off a portion of my back and my snowy plumage became red. I tried to escape, but still could hardly move, until suddenly the impulse came upon me to disgorge a portion of what I had eaten. As I did so, I felt easier and was able to 11 se. With all the strength at my command I fled away, nor even looked behind until I regained the old spot where I had been hatched. There I waited, full of miserable apprehensions lest that terrible bird should come and destroy me. Had I only known it, or my fears have allowed me to look back during my headlong flight, he was not pursuing me-I was altogether beneath his notice, except when I came too near him.

The day passed slowly away, but my mother did not return. I became hungry, but I was afraid to move. Flocks of my neighbours returned from their labours and settled down on their respective spots, inquisitive little birds and cunning crabs ran all about me, but I was entirely alone. In vain I strained my eyes longingly seaward, until the sudden 


\section{The Albatross}

dusk fell, the stars peeped out, and only a few white gleams in the gloom around me showed where restless birds were still unable to settle down. Presently, in obedience to a compelling need, I tucked my head into the cosy underside of my wing and forgot my new trouble and loneliness in a sound sleep.

Morning broke in storm, and with heavy driving snow blotting out all sight of the surrounding land and sea. I huddled closer down upon the sand, shivering in spite of my warm garment, and missed my mother. I was very hungry, and that fierce sensation was driving me forth to seek food. But when even the old birds were loth to leave their nests what could a fledgeling hope to do? Oh, how I longed for the strong tender guide and careful provider that I had lost! Never again was I to know her, and presently, hardly knowing what I did, I gathered all my forces and rushed down to the sea. A huge breaker caught me, hurled me high on its crest in a smother of blinding spray, from which I took off into the snowladen air, stretching my wings with a sense of power that was exhilarating and uttering a long shrill cry born of hunger, anger, and defiance.

So I soared aloft and at right angles to the wind, using it in that mysterious unexplainable way that we have to speed me forward, but whither I did not know, could not recognise the sense of direction I possessed, yet I knew I was going right. And presently a delicious scent, the strong odour of a decaying whale, greeted me, and, with a prompt lowering of my pinions and extension of my feet, I went down, down into the midst of a great company of my kind engaged in a mighty banquet. It was a stupendous scene, for it seemed as if it were a gathering of all the tribes of air and sea. The storm thundered, the birds 


\section{Take my Place}

screamed, the waves of the sea were all torn and boiling with the myriads of hungry fish who were seeking their share of the feast, and in the midst of it all lay solemnly still, majestic in death, the body of the feast. Heedless of passing blows, only lunging back at the givers, I fought my way into the middle of the tumult and found food, fat; delicious, satisfying food. I ate and fought and shrieked with the rest, all the time feeling sensible that I was now a free citizen of the ocean, henceforward able to hold my own among my kind.

My hunger satisfied, I drifted away from the tremendous clamouring crowd, and quietly rocking upon the mighty billows which swept up from the South Pole like walls of water, I slept as peacefully as I had ever done beneath my mother's sheltering wing. I was not in the least disturbed by the incessant coming and going of multitudes of birds, any more than I was by the uproar of the storm or the hissing of the spindrift about me; I was in my own rightful realm, and fully conscious that it was so. No necessity was laid upon me to rise from my rolling couch, so that the mass of food I had eaten was fully digested, and when I at last became conscious that it was time to seek more food I felt splendidly grown and fit for action. I rose on the wing and returned to where, very greatly reduced but still enormous, the body of the whale floated surrounded by vociferous birds as thickly as ever. The sight invigorated me, and with a long scream of triumph and defiance I again took my place at the great meal.

Another feast, another rest, and I began my long roaming. I followed one ship for many days, easily keeping up with her at her utmost speed, in fact my motion was so easy though so swift that I was barely 


\section{The Albatross}

conscious of any effort, except to restrain myself from shooting past her. I got to know the appearance of the creatures on deck, as they certainly got to know me, for often I would poise myself quite low down to windward and gaze with full, unwinking eyes upon their faces, while they in turn stared most curiously at me. I grew quite to like them, especially as they fed me bountifully, although I grieve to say that I was often shamelessly robbed by the small fry that clustered in the vessel's wake and because of their insignificance were able to descend and arise very much quicker than I could. For the same reason they were able to evade my righteously angry attempts to deal with them as they deserved.

Then a horrible thing happened. The wind died away until the ship lay almost motionless, and because there was no use in flying continually around her now that she was still, and as I was loth to leave her, I sat in quiet dignity on the water near her. Presently I saw a beautiful piece of fat floating near me, tugged at by some Cape pigeons who were unable to rise with it for some strange reason. I drove them away, for how dared they thus encroach upon my preserves? and seized it myself. No sooner had I done so than I found myself being dragged through the water forward by my head. In vain I spread my wings, shook my head vigorously from side to side, held my broad feet out in front of me. I found myself lifted in air and suddenly dropped upon a smooth white surface, very hard to my feet. I became violently sick and ill, but I was surrounded by the creatures I had so long seen standing on the ship, and they only jeered at me. Worse than that, one seized my beak, while another riveted a small chain around my neck, and daubed circles round my eyes with some red sticky stuff. 


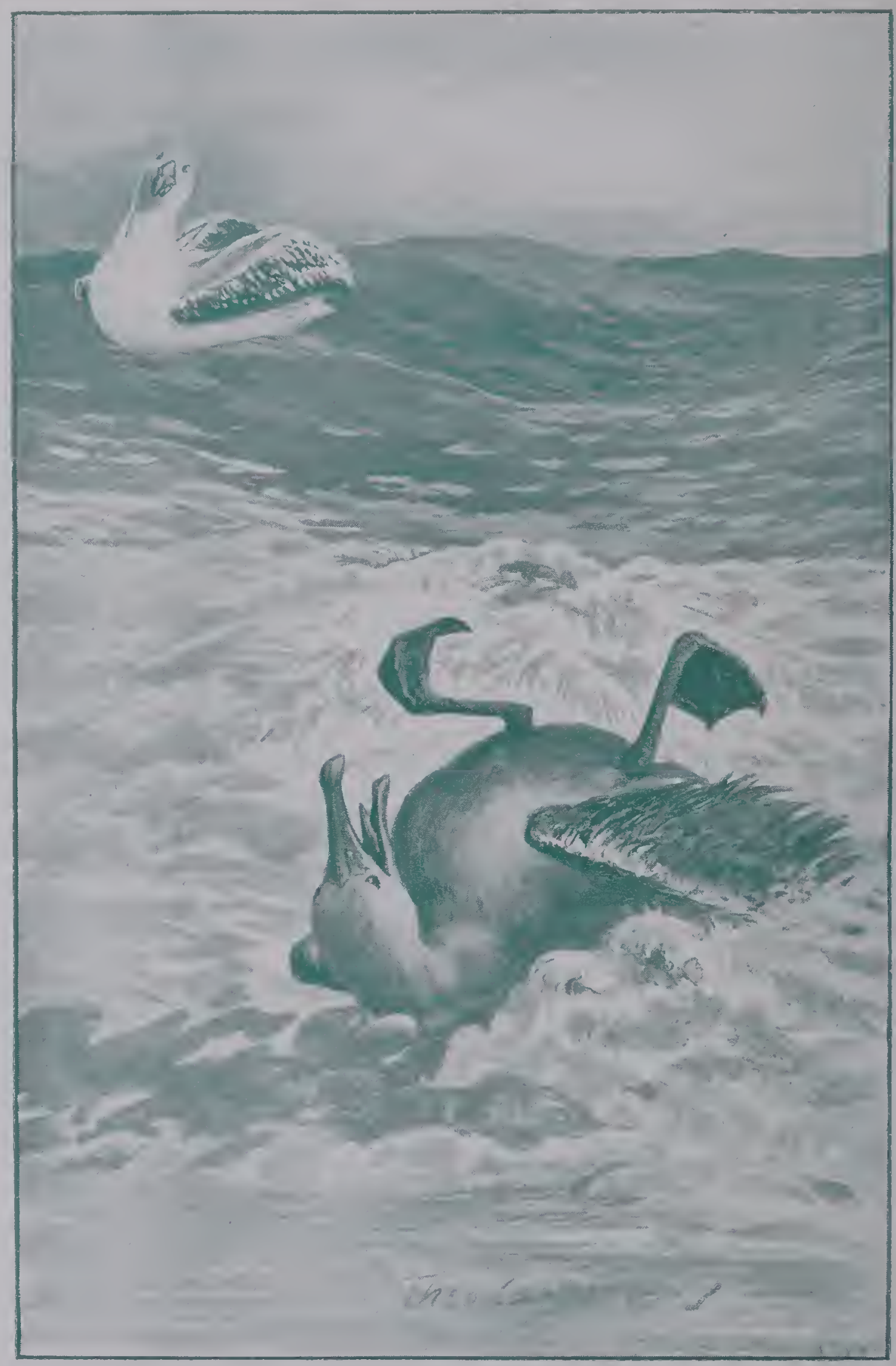

ILH TO HIS OTW I RESOLRCE-

Te bace t. its 
Then, having thus disfigured me, they flung me over into the sea again, outraged, dishevelled, and bewildered.

Never again have I been foolish enough to eat anything flung from a ship in a calm without closely examining it ; indeed, I do not care to go near ships at all. But alas! I have never been able to rid myself of that galling chain, which for a long while made me an outcast among my kind. Fortunately we do not crave company, having great powers of self-entertainment. Also we feel our royal state, and do not suffer the intimacy of those beneath us. At last, however, I found me a beautiful consort, who rather regarded my collar as an added adornment, singling me out from all others of my family as one who had seen and endured strange things not given to the general to become acquainted with. Together we roamed the round world, enjoying life to the full and supremely happy in each other. Then we retired to a lonely crag in the South Shetlands, whereon my consort became the proud possessor of a beautiful egg. And I watched over her, fed her, cheered her in her weary period of sitting, wondering much in a dumb, wistful way why she would not again come roaming the wide sea with me. But she did not, could not, and when presently a fluffy white ball with gaping mouth appeared, she forgot me altogether, and I fled angrily away. 


\section{CHAPTER XXIV}

\section{CAPE PIGEONS AND WHALE BIRDS}

THE Pintado Petrel, as the Cape Pigeon is somewhat pedantically called by the naturalist, is a most delightful and cheery little bird, although his habitat is one of the loneliest known. If I dared, I would say that the Cape Pigeon is the marine counterpart of the peewit or plover. But an unscientific observer does get dropped upon so for a casual remark like that, that perhaps I had better go no farther than to say that in colour, in flight, and in voice; yes, and in size also, there is a very distinct and striking similarity between the pretty black-and-white citizen of the great South Sea and the peewit of the newlyploughed land in our own dear home. In vivacity of movement the difference is in favour of the sea-bird -an overmastering energy seems to be continually impelling it to action, and I should be quite prepared to find that it does not sit quietly upon its eggs.

But perhaps before I go any farther I must try to give a little description of this, to southern-going seamen, exceedingly well-known bird, though to naturalists hardly known at all. In size it is between an ordinary tame pigeon and a wood-pigeon, not quite so elegant in its outlines, and with a somewhat larger head in proportion to the size of its body. Like all the petrels, it has a hooked beak, which is really an 


\section{Its Restless Vivacity $35 \mathrm{I}$}

absolute necessity, considering the rapidity with which it must seize its slimy food. Its plumage is just white and black, white as regards the bulk of the body, breast, neck, etc., with a curiously regular and conventional pattern of black across the upper part of the wings and body. Its head is like a ball of black velvet, its feet are like the wings of a little bat, so silky and nervously energetic are they.

Like all its congeners, and for the same reason, it eats whatever it can get that is eatable-that is to say, eatable in its very wide ideas of what constitutes really edible food. It samples everything, rejecting only that which is obviously impossible, like wood or pumice-stone, of which latter produce of submarine fires there is often abundance floating in Southern Seas. But its chief characteristic is its cheery vivacity. In lovableness I cannot give it the place of honour, when I remember the little darling of all the wide oceans, the Mother Carey's chicken, but it is a close second. And I am filled with sorrow when I remember how many I have seen caught or wantonly shot by passengers for amusement. The necessity could never arise, except in case of shipwreck and consequent starvation, for these deep-sea birds are all practically uneatable except when overpowering hunger compels. Their flesh is rank, oily, and hard, the muscles being indurated by their amazingly active life.

The Whale Birds, so-called from an utterly unfounded superstition among the whale-fishers that their appearance in large flocks heralds the approach or the immediate vicinity of whales, are almost mysterious in their aloofness from man. Whereas the albatross, the mollymauk, Cape hen, and Mother Carey's chicken, with especially the Cape pigeon, act towards passing ships as if they too realised intensely 


\section{Cape Prgeons and Whale Birds}

the grim loneliness of the vast Southern Sea, the Whale Birds are content with their own company, but that is always in large numbers. Again, a great distinction from all other Southern Sea birds, who, while rarely abiding in entire solitude as regards their own kind, almost always confine their companionship to one or two chosen chums with whom to scour the wide free spaces of Antarctica, Whale Birds are never seen but in flocks numbering some hundreds, and that only when there is much food about. Yet I never saw them feeding at such a time. I have often seen them hovering about above the crowds of vociferous roysterers assisting at the demolishment of a dead whale; but it seemed a pure absurdity to imagine them descending into that dread arena within reach of lethal beaks and mighty wings, for they are tiny birds, scarcely larger than the stormy petrel, and more elegantly built.

The sandpiper is, I think, the nearest of possibly familiar birds with which I can compare them. White and dove colour is their plumage, their main characteristic timidity, and their voice has a gently cooing note in it, as if deprecating their enterprise in thus apparently coming into serious competition with the far more strenuous inhabitants of the sea spaces. It is principally for this reason that I have called them mysterious. I cannot at all understand how they are able to hold their own, to live and keep plentiful in those stern regions.

In the particulars which follow I hope it will be understood that I am describing entirely from memory, my mind must reach back a quarter of a century for detail unobtainable elsewhere. Imagine a thrush, almost pure white except across the wings and the top of the head, and with wings half as long again, 


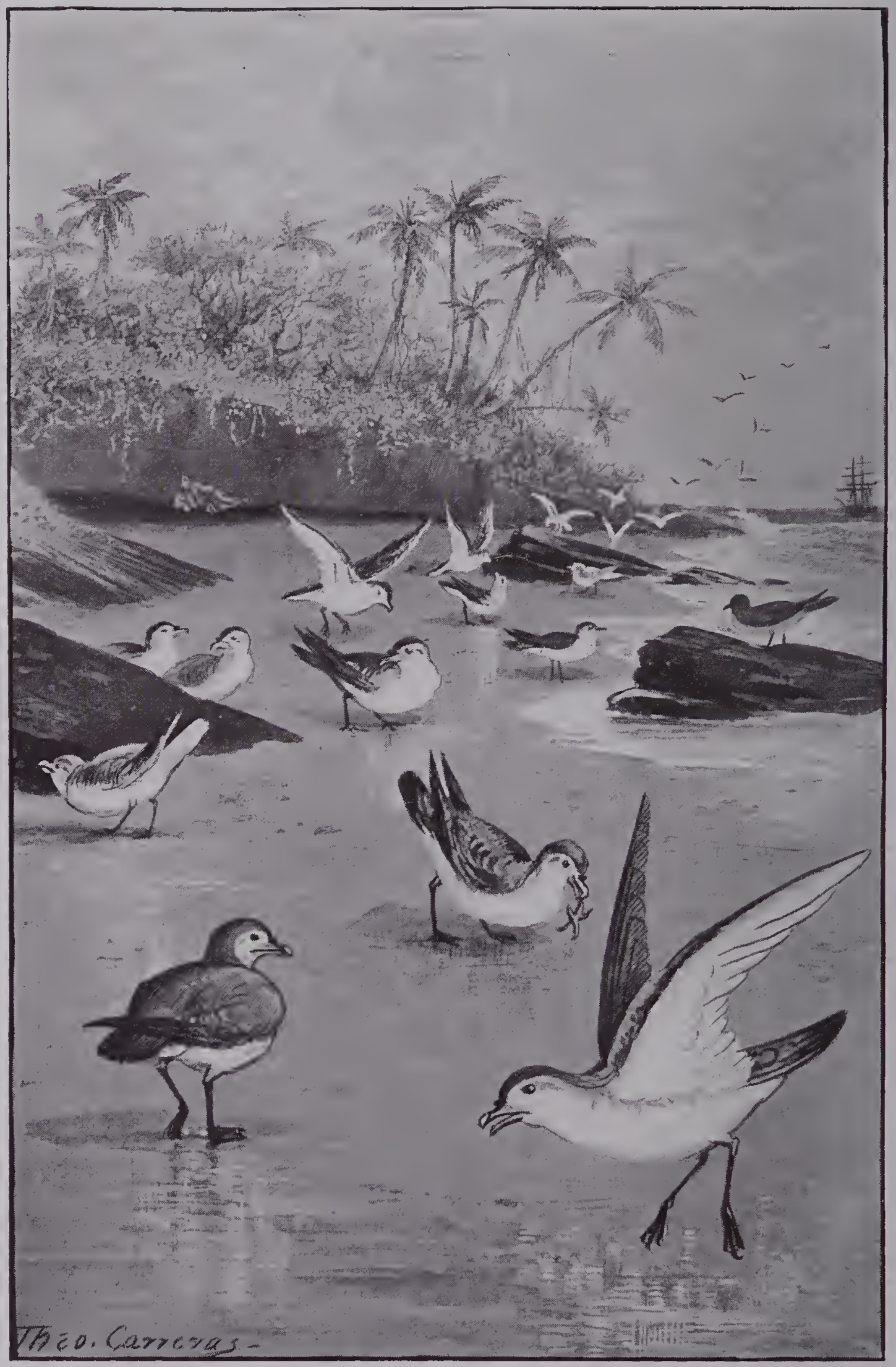

IVHALEBIRDS.

[To face $p .353$. 


\section{Timid Sea Citizens}

pointed almost like those of a swift. The beak is straight and nearly white, the eyes, in common with most sea-birds, full and dark. The legs are long in proportion, and of a yellowish hue, feet small with delicate webs, and tail slender and tapering. In spite of the shape of its wings it does not fly with the darting sweep of the swallow, nor has it the bold, decided action of the thrush when on the wing. In company with a band of its companions it flies slowly, almost heavily for so slightly built a bird, the whole flock rising and falling like a wave at a fairly level distance of some thirty or forty feet above the sea. Their movements are as unlike those of the ordinary seabirds as one can imagine, they appear to have no objective, and to be so timid that they hardly dare to descend and feed. Yet, as far as one can tell, there is no ground for this excessive fear. They do not appear to have any enemies, as indeed may be said of most of the Southern Sea birds, among men or birds or fish, so that when they die it is almost always by the operation of some peculiarly natural force.

The only time that I can ever remember seeing these tiny sea-wanderers feeding was once when landed upon an outlying cay of the Loyalty Islands for wood and cocoa-palm leaves for making brooms. We had toiled very hard for some hours, and had at last been graciously accorded a short rest for a smoke. I lay separated from my shipmates under the shadow of a great rock out of the fierce noon-day sun, dreamily puffing at my pipe, and gazing over the dazzling stretch of sand before me at the bold landward rush of the mighty breakers. Suddenly there appeared a small flock of Whale Birds gliding undulatory towards me from seaward, and with many a graceful flutter, settling and rising again, they finally folded all their 


\section{Cape Pigeons and Whale Birds}

pretty wings, and appeared content to remain. At the first I took them for terns, but remembered their flight and also their voices, which, instead of being sharp and penetrating like the cry of a tern, were soft and appealing; to one's imagination they were deprecating being alive at all. And then to my great interest they began to feed. Mincingly, delicately, they pattered about the sand near the sea-margin, prying with the fine points of their beaks into crannies, evidently finding much food of some sort, and that greatly to their taste.

For an hour I lay and watched them until, with a hurried scampering together, they rose in a little cloud and swept away out to sea. It was a shipmate of mine who, strolling leisurely along beachward, had startled them, for which I felt I could willingly have flung a stone at him. As soon as he saw me he asked if I had seen the birds, calling them by the correct whaler's name, Whale Birds, and when I grunted assent he inflicted upon me a foolish tedious yarn of there being something supernatural about Whale Birds. That they never ate and never rested because they had no feet, and other skittles of the kind. To which I replied that he might, had he used his eyes, have seen them both eating and walking a few minutes ago, and so have been able to enjoy the great pleasure of putting anybody right upon the subject who came to him with such a story. But he did not seem to see any advantage in that.

There can be no question about the right of the Whale Bird to be called one of the Deep Sea People proper, that is to say, as much so as the albatross or stormy petrel, because it inhabits precisely the same regions as they do, although not so frequently seen. But there is a certain amount of mystery attaching to 


\section{Apparently out of Place 355}

the little wanderers, from their never being seen to feed at sea or ever to alight on the water, although their feet are delicately webbed as if for swimming purposes. Added to all this is their apparently feeble, undecided flight, which seems so unnatural in a bird that is met with a thousand miles from land, and that does not avail itself, as far as can be told, of the rest afforded by the sea-surface. I have never been able to imagine what becomes of them in a gale. In theory they should be hurled along like dried leaves without power of direction, whithersoever the storm-wind chooses to carry them. But knowing what we do of the truly marvellous way in which all sea-birds can and do manipulate their pinions in the tremendous presence of the tempest, it is utterly unwise to suppose that even the feeble Whale Birds are unable to maintain their position and prosecute their mysterious business, no matter how fiercely the gale may rage about them.

As to their place of resort for breeding purposes, I know no more certainly than that they frequent at breeding time the same islets in the Southern Seas as do the larger pelagic birds. Also that they are to be found in warmer climates than the albatross and Cape pigeon, being in this respect, indeed, more like the dainty little Procellaria, which is equally at home on the Equator or amid the table-topped icebergs of the great lone Southern Sea. I should say, however, that they would breed in colonies, as they are so very gregarious, and that, judging from the little I have been able to see of their habits, they are as addicted to polygamy as is the domestic fowl, a circumstance which differentiates them at once from all the other really pelagic sea-birds.

Before we return to the Cape Pigeon, whom, after 


\section{Cape Pigeons and Whale Birds}

a very brief introduction, I left for a while in order to do ample justice to by-and-by, let us take a passing glimpse at a truly wonderful sea-bird which is frequently seen at great distances from land, but scarcely ever in company with another bird even of its own kind. I allude to the Tropic Bird (Phaeton etherius) which all sailors used to know as the 'Bo'sun,' for they said 'he carries his marlinespike for a tail.' This is in allusion to the two long, slender tail-feathers which stream out behind the bird as he flies, if the term flight can properly be applied to the stately and dignified way in which this beautiful lonely bird floats along in mid-air. In size it resembles a partridge, but in colour favours most sea-birds by being soberly clad in black, grey and white-white as to the breast, neck, and head, and grey spotted with black on the back and upper surfaces of the wings. These latter are large for the size of the bird, but somewhat narrow. They are rarely flapped by the bird, who, in common with the albatross, prefers to float in the air, and uses that element to propel it wherever it wishes to go by dexterous steering, to the fussy flutterings of less dignified citizens of the upper atmosphere. Its legs are very short and its feet very small, which, taken in conjunction with the length of its curious and delicate tail, has led to the assumption that it spends most of its time on the wing. Yet it is supposed by naturalists that these birds make a point of visiting the rocks of lonely islets which are their homes every night, and this because they are not seen to feed at sea. That I cannot believe, from the immense distances which 1 have seen them from land, and also because on going aloft to loose a royal on a fine night I have often heard their peculiar low cry, and seen the shadowy creature flit past like an uneasy ghost. 


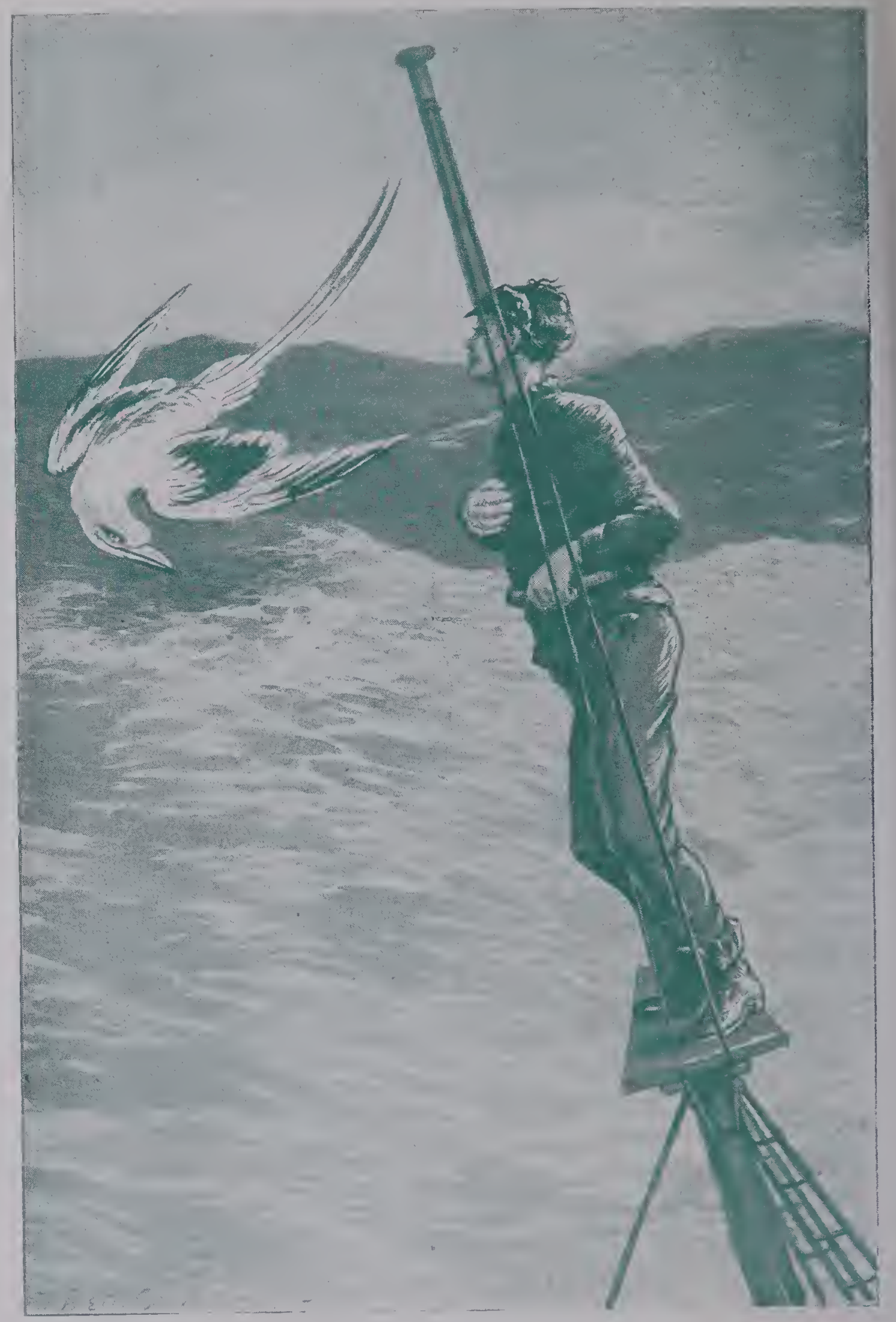

STRANGE COMPANIONS.

[T facit. 35i. 


\section{Aristocratic Aloofness 357}

But I admit that I have never seen them feed. In the crow's-nest of a whaler, when lazily turning to and fro on the Line grounds, I have often been kept pleasant company with by a bos'un, who just floated near, suspended in the clear ether, apparently fully engaged in the endeavour to decide what sort of strange bird I was. All the two hours' spell he would remain, hardly moving a feather, and when, after my four hours' watch below had been spent and I mounted to my lofty perch again, there he was still. I never saw such a bird descend more than a few feet; never saw him manifest the slightest interest in anything except the mastheads of the ship. And I have wondered, until my curiosity has been almost unbearable, how the pretty solitary lived-in fact, despite common-sense and reasoning power, there would obtrude a feeling of the uncanny, especially after gazing steadfastly into the deep dark eyes of the bird floating so near that I could almost touch him with my hand. I do not recall any instance where two of them thus accompanied a ship, but I do remember that whenever other birds came about the bos'un soon took his leave, just floated away and disappeared, with a fine aristocratic air of disliking any society but that which he had chosen for himself, a suggestion of being perfectly content with his entirely lonely life, and needing no external aids to comfort or happiness. In the tropical seas, however, at a distance from land, except for the tiny petrel, bird-life is comparatively scarce, and apparently this is just what the Tropic Bird desires and enjoys, with an occasional calm and serene criticism of the uncouth mortals who penetrate into his lonely realm.

Except in calms or very light winds the Tropic Bird is seldom observable from the masthead of an ordinary 


\section{$35^{8}$ Cape Pigeons and Whale Birds}

merchant sailing ship, hardly ever from a steamer. The first may be accompanied until the breeze freshens, when the bird, apparently disliking the speed, quietly melts into the vast emptiness around; the second poicons the surrounding atmosphere so vilely that any bird, to say nothing of the dignified bos'un, would find it an impossibility to retain even the semblance of fellowship and live. Except of course those busy birds that fly low, and keeping thus out of the befouled strata of air are able for a time to gather a little of the rich harvest of eatable scraps being whirled astern in the foaming eddy of the propeller.

I am exceedingly loth to leave the Tropic Bird, as he possesses for me a fascination greater than that of any other of the deep-sea birds. But he does so persistently and successfully maintain his aloofness, his mysterious independence of all those external aids to living which we must look for in the creatures we study, that unless I were to invent something about him I must come to an end of my talk about his ways. The question of how he breeds, and how-unless he builds a nest in a tree, as suggested by some naturalists, but which is to me a thing unthinkable of a sea-birdhe protects that long beautiful tail of his from defilement is an unsolvable mystery to me.

Undoubtedly there is a species of Tropic Bird which breeds, petrel-like, in holes of the rocks, and while ashore is gregarious, but it is not the species of which I am now writing. Perhaps it is well that there should remain even to-day some creatures of the upper air whom the lonely sailor can meet and admire, whose comings and goings are without observation, whose habits can only be guessed at, and whose lives, as far as may be seen, are from their beginning to their end bound up in the enjoyment of perfect unmolested peace. 


\section{My First Offence}

And now to return with some relief to my dear, merry, busy little friend, the Cape Pigeon, or Pintado Petrel, although I cannot feel at home with him under any other name than the first. Shame upon me, I first made his intimate acquaintance when outward bound in the 'Western Belle' to Bombay, so many years ago that recalling the date makes me feel quite old. I had only known him to look at for a few days when there fell a stark calm, in which he and dozens of his kind flitted joyously about us, exhibiting every graceful poise of their trim little bodies, and now and then showing what they could do in the way of diving. With wide-eyed wonder I watched a couple who had swooped upon a pork-bone I had flung overboard, pursue it down through the limpid blue, their wings widespread, flashing back the sapphire light, and a whole stream of turquoise bubbles ascending as they sped downwards. They rose unsuccessful, the prize they thought of securing was too hard, too heavy for their efforts, but with hardly a pause they sprang into the air again and recommenced their mazy whirl about us as if entirely unconcerned at the frustration of their keen desires. We have a monopoly, apparently, of the foolish occupation of fretting over what might have been.

It was then that an evil counsellor whispered to me that I might, an I chose, catch one of those dear desirable birds and have it for my own. Not only so, but he placed the means to do this ill-deed in my hand-a ball of roping twine, a little hook attached thereto, and a piece of fat. The poop was deserted save by the drowsy helmsman, the second mate (my bitter enemy) having taken advantage of the skipper's Sabbath siesta and the utter absence of wind to go below and do something in his berth 


\section{Cape Pigeons and Whale Birds}

So I stole up on the ponp, and leaning over the taffrail, cast my lure. It sank slowly but not out of sight of one of the busy little birds, which was presently in my trembling hands. I took it down on the maindeck and played with it, no loubt to its intense misery and the bewilderment of our two big dogs. The only excuse I can make for this cruel behaviour to one of the free and essentially harmless people of the air is thoughtless youth.

But the bird was presently avenged, for an elderly American seaman, whom I only remember as Nat, came noiselessly behind me, and seizing my ear in one hand, took the pretty frightened creature from me with the other, saying solemnly: 'Boy, hasn't anybody told ye that the meanest and lowest thing ye can do is to worry, annoy, and kill these lovely feathered things? They do no harm, they're not good to eat, and they brighten up and make cheerful the great ocean solitudes.' As he spoke he cast the bird into the air, and giving my ear such a tweak that I almost thought it had come off, stalked solemnly away. He was a pretty good man, was old Nat. I ran to the side and peeped over to see what had become of my late prisoner, and there within a biscuit's throw of the ship sat my late captive calmly restoring his feathers to their usual unruffled condition after their disarrangement by my rough handling. I have never molested another Cape Pigeon, although I have often seen it done.

During a tremendous westerly gale the great company of sea-birds which had so long followed the lumbering, heavy progress of an old barque that certainly should not have been sailing in those stern latitudes at all, had gradually dwindled away until only one faithful pair of Cape Pigeons remained. 


\section{Comforting Companions 361}

Usually, under such circumstances, the last birds seen about a ship, nay, those that never desert her while she swims, are the stormy petrels, but now these Pigeons alone were left. As one by one the last rent fragments of canvas flew from her yards and disappeared into the deepening gloom like wisps of cloud, the position of the barque became more and more critical, and it was evident that unless almost a miracle happened the enormous waves rolling up so relentlessly from the westward must presently overwhelm her, since she could not possibly under bare poles keep ahead of the sea.

But the brave, bright spirit of the skipper never faltered, and with great skill and coolness he succeeded in getting, by the aid of his good men, a tarpaulin lashed in the mizen rigging. Then carefully watching for the smooth after a ninth wave he let the old tub swing up into the wind, which caught and brought her into that comparatively easy position in a gale which we know as being ' hove to.' And as she lay there, sometimes almost head to the mighty waves, and rising upon their crests until it appeared as if her stern was about to be buried, or falling off into the deep trough between two billows, until it seemed as if she must be rolled bottom up, the two constant attendants upon her, the pair of Cape Pigeons, hovered about her as if they were guardian angels deputed to preserve her from the destruction which seemed imminent.

The old vessel now made such good weather of it, considering, that the skipper's wife brought up their little boy, who was very anxious to see what made the naughty ship tumble about so. And the first thing his bright eyes lighted upon was the pair of pretty birds hovering easily to windward over the 


\section{Cape Pigeons and Whale Birds}

broad, smooth eddies of the ship's sidelong drift, and watching keenly for scraps as usual. He clapped his hands with glee, and cried shrilly:

'Dada, those little birds don't mind the storm a bit, do they ?'

'No, dear,' said his father gravely, 'the sea is their home, don't you see ?'

The child meditated for a few moments, and then, his face brightening again, he cried: 'Well, dada, it's ours too, isn't it ?' Then, withont waiting for his father's reply, he said slowly: 'If Gentle Jesus can keep those pretty little birds in the midst of all this lot of water and big wind, of course $\mathrm{He}$ can keep us. I did feel 'fraid down in the cabin, but I don't now. I know what mumma meant by the story about Gentle Jesus and the five sparrows sold for two fardens. Not one of them can fall in the sea without your Father.'

The man at the wheel passed his oil-skinned sleeve across his eyes to wipe away the salt spray, the skipper turned away and cleared his throat, and the mother, tightening her hold upon her boy, felt a tear trickle down her drawn cheek; but all three realised the value of the message brought them by the child, entirely independent of their knowledge of the inexorable operation of natural forces. And it is safe to say that thenceforward, in spite of the walty state of the almost worn-out vessel, of their sorely hampered condition for fighting the stern elements in that rugged quarter of the globe, they had all gained immensely in the essentials for fighting the good fight which brave sailors are often called upon to wage, and, as in this case, with, metaphorically speaking, one hand tied behind them.

Within a few hours the gale blew itself out, and 


\section{Wedded Bliss}

shifted capriciously with snarling squalls round against the sun into the north-east. And this change seemed to bring to the minds (or what fills that office in birds) of the two Pigeons a duty that must be performed without further delay. For no sooner had the old barque been put upon the other tack, and all hands set busily to work replacing such sails as were essential, than they took two or three quick turns round her, as if fixing her outlines in their memories, and then mounting high in air, poised for a moment, and shot off due south for Prince Edward's Isle. They reached it before dusk, and a bleak, forbidding, storm-lashed place it was, to all human ideas. But the pretty little seafarers swept together into a sheltered corner between two gigantic boulders quite out of reach of the biting blasts and fitful showers of snow, and there for the first time for many weeks they nestled down together on the firm earth in closest companionship away from the surface of the never-resting sea. Little twitterings sounded contentedly through the gloom of the place, and bright eyes twinkling from snug crevices revealed the presence of many companions here on the same conjugal and familiar errand. And so the rugged savage rocks became beautified by the presence of happy life, and their usefulness as a shelter overtopped the sense of their exceedingly terrible aspect.

That night the little visitors slept soundly and unusually ; for it is a peculiarity of the lives of fish and birds-at least sea-birds-that sleep, which is so urgent a necessity to all land animals, is with them a luxury which may apparently be dispensed with for long periods without causing them any inconvenience. At least in any reasonable quantity, for one can hardly call the exceedingly brief snatches 


\section{Cape Pigeons and Whale Birds}

of slumber taken, say, by sea-birds on the wing, or riding easily the surface of gale-tormented billows, by the sweet and restful name of sleep.

Morning broke coldly and drearily. The lowhanging sky was full of snow, the moaning of the wind presaged storm, and the rocks bared their fangs like black icebergs. But in the tiny crevice, open to the heaven above, though shielded from the direct blast of the bitter wind, the two wee birds nestled side by side, cosy, content and warm. The beautiful garments of feathers and down wherewith Infinite Thought had clothed them were impervious to outer cold and wet, so long as fuel for the hot little body was forthcoming in sufflcient quantity. And they had each other, a delightful companionship wherein every desire, every intention coincided, not one jarring note or cranny for unhappiness to creep in and kill peace. So since there was no need as yet for active search for food, they sat gently communing, in tinkling notes quite unlike their shrill cries at sea, and frequently caressing one another with their beaks with a tender smoothing motion.

Meanwhile outside, the tremendous elemental orchestra tuned up, until about noon the awful concert began. The sea, outstripping the wind, as it often does down in those latitudes, hurled itself mountainously at those sullen rock-bases, sending sheets of hissing spray hundreds of feet into the air, and uttering a deep earthquake note more pervading than thunder. Then the gale, angry, shrieking and searching, burst upon the island, tearing the crests from the billows, and drenching the whole area of land with briny spray. And simultaneously the deep-keeled clouds, torn into massy fragments by the frantic storm, cast forth their burden of water, which, passing through the 


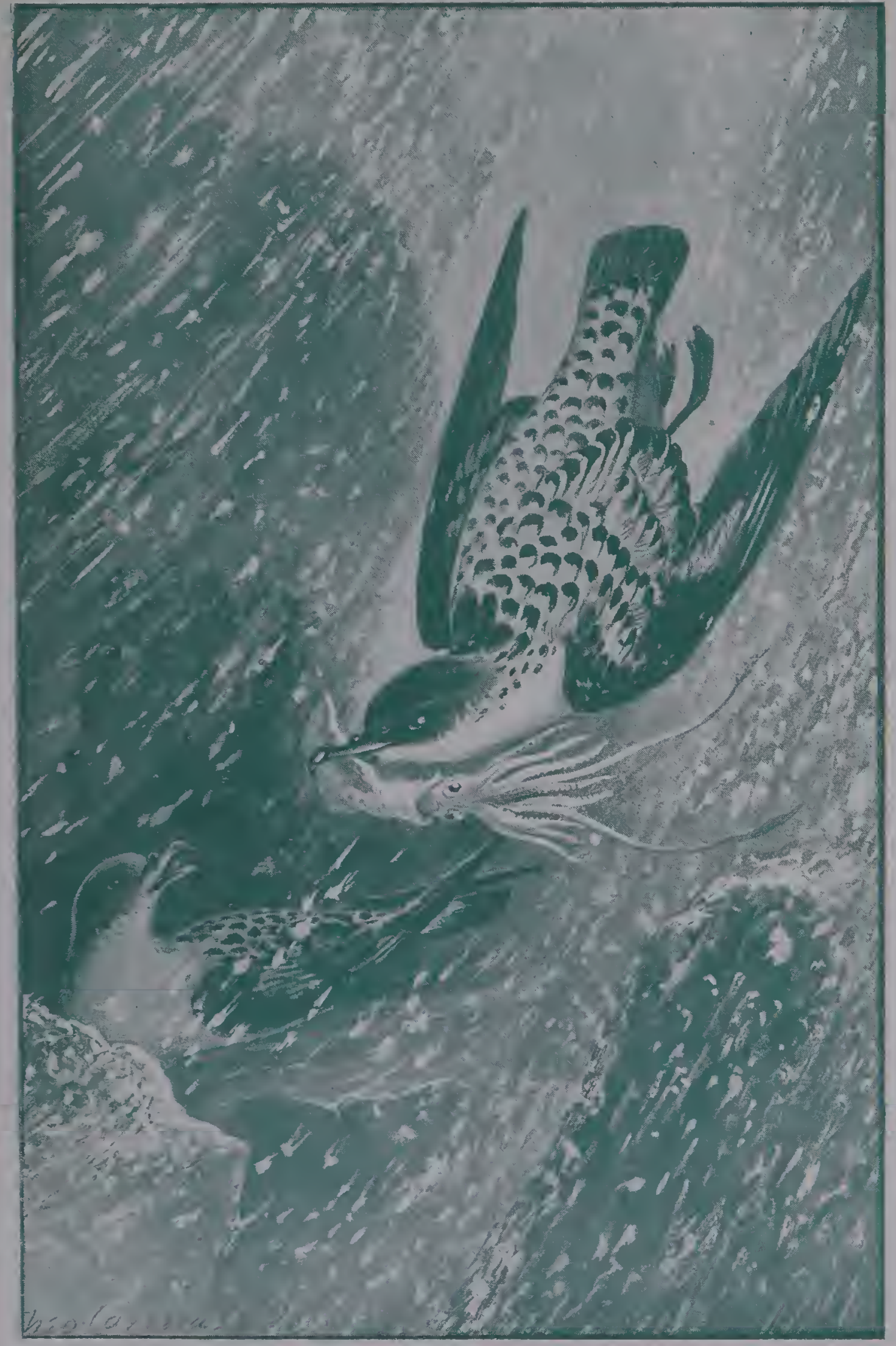

CAPE PIGEONS.

[i. face th. 3 t. 



\section{A Strenuous Husband 365}

bitterly cold air beneath, mingled with the flying sea-spray in the shape of large flakes of snow. By mid-afternoon the tempest was at its height, raging with utmost fury. And the pretty little hen-bird, fully occupied now with her maternal cares, looked appealingly at her sturdy mate, who puffed out all his feathers and chirped a brave response, as if he felt honoured with the commission to provide for his cherished one. Just a minute or two of careful preparation by sleeking down the close-lying feathers, a quick caress, and with a sudden fluttering spring he was gone, passing out around the precipitous rock barrier almost like a larger snowflake caught in a returning eddy and whirled backwards out to sea.

Here he was in the very heart and tumult of the storm, and no flap of his wings was needed, only careful and instinctive steering in order to keep in the right place for the reception of the propelling force to carry him whither he would go. It was a strange and strenuous quest. Now poised awhile in mid-air so thick with snow and spindrift that the seething ocean only a few feet beneath was invisible, now darting confidently along the green curve of a monstrous sea, unheeding the curling snowy crest above his head. Anon a meteor-like dash into the creaming smooth between the hollow of one sea and the broad round shoulder of the next, a poise with swift fluttering wings like those of a butterfly hovering over a flower in the momentary calm, a sudden plunge into the whirl, and forceful descent into peace, a delicious mouthful and a triumphant return. And all the while the keen black eyes never ceased their quest or grew weary. For over an hour this fierce search for needful food continued at utmost strain, then suddenly the brave little bird shot into the air from a wave-trough, 


\section{Cape Pigeons and Whale Birds}

a large squid squirming in the lethal hook of his beak. Almost instantaneously he got his bearings, and like an arrow from a bow, with drooping wings, but driven by the full force of the gale he sped shoreward, round the rock, and settled quietly by the side of his patient mate. She gently opened her mouth, and into it he dropped his prize.

And thus in the midst of storm and stress the tiny pair took their annual vacation from sea-wandering, and the stout-hearted little husband his delight in ministering to the wants of his dear partner, at present incapacitated from bearing her part in the ordinary business of daily life. He was supremely happy, for who can doubt that, at times like these, even what we are pleased to call the lower animals realise fully that it is more blessed to give than to receive? And she was happy too; for clasped closely to her soft, warm bosom were four precious treasures, smooth, rounded morsels of herself, upon which she gazed with eyes humid with love, as she turned them so that the sand beneath, though warmed somewhat by the overflowing heat of her maternal breast, should not chill them and frustrate her fond hopes. The quiet hours sped on, marked now and then by a heavenly day of tender blue above and placid sea beneath, teeming with easily won food. But whether fair or foul, the sweet marital solicitude of the cheery husband never failed, any more than the motherly patience of the little mother.

And then came the climax of joy, when four odd little balls of down with wide-gaping throats suddenly appeared, and demanded with one querulous voice, ' Food, food, food.' Indeed, the father, now somewhat doubtful of the magnitude of his task, had all his work to do, and do as he would he could not quiet 


\section{Family Duties Completed 367}

that hungry wail, except at night, for more than a few minutes at a time. But gradually it became possible for his patient partner to accompany him for a little while, then for longer, until finally the whole family might have been seen out upon the restless billows, the children being taught their life-lesson. Then, as is right and inevitable in the lower animal kingdom, the natural affection of the offspring waned as the latter became fit to fight life's battle unaided, and one fine morning the faithful pair flew northward, while their children took independent paths and went their several ways. 


\section{CHAPTER XXV}

\section{THE PETRELS}

DROPERLY speaking, several members of this great family of marine birds have already been dealt with by me, under the heading of albatross. But I am not a stickler for adhesion to any scientific division of birds into their varieties, and in considering the Petrels my mind is mainly fixed upon one species only, the tiny creature known as the Stormy Petrel, or to sailors most affectionately and inconclusively as the Mother Carey's Chicken. Why Mother Carey or why chicken is a mystery. Who Mother Carey may represent in the seafarer's mind I really cannot imagine, unless she be Davy Jones's aunt; but even so, to compare the Stormy Petrel with a chicken, either Mother Carey's or another's, has always seemed to me a great error of judgment. I know and love chickens thoroughly, but between them and the Stormy Petrel there is not one single point of resemblance, except that they are both birds. For the chicken is essentially a domestic creature, delicate, full of liabilities to ailments, needing great care and a snug roosting-place every night, if it is to be kept alive.

But the Stormy Petrel! Tiniest yet sturdiest of all sea-birds, ranging all over the wide, wild ocean, lilting fearlessly under the curve of a mighty Cape Horn sea, or skimming swallow-like over the glassy surface of the Equatorial Current; equally at home 



\section{A Lovable Sea-Bird}

on the weather scarp of a frowning iceberg, or around the pleasantly lapped beach of a coral atoll in mid Pacific; cheery, indomitable little waif, who with a heart as big as a grain of mustard seed could help loving you ? I could not wish the Bible other in any respect than it is, but somehow I have always longed that mention of the Stormy Petrel had been made in it. I rejoice to note the gentle Saviour's reference to the sparrow, to the dove, to the hen gathering her chickens under her wings; but I have never seen the Stormy Petrel flitting between crest and hollow of the mighty storm-waves in mid-ocean, when the great ship was being tested in every fibre of her build, but I have thought how much I should have liked to see that dear wee brave thing mentioned in the best of all books.

The Stormy Petrel (Procellaria pelagica) is a blackand-white bird of about the bigness of a thrush. Its wings are somewhat broader and sturdier than those of the latter bird, and its legs are longer-very long, in fact, in proportion to its size for a sea-bird. With the tiny webbed feet attached, they look as if made of black silk, and they are much more in evidence than those of any of the other pelagic birds, from an inveterate habit this Petrel has of stretching them out one after another, and just touching the water with them as it skims over the surface. For the Petrel does not fly high; no one ever saw a Stormy Petrel twenty feet above the sea unless it had been taken there, or was at its nesting-place, of which more anon.

Its principal characteristic is, I think, insusceptibility to fatigue. It does seem to have solved the secret of perpetual motion. In the course of fifteen years' voyaging, scarcely a day of which while at sea has passed without seeing these dear little birds, I 


\section{The Petrels}

have never seen one at rest. When feeding they do not settle on the sea; they hover over the wave and peck at their food, whatever it may be, much as a butterfly hovers over and sips at a flower. But the idea of resting upon the sea-surface never seems to occur to them, either by day or by night; for on a fine night in the middle watch-that is, from twelve to four--I have often watched the little dark shapes still flitting around, and heard, by listening closely, their low, twittering cry. This faculty alone would in so small a bird have given them a mysterious importance in the eyes of sailors, but in addition to that there is the fact of their constancy to ships everywhere. There are parts of the ocean where no birds but these are ever seen by the sailor; but I have never sailed anywhere, from Behring Straits to Antarctica, from Labrador to the Crozets, where I have not seen these little nomads of the sea. Of course, and I am rather tired of pointing it out, they, like the dolphins and fish, cannot accompany a swift steamship as they used to the leisurely wind-jammer, and in consequence future generations of seafarers will not know them at all-a very serious loss.

Naturalists declare that the Stormy Petrels in one ocean differ from those in another, while at the same time admitting that varieties from the Southern Pacific have been seen in Britain. Common sailors like myself prefer to believe that all this nice division into sub-fanilies, except for purposes of high science, has no value, and, indeed, very often we know that varieties have been tabulated between birds and fish of exactly the same character on account of some little peculiarity. One property of the Petrels, both large and small, has often been noted, their peculiarly musky smell, which extends to their eggs both outside 


\section{An Universal Scent 371}

and in, and may be recognised, no matter how long a period has elapsed since those hollow shells were added to the collector's cabinet.

Here I feel that it may be pardonable to digress for a few lines into considering the extraordinary fact of the universality of the scent of musk. On shore we are, of course, very familiar with it in its most delicate and delightful form, namely, that emanating from the pretty little plant, Mimulus moschatus, which will, with such slight encouragement, perpetuate itself year after year, and make the whole garden fragrant on summer evenings, especially after a light rain-shower. But for the needs of the perfumer the Himalayas are scoured in order to secure the musk pods of a certain kind of deer, which are so intensely odoriferous as to induce bleeding at the nose in many people who take an incautious sniff. The musk rat's tail, not even his scent sac, but his tail, will suffice to perfume a drawer for a musk lover for many years; in fact, once that scent is diffused it is improbable that the receptacle containing it ever loses it again. The cruel and hideous saurian that slimily awaits its prey at Indian village fords, in South American creeks, and Australian backcountry brooks is redolent of musk, pungent, nauseating, and never-to-be-forgotten odour that it is. The marvellous ambergris of the sperm whale, although only faintly smelling of musk itself, has certainly one quality amidst all the fabulous ones credited to it, of enhancing tenfold the power of any perfume to which it is added during the process of distillation. And any one who has ever had occasion to use a tube of sepia or stick of China ink, has probably tested its genuineness by smelling it, the faint yet penetrating odour being immediately apparent. 
Now as far as the genesis of musk in land animals is concerned I am unable to offer any opinion. But the power of ambergris, the scent of sepia, the muskiness of Petrels and their eggs, are only to be referred to one origin - the squid or cuttle fish in all his varieties, and how numerous they are let Mr. Edgar Smith, the erudite curator of the mollusca at South Kensington, tell you-I cannot. Again and again I am consciencesmitten at having ever said a word against the squid, for at every turn in discussing the lives of the DeepSea People aerial and marine, I find that without the squid the other creatures simply could not be. $\mathrm{He}$ is the basis, as it were, on which they are built. This is most especially the case with regard to my tiny friend the Stormy Petrel. So feeble, so small is he, that any competition with the ordinary sea bird in the universal struggle for food, or any capture of fish in mid-sea, are alike out of the question. But the languid Loligo, the little squid of an inch or so in length, is always handy on the surface, easy of capture by even so slight and weak a bird as the Stormy Petrel, and in this way the latter little hungry creature is fed. More times than I can remember I have seen the little fellow in the midst of its dartings to and fro in the wake of our flying ship, well on one side of us, where it could not have been possible for anything dropped from forecastle or galley to float, pause suddenly, and with fully stretched legs and quickly fluttering wings reach down to the creaming surface, and snatch something therefrom with a shrill cry of satisfaction. That something was invariably a little squid, a boneless succulent morsel created to that end, without prevision or possibility of feeling pain, and consequently perfectly happy even while in process of transition into other forms of usefulness. 



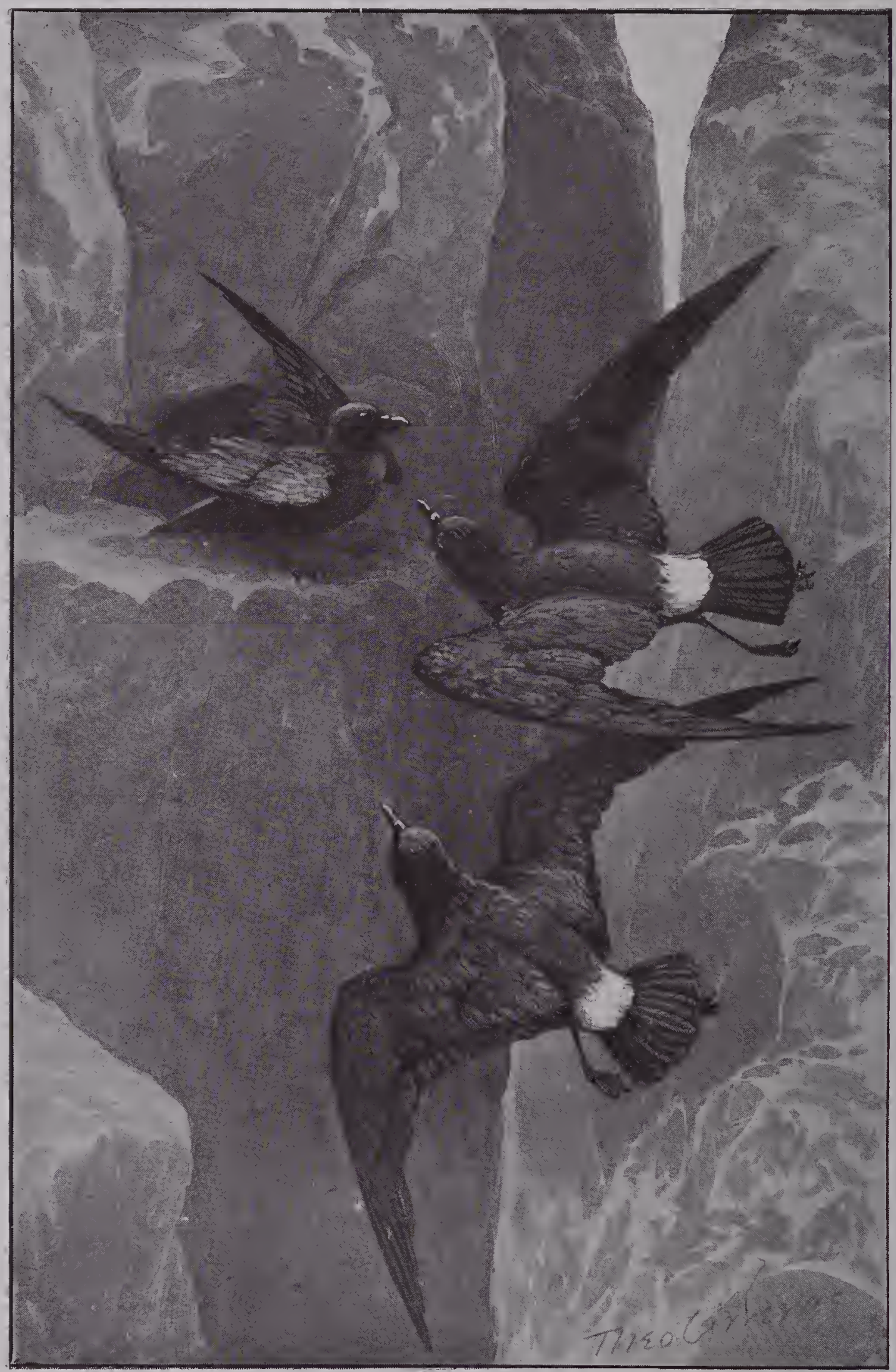

STORHY PETREL TEACHING ITS YOUNG TO FLY.

[To face $p$. 3 ร3. 


\section{The 'Foul' Petrel}

For a brief space, and before entering into the family history and sea-going career of the tiny wee wanderer I love so well, I must pay the compliment of notice to an almost unique member of the family, the Fulmar Petrel. Its front name indicates to those conversant with Scottish idioms the prevalent characteristic of the bird. The word has been crudely translated by the practical Americans into an unpleasant but entirely appropriate Anglo-Saxon equivalent, Stinker. The reasons for this coarse cognomen is self-evident; the bird is really the skunk of the feathered world; and on the principle, I suppose, that the more unpleasant the remedy the more certain the cure, the islanders of St. Kilda seize the living bird and squeeze from its throat a little oil, a tablespoonful or so, which is considered to be an infallible remedy for chronic rheumatism. I will not say that the remedy is worse than the disease, but certainly those using it deserve to get cured. It almost helps one to understand the Chinese predilection for the application of the moxa, a red-heated iron, to an inflamed part for curative purposes. But Pennant, that entirely unreliable but most delightful writer, says, that no bird is of such value to the islanders as this. It supplies them with oil for their lamps, down for their beds, a delicacy (!) for their tables, and a medicine for their distempers.

In the Southern Seas among whalemen it is notorious as being the only bird which, in the midst of waiting thousands, will fearlessly perch upon the body of a dead whale, and begin tearing at the skin, in the hope of getting an advance subscription to its dinner fund. It comes down with a thud, and hence the terrific threat of the Yankee whaling officer: 'I'll 'light on ye like a Stinker on a carcase.' Not 


\section{The Petrels}

even the most enthusiastic of Nature lovers could truthfully profess to see any beauty in a Fulmar. Its colours are nondescript, dingy; its beak huge and cabbage-water green. In numbers south of the Line it is to seek, only up north, in those untilled regions of cold and storm, does it flourish in vast flocks, and provide a patent medicine for St. Kildians. Among the almost inaccessible rocks of the Hebrides it breeds, but nowhere in such numbers as at St. Kilda, affording to the hardy lonely islanders, who have long learned not to be fastidious, a never-failing means of livelihood. Although one would have thought that a Fulmar's egg for breakfast would act as a sure discouragement against any further experiments in the direction of egg eating, from the exceedingly rank and inimitable odour thereof, these dainties are so highly thought of by the St. Kildians that the collecting of them forms the principal occupation of the islanders. In it they continually risk their lives, as the bird roosts in the most inaccessible places, on ledges a few inches wide, worn in the faces of perpendicular or overhanging precipices. In like manner also do the islanders collect the live oil from the bird's stomach; just a few teaspoonfuls of clear but intensely fetid oil, which the bird vomits when seized, into a vessel held for the purpose. Buc all this is a many-times told tale, and one perhaps which is not strictly within the limits of my subject. It is exceedingly strange, however, that while the northern Fulmar is so very abundant, and is, moreover, never seen far from shore, his southern brother is a solitary bird as far as his own kind go, and is met with as far from land as any bird can get.

And now, as it would only be tiresome repetition to go over the small difference between the varieties 


\section{Perpetual Motion}

of Procellaria, and besides quite contrary to my usual rule, I gladly return to the Mother Carey's Chicken biographically, giving first of all some few details of my own personal acquaintance with them, ever gratefully remembered. How timidly on my first voyage did I ask the mate, a big gruff Norwegian, what those pretty little birds were. How could I tell that I was committing a serious breach of etiquette? He replied very gruffly and unintelligibly, 'Stern Pitter.' I ventured to say, 'What ?' and was at once bidden to 'shut up' and look out for myself, as if he had been insulted by my not understanding him. I took the hint and asked no more, nor did I learn that 'those little birds' were Stormy Petrels for a very long time, although, like other sailors, I of course knew them as Mother Carey's Chickens.

But they were always a source of never-ending delight to me while at sea, and of wonder too, for I could not help feeling that they had indeed solved the great problem of perpetual motion ; never needing or desiring rest apparently, and always sticking to the same ship to which they had taken a fancy in calm or storm, whether flying before a gale or stagnating through many days of windlessness, as was common with the old sailing-ships. I was glad to see how the sailors generally regarded them as birds of good omen, and in nowise to be meddled with. Indeed, in my day not a few seamen really looked upon them as the spirits of departed sailors, who, never weary, flitted over the bright pure sea eternally. But then many seamen thus rigarded the albatross also, yet I never saw the same sincere reluctance to do them harm as was always evinced towards the Stormy Petrel.

Once I saw a man, a second mate, wearying for 


\section{The Petrels}

something to do, catch one of the pretty creatures by means of thickly-tarred roping twine attached to a bait of pork, which was hooked on to the end of a fishing-line. The little bird, fluttering over the meat and continually touching the water with its feet, as is its wont, got them entangled in the sticky twine, and was hauled in all bedraggled, its bright vivacity gone, and presently lay panting and helpless in the grip of its silly tormentor. Fortunately the captain coming on deck at an opportune moment, saw the shameful deed, and gave that second mate such a wigging as I hope did him good. It was the only time in my life that I ever rejoiced to see a subordinate on board ship receive a public reprimand.

Even to the last day of my sea-service I was unable to divest myself of the feeling, when watching the movements of the wee Petrel in a gale, that they were sent to the sailor as an object lesson of the all-pervading care of God. The mighty ship in a heavy storm does look so insignificant in conflict with the ocean, all man's skill and genius and courage count for such a little against the immeasurable power of His sea, and is so dependent upon the faithful co-operation of all concerned, that it comes with a wonderful relief to study the tiny wee seafarer alongside coquetting with the wildest waves, and untroubled by the fiercest storm. In nothing, I think, under heaven is the wisdom, love, and care of God more manifest than in the behaviour of a Mother Carey's Chicken in a tempest. But let us associate ourselves more intimately with a pair, for only by so doing can we realise what a wonderful thing their life is.

That was a very lonely morning when I discovered that my father and mother had both left me. Ever since I first found myself in the cosy little rock tunnel 
in Kerguelen Island, my only sensation that of being ravenously hungry, I had never been out of their sight, one or the other of them, for an hour by day or by night. At first they used to come and go almost continually, always dropping some delightful morsel down my gaping throat, and scurrying away through the tunnel again as if they had not a moment to spare. And they would hardly be gone before I began again loudly lamenting my lack of food.

But let me tell you about my home, for I never forgot it in all my long journeyings; when the time came at the fall of the year for me to return thither, I did so over the thousands of miles of intervening sea as straight as the wind blows over those mighty open spaces. As perhaps you know, Kerguelen is, for those people who use the land continually, just a desolate mass of rock and sand, with hardly a sign of anything growing but birds and seals, far down the slope of the Southern Sea. At one place there is quite a mountain rises straight up from the sea facing the south, but this mountain is split in half; right in the middle of it there is a crack as wide as a porpoise that runs through from the sea to a quiet little plateau beyond. All around this little flat patch, which is floored with black sand, there are round holes in the rocks which run in about ten times my length and widen out a little when you get as far in as you can.

Here, in this cosy shelter from storm and wind, which I never felt the need of at any time after I left it, I first knew I was alive. And when first, after a long stay in that darkling warmth, I was lured slowly along the passage by my gentle little mother (I was so much bigger than she was) I trembled so that I could hardly move. You see, I had never before moved except in the tiny little hollow where I was 


\section{The Petrels}

born. But at last we reached the opening, and to my amazement and fear my mother floated away into space, leaving me shivering there, and watching her with starting eyes. Feebly I cried to her to come back to me, but she replied with gentle twitterings of invitation, in response to which I felt an earnest, an almost fierce desire to do as she was doing, to join her in those graceful airy circles that she was making.

Then my father flashed on to the scene. Where he came from I did not see, but there he was joining his entreaties to those of my mother, and every little while caressing her with his beak. Oh, how patient they were! It does make me ashamed when I think of the long time during which I resisted their invitions to join them, to try those new wings of mine, which indeed were working jerkily of their own accord at my sides. How many false starts I made, until at last, quite by accident it seemed, I found myself in the air, full of fear, but working my limbs frantically in obedience to some hidden, unknown, compelling power.

It is all a blur, all full of mystery, that first flying lesson. All I remember is that presently I found myself on the ledge at the mouth of the tunnel again, with a new strange feeling of triumph all over me, almost overcoming the trembling which had so distressed me. I was trembling still, but part of it was due to joy. After that, I was coaxed again and again to try those wings of mine, and no more food was brought into the tunnel for me. I found myself growing apparently stronger, lighter and lighter. I did not know, of course, that the latter was really the case, the mass of fat with which I was encumbered when first I tried to fly having become absorbed in my tissues, and muscle having taken its place. It 


\section{My First Lesson}

had been necessary in order to keep me warm when I did not move, but now as I needed it no more it had gone.

So day by day I became stronger and more daring, until, almost unthinkingly, I dashed out of the narrow opening between those mighty rocks and was on the glorious sea, my real, my splendid home. And in that wonderful moment I felt all the joy of living, the delight of being in my rightful place and master of my surroundings. - I felt eager to emulate my parents, to do what they could not do, although instinctively I followed their every movement. Another surprise, and an essentially pleasant one ; as my father swooped down the side of a wave, I saw him snatch at a little white wriggling thing there and swallow it. There was another by its side at which I dashed, seized it, and gulped it down. Delicious first morsel, how sweet it was to feel that I had gained it, and that all this wide feasting ground was mine!

For a few days this finishing portion of my education went on, I growing more and more impatient of being taught, until one day my father and I hooked our beaks into the same squid, a bigger one than usual, and I fought savagely with him for the possession of it. Unknown to me the parting of our ways had come. From henceforth he was no more to me or I to him than any two chance-met members of our family, and although we returned to our home that night it was for the last time together. I slept soundly till dawn, then waking to instant activity, as is the custom of all our people, sped outwards to sea to find myself, as far as my two parents were concerned, quite alone. As I have before said, for a little time it was very lonely. But soon the natural adjustment took place, pride in my ability to do as my parents 


\section{0 \\ The Petrels}

had done, even better than they, took the place of my first sense of loss, and I went on with my task of getting food whole-heartedly.

But now I felt no desire to return to that quiet little nook which had hitherto sheltered me. I did not feel the need of shelter at all. Nor did I feel the necessity of companionship. Blithely I fluttered from wave to wave intent on finding food, nor noting how the grim peaks of Kerguelen were fading, even from my keen sight. I felt as if I had just been released for a long, long holiday, the mighty ocean for my playground, abundant food at my feet, and the possibility of weariness withheld. Ah, I was so happy! I flew on and on, unheeding whither, taking note of an occasional lordly relation, a huge albatross, or a flight of Petrels of much greater size, but, as I noted with satisfied pride, far less vigorous than I, only with none of them did I speak or stay for one moment. What had I in common with them-I, the selfsufficient, the weariless one? They must perforce rest upon the waves now and again; I, never. They could not feed as I did, their great bodies disdaining the tiny succulent morsels upon which I feasted so royally, and I was glad, so glad.

When night fell and the sky darkened I still rejoiced; when the mournful wind began to wail over the great spaces, and the waters snarlingly rose in protest, I hovered twittering, content.' I was satisfied, why not they? Steadily rose the wind, higher mounted the waves, what cared I ? I was master of the whole wild scene, the tumult of the elements was but a lullaby, not to rock me to slumber, but to please my delighted ear, as, unconscious of effort, I still sped to and fro in the darkness of the great night.

By morning I was hungry so eager for food that 


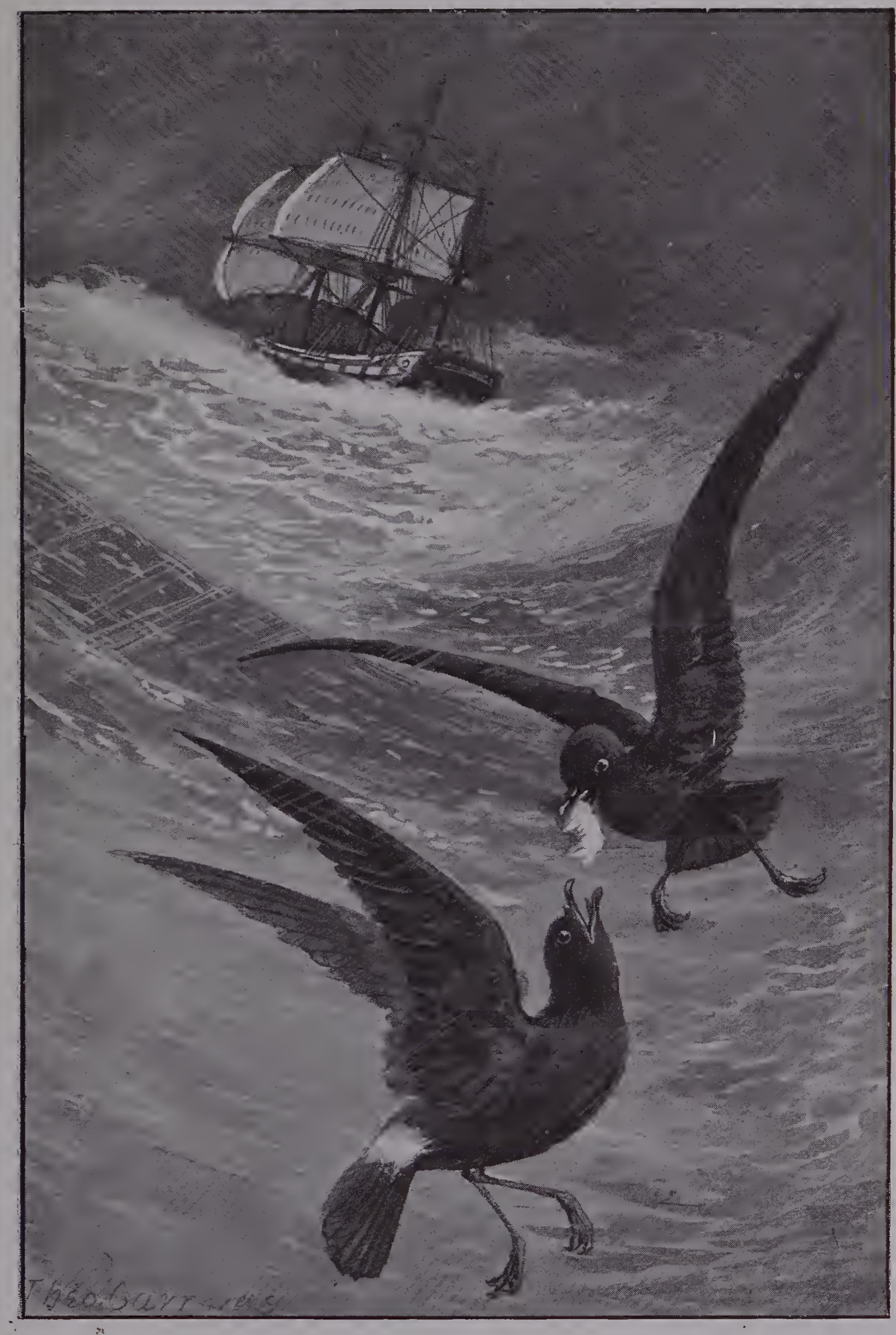

STORMY PETRELS.

[To face $p .380$. 



\section{Pride of Place}

all other sensations lay waiting. The storm was at its height, the sky nearly touched the sea. The waves rolled long and sullenly, unable to rise to their desired size, for the pressure of the wind held them down. The air was full of wetness, it was hardly to be known from the sea itself. But I was shut in from it all by a downy envelope, my body (you could hold three in your hand at once), hot, fully sheltered, palpitating with eager living. I skimmed along the hissing, curdling surface of the sea, eating my fill in peace, and utterly unheeding the war of wind and wave as I did so. But when my hunger was appeased I felt no slothful desire to fold my wings and sleep. Added energy, ecstasy of movement impelled me, and filled me with great content. The bliss of living possessed me entirely, and although not another of my kind was near, I felt no need of one. I was satisfied with myself for company.

But presently I saw, looming up through the gloom of the spindrift, a vast shadowy bulk which for the moment gave me a strange sensation of dread. I did not know it ; was it my island home that I had unknowingly come back to ? I drew nearer to it in spite of my fears, and then suddenly knew that I had nothing to dread. It was a ship, a great vessel being sorely beaten and battered by the mighty sea. How proud I felt as I saw that gigantic bulk straining to keep her place, quivering to the summit of her tall masts, and rolling in the seething smother like a dying whale, that I, whose body was almost as a grain of dust by her side, was so absolutely safe, comfortable, and free from all apprehension even of danger!

I saw men for the first time. Strange beings they were, tottering about that great thing as I did ere I learned to fly, evidently not at home, evidently very 


\section{The Petrels}

much at the mercy of that vengeful sea, and fully conscious of the fact. Poor men! I knew somehow that they would not harm me, knew too that I should here find food. Felt strangely certain that in some mysterious way we had been friends for many generations : that is, my forefathers had with theirs, and the knowledge had come down to me. So I fluttered about and about her, noting her every detail, and especially the half-admiring, half-pitying glances cast upon me by the men who stood clutching some support, all over her.

As I hovered around her my liking for her increased, and especially for the sweet, the delicious morsels which continually floated away from her in the broad smooth space she left as she drifted sidelong. I was very busy, happy of course, but kept fully employed because these morsels did not cloy, but rather tempted my vigorous, healthy appetite. And besides I felt prouder than ever, because I was sure that those strange beings were continually admiring me, and wondering at my familiarity with the terrible sea, which was so threatening to them. And then suddenly there came the great joy of my life. Had I been able to tell my experience to any, I should have said that my joy was full, complete, but I did not know.

As I fluttered around her for the thousandth time, I met one of my own kind. For the moment I was indignant. The ship was mine by right of discovery. Who else dare intrude, and by what right ? And then with a sweet, low voice the new-comer introduced herself. Oh, the exquisite sound of it! I flew to her side, I found her, she was mine. The climax to my joy was reached, it was love! First hunger, then fear ; succeeded conscious effort, sense of power overcoming, and now love. The sea, the sky, the ship, the food, 


\section{My Partner}

the power of unwearied flight were now all leading up and accessory to this, the greatest of all forces, overbrimming with delights, the all-embracing joy of love. Henceforth our desires were entwined. Did I find a delicious morsel ? it was hers, mine the exquisite pleasure of seeing her enjoy it. Did she call me to a new treasure of food floating by? oh, the rapture of sharing it with her! And when a little boy on the deck of the ship, the weather having moderated greatly, said to his mother, standing by: 'Oh, look, mamma, I believe that dear little bird has found a wee wife!' I could have screamed with delight, had it been in my power to do so.

In due time we tired of the ship, for when the breeze suited, and all her wings were spread again, she went steadily, straightly forward, so fast too that it became irksome for us to flutter round and round her, as we loved to. And besides, her company was no longer to us the pleasantness it had been before we became all in all to each other. Still, for long we flew side by side in perfect content, visiting many ships, seeing many new faces, and always happy, for we were never afraid. Our world seemed inhabited only by friends. We skimmed over seas that teemed with life under the continual sun by day and the tender violet of the sky by night, we saw many new landsand sheered off from them-what needed we of the land?

We lived and loved, and were happy because we did. Until there came a day when we both, having all feelings, not to say thoughts, in common, had the need laid upon us to go south again. We were then trying to be fond of a great ship that sped, unrestingly as ourselves, through the sea with an everlasting whirlpool behind that we did not like-I cannot say we feared 


\section{4 \\ The Petrels}

it. And with one accord we abandoned our pleasant fluttering to and fro. Side by side we stretched our wings and made haste, as never before, towards the bleak South, nor ever paused until once more we darted in between those mighty walls of rock, sheltering the tiny nook where I was born. As we did so I felt just one doubt lest it should be preoccupied, but I need not have done so. It was ready for us. My sweet one crept in, I following her, until, settling down, she cooed contentedly, invitingly, and I, nestling by her side, let all things slip away into deepest peace.

When I awoke my dear partner did not stir. I knew, and, caressing her, hastened away, intent upon what I understood as love's privilege to provide for her. Out between the rocks I darted, found what I sought, and returned. It was another added joy. Oh, I was so happy! Of all the delights I have ever known-and my little life has been overflowing with them-there have been none like this. I worked incessantly, untiringly to feed her, my patient love. I did not know why, nor could I enquire. But she sat in darkness waiting for some blissful event, I her only sunshine, her only means of support, the one whom she trusted, and with reason. I could have wished that time to have lasted but for her. I did feel the need of her sweet company out upon the sea. And yet I was content, for I knew in some strange manner that all was well. But when she rose to meet me, as one morning I returned with full beak for her, her little velvety body swelling with conscious pride, and I saw a strange gaping bunch at her side, I felt a shock. Had I a rival? Indeed I had, my son. I had no joy of him, for I felt he separated me from her. She was all I needed, no third. Still, with her I 


\section{Rewarded at Last $\quad 385$}

laboured to teed him, to teach him, to launch him in life. And at last I was rewarded, when, finding he was well able to fish for himself, we two sped northward again to renew our happy journeyings to and fro upon the lovely sea. 


\section{CHAPTER XXVI}

\section{BOOBIES AND PENGUINS}

U

NLIKE any of the other birds of which I have been writing, the subjects of the present chapter are really not pelagic, that is, they are birds which must find a rest for the soles of their feet upon something hard every night, preferably at their proper homes, although that is sometimes impossible. An almost invidious selection has now to be made, but one entirely necessary, since the varieties of such birds are very numerous. And I have endeavoured to surmount the difficulty by only taking those that are fairly familiar to sailors in out-of-the-way parts of the ocean, and almost unknown to the majority of landsfolk.

First in my mind comes the Booby, which is a species of gannet, but varying in several important particulars from the pretty, well-known gannets of our own coasts. It has a reputation for stupidity which I feel is hardly deserved, and is really only given upon very slight grounds. But in consequence of this reputation it has obtained this somewhat opprobrious name, first by the Spanish seamen who, trading in the Gulf of Mexico, made its acquaintance, and conceiving but a low idea of its intelligence called it 'Bobo' or Stupid; hence our word Booby, both words deriving from the same root.

Perhaps the sole reason for the idea of the poor 


\section{Stupidity?}

bird's stupidity arises from the fact that when it alights upon any portion of a ship, as it often does in the vicinity of its home, it will sit still and allow itself to be taken, although it has only to tumble off its perch to be free and far out of the reach of the marauding hand of the sailor. But there it sits, with its full dark eye staring full at its enemy, apparently hypnotised into insensibility, and only when it is grasped and its doom sealed does it begin to struggle vainly to escape. Really the reason for this immobility is fairly obvious, although I have never seen it stated. Of all the sea-birds there are none that toil so tremendously at their business of food-getting as the gannets, and the Booby is no exception to the rule. The big, somewhat ungainly bird, with his long straight beak and his gawky wings flapping heavily and continuously, is, as I have said, a fairly well-known object off our north-eastern coasts, and most observant visitors have admired the wonderful way in which, while flying in utmost haste along at a height of over a hundred feet, he will suddenly fold his wings and drop, beak first, with a tremendous splash into the sea, emerging almost immediately after with a fish in his beak, and literally fighting his way into the high air again.

Now, no other sea-bird, not even the lively gull, or the ungainly cormorant, labours like this for its living. The poor Booby oftentimes finds itself far afield and quite weary, when a tempting opportunity for a perch presents itself, of which it takes advantage, and having done so, seems quite unable to exert itself further for some time, even in the presence of the most imminent danger of capture. Why it should prefer the yards or booms of a vessel to rest upon to the sea at such times is a thing I do not pretend to understand, 


\section{Boobies and Penguins}

but the fact is that it does do so in preference to resting on the water; a thing I never remember to have seen one doing.

There is perhaps another and more convincing reason for the Booby's apparent stupidity. The lonely islets and cays which it frequents are seldom visited by man. Being naturally of a confiding nature, and getting little opportunity of learning how unsafe it is to place any confidence in the lords of creation, it is unprepared for the danger of capture which attends it upon alighting upon any place to which he has convenient access. And why sailors should take the poor birds I do not know, except that the temptation to lay hold upon a bird that is unable or unwilling to fly away is almost irresistible to most men. For the Booby, like all sea-birds, is anything but good eating, being rank, tough, and oily; while as a pet he is of no use at all. And I am ashamed to say that all I have ever seen taken on board ship were presently, after a period of maltreatment, flung overboard, a piece of cruel waste for which there can be no possible excuse.

My first acquaintance with the Booby dates back to my first voyage, as a small boy in my twelfth year. Of course, I do not know the exact part of the sea in which we were cruising, but I know that we were at no very great distance from land, for we were sailing-not steaming-from Demerara to Santa Ana in the Mexican Gulf. And one night, being becalmed, one of the men pointed out to me a dark object on the cat-head clearly outlined against the moonbeams on the sea. I don't know why, but in those days any item of information conveyed to me in a whisper with an air of mystery always made my heart pump furiously ; and my feeling, though perhaps not exactly fear, was not at all pleasant as Joe stole away from my side towards that dark 


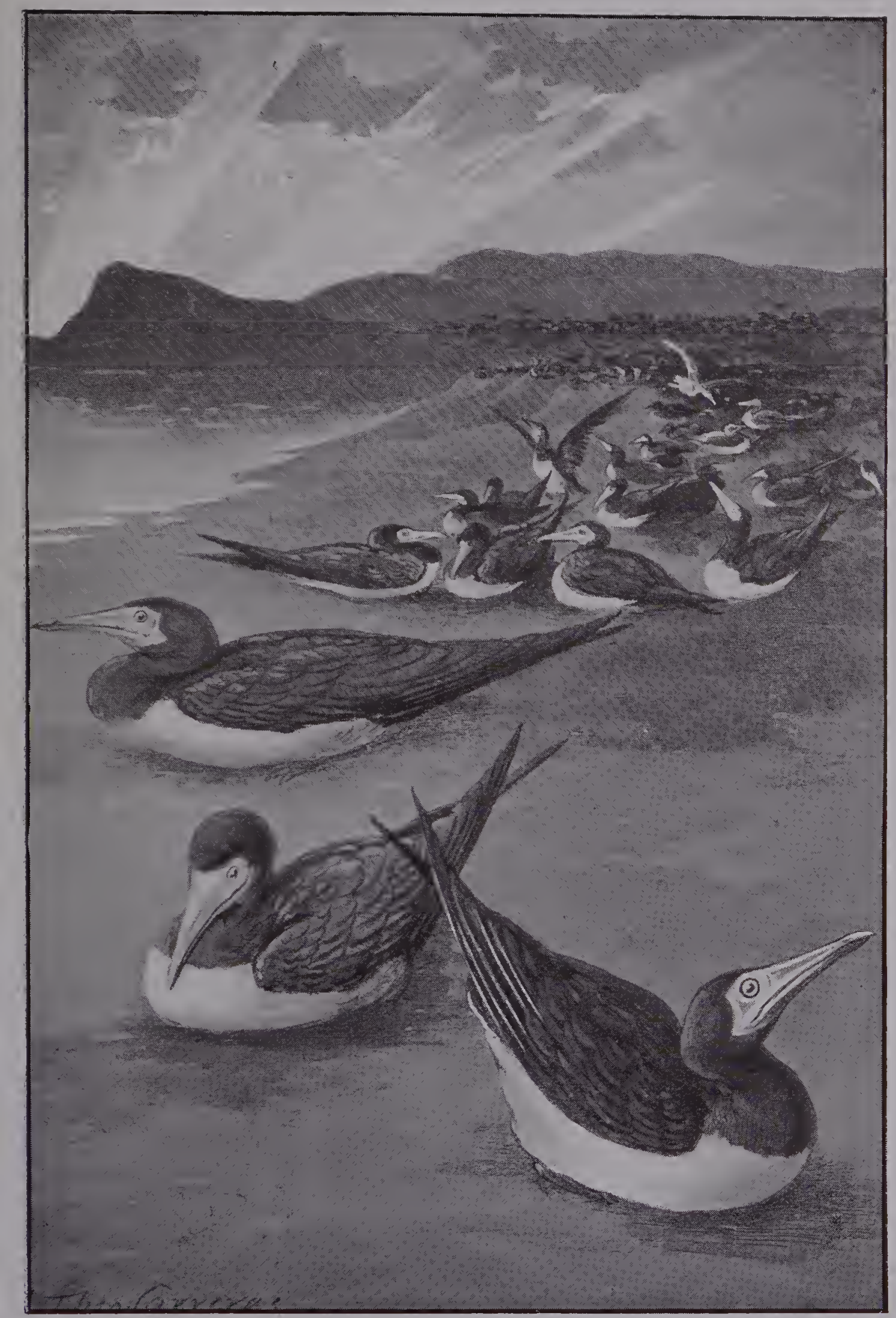

A COLONY OF BOOBIES. 



\section{A Booby Farm}

excrescence on the cat-head. I held my breath as he crept nearer to it, and was suddenly relieved to hear a loud squawking, almost like that of a suddenly irritated parrot. Joe returned to me, exhibiting to my delighted gaze a large white bird pitifully struggling to be free. Then the other men came around, and there was a long and voluble conversation about the bird, of which I wearied and went away to sleep. When I again saw the captive it had been skinned, but to my astonishment nothing was done with either skin or carcase-after a short time they were both flung overboard.

Less than three months afterwards, in another ship, I awoke one morning, to find by the strange sounds and motions made by the vessel that she had run ashore, and when morning dawned I saw that many Boobies and men-of-war or frigate birds were hovering about us, the former filling the air with their shrill cries, and the latter calmly and apparently contemptuously watching us. Two days after we all left the wrecked vessel (she was broken in half) for good, and landing upon the little sandy cay which formed the apex of the vast coral reef upon which our ship had been wrecked, we found almost the whole sandy area in possession of these birds, Boobies. They did not venture over to the rocky side, for reasons which will appear later. It was a most surprising sight to us, to me especially, a city-bred boy, to see the wide beach covered with vociferous birds sitting on eggs lying in small depressions in the sand, or going to and fro, either waddling or on the wing, but none evincing the slightest fear of us. It was an entirely new sensation to have a bird as big as a duck, but with twice the wing-spread, come flapping busily along and not trouble to avoid one; indeed, I was knocked down 


\section{Boobies and Penguins}

twice, and afterwards opprobriously assailed by the infuriated bird for getting in her way when she was hurrying back to her eggs. Of course the eggs were a great treat to us-when did ever a sailor, rightly constituted, feel indifferent to the sight of an egg ?and we started to gather them, careless of the feelings of the mother Boobies. But if they lacked sense they certainly did not want courage, and those of us who had not sea-boots on, soon found that a trouser-leg was but poor protection against a driving blow from a Booby's beak. So the majority of us retired to look for sticks (of course no such ridiculously sentimental notions weighed with us as consideration for the feelings of the parent birds), and meanwhile the din was deafening. There were many thousands of birds, and every one of them seemed to be protesting with all the power of his or her lungs against this piratical invasion of a peaceful and inoffensive colony. I know that I felt as if I should never recover my hearing again.

Presently, having armed ourselves with sticks, we returned to the charge, and gathered many eggs; at least I say we, but I remember that being barefooted I merely hovered on the outskirts of the war, and bore the eggs away as others collected them whose feet were better protected against the Boobies' beaks than mine. I am sorry to say that in the struggle for the possession of those eggs many of the protesting Boobies were killed. Their bodies were brought into camp and flung down, a doleful heap, for some one to prepare for eating. But as the helots who were invited with many unnecessary sea-compliments to undertake the task sensibly observed, 'We've got plenty of good grub, an' there's plenty more for the taking, why bother about getting meat ready that nobody will eat ?' So there was more waste. And even the eggs, 


\section{Awakening Morn 39I}

gathered with so much loss of life (to the mothers), were hardly eatable to men who could get other and more tasteful food, as we certainly could then. There were eggs on the island, delicious, plentiful, large, but they belong to another story. Only the honour of finding them was mine, and mine alone.

Next morning I was awake and astir before daybreak, not because I then loved early rising, but because my sleeping-place was so miserably uncomfortable that I laid no minute longer than I could help. Who would, wedged into a long row of men, as sardines lie in a box, with a lump of coral the bigness of a man's head in the middle of one's back, by no means get-atable because of the long cloth of canvas over it held down by the bodies aforesaid. So I rose and strayed along the beach, watching the tremulous shadings of coming light in the sky, and listening to the murmur of the wavelets against the sand and the low beginnings of conversation among the birds. And then my attention was divided between the glory of the new day, a never-ceasing source of delight in the tropics, and the strange sight afforded by the host of busy birds, parents present and prospective. As it grew lighter their cackling grew louder, until, when the full day swung like a fanfaronade of silver trumpets across the waiting concave of the heavens, they all burst into a deafening chorus of cries, apropos of nothing as far as I could see. Of me standing close before them they took not the slightest heed. Those with young ones hatched poked at and preened them with their long beaks, preparatory to leaving them, and those with eggs only just laid took a parting glance or so at them, preened themselves, and flew-clean over my head, with rapidly jerking wings towards their free and common hunting-ground, the teeming sea. 


\section{Boobies and Penguins}

I was so fascinated by the busy scene that for long I did not stir, and so was able to witness the return of some of the mothers, who had been almost immediately successful, with quite large fish in their mouths, which, dropping among their screaming young, they proceeded to distribute, at the same time keeping a bright look-out upon those conscienceless, lazy marauders who continually endeavoured to steal.

In an hour after full day they were practically all away, although, as I have said, occasional stragglers, having been rewarded with an early catch, came dropping in with their prizes for their families. Then came my shipmates, bent on egg-collecting, but I was glad to see that now they were a little more discriminating than on the previous day. They examined the eggs to see whether they were edible or not, and when they found a couple of helpless unfledged ones in a hollow, they merely gave them momentary discomfort by taking them up and examining them; they did them no harm. Together we took a thorough survey of the great space occupied by the nesting Boobies, and admired the business-like way in which the parents provided for the needs of their offspring, also the ease with which the food was obtained. The sea over and adjacent to the reefs literally swarmed with surface-fish just of a convenient size for the birds to handle, and they, the birds, never seemed to flag in their earnest endeavour to get their living and provide for those dear to them. Of course they were all very much alike, but after a time of careful watching I was able to single out those who were most energetic, finding that even here, where instinct ruled, there were degrees in industry as well as among men.

The male birds had a reservation of their own, and seemed to be held in considerable disfavour by both 
hatching and nursing birds, as if they had contracted themselves out of any right to occupy the same space. They certainly did nothing towards the maintenance of the families, being apparently fully occupied in providing for their own clamorous needs. The mother birds had their domestic cares to attend to as well as the providing, which led me to think more than scornfully of the male Booby as regarded his affections, especially comparing him with the deep-sea birds of my acquaintance, but rather highly as regarded his iniquitous cunning, which certainly did not justify his contemptuous name. But there was one recurring circumstance which I continually noted, about which I have some trouble. It does not appear very clear whether I should mention it here or in a later article, but I do not see how I am to do the Booby full justice unless I make some allusion to it at present, and so I fear I must do so even at the peril of repeating myself later on. I noticed repeatedly that as the mother birds were returning at full speed to their nests with a load of food (I say 'nests', although, as I have noted, the eggs and young ones just lay on the open sand), they often evinced signs of great alarm, and dodged about at full speed, sometimes rushing right out to sea again.

The reason was evident. High above the busy birds fishing there hovered black wide-winged birds, whose province it was apparently to live upon the labours of others. And when they saw a homewardbound bird flapping heavily towards the land, one of them would by easy stages, yet with amazing celerity, descend from his lofty plane, drawing nearer and nearer to the labouring Booby like a kestrel descending upon a pigeon, but in far more leisurely fashion, as if perfectly confident of success. 


\section{Boobies and Penguins}

The unhappy matron, foreseeing the sacrifice of her toil and her fledgelings' hunger, would strain every nerve, her angular wings working furiously and her whole body trembling with evident anxiety, in striking contrast to the calm fateful approach of the black descending shadow. But dodge as the Booby might, exert herself as she would, there would come a time when, like a thunderbolt, the hovering thief would descend, his wings nearly closed and his tail widespread. Then, alas! poor Booby, there was nought that she could do but drop her treasure and flee for her life. And the graceful villain with one great swoop would catch the fish ere it touched the water, and soar skyward again unconcernedly, as if it was part of the appointed scheme of things that Booby should toil and he should calmly reap the fruit of that toil. Booby meanwhile was scouring the sea again in search of the much-needed meal for her family, and with who knows what ever-springing hope that next journey she might evade the ravishers of her little ones' food.

Such a sketch as I have endeavoured to give of the life of the Booby may be accepted as applicable to all these birds wherever they live. They are never to be seen very far from land and never exterior to the tropics, for warm weather is a necessity to them. Their homely virtues, as will be seen, are many, if their beauty and intelligence cannot be rated very high. And, principally I think from a fellow-feeling for common-place folk, I have dared to strain a point, and include the essentially homely Booby in this record of the statelier denizens of the deep-sea spaces to which truly it does not belong, but still cannot be reckoned as one of the familiar sea-birds to any others but sailors. And for reasons which I am tired of reiterating, even sailors, by reason of the displacement 


\section{Miscellaneous}

of sails by steam, will soon as a class know the fussy homely Booby no more.

About the et ceteras I have my doubts. One class of birds, which I do not possess sufficient acquaintance with to make them the subject of a separate chapter, I am leaving to the end of this chapter. I allude to that curious tribe, the Penguins. But of other truly deep-sea birds there are really none. The great gull tribe in any of its varieties never venture far from land in the comparative sense, the petrels deserved (and have got) a section to themselves. Even essentially land birds are often found at tremendous distances from the shore, having been whirled away most unwillingly from their course while journeying from winter to summer lands, which would never happen to sea-birds whose habits keep them in daily touch with the land. Nay, and I do not think any apology is needed for introducing the matter here, I have actually seen, not once but several times, fluttering about a ship becalmed in the centre of the broad Atlantic, an ephemeral butterfly. The sight set all hands a-wondering whence the pretty waif could have strayed so far, and some even broached the idea that the chrysalis from which it came had lodged on board in some convenient but inconspicuous place, and had just been hatched out. But they were, as I think, very properly laughed out of court. In mid-ocean too, I have seen, and that where even the strenuous gulls did not appear, a little flight of swallows board the ship, as a haven of rest in the midst of the wide and to them inhospitable sea. I shall not soon or easily forget how, coming weary and hungry from the wheel one morning at 2 a.m., I went to the breadbarge, which hung from a beam in the forecastle for fear of the rats which swarmed among us, and found 


\section{Boobies and Penguins}

perched along its edge a dozen tiny birds. I glared at them, disbelieving my sight for a moment, then reaching out I took one in my hand, and found that it was a tired-out little swift that had thus taken refuge among us, and the fact moved me strangely.

Many such waif-visitors I have seen and in many seas, but most pathetic of all I think was one during a strong monsoon in the China Sea. The sturdy ship under a heavy press of canvas was striving to get across to Manilla from Hong Kong. It was a bleak dismal day, and I stood at the wheel, my whole attention taken up with the object of keeping the plunging vessel as near the wind as possible without shaking a shred of her straining canvas; when suddenly I became aware of a large bird that, with heavilyflapping wings, was striving hard to get on board, yet for some obscure reason was afraid to trust itself to windward, lest, apparently, it should lose command of itself and be blown against something that would do it injury. For over an hour I watched its painful labours alone, for the second mate was leaning over the break of the poop in deep meditation, and it was impossible under sea etiquette that I should call him. I cannot tell you how I suffered for that poor bird. He came so close that I knew him for a stork-I saw his long neck and beak, and his slender legs tucked closely beneath him. And I did want him safe. I almost prayed for his deliverance, he made such a gallant fight for life. But alas! he would not trust himself to windward, he would persist in coming up under the lee quarter, where the eddy from the spanker poured down strongly enough to sweep away the most powerfully winged bird that ever flew. I saw him grow weaker and weaker, still fighting vainly against qverwhelming odds, and at last in one of his swoopings 


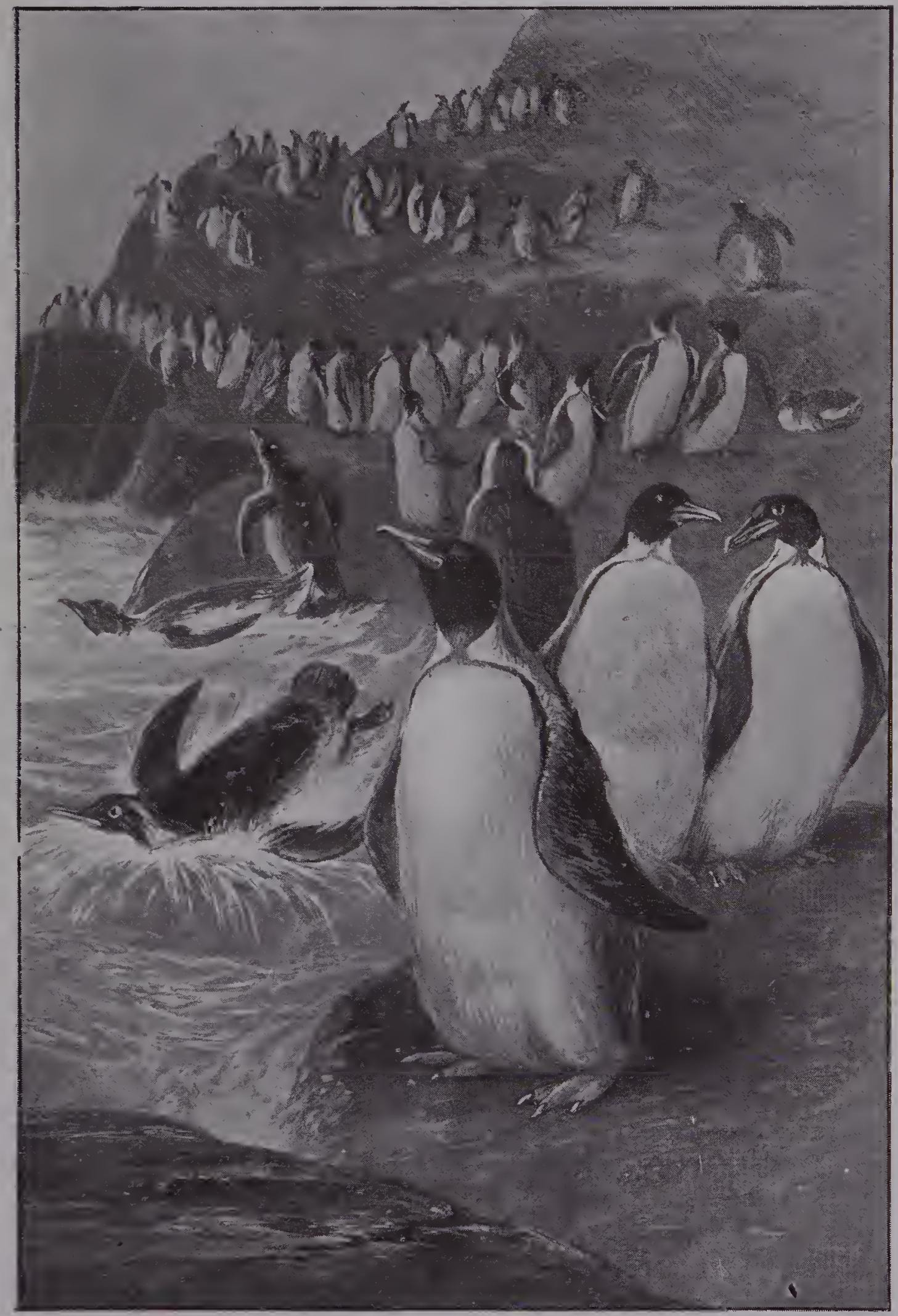

PENGUINS.

To faie p. 397. 



\section{A Quaint Sea-Citizen}

to leeward that fatal down-draught from the spanker caught him, and whirled him, a dishevelled heap of feathers, into the foaming sea sweeping past, and he was gone. I felt as if I had been watching the painful fighting for life of a dear friend, and I was scarcely comforted, when, on going into the gloomy forecastle at eight bells, I found a fluffy-feathered goat-sucker perched on the edge of my bunk, who opened the wide gape of his mouth at me, as I tenderly took him. in voiceless supplication to spare his feeble life. Need I say that his request was granted ? I fed him on cockroaches (we had plenty of those), and on entering Cavite Bay I let him go, feeling sure he would soon find a home.

But this is a digression hardly warranted by the subject. It is very necessary on account of space to pass on to the quaintest of all the feathered Deep-Sea People really entitled to the name, although they are never found at any great distance (as sailors count distance) from the shore or islands of ice. I allude to the Penguins. Their nearest counterparts in northern seas are the auks; but the latter are able to fly, the Penguin is not. It is really a sort of compromise, to all appearance, between a seal and a bird, and but for the fact that the Creator has planted it in the most lonely and inhospitable portion of the round world, would certainly long ago have been exterminated. This sad fate has befallen the great auk, whose eggs coming now and then into auction-rooms command such fabulous prices. It unfortunately inhabited places comparatively easy of access, and consequently, though it was of little value commercially and of none at all as food, it very soon became extinct when rapacious man extended his sway to the fringe of the Arctic Ocean. 


\section{Boobies and Penguins}

The Penguin, however, has been preserved from this fate, because the Antarctic regions offer little or no inducement to searchers after wealth to come to them. And in the days when seal-oil was valuable, and it was worth while to make expeditions to the barren shores of Antarctic islands in order to collect it, the Penguins were only molested for edible purposes, for they are just edible, with considerable culinary manipulation. There are several kinds of Penguins, varying in size from the diminutive Pygmy or Eudyptila minor of a few inches high, to the Emperor Penguin of as many feet. Most good museums furnish examples. But all possess the same general characteristics. First, their legs being very short and thick, and their webbed feet wide and strong, they ' sit up,' as it were. It is really standing up like a duck stretching its wings, but almost perpendicularly. And this is their normal pose. They carry their heads, with short, pointed beaks, very erect, and their flippers, for the wing in these birds is nothing but a seal flipper covered with feathers instead of fur, hanging down in a ludicrously pathetic and helpless manner. Sir John Narborough, an old navigator whose voyages make most entertaining reading, says that their appearance as he first saw them gazing at him from their rocky ledges was that of rows of school children standing very quiet with little white pinafores on. This because the closely set feathers on their breasts are white, with tinges of beautiful shades of purple and gold around the edges in the Emperors.

Their movements on shore are almost as ungainly as those of a seal; compared with them a duck or goose glides along with stately grace. For their land promenades their flippers are perfectly useless, dangling by their sides as if broken. Why they do not topple 


\section{Careful Parents}

over I cannot think, although their webbed feet are so large and wide, for their centre of gravity certainly does fall far without their bases, and great muscular effort must be necessary in order that the erect position may be preserved. Yet they manage to climb with astounding celerity the almost unscaleable icy cliffs of Antarctica, and may be seen ranged along the narrow rock-ledges in rows like vases on the shelves of a china-dealer's shop, who has no idea of picturesquely arranging his wares. In places where materials for nests are to be found they build them or lay them down (there is little constructive work possible), but where no vegetation is to be found, they just choose a slight hollow and there deposit two eggs, one always larger than the other, which has been supposed to denote difference of sex. If so, how evenly the sexes must be balanced! What has puzzled many southern voyagers is the way in which the hen Penguin, when disturbed and fearful for her eggs, will manage to convey one of them away. There is a little hollowing of the body just in front of the space between the legs, and in this it is supposed the mother carries the egg, but how she holds it there is a mystery.

The Penguin in all his varieties has a very wide range. All round the southern hemisphere, and as far north as the Galapagos Islands on the South American off-shore grounds, Penguins are to be found, and Hartwig says that Humboldt's Penguin, which is frequently found in Callao Bay, is made a household pet of by the Peruvians, who call it the pajaro nino. This he translates ' little darling bird,' but the good professor's Spanish is weak ; it only means ' baby-boy bird.' The noble Castellano is splendidly furnished with terms of endearment. At one time it seemed as if the Penguin would be exterminated on all the 


\section{Boobies and Penguins}

temperately situated islands, when once it was discovered that they were so fat that they would yield a certain quantity of saleable oil. But I rejoice to say that the danger no longer exists. On Kerguelen, the Crozets, the South Shetlands, and such places, away down to Antarctica, the poor homely Penguin has our leave to live and be happy in that state of life unto which it has pleased God to call him. And this is the more to be desired, because in the remote regions of the south the Penguin is really the only representative of land fauna. Even the seals are very few. But the Penguin congregates in his thousands, ungainly, mirth-provoking in appearance, but happy, and giving to those desolate regions the one touch of life that they need to keep them from becoming, in fact as well as in appearance, a land of death.

Now in the foregoing I have spoken, it may be thought, somewhat too slightingly of one of God's creatures because of its laughter-provoking appearance. Why should our risible faculties be excited by any creature perfectly fitted by its loving and all-wise Creator for its life-work? I do not excuse the laughter, I only note it, and quite admit that to a sparrow, for instance, if he possessed the power of laughter, a man may be the most ludicrous figure on earth, especially in a top-hat and holding up an umbrella. But though I plead guilty to having laughed at the Penguin, I have atoned. I have seen him in the water, and I laughed no longer. For that top-heavy body, that pathetically peering head, those feeble-looking flippers had all come into play.

The first time I really knew the Penguin for what he really is was when, making a composite great sircle track to New Zealand, we reached latitude 


\section{A Ballasted Bird}

401

$54^{\circ} \mathrm{S}$, and, wonder of wonders, it fell a calm. Between twelve noon and two I was at the wheel, listless and cold, and gaping all around me at sea and sky, when suddenly a Penguin popped up alongside, gave one wide-eyed stare at the unfamiliar ship, and disappeared. But he was not satisfied. Three times he came back to look, and so clear was the water that I could follow his every movement beneath it, note his exceeding beauty and grace, and-mentally apologise to him for ever having thought him ungainly or ludicrous in any way. I should add that at this time we were certainly about a thousand miles from the nearest land, which perhaps will justify my inclusion of the Penguin among the honourable company of the Deep-Sea People.

The food of the Penguin is of course fish, with which those remote seas are teeming. And this explains his amazing agility under water, for who would seize the living fish in his native element must needs move with a rapidity and a sinuous grace, to which the most splendid efforts of a human athlete are very, very slow and clumsy indeed. But like most of the seals, and for probably the same hidden digestive reasons, the Penguin thinks well to burden his belly with boulders. Sir James Ross notes that in the stomach of one of them he found ten pounds weight of quart $z$, granite, and trap. Well, the poor thing needs, no doubt at too frequently recurring times, something to impart a sense of fulness and stability to the stomach. For that organ is not only of huge size in proportion to the build of the bird, but has, in common with the seals and sharks, ay, the majority of the Deep-Sea People, a flood of digestive juices capable of dealing almost (as a sailor would say) with scupper nails. 


\section{Boobies and Penguins}

Of the domestic virtues and daily shore life of the Penguin I dare not speak, as I have no personal knowledge, and my imagination recoils at the idea of cultivating the Lares and Penates on the eternally ice-bound shores of Antarctica. 


\section{CHAPTER XXVII}

\section{THE FRIGATE BIRD}

I $\mathrm{N}$ dealing with this, the last of my Deep-Sea People,

I have unfortunately to cut across, I will not say many prevailing ideas, since the subject is not popularly known, but many quasi-scientific ideas concerning him. It is now many years since I read in a book by Michelet, the French naturalist, a long rhapsody on the Frigate Bird, most poetical, most beautiful in diction, but alas, as is so common with French scientists, pure imagination from beginning to end, without the lightest substratum of fact. In spite of my youth at the time and my innate reverence for the written word, especially in a scientific treatise, I knew that all Michelet said about the Frigate Bird was wrong; it would almost have been hyperbolical to apply it to the wandering albatross, whose powerful flight and endurance excel those of the Frigate, or Man-of-War Bird, as much as those of the latter do the powers of the sparrow.

But the pity of it is that, as in so many other cases, Michelet's absurdities have been perpetuated in our own natural histories with that serene faith in a writer's integrity manifested by Reingelder in Yates's book, as described by Kipling in his wonderful story of the German flag. Although warned by his friend repeatedly, and his attention drawn to the viperine head of the snake he held in his hand, Rein- 


\section{The Frigate Bird}

gelder, secure in his knowledge of what Yates had written of those snakes, and calm in his faith in the great authority, proceeds to examine the snake alive. $\mathrm{He}$ is bitten and dies, but with his latest breath he moans: 'Yates haf lied in brint.' Very sad, but quite understandable. A new series of books will presently deal with facts of natural history, wherein shall not appear one single statement based upon the wild romancings of the ancient naturalists, but all verified by personal observation, with the names of the authors given for easy reference.

Not that, except in the interests of truth, it matters very much whether one speaks of the Man-of-War Bird as subsisting on the wing through life and floating calmly over hundreds of leagues of ocean remote from land, or whether he be compared with the condor of the Andes for power of vision and spread of wing, or any other tale that might occur to so essentially fanciful a raconteur as the romantic Michelet. Only if we are to have facts, let them be facts; if fiction, let us understand and enjoy it as such. The Frigate Bird is wonderful enough to excite all our admiration, without one scrap of fiction being tacked on to him, elegant and withal rapacious enough to be called the eagle of the sea, although his size is so small that hawk would be the better synonym. In common with multitudes of other sailors, I have had many ample opportunities of being quite familiar with the Frigate Bird, and in what I have to say about him I shall only state that which I know from personal observation.

I first knew the Frigate Bird in the West Indies, afterwards about Ascension, and after that again all over the Gulf of Mexico and around its sandy bays. And as I read Michelet's effusion after I had 


\section{Entirely Predatory}

405

become well acquainted with the bird, I was the more eager to substantiate my first observations, and by enquiry among seamen, to get reliable information from others.

First of all, as to the oceanic range of the Frigate Bird. Three natural history books lie before me, all ostensibly based upon authentic information. One speaks of the Frigate Bird soaring over hundreds of leagues of ocean, another of its being seen four hundred leagues from land, and the third, of its calmly resting on the wing one hundred leagues from land. I have never seen a Frigate Bird more than fifty miles from shore, nor ever heard of one being seen one hundred miles from land. The latter, I am sure, is about their limit, and for the best of all reasons.

The Frigate Bird is essentially a pirate, a robber, who preys upon the earnings of honest birds. I do not mean to say that he cannot fish at all for himself, because I have seen him swoop down upon a flying-fish in the air as a hawk does upon a small bird and carry it off exultantly. But long, close watching has convinced me that alone among all the sea-birds, the Frigate Bird is unable to catch a fish under water or feed upon the water. That they can swim, their webbed feet will prove, although the webs are quite rudimentary; but I never saw one swimming, nor saw one so much as touch the water.

And in this there is to my mind something very mysterious and wonderful. It seems to me that these birds are really to the sea what hawks are to the land, and this supposition is supported by the testimony of a gentleman who has studied them very closely, Mr. Palmer, the gentleman who made the Hon. Walter Rothschild's wonderful collection of sea-birds and their eggs. He records that at 


\section{The Frigate Bird}

Laysan he many times noticed the Frigate Birds snatch a young one from a nest and eat it. Sometimes, he says, the parent bird would give chase, but the matter always ended by one or other of them eating the young bird. They would even take young birds out of the nest that were almost fully fledged. Now this is a truly diabolic characteristic, not shared by any other sea-bird, and hardly to be surpassed by the all-embracing voracity and ferocity of the vulture. There can, I think, be but little doubt that the Frigate Bird is a close relation of the pelican, but his habits certainly entitle him to be called the vulture of the sea.

But it is high time that I attempted a description of the Frigate Bird, seeing that, although of so romantic and extraordinary a character, he is little known to the great majority of readers. The body of the Frigate Bird then is, when full grown, about as large as that of a raven, but more elegantly shaped, of course, for its great power of flight. Its colour is rusty, not glossy, black, in none have I ever seen a white feather. Moreover, for some reason I do not pretend to fathom, it does not keep its plumage in good order, the feathers never lying neat and sleeked, as in other sea-birds.

Considering the size of its body, the wings of the Frigate Bird may truly be called enormous, but to speak of them as one naturalist of eminence does, as being fourteen feet from tip to tip is just a wild piece of exaggeration. I have measured a great many, but never found one that exceeded six feet in the breadth of its pinions, and it would indeed be an extraordinary specimen that attained to a wing-spread of eight feet. Even those I measured had the ends of their wings extending when folded more than halfway down the very long tail and overlapping one 


\section{A Living Balloon}

another in a particularly awkward-looking way, as if they were only meant to be kept expanded. The tail is a little longer than the body, and composed of a few strong feathers, which the bird, when on the wing, manipulates in a striking way. When hovering high in air with wings wide-spread and motionless, the tail is seen to divide in the middle, the two halves separating widely and closing again to a point, exactly as the blades of a pair of scissors do. In fact, if I had been going to give this bird a trivial name based upon his most noticeable characteristic, I think I should have called him the 'scissor-bird.' The purpose served by this peculiar movement of the tail is, I think, obvious enough; it is for steering purposes, while the wings remain immobile.

The beak, as usual with raptorial birds, is long, powerful, and hooked at the end. In colour it is a dirty white, and the edges of both mandibles are exceedingly sharp. Underneath the beak is a most curious appendage of the colour of blood, glaring against the dark background of the body. At first sight it appears as if, like the pelican, the Frigate Bird possessed a pouch for the holding of food, except that the Frigate Bird's pouch does not commence on the lower mandible or half of the beak, but just below where the beak joins the head, on the neck. Generally it is invisible, but while the bird is soaring a watcher will see the crimson netlike bag suddenly become inflated, until it looks almost portentous in its size as compared with that of the bird. There can be no doubt whatever that it is part of the creature's provision for remaining in the air so still as it does at great heights, just a bladder capable at the will of its possessor of being filled with air. And yet I cannot help thinking that there is some flaw in this argument, 


\section{The Frigate Bird}

because I feel sure that some Frigate Birds do not carry one of these bladders. In watching numbers of them I have noticed that some had it, and some had not; but whether those without it were young ones or hens I am unable to say.

Their legs are short and feeble, and although the feet are webbed the webs are only about half way down the toes. So that they are obviously meant to live practically on the wing. All naturalists agree that they are never seen swimming, certainly I have never seen one doing so, and as for walking on land it is almost an impossibility with them. They are said to roost upon the branches of trees, a most unusual thing for sea-birds to do, and I will not deny the possibility of this. But whenever I have seen them ashore, they have roosted and laid their eggs and incubated among rugged rocks, where, by the aid of their wings, they could flutter heavily from one irregularity to another. A flat surface to walk upon is useless to them. Their method of feeding again is peculiarly hawk-like and different from that of all other sea-birds.

So great an authority and careful an observer as Charles Darwin, while not stating explicitly that the Frigate Bird snatches its food from the sea-surface, says that if the offal, etc., which they desire sinks more than six or eight inches below the surface it is lost to them, as they cannot dive like any other sea-fowl. $\mathrm{He}$ also notes, as I have done myself, that such is their power of manœuvring upon the wing that they can, and do, snatch the just hatched turtles on their toddling way down the beach to the sea from the pit where they were born. To watch a Frigate Bird poised, say, a thousand feet above the sea almost motionless, except for the slow turning of the head from side to side, and the wide-eyed glance of the 


\section{The Grace of Rapine}

409

eye beneath, suddenly descend in a series of graceful curves and snatch the hapless flying-fish as he rises from the sea, is to realise how wonderful are the powers given to these birds. It is an object-lesson in perfectly graceful motion, even the snatch which secures the finny fugitive being made with such swift alertness that the eye cannot follow it, and the beholder imagines that the bird has missed its prey. Rising into the air again the fish is often dropped, probably because it was not in a good position for swallowing, and with one glorious swoop, made with apparent deliberateness, but really with tremendous swiftness, the falling fish has been caught again in the right position, and as the bird soars once more, the observer may see it being slowly degusted.

But, as I have been obliged to hint before, the main business of life for the Frigate Bird seems to be that of a robber. When the motherly boobies leave their young and fussily flap out to the fishing grounds, they do not see that floating, like black specks in the blue above, the Frigate Bird is waiting for their appearance. I use the singular, because the Frigate Bird is most unsociable. $\mathrm{He}$ is often seen in company with others of his own kind, that is in the sense of propinquity, but there is no sort of co-operation or apparent desire of association one with another. Every pirate singles out his victim, watches with keenest interest from his serene height the labouring search, imperceptibly descending to a lower plane until when at last the hard-working mother, having secured the fish, starts for home, there is a swift descent as of a black shadow, full of ease, apparently effortless, yet restrained. It is no more like the headlong plunge of the gannet than a man running is like a bird flying. 


\section{0 \\ The Frigate Bird}

Poor booby becomes conscious of the presence of her aggressor, as hasteless, fateful, he nears her ; labours hardly, frantically to escape, screams mournfully and dodges. As well try to dodge a lightning flash. The pirate is in no hurry, secure of his prey he draws nearer, nearer, until with a wild scream of rage and terror booby drops her fish and hurries to sea again for more. On the instant, the wide wings, only partially extended before, expand to their full spread, there is a tremendous curve through the air, and the falling fish is caught with ease and certainty, although sometimes only just as it is touching the water, and the graceful thief mounts again to his aerial point of vantage.

The pathos of the whole thing seems to me that it is invariably the hen boobies who are robbed, the male birds devouring their fish as soon as they secure it. But the mother needs her catch for the unfledged youngsters at home, and is consequently precluded from swallowing by the power of her maternal instinct. With such power of wing and ability to swoop upon their prey it does seem a pity that the Frigate Birds cannot confine themselves to the work of catching their own fish first hand. But then man is always of opinion that he is wiser and more merciful than God, Who hath done all things well. It is another.instance of human arrogance, which indeed cannot be trusted to interfere in any of Nature's work without doing harm that he cannot again undo.

One peculiarity attaches to the Frigate Bird which I found very pleasant. On the occasion of which I spoke in the chapter on boobies, when the men made a raid upon the boobies' nests (if their little hollows in the sand could be thus designated), I, having no boots, was compelled to stand aside or suffer grievous 



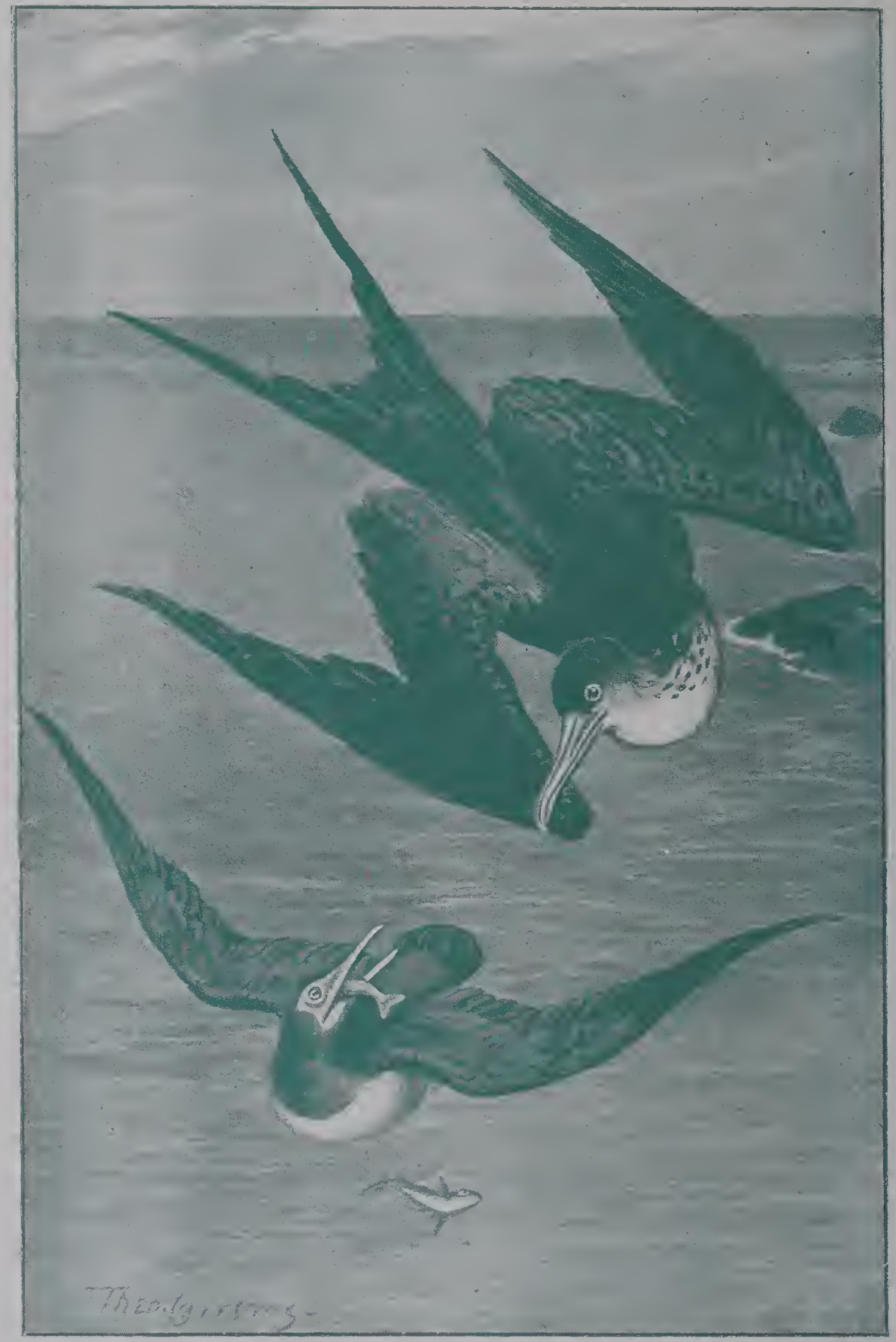

THE FRICATE FIRD AT WORK.

[To fuce t. fru. 


\section{A Desert Home}

\section{II}

harm to my feet from the powerful beaks of the birds, which they drove right and left like lance-heads at the legs and feet of their aggressors; and those of the eggs which were not addled or nearly hatched were not, I must say, at all pleasant eating, especially for me, for whom a duck's egg is too strong. So my part was to carry the eggs into camp, but finding out what they were like, I determined to absent myself from the booby-egg-hufit next morning, and have an expedition by myself.

Now the opposite side of the island upon which we were was of a totally different character to the side where we camped. The island was divided almost in half, our side being flat, sandy, and in many places sparsely covered with a straggling sort of bindweed. The other side was composed of huge masses of jagged rock hurled together in fantastic confusion, as if they had been shot out of a chariot of the gods. Over these tumbled masses I climbed with considerable pain to my feet, which only the intense curiosity I felt could allay, until suddenly I came upon a series of hollows, in each of which were two large eggs, large, that is, as a good-sized turkey's egg and much the same in appearance. I was delighted, and immediately very busy collecting these treasures until $I$ had as many as I could carry back in my cap. In the course of my researches I saw many hen birds sitting on their eggs, and while I took careful note of them, watched them in fact with an almost painful intentness, I am glad to say I never disturbed one of them.

May I say in passing that I hope my readers will appreciate the almost painful delight that all this was to me? I had never known anything before this but the sedate quiet of a London suburb, sheltered from all outside influences in my aunt's quiet home, 


\section{I 2 \\ The Frigate Bird}

and afterwards the strange nomadic existence of the London streets, and here I was in fairyland. $\mathrm{Ah}$, there was nothing of the nil admirari about me. Only one thing was wanting, the coping-stone of all real enjoyment, some one to share it with me. But in this imperfect world the ideal is always just beyond our reach, and my already great happiness was by just that much incomplete.

Another thing I noticed, the pathos of which completely reversed the severe judgment I had already passed upon these birds for what I considered their really infamous behaviour towards the poor boobies, the mournful closing-in of their lives. And as I have never since seen any sea-birds under the same conditions, the extreme characteristic impression still remains with me, not to be obliterated or even altered in any way. On many of the rock points around sat Frigate Birds, whose active life was over. Some grim disability had seized them, rendering them unable any longer to soar on high in proud superiority, monarchs of the tropical skies over the sea. There was for them no help, none of their kind came to feed them or sympathise with them, just contemptuous neglect was accorded to them. They could not be said to have any enemies; yes, perhaps one, the wonderful tenacity with which life clung to them.

Oh, the pity of it ; after such a life as theirs to sit through the bright day and the sweet night doomed irrevocably to die, but unable to reach that blessed change except through the long agony of waiting ! Their feathers hung limply down, their useless wings trailed, the joints gleaming whitely through. Those once piercing eyes were glazed, the proud heads drooped, and only the slightest motion, a sort of shudder, showed that they were conscious of my 


\section{A Welcome Contribution $4 \mathrm{I} 3$}

presence and unable to resent or avoid it. And all around them were the bones of those of their comrades who had in like manner sat and waited for death, as if to assure them that although the way was long the goal was sure. An added pathos came from the fact that coming and going birds paid not the slightest attention to these silent candidates for sympathy, much less help. But neither would they assault the helpless ones, and thus open the door of relief to them. As I stood and gazed I felt the tears streaming down, for, young as I was, the spectacle was sufficiently sad to compel all my sympathy. But it never occurred to me that I could do anything.

Very sadly I gathered up my eggs and took my way back, my spirits rising as the distance between me and the dying ones increased, until, when I reached the camp and produced my find, I was quite ready to be puffed up with a sense of my own great importance to the community. It was nearly breakfasttime, and my contribution was immediately put in hand for cooking. They were boiled, those eggs, and the first man to taste one shouted joyfully: 'Why, they're better than chickens' eggs.' I cordially endorsed his statement. They were really delicious; and what is more, there was not an addled one among them, which I attribute to the fact that I had not disturbed any of the parent birds from their sitting. The whole of them were eaten for breakfast, and afterwards, since there were no immediate duties to perform, all hands started for this new treasure field, greedily intent upon rifling it completely, not at all because we were in need of food, our store being very abundant, but-well, because I suppose man is naturally greedy.

But this raid was, in a little expected sense, 


\section{I4 The Frigate Bird}

entirely beneficent. For when the men reached the rocks and saw the monumental poses of the dying birds, they, forgetting for the moment the quest for eggs, rushed upon them with sticks, and slew until the last of the sufferers had been set free. It was done in a very brutal and thoughtless way, but the result was entirely good. Still, I felt glad even then I had no hand in it. so perfectly unmerciful may some of our most merciful restraints be.

A great gathering of eggs was made, so great that the whole of the laying ground was completely cleared of them, and also, with a wantonness for which I cannot find sufficient condemnation, the eggs upon which the mothers were sitting were also taken, none of them fit for food. So we had a grand feast of eggs for two or three days, after which we had to go without, for we could not go back to the rank eggs of the booby with the fresh, sweet taste of the Frigate Birds' eggs in our mouths. And then the men lamented, as usual too late, their extravagance. I noticed, however, that every day one or two of the men would go over to the rocks and have a busy search for a stray egg or so. Seamen are, of course, passionately fond of fresh eggs and vegetables, because they come their way so seldom. So that their voracity may perhaps be excused.

I am loth to leave the Frigate Bird, because he is the last of the Deep-Sea People with which I have to deal. And yet, somehow, I do not feel able to treat of his life in an idyllic fashion. Having stated what I know about him, I fear I have left myself little room or reason so to do. He seems to be entirely free from all those pretty traits characteristic of most other sea-birds. So destitute of natural affection are they, even for their young, that it is no uncommon 


\section{A Comic Interlude}

thing, I am told, for the hen and cock to fight furiously over the body of the poor fledgeling until it is torn to pieces, which pieces they devour with the greatest avidity. Now there are sea-birds as well as land-birds which will eat each others' eggs, but no sea-bird except the Frigate Bird will ever devour the young of even other birds, much less its own. It is a horrible practice, but one, I suppose, that has become common, owing to the birds' curious limitations in the way of food-getting.

I may just say in passing that one of the most comical natural history scenes I ever witnessed was enacted among these rocks, under my very nose almost. A bird was sitting, and for some reason I did not understand, kept looking anxiously first at me and then down by its side at a crevice in the rocks. I stepped a pace or two nearer to see what might be the matter, when the bird, apparently unable to endure my presence any longer, soared away, exposing two eggs. Immediately there appeared over the edge of the hollow in which the eggs lay the points of a row of claws, and a large crab hoisted itself hurriedly by means of them. It at once embraced one of the eggs, and turning to carry it off, tried to trundle the other one after it by covering the eggs with two of its feet. I had no stick, and a wholesome dread of the nippers of a crab like that, so I stayed where I was and watched the poacher's antics. They were irresistibly funny. He tried to look at me and where he was going at the same time; he wanted both of those eggs, and they hampered his movements. While he was cuddling the front egg, he tried to keep the other big claw ready for attack or defence, as the case presented itself; and on top of all his other troubles I could see that he expected the proprietress 


\section{I6 The Frigate Bird}

of them would be back again directly, and that she was much more to be feared than the featherless biped that was watching him. The upshot of it all was that he fell off the edge of the rock, a distance of about four feet, on to a small boulder. There was quite a smash, for when I looked after him I saw that both eggs were split, some of his claws were damaged, and there was a crack across his carapace that looked as if he would need a new one at once. But the tumble did not seem to worry him. He was making the best of the time at his disposal loading his reservoir with the contents of the eggs, while I watched him, laughing more heartily than I had done for a long time. I know that the recital of his adventures has little humour about it, but his antics were as comical as those of any clown. 


\section{CHAPTER XXVIII}

\section{SEAWEED}

$\triangle$ ND now, having come to the close of my pleasant A task, I would like to take the liberty of saying a few words upon a subject which, while not strictly within the compass of my subject, is so closely allied to it that I hope I shall be forgiven for alluding to it. It is about Seaweed. I cannot pretend to have made the growths of the sea a matter of study, although I am well aware how fascinating the subject is; but I have noticed very closely how important Seaweed is to fish, and especially the fish of the Deep Sea. Not as a matter of food, of course. With the exception of the manatees and possibly the turtle, as far as I am aware, none of the Deep-Sea People eat Seaweed, but use it for purposes of shelter and breeding.

The most important of all, as well as, I think, the most wonderful, is the beautiful sea-growth known to sailors as Gulfweed or Sargasso Weed, and to oceanologists as Fucus natans, because it floats and grows, needing no settled abiding place or root-hold. It is confined to the North Atlantic and Gulf of Mexico, and is found in greatest quantities in the vast eddy formed on the eastern side of that ocean between the Gulf Stream and the Equatorial Current. A whole series of romances might be built upon this wonderful weed-covered portion of the ocean. One or two have been based on the supposition that the enormous 


\section{$418 \quad$ Seaweed}

masses of closely knit weed are impenetrable by ships, and that by some curious centripetal force the majority of derelicts in the North Atlantic, unless destroyed. find their way into its solitudes sooner or later.

I do not believe that it is anywhere packed sufficiently closely to prevent a sailing ship getting through it, given sufficient wind. But then that part of the North Atlantic is subject to many calms and light airs, and there is seldom a breeze of sufficient strength blowing over it to enable a sailing ship to force her way through. I have several times sailed through parts of the region where the sea looked more like some vast ripe cornfield than anything else, and no matter what wind we had there were no waves, they simply could not rise because of the weed. Steamers of course give it a very wide berth, since the great masses of weed hampers a propeller dreadfully, and that too when so much more power than usual is needed to force the ship through.

The Gulfweed is, I think, the most beautiful of all Seaweeds. It is of a light golden hue, with delicate leaves and berries, both of the same colour, and bearing no resemblance in shape to the ribbon-like wrack of the coast. It certainly looks tempting enough to eat, and it may be also that, unknown to us, some of the sea creatures do eat it. But that is certainly not its primary use. In it myriads of the deep-sea fish breed, its close-knit fronds affording shelter to the young fry when hatched such as they could gain nowhere else in the sea. Not only shelter, but food perfectly suited to their immature needs. It simply swarms with life, and a bucket full of weed hauled up almost anywhere would yield a splendid population for a deep-sea aquarium.

It is the home too of myriads of crabs, which I 


\section{Submarine Forests}

do not think ever grow to any size. I certainly do not suggest that the edible crab of our coasts breeds there, and makes the long journey through midocean to get to where he may become of use to man. Especially, as the crab cannot swim through the water horizontally like other crustacea, he must have a place of some stability to walk upon, whether it be the bottom of the sea, or a frond of weed, or the planks of a derelict. No, I feel sure that the small crabs of the Gulfweed are a small species, and do not grow larger than, say, three inches across the carapace. It is the breeding place of the marvellous flying-fish, whose ova closely simulate its berries. It also affords a spawning ground for those fish such as the dolphin, which are the flying-fishes' fiercest enemies.

But as most of this has already been said in the course of preceding chapters I will pass on, albeit reluctantly, from the wonderful floating weed of the North Atlantic to the gigantic 'Kelp,' as sailors insist upon calling it, of the South Seas. Round many of those isolated mountain peaks rising from the lonely ocean plateaux two or three thousand fathoms beneath, piercing the troubled surface of the almost equally lonely sea, and towering another thousand fathoms into the air there grows an extraordinary plant. Its leaves grow to a length of six feet and a width of a foot, being in colour and consistency like wet leather. Their stems, as thick as a stout man's arm, grow to lengths unknown, but certainly over a hundred feet, grow up from the rocks beneath until they reach the surface, a veritable submarine forest whose limits are sharply defined by the depths from which the plant can reach the watersurface.

All arnund an island such a forest will grow to a 
distance off shore proportionate to the steepriess of the descent of the island's base. Within its limits no sea can rise. The fiercest waves that ever roll make no impression upon this natural breakwater, whose piles are so flexible that one may tie them in a knot, and so slender that they may be encircled by a hand clasp. Through the dim recesses of this wonderful forest the fish wander at their ease and in perfect shelter from whatever it is that fish, surface fish that is, dislike in a storm. In among its foliage they find infinite stores of food, yet in its deepest confines there is safe shelter for the young fry that would otherwise soon be annihilated. And for the navigator it often marks outlying rock points that would otherwise be passed unobserved, although it certainly prevents the sea breaking over them in a gale.

Occasionally immense masses of it a1e torn by the violence of the waves from the root-holds on the outlying fringe of the forest and take a long, long journey by the aid of the sea and current, carrying with them a microcosm of fish life to breed and multiply in some far-distant land from their original habitat. Which may account for the prevalence of precisely the same fish in places so very widely separated. Take it altogether, it is a curious plant, drawing no sustenance through its roots, but merely anchoring in obedience to some strange plant instinct for fear of being washed away, and subsisting entirely upon what it draws direct from the limpid but bitterly salt waters of the sea.

And lastly, not because of the exhaustion of the subject, but because I can only deal with deep-sea weed; that wonderfully rapid growing weed which appears as it were spontaneously in any part of the ocean where there is a solid substance to which it can 


\section{The Slimy Sea Grass}

attach itself. Kipling alludes to it in his fine poem of the Derelict:-

'South where the corals breed,

The footless floating weed

Folds me and fouls me, strake on strake upcrawling.'

Its spores must be universally diffused all over the millions of square miles of ocean. For only let a congenial surface be exposed to the action of the sea, such as a wooden plank or a bare piece of iron (it does not love the poisonous paint which is put on the bottom of steel ships or yellow metal sheathing), and in an incredibly short space of time the weed will cover it with a bright green slimy veil which, being scraped off and dried, looks like the very finest grass. So rapidly does it grow that in wet ships, as we call them, that is, vessels over whose decks the sea is almost continually washing in heavy weather, it is absolutely necessary to give the decks a good hard scrubbing every two or three days to clear off this weed growth, which is so extremely slippery as to make it dangerous to walk about the decks.

It is a very curious sight to see a ship, a sailing ship that is, that has been out a long while rolling lazily in a calm with the long dank tresses of the weed on her sides lying closely to her as she lifts, and floating out all around her as if alarmed when she plunges. But it looks exceedingly mournful upon a derelict, which naturally gathers more upon it than a vessel which is being handled, since it is obvious that the quieter its host the more rapid its rate of growth. It will there be found growing thickly all over her, even in the cabins if the sea has easy access, and as she wallows helplessly it spreads like a gloomy halo worn by the genius of despair. Only upon closer 
inspection it is seen to be somewhat enlivened by the presence of a multitude of living creatures, mostly crustacea or the spat of limpets and barnacles; and one feels that, instead of being in the presence of death, he is in the midst of abundant joyful life.

My pleasant task is over, and for all apology for its many shortcomings I can only say that I have done my best to put facts before the reader without being tedious, so that if the instruction was slender the interest might not flag. I need scarcely say that by the aid of text books it would have been quite easy to expand each one of these chapters into a book as long as the whole of them. But that, I take it, would have been to defeat the object for which I was commissioned to write these papers, and which I tried to foreshadow in the brief introduction to them. If what has been here set down has in some degree increased the reader's interest in and reverence for the work of God in places far from his every-day ken and made him feel that it is worth while to cultivate a wide and sympathetic outlook upon His world, I shall be abundantly repaid. 


\section{N D E X}

AgUlHas BaNKs, the, 64 cod at, 285

Albacore, the, I82-203 description of, 182 food of, 183 size of, 184 fishing for, 185,201 range of, 187 life-story of, $187-203$ egg-laying, 202

Albatross, 33 I-349 description of, 333 food of, 334 range of, 336 breeding of, 337 varieties of, 338 life-story of, 341-349

Alepisaurus ferox description of, 156 range of, 157 fragility of, 158

Alligator guard, 98, 110 Alopecias vulpes the foe of right whales, 45

Anchovy, 307

Antarctic Circle, the, 49

Auckland Island, 84

Auks, 397

Autobiography of a eperm whale, 1 3-38

BACALLAO, 283

Balaena australis, 48-50

Balaenoptera sibbaldii sulphureous, 64

Baleen, 46

Bank cod fishery, 281
Barbadoes, albacore at, 185 flying-fish fishery at, 230-233

Barnacles, 253

Barracouta, 3 I0-328 description of, 3 II anecdotes of, 312 fishing for, $313-328$ rapacity of, 321 life of, 323 differences in, 324 varieties of, 324

Barrier Reef, the, 52

Bartholinus, I 37

Basilaurus, 169

Basking Shark, 97

Bean, Mr., I I I, 310,325

Becke, Louis, I Io

Beluga, the, 66, 67, 70

Benthodesmus Atlanticus, 159

Beukelaer, William, 295

Bergen, receipt at, 81

Billingsgate, fish at, 278

Black Fish, 67, 7I

Bonito, the, 204, 220 description, 204 fishing for, 205, 209 size of, 207 range of, 207,210 warm-blooded, 214 parasites of, 215 as food, 217

Boobies, 386-395 description of, 387 stupidity of, 388 anecdotes of, 388 hunting for, 389 foes of, 393 
Bottle-nose Whale, 66

Bowhead Whale, 39-50

Brama, 272

Bridgetown, flying-fish at, 230

'Britannia,' 286

Burbot, 290

Burn-Murdoch, cry of, 95

By Reef and Palm, I 10

- Cachalot,' 318

Campbell Island, 84

Cape Hens, $33^{8}, 340$

Cape Pigeons, 350, 359-367

Captains Courageous, 281

Carlisle Bay, I85

Cavallé, 327

Cephalopoda, I27, 132, 134-136

Cetomimus, 155

'Challenger,' the, 146, 154, 163

Chelone imbricata, 123

Chelonophagi, 123

Chiasmodon niger, 153

Chimaras, Deep-Sea, 146-I64

Regalecus, I 52

Chiasmodon niger, 153

Rondeletia, 155

Cetomimus, 155

Simenchelys, 155

Eurypharynx, 155

Pelicanoides, 156

Saccopharymx flagellum, 156

Alepisaurus ferox, 156

Frost-fish, 158

Benthodesmus Atlanticus, 159

Lophobatilus chamaelconticeps, I 59

Tile-fish, I 59

Mancaliws Uranoscopus, 163

Corynolophus Reinhardtii, 164

Melanocetus Johnsonit, I6 4

Liocetus Murrayi, I64

Chinese fishermen, 123

Clupea alba, 305

Clupea pilchardus, 297

'Cockney, anecdote of, 226

Cod, 274-290

fecundity of, 275

food of, $276,280,286$

fishing for, 276, 281, 282

decrease of, 277
Cod-(continued)

numbers of, 280

cod-liver oil, 284

varieties of, 287

size of, 290

Corynolophus Reinhardtii, $16_{4}$

Coryphaena, 67

Coryphaena equisetus, 250

Coryphaena hippurus, 250

Crabs, 418

Crusades, tribute to, $8 \mathrm{I}$

Crustacea, tiny, 41

Cuttle-fish, food for sperm whales, 24

description of, 127-145

species of, 132

Pliny on, 136

stories of, I 37-140

fecundity of, I41

their scent of musk, 142

mode of reproduction, 143

Dactylopterus orientalis, 236

Dactylopterus volitans, 236

Dadalus, the, 176

Darwin, Charles, on frigate bird, 408

Decapods, description of, 132

range of, 133

food of, 134

Delphinidae, 66 species of, 67 foes of, 69 cannibalism of, 69

Derelict, quoted, 42 I

Dog Fish, 113

Dolphins, the, $66,238-255$

species of, 67

fins of, 69

cannibalism, 69

description of, 238

colours of, 239

scales of, 240

medial line, 240

fins of, 240

shape of, 24I

breeding-places, 241

range of, 242

fishing for, 244, 248, 254

cannibalism of, 246 


\section{Index}

Dolphins-(continued)

numbers of, 247

food of, 248

flesh of, 249

species of, 250

life of, 252

as food, 255

Drevar, Captain, on sea-serpents, I73

Dugong, 73,74

\section{Echineis remora, 273}

Edinburgh to the Antarctic, 95

Elephant Seal. See Sea Elephant.

Emysaura serpentina, I21

Engraulis, 307

Eskimo, hunters of walrus, $8 \mathbf{I}$

Eudyptila minor, 398

Eurypharynx, 155

Exocetae, I 85

Exocetus nigricans, 228

Exocetus volitans, 222

Fernando do Noronha, 99

Finback Whale, the, visit of, 60

Fishes, deep-sea, I 46-I64

Fishing, a grand day's, 326

Flat-fishes, 325

Flat-head, the, I 44

Floating island, $a, 213$

Flounders, 326

Flying-fish, 22 I-237

powers of, 22 I

$E$. volitans, 222

description of, 223

velocity of, 225

bladders of, 226

spawning place of, $2=7$

fecundity of, 228

E. nigricans, 228

fishing for, 229-233

range of, 234

numbers of, 234

French whalers, 48

Fresh-water Herring, 308

Frigate Bird, 403-416

range of, 405

character of, 405,409

description of, 4,06
Frigate Bird-(continued)

eggs of, 4I I

old birds, 412

a comic scene, 415

Frost-fish, 158

Fucus natans, 417

Fulmar Petrel, 335, 373

Gadidae, 274

Gar-fish, 26I

Giant Petrel, 335

Giant Skate, 98, 110

Globicephalus, 7 I

Gloucester, Mass., fishermen of, 282

Goode, Mr., III, 159, 179, 310, 325

Gosse, Mr., 173

Grampus, the, 67

Great Auk, 397

Greenland Whale. See Right Whale

Greenlander's tribute of walrus tusks, 8I

Grenadines, the, 117

Grien, M., 168

Groper, 327

Gulfweed, 4I7, 4I8

Günther, Dr., on sharks, 109

on deep-sea fishes, 146

on oar-fish, 352

on herring, $29 \mathrm{l}$

Gurnard, red, 235

Gurnard, sapphirine, 235

Gymnopus, I 2 I

HADDOCK, 275, 278

Hake, 275

Halibut, 325

Halicore, 73

food of, 74

Harbinger, the, II 2

Harp Seal, 90

Hartwig, Dr., on cod, 274

— on albatross, 335

- on penguins, 399

Hawk's-bill Turtle, 123

'Helen McGregor,' 316

Herring, 29I-309

trade in, 292-294, 296 
Right Whale-(contiuued)

food of, 4I

whalebone, 42

gullet of, 42

schools of, 43

sluggishness of, 43

enemies of, $43-46$

range of, 46

numbers of, 46

life of, 47

southern, 48-50

Rock Cod, 287

Rockall Bank, the, 64

Rocklings, 275, 287

Rogers, Professor, on sea-serpents, 172

Rondeletia, I 55

Rorquals, the, 59-72

solitariness of, 60

value of, 62

fishing for, 62

omnivorousness of, 64

damage done by, 65

species of, 66

speed of, 68

Ross, Sir J., 40 I

Rothschild, Hon. W. 405

'Rotomahana,' 167

SABLE IsLand, 279

Saccopharynx flagellum, 156

Saddle-back Seal, 90

'St. Helena Beef,' 253

St. Ives, pilchard fishing at, 298

St. Paul's Rocks, I90

Salmo arcticus, 280

Salmon taken to New Zealand, 321

Salting fish, 208-220

Sapphirine Gurnard, 235

Sardine, 306 decrease of, 306 range of, 307

Sargasso Sea, I9I, 227, 243

Sargasso Weed, 417

Sargassum bacciferum, 242

Saw-fish, 98, 107

Scombridae, 100-103, 128

Sea, the temperature of, III life at bottom of, I47-164
Sea Bear, 90

Sea Cow, the, 73

Sea Elephant, the, $83-89$ description of, 83 nose of, 83

numbers of, 83

hunting for, $84-88$

food of, 88

lot of, 89

Sea Horse, See Walrus.

Sea Hippopotamus, 83-89

Sea Leopard, 90

Sea Lion, 90

Sea Slug, 123

Sea Swallow, 123

Sea Turtles, I21

Sea Vitch, 77

Seals, 90-96

speed of, 90

life of, 91

abstinence of, 91

contests of, 9 I

young of, 93

range of, 94

enemies of, 94

hunting for, 95

irtelligence of, 96

Sea-serpent, the, 152

various reports of, $165-181$

Seaweed, 417-422

Seton-Thompson, Ernest, 9

Shakespeare quoted, 68

Shark, Thresher, the, foe of right whales, 45

Sharks, 97-I I 3 have no bones, 97 description of, 98 eater of human flesh, 98 appetite of, 99

life-story of, 99-106

superstitions about, $\mathrm{IO}_{4}$

fishing for, 105

young of, 105

species of, 106

voracity of, 109

range of, I I I

as food, 314

Sicily, I 84

Silliman, Professor, on sea serpents, 172 


\section{Index}

Simenchelys, 155

Sirenia, 73-76 vegetarianism of, 74

Skate, 98 , II 2

a gigantic, II 2

Skip-jack, 102, 133, 217

Sleep of animals, 363

Smith, Mr. S., 372

Snapper, 327

Snoek, 318

Solander Ground, 36, 37

Soles, 326

South Georgia, 84

South Island, 25

South Shetlands, 84

Southern Right Whale, 48-50

Sperm Whale, autobiography of, 13-38

head of, 14

school of, 14

eyes of, 14

parasites of, 20

wound of, 23

contest with cuttle-fish, 24

growth of, 25

warning of danger, 27

chase of, 27

prisoned by iceberg, 29

food of, 30

sexes of, 3 I

battles of, 32-36

boats destroyed by, 36

life of, 37

Spermaceti, 40

Spharga coriacea, 115

life-story of, II 5-I19

Sphyroena, 3 10

Sprat, the, 301

sold as sardines, 302

habits of, 303

fishing for, 303

Squalidae, 98

Squalus maximus, I80

Squid. See also Decapods. facts about, I40

Stern Pitter, 375

Stewart Island, 128

Stickleback, 97

Sting Ray, I 10

Stinker, 373
Stork at sea, 396

Stormy Petrel, 368 description of, 369 musky smell of, 370 food of, 372

life-story of, $376-385$

Strabo, 123

Stronsa, fossil in, 180

Suckers, 44, 103, 108

Sucking-fish, 273

Sulphur Bottom Whale, 64

Sunday trading, 257

Swallows at sea, 395

Swordfish, the loe of right whales, 44

description of, 263-272

fishing for, 264

powers of, 264

life-story of, $264-272$

enemies of, 267

contests of, 270

TARPON, 308

fishing for, 309

Thalassians, 121

Thresher Shark, the foe of right whales, 45

description of the shark, 98 , 108

Thynnus sarda, 217-220

Thyrsites, 310

Thyrsitops violaceus, 325

Tiger Shark, 98

Tile-fish, I 59-162

Toilers of the Sea, 127

Tonga, $5 \mathrm{I}$

Trigla cuculus, 235

Trigla hirundo, 235

Tropic Bird, 356-358

Trout taken to New Zealand, 321

Trumpeter, 327

Tunny. See Albacore

Turtle, the, I 14-126 description of, I I 4

range of, 114

life-story of, 11 5-119

egg-laying, I 8

young of, I 19

food of, 121 
Turtle-(continued)

fecundity of, 122

as food, 123

hunting for, 123

vitality of, 125

' Up a Waterspout,' I66

Vau Vau, IOg

WALRUS, THx, 77-82

description of, 77,79

food of, 79

stomach of, 79

brain of, 80

parental love, 80

foes of, 81

hunting for, 81

decreasing numbers of, 81

Weddell, Captain, 49

West Indies, the Barracouta at, 310

' West York,' 225

'Western Belle,' story of, 359

Westminster Gasette, 166

Whale Birds, 35 I

description of, 352

range of, 355
Whale, the, monarch of the deep, Io

Whale, Bottle-nose, 66

Whale, Humpback, 45, 5I-58

Whale, Killer, 43

Whale, the Right, 39-50

Whale, Rorquals, 59-72

Whale, Sperm, autobiography of 13-38

Whale, White, 66

Whale fishery, 46-48, 54-56, 62-64

Whale bone, 42

White Seal, 9, 10, 73

White Whale, 66, 67, 70

Whitebait, 305

Whiting, 275, 289

Wilson, Dr. A., 173, 174

'Wm. V. Hutchings,' I 59

Wyman, Professor, on seaserpents, 172

Xiphias, the foe of right whales, $44,107,263-272$

YARMOUTH herring fishery, 294

Yates, 403, 404

Yellow-tail, 327

Zeuglodon, 169 


\section{The "May Blossom" Series of Story Books}

1 capital series of children's stories. Good bulk, each with coloured fronitspiec and title page.

Ficap. 8vo. Cloth boards,

Harry's Holidays. ... By E. M. WATHRTORTH Amy's Secret.

Tom's First Friend. ... ... By Mrs. CoOpHr Gerty's Triumph. ... ... By M. B. MaNwhLL Jack Silver's Test.

Aunt Milly's Diamonds. ... By Ruth Lamb The Empty Jam-Pot.

The Runaways. ... ... By SIDNHY GREY Fred Kenny's Adventures.

The Boatman's Daughter. By F. M. RoBfRTsor The Children of Dickson's Farm.

Brave Dick. ... $\quad . . \quad \ldots \quad$... By Lene Tyack By Irzzia Kinge Bessie Graham's School Days. "The Bonny Susan." ... By Mary R. Jarvis What the Sea brought Janet. By ANn Scorr Chappie; or, What a Holiday Did.

Children of the City.

By A. M. BRow The Little Lamb.

The Friend for Little Children.

A Regular Little Pickle. ... By C. J. Hammiton Little Gem. … ... ... By H. H. Stook Bob and Bill. ... ... By E. EVHRETT-GrREN Arthur's Birthday Present. By ANNeTTE LySTER The Golden Street. ... ... By SIDNey GREY May Lynwood's Schooldays; a Tale of Trial and Victory. 


\section{The "Golden Sunbeam" Series of Story Books}

An up-to-date series of juvenile story books, by popular authors. Each with 80 pages of text. Coloured frontispiecs and title page. Good bulk, papor and print, and attractive binding. Small crown svo.

Two Little Princesses and a Boy.

Ben Holt's Good Name. By Mr.s. C. O'BriHN The Blind Basket Makex.

Bob's Trials and Tests. By MARY E. ROPES By FLORENCE E. BURCH
By MARY E. ROPHS
By HARRIETTE E. BURCH Jacob's Sunbeam. ... By Harre Struggle for Life. ... By Alich JANvrin Kathleen's Victory. ... By Maud Maddick The Merry Little Brownies, By M. N. Tuck Thoughtful Joe and How he Gained his Name. Dorothy's Birthday. … By B. A. THOMPsoN The Happiness of Hazelbrook.

By the Author of "Harry Blake's Trouble." Junie's White Heather. By GHRTRUDH Douguty Pete and his Father. ... ... By F. E. BURCH Bessie Mason's Victories.

By the Author of "The Travelling Sixpence."

The Strange Adventures of Willie Norman.

By C. J. HAMilion Ragged Robin. ... ... ... By M. E. ROPEs Twilight Stories. ... By Jessin Chaliacombe Jack and Gill. $\ldots . \quad \ldots \quad \ldots$ By F. E. BUrch The Lost Baby. ... ... By Finma LestiE 


\section{The "Golden Sunbeam" Series of Story Books}

Daisy's Visit. $\quad \ldots \quad$... By FAITH CHIT,TER May's Cousin. ... ... By Adhine Serghant Billy, the Acorn Gatherer. ... By F. E. BuRCH Jenny's Little Black Friend. ... By M. SALTER The One Talent. ... ... By M. S. Comrin The Great Show. ... By E. EverETT-GRrHAN Old Billy the Sweetmaker. ... By G. DoughtY The Wizard's Cave ... By Eglanton Thorne Harry's Magic Glasses. ... By C. A. MFRChR The King's Wheel. ... ... By JoHN IsabeiLL, Angel's Christmas. ... by Mrs. O. F. Waltor Little Dot. $\quad . . \quad$... By Mrs. O. F. Warto On the Face of the Flood. By Mary E. Rophs The Adventures of a Young Naturalist.

By MAY LEWIS SMITH Noel and His Star, ... ... By K. M. Johrsor A Little Crusader. ... ... By Mary E. Murray The Book of Books. ... ... By J. H. Cross Charlie Scott. Cousin Jack's Adventure. How Tilly found a Friend.

Caleb Gaye's Success. ... By Egranton Thorne Colin Courageous. ... By Mary Rowless Jarvis Arthur's Wonderful Holiday. By E. E. CARTer The Christmas Child. ... By Hesba Streition Whilst Father was Fighting. ByELEANORA H.STOOKE Friends till Dzath. ... ... By HhsBa Stration 


\section{The "Dainty Gift Book" Series for Little People}

A sery attractive series of story books for young prople.

In black-faced type, and with coloured illustrations.

Small crown 8vo, cloth.

The Adventures of Babs.

$$
\text { By MURIHE D. C. LUCAS }
$$

My Sunday Story Book. Forming a Yeár of Sundays. ... ... ... By SARAH BRINE

\section{Violet's Doll's-House.}

BY FIORHNCE STACPOOLE

The Life of a Doll.

By A. Frashr ROBHRTSON

Under the Captain. ... By MAUD MADDICK

Stories for Sunday Afternoon.

By Axwin S. Swax, and other authors. 


\section{The "Sunshine" Series of Story Books}

Popular stories for boys and girls. Crown 8vo, with coloured frontispicce and title page.

An Utwrilling Hero. ... ... By A. M. FATRHY Little Foxes, and How they were Caught. By E. FLORENCE BENSKIN Harry's Trip to India. ... By W. J. WILKINs A Strange Christmas Angel.

By REV. WALTER SHNIOR, M.A. Wallaby Hill. ... By M. BradFord Whiting An Elder Brother. ... By EGLANTON THORNE Sea Larks. $\quad . . \quad \ldots \quad$... The Daughters of the Flower Market. By G. HoLDEN PIKR A Tale of Two Stowaways. ... By C. Eilis Jasper's Old Shed, and How the Light Shone in. By A. M. COKar

The Visit to Dolby Hall, and What came of It. By MRS. KenY Lance Hernley's Holiday. ... By H. M. WILSON Little Ben, the Messenger. By Maud Maddick A Daughter of the King. By Mrs. P. Barnes Prisoners of Hope. ... By DEBORAH ALcock Effie's Temptation. ... By AnNetri Whymper Donald and his Friends. ... By SArah Gibsor Out of Cabbage Court. ... By Mary E. Rophs 


\section{The "Sunshine" Series of Story Books.}

Annie Deloraine's Aunt. ... By E. A. BLANd A Fortunate Exíle. $\quad . . \quad$... By LILY Watson Alison's Ambition. ... ... By Mary Hampden Arthur Ranyard's Training. By EMMa LESLII Bravely Borne. $\quad \ldots \quad \ldots \quad \ldots \quad$ By L. C. SILKE Harry Lester. $\quad \ldots \quad \ldots \quad \ldots \quad$ By ALICE LANG Geordie's Tryst. $\quad \ldots \quad \ldots \quad$ By Mrs. MII,NE RAE Edgar's Pride. $\quad$... $\quad \ldots$ By MaUd Maddick Real Friends. ... By Margaret J. M. Boliand Standing the Test. ... By J. Macdonald OxLey The Boy who Never Lost a Chance.

BY ANNETTE C. LYSTER Christy's Mission. ... ... By Lena Tyack Esther's Triumph. $\quad \ldots \quad$... By Emma LeELIE Tony's Neighbours. ... ... By M. B. ManweI, Heedless Hetty. ... ... By AnNetre Lyster Crookside Lads. ... ... ... By A. M. CORER Little Miss Rosenburgh. ... By Crona Temple Darcy, the Young Acrobat. Why Should I? ... ... By EmMa S. PRATT That Scholarship Boy. ... By EMma Lesirin 


\section{The "Sunshine" Series of Story Books}

A Boy of Red River. By J. Macdonald OxLEY Leo's Story. $\quad \ldots \quad \ldots \quad \ldots$ By JENKIN JONES The Captain of the Eleven.

By K. Skirley PLANT Lilla's Experiment. $\ldots . \quad \ldots$ By C. M. CLARRH Wilful Madge Marshal. ... By Francis SwEyn Joe Harman's Experiences.

By GRORGH E. SARGRN'T

Two Little Fortune Hunters.

BY FLORENCE E. BURCH

Schoolboy Courage and its Reward.

By C. F. Higginson

Three Little Great Ladies. By W. Percy Smith Lost, Stolen, or Strayed. By Jrssin ArMstrong Dad's Dorothy. ... ... By M. B. ManwelL Cinderella's Prince. By Marian Isaber Hurreili Two Brave Boys and the Wrong Twin.

By MARY E. ROPAS Saved from the Wreck. ... By JAMES NUNN Daisy's Knight. ... ... By M. B. MANWELI Maggie's Message. ... ... By Emma LesLIE Nobody Cares. ... ... By Crona TEMPLE The Autobiography of a Missionary Box. BY ANNETTE WHYMPER Adaora. $\quad \ldots \quad \ldots \quad \ldots \quad \ldots \quad$ By MARY E. BIRD 


\section{The "Sunshine Series" of Story Books.}

Megsy's Influence. ... ... By M. I. HURRHLI Benedicta's Stranger. ... By K. E. VHRNHAM Mrs. Bird's Neighbours. ... By C. M. HaLLETT Leila's Choice. ... ... By Mary HampdeN The Treasure Finders. By Mary Rowlets Jarvis Bet and Ben. ... ... ... By Amy Whipple How Little Bessie kept the Wolf from the Door. By Mrs. COATES

Next-door Neighbours. ‥ By AGNes GIBERNE Joyce's Little Maid. ... By NeLLIH Corwwali, Always a Knight. ... ... By W. R. CAMPEY Audrey's Offering. ... ... By LeNA TYack When Daddy's Ship Comes In. By B. M. PuRSER The Making of Teddy. ... By Eva Jamison His Guiding Star. By Marian ISABEL HURRELIL Jock, The Shrimper, and other Stories.

Dorothy, ... ... ... ... By M. M. POLLARD Kitty and Toddles. ... By Mrs. Philip Barness Led into Light. ... ... ... By Lucy TayLor Liz's Shepherd. ... ... By Frances MarshaLL Four Little Kind Hearts. ... By AMY GREY Plucky Roy, ... ... , ... By Lyeia Philitiss Granfer's Wonderful Garden. By E. H. SToorge 


\section{The "Advance" Series}

A popular series of excellent valus. Crown svo. With coloured frontispieco, of good bulk, and attractively bound in decorative cloth.

The Last House in London. By C. TEMrL Taken by Storm. ... ... By E. A. BLAND Rights and Wrongs. ... ... By S. S. Pugr From Bondage to Freedom. ву Емма LвsцIn A Bunch of Roses. By C. Lockhar't Gordon At the Sign of the "Blue Boar." By EMma Lasim

Marching Orders. $\quad \ldots \quad \ldots \quad$ By L. TAYLoR Miss Monteith's Riddle. By M. S. Comrin The Minister's Family. ... By L. RaDrord The Prisoner of Prague. By Emma LesLife In the Toils of the Luddites. By A. Cor,Becr Free to Serve. ... By Evilyn R. Garratr How Dick found his Sea Legs.

By Mary E. PALGRAVx Not Peace but a Sword. By C. R. Wynne Alice Barlow's Trust. ... By G. E. Sargenr The Master's Likeness. By JostepH JoHnson Tessie's Trust. ... ... By Amy Whipple A Child Without a Name.

BY EVELYN EVHRHTT-GRHHN 


\section{The "Advance" Series}

Cynthia's Choice. ... ву EмiLy M. Roвinson David and Jonathan. ... By Jurra Hack The Sunny Side of the Street.

BY EVELYN EVERETT-GREEN

In London Fields. ... By Egr,ANTon Thorne The Secret Room. ... By L. Pocrimseton Tregg's Triumph. ... By E. EVERETT-GREEN The Search for Molly Marling. By E. P. Whaver The School Mistress of Haven's End. By F. E. OVERTON Between Two Opinions. By F. M. PaLgrave The Great Salterns. ... By SARAh Doudney The Hill of Fire. ... By NeLLIE Cornwali Phil's Hero; or, A Street Arab's Resolve. By C. E. Baron

Richard Maynard, and Other Stories. By A. B. COOPER John Strong. $\quad \ldots \quad \ldots \quad$ By OLd HUMPHREY Pomponia. $\quad \ldots \quad \ldots \quad$ By MRg. J. B. WEBB Sunflowers. A Story of To-day. By G. C. GEDGE Norman's Inheritance.

By F. C, KFNYON \& R, G. SOANS 


\section{The "Advance" Series}

Little Robin Gray. ... By EDrry C. Kanyos

Dora Murray's Ideal, and How it came to Her. ... ... ... By M. C. FRASER

The Girl with a Talent. By Mary HaMpdEN Through Ways Unknown. By A. F. WILBon Fighting Through. … By H. L. BRDFORD The King's Sword. By HELEN H. WaTSON Not like Other Folks. By Jessie Armstrong Faithful but not Famous. By Emsa LasLIs The Slippery Ford. By Mrs. C. M. CtaRKE Sundial Court. ... ... By LuCY TAYLOR Janet Darney's Story. Br SARAH DoudNEY Wavie: The Foundling of Glenderg.

By CRONA TEMPLA

Filling Her Place. By FLoRENCE E. BURCB Clarice Egerton's Life Story.

BY ANNETTE LYSTER

Langdon Manor. ... ... By G. E. SARGENT Christie's Next Things. By E. M. Kenney Friends Worth Keeping.

Chords that were Broken. By W. H. Hardang How John Dale let his Light Shine. 


\section{"Buttercups \& Daisies" Series}

A series of entertaining story books for quite young readers. Crown $8 v 0$, illustrated, and attractively bound.

Ivy's Dream. ... By HarrietTe E. BuRch Corrie. A Christmas Story. ... By RUTh LYNN A Waif and a Welcome.

Five Little Birdies. ... By AGNes GIBERNE Zach and Debby. By MABel QUirLer-Couch Willie and Lucy at the Seaside.

Sugar Candy. ... By KATHLEEN M. BHIL The Sea Baby. ... ... ву Амy Whipple $\mathrm{He}$, She and It. A Story for Children.

By KaTE MELLERSH The Story of Jessie. By MABEI QUILLER-Couch Netta, Two Boys and a Bird.

Better than Play. By Mabil Quiriter-Couch Enid's Ugly Duckling.

By H. L. BEDFORD AND E. EVERETT-GREEN

The Children of Brookfield Hall.

By LYDIA PHILIIPS Jean, the Joy Bringer. By EsTHER E. ENOCK The $T$ wins that did not Pair.

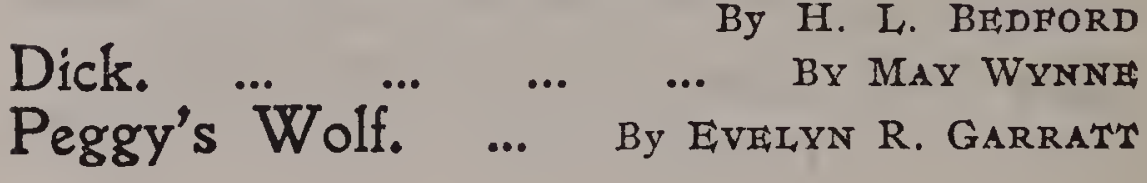




\section{The "Good Shepherd" Series}

Large books in large type. Each with coloured pictures or coloured frontispiece and many other illustrations.

Imp. 800. In coloured picture boards.

The Children of the Bible.

The Children's Natural History.

By G. A. Hutchison \& ThHOdore Wood, F.E.S.

Easy Steps for Little Folks. By F. M. Hor,Mes

The Good Shepherd.

The Life of the Saviour for Children.

Little Harry's First Journeys. Travels by 'Train, Tram, and Steamboat. ... By F. M. Hol,Mis

Little Harry at the Seaside. By F. M. HOLMES

Pictures for Little Toddlers. By F. M. Holmes

The Shepherd King.

The Life of David for Children.

Tales Told in the Nursery. The Child's Book of Common Things. By L. I. \& E. M. TONGE

Tales of Bible Heroes.

True Stories for the Little Ones.

By L. I. \& E. M. TONGE

Walks and Talks in the Zoo.

BY HENRY SCHERREN, F.Z.S.

Jessica's First Prayer. Large type edition.

By HASBA STRHTTON

Christie's Old Organ. Large type edition.

By Mrs. O. F. Walton

Teddy's Button. Large type edition.

By AMY LA FeUvRA 


\section{The "Good Shepherd" Series}

Probable Sons. Large type edition.

By AMY LE FHUVRE

Angel's Christmas and Little Dot.

Large type edition. By Mrs. O. F. Walton

Letters to my Children from the Holy Land.

By HENRY A. HARPER

Eric's Good News. Large type edition.

By AMY LE FeUtret

Little Faith; or, The Child of the Toy-Stall. Large type edition. By MRs. O. F. WAITON

Our Pets and Companions.

BY MARY KeMmbie MARTIN

Little Harry in London. ... By F. M. HoLMES A Gift for a Pet. MIy Picture Story Book. Bible Pictures for Our Pets. (Old Testament). Scripture Pictures for Little People. (New Testament).

Our Little One's Picture Book.

Simple Stories and Pretty Pictures.

Sunny Hours. Joy Pictures. The Little Pet. My Little Friend. Cosy Nook Pictures. The Five Gardens. ... By Hope ALIWARD Frolics in Spring and Summer. By L. M. OYLER Frolics in Autumn and Winter. By L. M. OYLER Pretty Stories and Simple Rhymes.

BY AMY WHIPPLE

Fireside and Bedtime Rhymes and Stories. 


\section{'Pictures that Teach'}

By Harold Copping. Size of picture 8 ins. $\times 6$ ins. Size of mount $11 \frac{1}{1}$ ins. $\times 8 \frac{7}{8}$ ins.

Artistically mounted, with cord for hanging.

4d. net each. Unmounted 1 d. net each.

The Prodigal Bon.

Jesus Blessing Little Children.

The Little Chlld Sot in the Midst.

The Sermon on the Mount.

The Good Bamaritan.

The Healing of the Leper.

The Flight Into Egypt.

The Bower.

The Fooliah Yirgins.

The Call of Indrex and Peter.

Bllnd Bartimøus.

The Great Inyitation.

The Lost Plece of silver.

The Rich Man and Lazarus.

The Pharisec and the Publícan.

The Ascention.

The Raising of Lazarus.

Peter and John at the Beautiful Gate.

Noah Building His Nltar. Hagar and Ishmael. Abraham and Isaac. Rebekah at the Well.
Jacob and Esau.

The Selling of Joseph.

Joseph Known to his Brethren.

The Finding of Hoses.

The Imiting of the Rock.

The Brazen 8erpent.

Ruth and Nsomi.

Bamuel and Ell.

Daxid summoned before Samuel.

Elijah and Lhab.

The Finding of the Book.

Daniel in the Den of Llons.

Xdam and EYO.

Caln and Abel.

Jecob's Yor.

The Burning Bush.

Moses on Pligah.

The Fate of the

Canaanite Bings.

By the Riyer, of Babylon.

Kehemiah's Midnlght Buryey.

The Annunciation.

The shepherds of Bethlehem. 


\section{'Pictures that Teach'}

By Harold Copping. Size of picture $8 \frac{8}{8}$ ins. $\times 6$ ins. Size of mount $11 \frac{8}{8}$ ins. $\times 87$ ins.

Artistically mounted, with cord for hanging.

4d. net each. Unmounted 1d, net each.

John the Baptist.

The Temptation.

The Miracle of the

Loryes and Fisher.

The Question of the Badducees.

The Well of Bychar.

Martha and Mary.

The Transfiguration.

Gethsemane.

It the Cross.

Mary Magdalene at the Sepulchre.

The Walk to Emmaus.

The Barren Figtree.

The Death of Stephen.

8t. Paul led Into

Damasour.

The Hessengers to Peter.

8t. Paul at Lystra.

8t. Paul and the Pythoness.

8t. Paul and the Jailer.

Bt. Paul at Jerusalem.

Bt. Paul at Melita.

Bt. Paul' Escape from Damascus.

Jacob before Pharaoh.

The Retarn of the Sples.
Baul and the Witch.

When the King sax Esther.

Isalah and the

Hescongers.

The Captiye of Babylon.

The Good Shepherd.

Come unto Me.

Christ in the Temple.

Christ Washing the

Disciples' Foet.

The Entry into Jerusalem.

The Daughter of Jairus.

The Lost 8heep.

The Centurion.

The Rich Young Ruler.

The Wido of Nain.

The Woman of Canaan.

st. Paul before Felix.

8t. Paul Stoned and loft for Dead.

The Conversion of Lydia.

Bar-Jesus or Elymas.

Prophecy of Agabus.

The Fall of Eutychus.

The Last Imprisonment of St. Paul.

[CATALOGUH No. 9. 



A39003

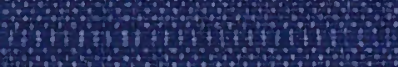

